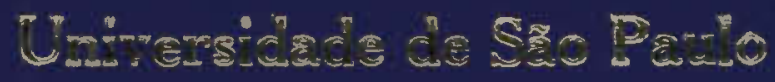

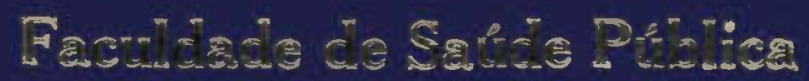

\section{Análise de Risco Ambiental de Processo Siderúrgico}

\author{
Norival Percira
}

\author{
Tese apresentada as Programa ce Pús- \\ Graduapầ em Saide Fublica para obtençâo \\ do thulo de Oeuto ent Sacje Fublica. \\ Area de Concentrap̧azo: Sacids Amb sntal \\ Orientadora: Prola. Dra. Helena A. dos S. Lima Perero
}

\section{S:o Paulo 1988}



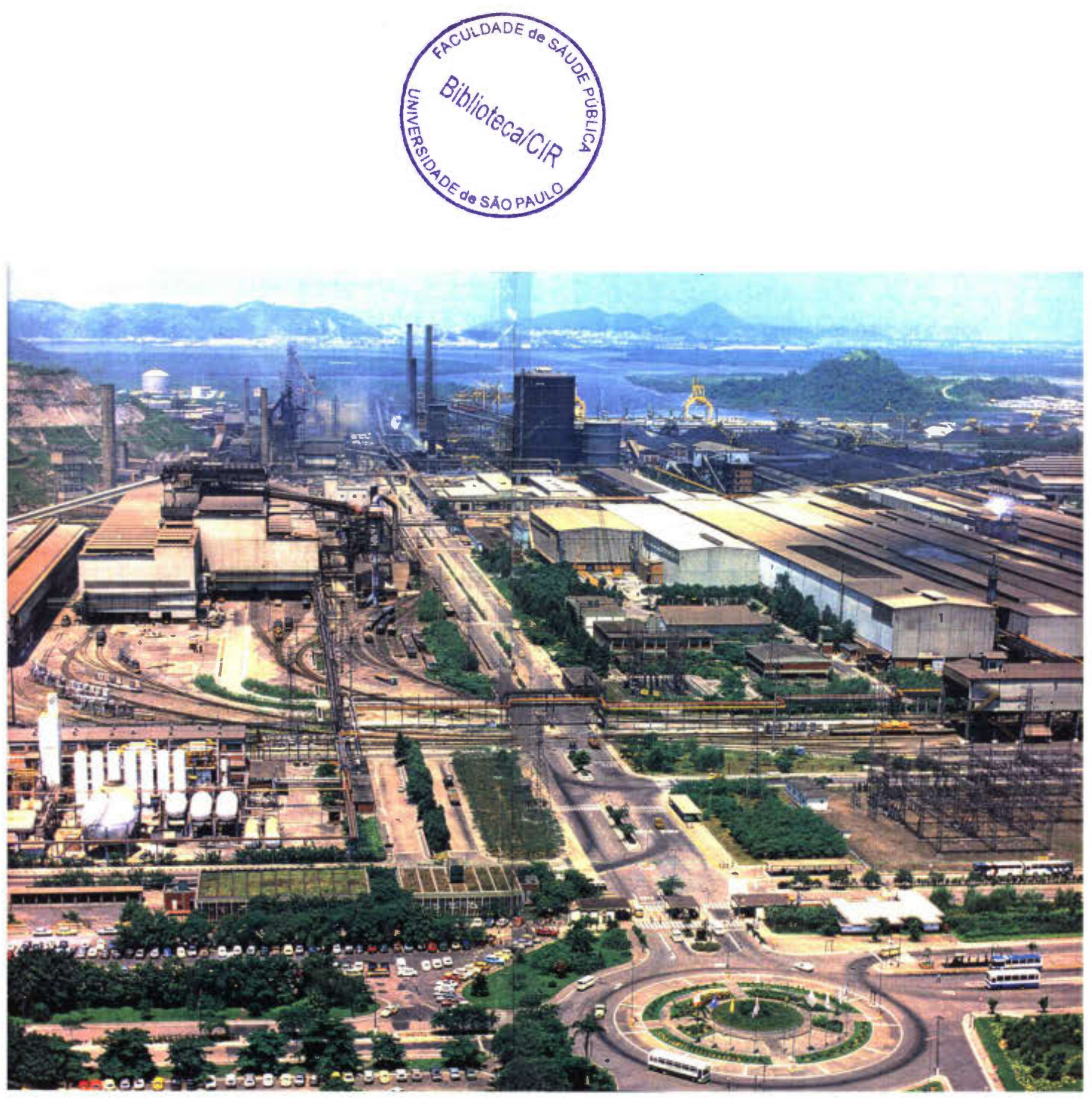


\section{Agradecimentos}

A realização deste trabalho teve a colaboração direta e indireta de muitas pessoas queridas, para as quais é uma alegria poder expressar minha gratidão.

À Professora Doutora Helena Apparecida dos Santos Lima Pereira, minha orientadora, pelo apoio, amizade e habilidade em dirigir e aperfeiçoar este trabalho.

Ao Professor Doutor Aristides Almeida Rocha, amigo e mestre, pelo incentivo e ensinamentos durante estes anos todos.

Ao Professor Doutor Carlos Celso do Amaral e Silva, pelas orientações relativas ao desenvolvimento do tema proposto.

Ao Engenheiro José Antônio Costa Perez pelo incentivo e apoio desde os primeiros passos dados para o desenvolvimento deste trabalho.

Ao amigo Walter Rocha pelo apoio e consideração demonstrada.

Ao Ricardo Rodrigues Serpa, Gerente da Divisão de Tecnologia de Riscos Ambientais da CETESB, pelo interesse e apoio dispensados, e ao Edson Haddad e à Vera, da mesma Divisão, que também colaboraram no fornecimento de dados e informações.

Ao Hélvio Aventurato, Gerente do Setor de Atendimento a Emergências, da CETESB, pela consideração e apoio fornecido.

Ao pessoal da biblioteca da CETESB, especialmente à sra. Sonia Theresinha Barbosa, pela valiosa colaboração.

Aos colegas Rubens Born, Irismar Naves Mendes (ABEMA, de Brasília), Hidely Grassi Rizzo (Depto. de Gestão Ambiental do MMA) e João Alberto Pinheiro Jr. (IAP/PR) e Órgãos Estaduais de Meio Ambiente, Secretarias de Estado e Procuradorias da República, pelo interesse e fornecimento de material técnico e legal.

Ao CNPq pela Bolsa fornecida em 1994.

Aos meus filhos Rodrigo e Caio Cesar e a meu pai pelos incentivos dados. 
Dedicatória

À Denise, esposa e amiga, pois sem o seu apoio e incentivo este trabalho năo teria sido começado, desenvolvido e, principalmente, concluído. 


\begin{abstract}
Resumo
O processo industrial é composto de várias atividades e operações que podem vir a gerar acidentes que, se efetivados, poderão levar a indústria a situações catastróficas, decorrentes de perdas patrimoniais ou de produtos, lesões graves, ou morte de seres humanos, bem como danos severos ao meio ambiente. Para identificar, avaliar e gerenciar esses eventos indesejáveis, foram desenvolvidas técnicas de análise do processo industrial que têm permitido aos administradores conhecer e reduzir ou eliminar essas probabilidades. Entretanto, as análises de risco de processo foram elaboradas apenas para identificar e controlar os riscos de acidentes com efeitos sobre o patrimônio ou sobre a segurança e saúde humanas.
\end{abstract}

Neste trabalho, apresentam-se as principais técnicas de análise de risco disponiveis, selecionando-se três que mais se aplicam às necessidades de classificação, identificação das hipóteses de risco e avaliação das conseqüências da ocorrência dos eventos identificados. A essas técnicas são propostas modificaçōes, que introduzem a variável meio ambiente nas análises selecionadas. As modificações incluem o desenvolvimento de uma terminologia apropriada e a definição de uma graduação dos riscos em função do meio afetado. O trabalho relaciona ainda o tipo de substância perigosa identificada no processo industrial com os constituintes do meio que pode ser afetado, assim como as conseqüências de um acidente com essas substâncias. As técnicas modificadas (CATBRAS, Análise Preliminar de Risco - APR e Análise de Árvore de Eventos - AAE) foram utilizadas para analisar os riscos do processo siderúrgico, a fim de avaliar sua aplicabilidade. Os resultados obtidos permitem recomendar o uso dessas técnicas para a análise de risco ambiental (ARA) de um processo industrial. A identificação da probabilidade de acidentes, a avaliação de suas conseqüências para o meio ambiente e a adoção de controles possibilitam ao empreendedor apresentar um Programa de Gerenciamento de Risco Ambiental e estabelecer um eficiente sistema de Comunicaçăo de Riscos com a sociedade, sob a influência das atividades da empresa. No trabalho estima-se, também, o custo para a realização do processo de análise de risco ambiental (ARA) que, embora possa ser considerado alto, certamente será menor que os custos decorrentes do ressarcimento de danos (patrimoniais e ambientais ou à saúde humana).

Embora de grande importância para o reconhecimento e controle de operações que possam gerar acidentes com substâncias perigosas, as legislações ambientais, federal ou estaduais, não são claras ou específicas quanto à exigência da ARA. Após a avaliação das legislaçōes (internacional, federal e estaduais) disponiveis, recomenda-se que essas legislações incluam, no procedimento de licenciamento ambiental, a exigência clara e específica de apresentação da análise de risco ambiental, incluindo a identificação das hipóteses de acidentes e a avaliação das conseqüências ambientais desses acidentes. 


\begin{abstract}
Industrial processes are complex and comprise several activities and operations that may lead to accidents. These may be catastrophic, causing harm to properties or loss of production and environmental hazards, including human deaths. Several methods were developed to identify, evaluate and control these accidents, which makes it possible the minimization of such risks. However, risk analysis of industrial processes were developed to identify and control only the risks which may affect properties or those threatening the human safety and health.

In this work the most used risk analysis procedures are discussed. Three procedures were chosen as the most appropriate to be adapted to the environmental approach. These methods were adapted in order to include: an appropriate terminology; the definition of a risk hierarchy in relation to the affected environment; the relationship between hazardous substances and the environmental components that must be taken into consideration, and the effects of an accident caused by such substances.
\end{abstract}

The adapted methods were evaluated through a case study, the results obtained allowing the recommendation of these methods in environmental risk analyses of industrial processes, specially for steel industries. The identification of the probability of an accident, the evaluation of its environmental effects and control procedures enable managers to create an Environmental Risk Management Program, as well as an efficient risk communication plan. The cost of the environmental risk analysis was also estimated; although high, it will certainly be lower than any expenses derived from the compensation of losses of properties and environmental or human health hazards.

Environmental laws and regulations are important to manage and control hazandous substances. However, federal and state laws do not specifically require environmental risk analysis. Therefore, this work suggests the inclusion of environmental risk analysis as one of the requirements for environmental licenses and permits. This component (the environmental risk analysis) should include the identification of hypotheses of accidents and the evaluation of the environmental effects caused by such accidents. 
Agradecimentos

Resumo

iii

Abstract

iv

Sumário

Lista de Tabelas

Lista de Figuras

1. INTRODUÇÃO

1.1. A indústria siderúrgica e os riscos para o meio ambiente

1.2. Estudo de impacto ambiental $X$ análise de risco ambiental ..................................... 7

1.3. A análise de risco ambiental e a legislação .................................................... 8

1.4. A análise de risco ambiental e o custo de sua realização ......................................... 9

1.5. Objetivos

2. METODOLOGIA E ESTRUTURA DA TESE

2.1. Elaboração de uma proposta de metodologia adequada para a execução de uma análise de risco ambiental, para o processo siderúrgico

2.2. Proposta de alteração na legislação ambiental, de forma a abranger a análise de risco ambiental

2.3. Quantificação dos custos relativos incidentes sobre as empresas siderúrgicas, decorrentes da análise e gerenciamento de risco ambiental

3. PROPOSTA DE METODOLOGIA PARA EXECUÇÃO DE ANÁLISE DE RISCO AMBIENTAL DE PROCESSO SIDERÚRGICO

3.1. Conceitos básicos

3.2. Processo de obtenção do aço ...

3.3. Os riscos do processo siderúrgico

3.3.1. Principais processos que apresentam risco de acidentes com conseqüências ambientais

3.3.2. Substâncias envolvidas nos processos siderúrgicos que apresentam risco de acidentes

3.3.3. Caracterização e classificação das substâncias perigosas normalmente presentes em uma unidade siderúrgica

3.3.4. Identificação de fonte de dados de acidentes, na indústria siderúrgica nacional

3.3.5. Histórico de acidentes

3.3.6. Principais riscos identificados em banco de dados ...................................... 37

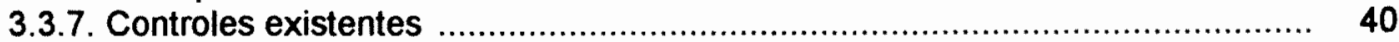

3.4. Principais técnicas de análise de risco disponiveis para incorporação à análise de risco ambiental

3.4.1. Priorização rápida ou identificação do grau de risco ........................................

3.4.2. Definição das hipóteses de acidentes ou análises de risco qualitativas ......... 48

3.4.2.1. Técnicas simples de identificação de risco ....................................... 49

3.4.2.2. Análise Preliminar de Riscos - APR ............................................ 49

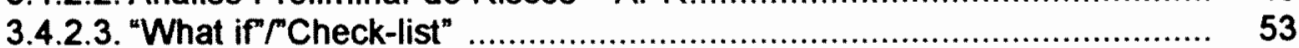

3.4.2.4. Identificação de perigos e estudos de operabilidade - HAZOP ........... 54

3.4.2.5. Análise de modos de falhas e efeitos - AMFE ............................. 55

3.4.2.6. Análise de árvore de eventos - AAE .......................................... 55

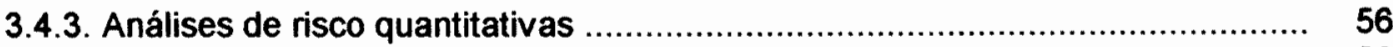

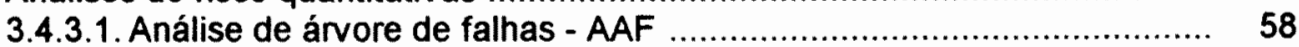

3.4.3.2. Avaliação de conseqüências ................................................... 59

3.4.3.3. Estimativa de freqüência ...................................................... 59

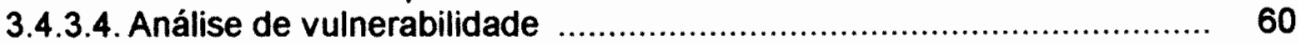

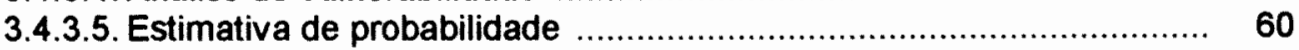

3.5. Proposta de metodologia apropriada para a análise de risco ambiental..................... 63 
3.5.1. Identificação do grau de risco do empreendimento ..................................... 64

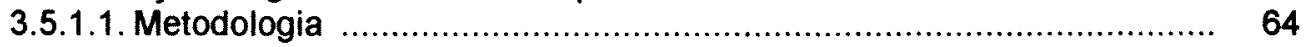

3.5.1.2. Análise da metodologia CATBRAS ........................................... 69

3.5.1.3. Proposta de aprimoramento na metodologia CATBRAS .................. 70

3.5.2. Definição das hipóteses de acidentes ............................................................. $\quad 74$

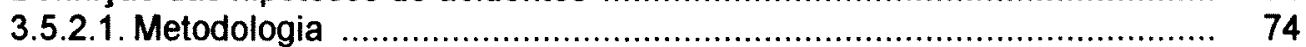

3.5.2.2. Análise da metodologia da APR ............................................... 75

3.5.2.3. Proposta de aprimoramento da Avaliaçăo Preliminar de Risco -

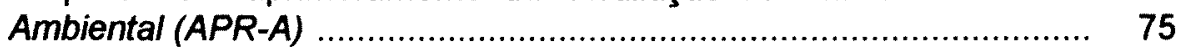

3.5.3. Avaliação das conseqüências das hipóteses de acidentes definidas .............. 80

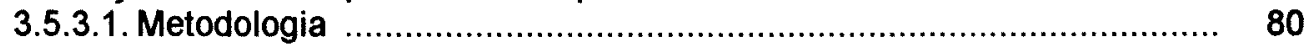

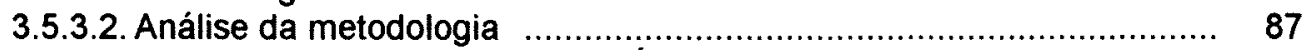

3.5.3.3. Proposta de aprimoramento da Árvore de Eventos - Ambiental (AE-A) 87

3.6. Aplicação prática da análise de risco ambiental a um processo siderúrgico............... 99

3.6.1. Identificação do grau de risco do empreendimento ...................................... 100

3.6.2. Definição das hipóteses de acidentes ................................................... 112

3.6.3. Avaliação das hipóteses de acidentes definidas ........................................ 120

3.6.4. Considerações ................................................................................... 122

4. PROPOSTA DE INCLUSÃO DA ANÁLISE DE RISCO AMBIENTAL NA LEGISLAÇÃO .. 128

4.1. A legislação ambiental internacional ................................................................. 128

4.2. A legislação ambiental nacional .................................................................... 129

4.2.1. Responsabilidade civil por danos ao meio ambiente ................................... 129

4.2.2. Análise da legislação ambiental brasileira ............................................... 131

4.2.3. Legislações estaduais ......................................................................... 132

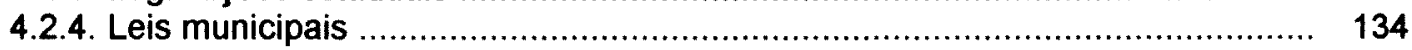

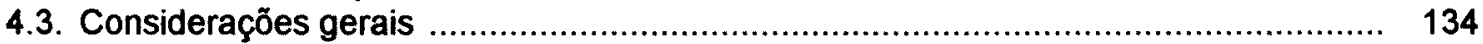

4.4. Subsídios para proposição de mudanças na legislação …….............................. 135

5. ESTIMATIVA DE CUSTOS DA ANÁLISE DE RISCO AMBIENTAL DE PROCESSO SIDERÚRGICO

5.1. O processo de análise de risco ambiental .................................................... 138

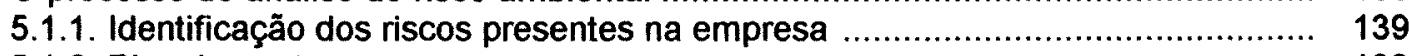

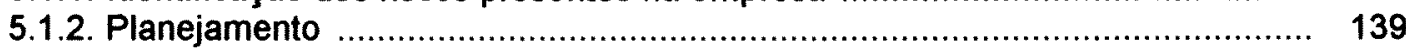

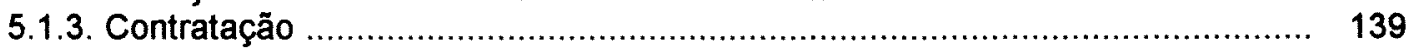

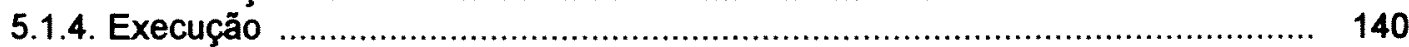

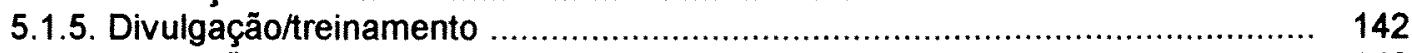

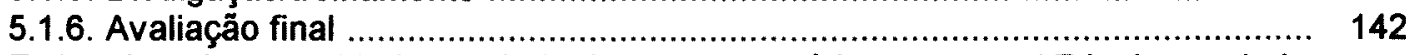

5.2. Estimativa da quantidade total de horas necessárias para a ARA de um dado sistema, das unidades de uma indústria siderúrgica ........................................... 142

5.3. Considerações ................................................................................ 144

6. O GERENCIAMENTO E A COMUNICAÇÃO DE RISCOS AMBIENTAIS ...................... 145

6.1. O gerenciamento dos riscos ambientais ........................................................ 145

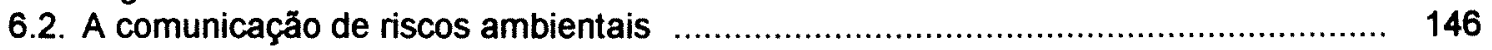

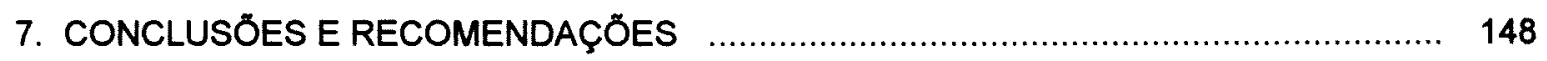

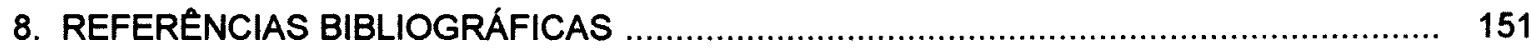


Tabela 1. Principais técnicas relativas a análise de risco, consideradas neste trabalho

Tabela 2. Resumo dos passos da aplicação da ARA

Tabela 3. Principais processos que apresentam risco de acidentes com conseqüências ambientais

Tabela 4. Fatores físicos e químicos que atuam sobre as vias de exposição e os mecanismos de transporte

Tabela 5. Relação das principais substâncias, produtos e residuos industriais, classificados como perigosos (potencial de causar algum dano), normalmente presentes numa unidade siderúrgica.

Tabela 6. Caracterização e classificação das substâncias presentes numa usina siderúrgica

Tabela 7. Dados obtidos no CADAC da CETESB, atualizado até outubro de $1997 \ldots \ldots$

Tabela 8. Relação das substâncias envolvidas nos acidentes registrados no CADAC CETESB, atualizado até outubro de 1997

Tabela 9. Dados de acidentes do banco de dados SONATA, de 1956 a 1987 , envolvendo a indústria siderúrgica

Tabela 10. Surgimento da avaliação quantitativa de risco: marcos selecionados - EUA

Tabela 11. Principais tipos de riscos

Tabela 12. Principais técnicas de priorização rápida para acidentes maiores

Tabela 13. Principais objetivos das técnicas simples de identificação de risco

Tabela 14. Principais objetivos das técnicas de análise de risco qualitativas

Tabela 15. Principais objetivos das técnicas quantitativas de avaliação de risco

Tabela 16. Principais componentes geradores de riscos ecológicos

Tabela 17. Meios físicos expostos a produtos químicos

Tabela 18. Parâmetros de definição dos níveis de periculosidade

Tabela 19. Proposta de graduação dos riscos relativos à sensibilidade da área circunvizinha a um empreendimento

Tabela 20. Categorias de riscos, conforme proposto por FANTAZZINI \& FARBER (1989)

Tabela 21. Proposta de adequação de terminologia e graduação do risco ambiental ....

Tabela 22. Categorias de risco ambiental, conforme proposta de aprimoramento da APR

Tabela 23. Descrição dos efeitos ambientais indicados nas AE-A das figuras 22 a $24 \ldots$ 
Tabela 24. Comparação dos resultados obtidos entre a APR original e a APR-A proposta, para a usina siderúrgica considerada

Tabela 25. Priorização das unidades frente à classe de risco identificada na usina siderúrgica considerada

Tabela 26. Principais componentes do processo industrial e estimativa de falhas .........

Tabela 27. Relação dos sistemas a serem submetidos à avaliação das hipóteses de acidentes

Tabela 28. Estimativa de horas para identificação dos riscos da empresa

Tabela 29. Estimativa de horas para planejamento da ARA

Tabela 30. Estimativa de horas para elaboração da APR-A

Tabela 31. Estimativa de horas para elaboração da AE-A

Tabela 32. Estimativa de horas consumidas para elaboração das técnicas de análise de risco ambiental, por subsistema, em uma usina siderúrgica

Tabela 33. Estimativa do total de horas consumidas no processo de execução da ARA

\section{Lista de figuras}

Figura 1. Processos envolvidos na análise de risco ambiental

Figura 2. Poluentes e emissões gasosas gerados no processo siderúrgico

Figura 3. Representação gráfica dos diferentes tipos de análise de risco

Figura 4. Fluxo de produção do aço

Figura 5. Quantidade de acidentes envolvendo incêndio, explosão e vazamentos

Figura 6. Quantidade de acidentes segundo os locais de ocorrência, registrados no CADAC, de 1983 a 1997

Figura 7. Freqüência com que os diferentes meios foram atingidos, nos acidentes registrados no CADAC, entre 1983 e 1997

Figura 8. Ocorrência de acidentes envolvendo diferentes substâncias em usinas siderúrgicas, segundo o banco de dados SONATA

Figura 9. Ocorrência de acidentes nas diferentes unidades ou sistemas em usinas siderúrgicas, segundo o banco de dados SONATA

Figura 10. Quantidade de acidentes envolvendo incêndio, explosão e vazamentos, em indústrias siderúrgicas, segundo o banco de dados SONATA

Figura 11. Diagrama de bloco para realização de uma análise de risco

Figura 12. Fluxograma simplificado para realização de uma análise de risco

Figura 13. Procedimento geral para classificação de fábricas, processos e armazenamento 
Figura 14. Diagrama lógico para determinação do grau de risco de um processo industrial

Figura 15. Classificação dos riscos através da análise do processo industrial, armazenamento de substâncias perigosas e a sensibilidade ambiental da área circunvizinha

Figura 16. Primeira etapa na construção da AE para o exemplo apresentado

Figura 17. Representação da análise da primeira função do sistema de segurança .......

Figura 18. Representação do segundo sistema de segurança

Figura 19. Árvore de Eventos (AE) completa, para avaliação dos sistemas de segurança e ramificações possiveis

Figura 20. AE completa, incluindo as consequências da realização do evento base ......

Figura 21. Árvore de falhas para definição de caso

Figura 22. Liberação de substâncias inflamáveis

Figura 23. Liberação de líquidos inflamáveis ou tóxicos

Figura 24. Liberação de gases tóxicos

Figura 25. Classe de risco segundo CATBRAS modificada para: sinterização. 25 A: Classe de risco final para: sinterização

Figura 26. Classe de risco segundo CATBRAS modificada para: coqueria. 26 A: Classe de risco final para: coqueria

Figura 27. Classe de risco segundo CATBRAS modificada para: calcinação. 27 A: Classe de risco final para: calcinação

Figura 28. Classe de risco segundo CATBRAS modificada para: carboquimicos. $28 \mathrm{~A}$ : Classe de risco final para: carboquímicos

Figura 29. Classe de risco segundo CATBRAS modificada para: alto-forno. $29 \mathrm{~A}$ : Classe de risco final para: alto-forno

Figura 30. Classe de risco segundo CATBRAS modificada para: aciaria. $30 \mathrm{~A}$ : Classe de risco final para: aciaria

Figura 31. Classe de risco segundo CATBRAS modificada para: lingotamento contínuo. $31 \mathrm{~A}$ : Classe de risco final para: lingotamento contínuo

Figura 32. Classe de risco segundo CATBRAS modificada para: laminação de tiras a quente. $32 \mathrm{~A}$ : Classe de risco final para: laminação de tiras a quente (LTQ) .

Figura 33. Classe de risco segundo CATBRAS modificada para: laminação de tiras a frio. $33 \mathrm{~A}$ : Classe de risco final para: laminação de tiras a frio (LTF)

Figura 34. Classe de risco segundo CATBRAS modificada para: dessulfuração. 34 A: Classe de risco final para: dessulfuração

Figura 35. Classe de risco segundo CATBRAS modificada para: fábrica de oxigênio. $35 \mathrm{~A}$ : Classe de risco final para: fábrica de oxigênio 
Figura 36. Análise Preliminar de Risco Ambiental - APR-A (gasômetros - gases de coqueria)

Figura 37. Análise Preliminar de Risco Ambiental - APR-A (tratamento de amônia coluna de "stripping")

Figura 38. Análise Preliminar de Risco Ambiental - APR-A (tanque de alcatrão carregamento)

Figura 39. Análise Preliminar de Risco Ambiental - APR-A (tancagem - tanque de óleos leves)

Figura 40. Análise Preliminar de Risco Ambiental - APR-A (tancagem - tanque de licor de amônia)

Figura 41. Liberação de gases tóxicos - subsistema: coluna de "stripping" de amônia ...

Figura 42. Liberação de líquidos perigosos - subsistema: coluna de "stripping" de amônia

Figura 43. Liberação de substâncias inflamáveis - subsistema: gás de coqueria

Figura 44. Liberação de líquidos perigosos - subsistema: tanque de óleos leves (carregamento)

Figura 45. Quantidade de horas consumidas na realização das técnicas de ARA

Figura 46. Quantidade de horas consumidas no processo de realização da ARA 


\section{INTRODUCÃO}

\subsection{A INDÚSTRIA SIDERÚRGICA E OS RISCOS PARA O MEIO AMBIENTE}

O constante crescimento do volume e diversidade de produtos industriais cria uma probabilidade crescente e significativa de acidentes que envolvem a liberação de produtos tóxicos ou perigosos. Esses acidentes podem afetar a saúde humana causando mortandade ou morbidade entre os expostos, ou mesmo enfermidades retardadas. Podem afetar, também, as atividades empresariais e os sistemas que compõem o meio ambiente local.

Considerando o possível dano que a exposição a produtos potencialmente tóxicos pode causar à saúde humana e ao meio ambiente, torna-se necessário o aprofundamento dos conhecimentos que permitam a elaboração de mecanismos de prevenção de tais acidentes.

Segundo SILANO (1984), os acidentes que expõem tanto o homem como o meio ambiente podem surgir de várias maneiras, e não existem acidentes exatamente iguais. Esse autor classifica esses acidentes em quatro grupos:

- desastre/explosão em uma unidade ou em um armazém

- acidente durante o transporte de produtos

- uso indevido de produtos, resultando na contaminação de alimentos ou do meio ambiente

- manejo inadequado de resíduos

Nessa sua consideração, o autor não leva em conta, evidentemente, o risco de exposição contínua, que afeta o meio ambiente e, mais especificamente, a saúde humana.

Esta posição vem sendo discutida, no sentido de comparar os conceitos de acidentes pontuais com os problemas advindos da exposição contínua, provocada pela emissão constante de certos poluentes.

A maioria dos trabalhos científicos divulgados trata de acidentes com liberação de produtos tóxicos ou perigosos e das formas de sua predição e prevenção (LEES, 1980; CONWAY, 1982; SILANO, 1984; LE SAUX, 1986; STALLEN \& TOMAS, 1988; ESCHENROEDER \& FAEDER, 1988; MASSAD, 1990; CALABRESE \& KENYON, 1991; OIT, 1992; SHOWALTER \& MYERS, 1994; HERY et al., 1996; PORTO \& FREITAS, 1996). Esses trabalhos vêm procurando sempre relacionar esse tipo de acidente às conseqüências sobre a saúde humana. Outros artigos relacionam a exposição continuada a alguns produtos e os danos ao ecossistema ou uma espécie em particular (SILVEIRA et al., 1982; NAVAS-PEREIRA et al., 1985; BERTOLETTI et al., 1989; ZAGATTO \& GHERARDI-GOLDSTEIN, 1991; LANDRUM et al., 1992; GREIG-SMITH, 1992; KENDALL \& AKERMAN, 1992; NORTON et al., 1992; TRAVIS \& MORRIS, 1992; BARNTHOUSE, 1992, 1994; MÖLLER et al., 1993; FOSTER \& HIRATA, 1993; ROSE, 1994; SUTER II et al., 1995; CORSEUIL \& MARINS, 1997).

Em conseqüência da complexidade dos problemas ambientais, que apresentam múltiplas causas e diversos efeitos ecológicos, os estudos que envolvem o meio ambiente procuram adequar e particularizar os eventos, as situações controláveis, ou então se voltam para diagnósticos obtidos através de dados históricos.

No entanto, tem-se notado um crescente interesse no uso de dados de processo aliados a dados ecológicos como base para decisões que envolvem a questão ambiental. Nesse sentido, a USEPA - United States Environmental Protection Agency apresentou, no "Risk Assessment Forum", ocorrido em 1992, uma proposta que descreve os elementos básicos de uma avaliaçăo de risco ecológico. Nesse contexto, a USEPA (1992) conceitua o risco ecológico como sendo a "probabilidade da ocorrencia de efeitos ecológicos adversos como resultado de exposiçăo a estressores relacionados as atividades antropicas, tais como drenagem de áreas inundáveis ou emissăo de poluentes". 
Os estressores que podem ser arrolados no conceito são descritos como um produto químico, físico ou biológico que induza um efeito adverso a um componente ecológico (individuo, população, comunidade ou ecossistema).

NORTON et al. (1992), analisando a referida proposta, resumem as recomendações do comitê diretivo da entidade em três itens:

- a EPA deve dirigir seus esforços objetivando a proteção ambiental baseada na oportunidade de ocorrência de acidentes maiores;

- a EPA deve dar a mesma importância ao risco ecológico que a dada à redução do risco humano;

- a EPA deve desenvolver dados e metodologia analítica para possibilitar a avaliação, comparação e redução dos diferentes riscos ambientais.

A idéia da presença do estressor, tratando-se este de um produto químico ou de fatores físicos e biológicos, amplia o conceito de CONWAY (1982) para a análise de risco ambiental, que envolve o conhecimento e análise básica da entrada da substáncia química no ambiente, seu destino e os efeitos dessa substância química sobre os ambientes aquático, atmosférico e terrestre, o uso de modelos matemáticos e ecológicos e considerações sobre a saúde humana.

O conceito adotado pela EPA considera o elemento causador como qualquer agente químico, físico ou biológico e também a probabilidade do dano ecológico; já o proposto por CONWAY (1982) considera o mecanismo de entrada e transformaçöes do elemento causador. Os dois conceitos focalizam o meio ambiente, porém a análise de risco ambiental de CONWAY considera, além do efeito ecológico, os mecanismos de transformaçōes e o destino do estressor.

Uma mescla dos dois conceitos levará a uma consideração mais abrangente envolvendo estressores químicos, físicos e biológicos e os efeitos adversos sobre o meio ambiente e a saúde humana, além dos componentes matemáticos usados para estudos e predições das emissões ao meio ambiente e reações químicas secundárias.

A aparente mistura de termos usados nos conceitos citados - avaliaçăo de risco ecológico (Ecological Risk Assessment) e análise de risco ambiental (Environmental Risk Analysis) mostra definiçōes semânticas que, como pode ser observado na explicitação de conceitos, discordam quanto ao componente sob efeito do estressor. Nesse caso, a análise de risco ambiental atende melhor ao que se pretende neste trabalho, ampliada, entretanto, com a introdução do conceito de outras formas de estressores (biológico e físico).

Dessa forma, fica definido que, para o presente trabalho, considerou-se a Analise de Risco Ambiental, que envolve:

a) identificar as operações ou atividades com produtos perigosos que possam gerar acidentes,

b) conhecer os principais estressores emitidos em caso de um acidente, e

c) avaliar os efeitos adversos a que estão sujeitos o meio ambiente e a saúde humana na área de influência de um processo produtivo identificado como potencial gerador de acidentes.

Partindo-se dessa premissa, deve-se considerar, portanto, a possibilidade da ocorrência de um acidente com a presença de substância química ou agentes físicos e biológicos, que possam causar danos ambientais e/ou à saúde humana, além das perdas patrimoniais. A hipótese de trabalho envolve, portanto, a possibilidade de um acidente com a presença de um agente estressor que venha a causar danos ambientais.

$\mathrm{Na}$ realidade, durante os levantamentos feitos para a realização deste trabalho, outras situações foram evidenciadas, que de alguma forma redundam em um risco ao meio ambiente, identificadas, por exemplo, como:

- emissão constante de poluentes líquidos e gasosos - controlados ou não;

- uso indevido do solo para armazenamento ou disposição de resíduos sólidos (doméstico, hospitalar ou industrial);

- circulação de veículos que provocam emissões significativas de pó e gases de combustão. 
Mesmo os riscos em si podem ser classificados de acordo com o que será atingido pelo efeito do acidente. Além do ambiente, pode ser atingido ainda o patrimônio da empresa - podendo ser considerado desde uma simples parada para correção até a perda total da produção, do ativo fixo ou cessação das atividades de partes ou de toda a empresa. $O$ acidente pode atingir ainda o ser humano. Nesse caso, os efeitos poderiam ser danos físicos aos empregados ou vizinhos da unidade, danos morais ou até mesmo a perda do emprego ou de receita para os órgãos públicos.

Os riscos podem envolver tipos distintos de acidentes com produtos perigosos, tais como explosão, incêndio e vazamento de produtos tóxicos ou não. Cada tipo de acidente traz uma conotação diferente no que se refere aos efeitos sobre quem ou o quê é atingido. Além disso, há uma graduação dos efeitos sentidos no meio ambiente ou outro sistema atingido.

Assim, uma explosão, dependendo, evidentemente, de sua magnitude, tem efeito acentuado sobre o patrimônio da empresa, tanto o financeiro como o instrumental e principalmente o humano; porém, o dano ambiental poderá ser inexpressivo.

O incêndio tem as mesmas considerações anteriores, porém deverá ser melhor estudado quando, durante o evento, ocorrer emissão significativa de fumaça preta, resíduo de uma combustão incompleta, ou de gases tóxicos. Outro problema a ser considerado durante um incêndio é o resíduo gerado pelo uso de produtos ou água na extinção do fogo. Nesse caso, poderá haver formação de efluentes líquidos ou semilíquidos, tóxicos ou não, devidos principalmente aos produtos estocados na área ou ao próprio elemento usado na extinção. De qualquer forma, esse é um tipo de acidente que acaba sendo englobado no terceiro e mais sério problema de acidente com efeitos ambientais, que é o vazamento.

No caso do vazamento, o patrimônio e o homem são menos atingidos, devendo ser considerada, no entanto, a extensão do evento. Já o meio ambiente poderá ser muito prejudicado, dependendo das medidas de controle existentes e do tempo decorrido entre o início do evento e as medidas adotadas para controle efetivo da emissão.

Como exposto, a cada tipo de acidente pode corresponder uma série de eventos, que, se analisados separadamente, levariam a um estudo muito complexo, envolvendo áreas tão distintas como a da medicina, a da economia e a da engenharia. O fluxograma apresentado na figura 1 traduz a complexidade do estudo quando são abarcados todos os cenários possíveis. Nele, são apresentadas as fases em que os conceitos de risco e de acidentes estão envolvidos:

- Risco do processo: refere-se à identificação dos riscos inerentes ao processo de produção. São aqueles riscos definidos anteriormente como passíveis de causarem um acidente com produtos perigosos. Refere-se também às emissões de poluentes ou substâncias perigosas.

- Técnicas de análise de risco: refere-se à identificação das técnicas de análise de risco mais apropriadas para avaliação da probabilidade e freqüência de ocorrência de um determinado acidente.

- Estimativa e simulaçăo de consequências: refere-se à identificação das técnicas e modelos matemáticos mais apropriados para simular e avaliar as conseqüências de um determinado acidente. Esses modelos e técnicas devem levar em consideração fatores importantes como os determinados no estudo da área geográfica do empreendimento: região, área de influência da unidade, dispersão dos produtos tóxicos, volume dos produtos tóxicos emanados ou liberados por acidente, topografia, sentido de corrente (ar e água), entre outros.

- Análise de risco ambiental: refere-se à identificação e análise dos riscos decorrentes de operações ou atividades com produtos perigosos, ou de emissões contínuas, considerando os dados obtidos nas etapas anteriores e as transformações desses produtos nos meios (ar, água e solo), bem como os seus efeitos sobre os ecossistemas e a saúde humana.

As técnicas para estimativa de consequências estão bem definidas para a análise do comportamento de emissões nos diversos ambientes. Modelos de dispersão de poluentes atmosféricos estão disponiveis no mercado, em "softwares" que agilizam a simulação de situações que envolvem a emissão de gases para a atmosfera. $O$ mesmo vale para dispersão de efluentes e substâncias tóxicas nos corpos hidricos, tanto de águas interiores como marinhas. 
Figura 1. Processos envolvidos na análise de risco ambiental

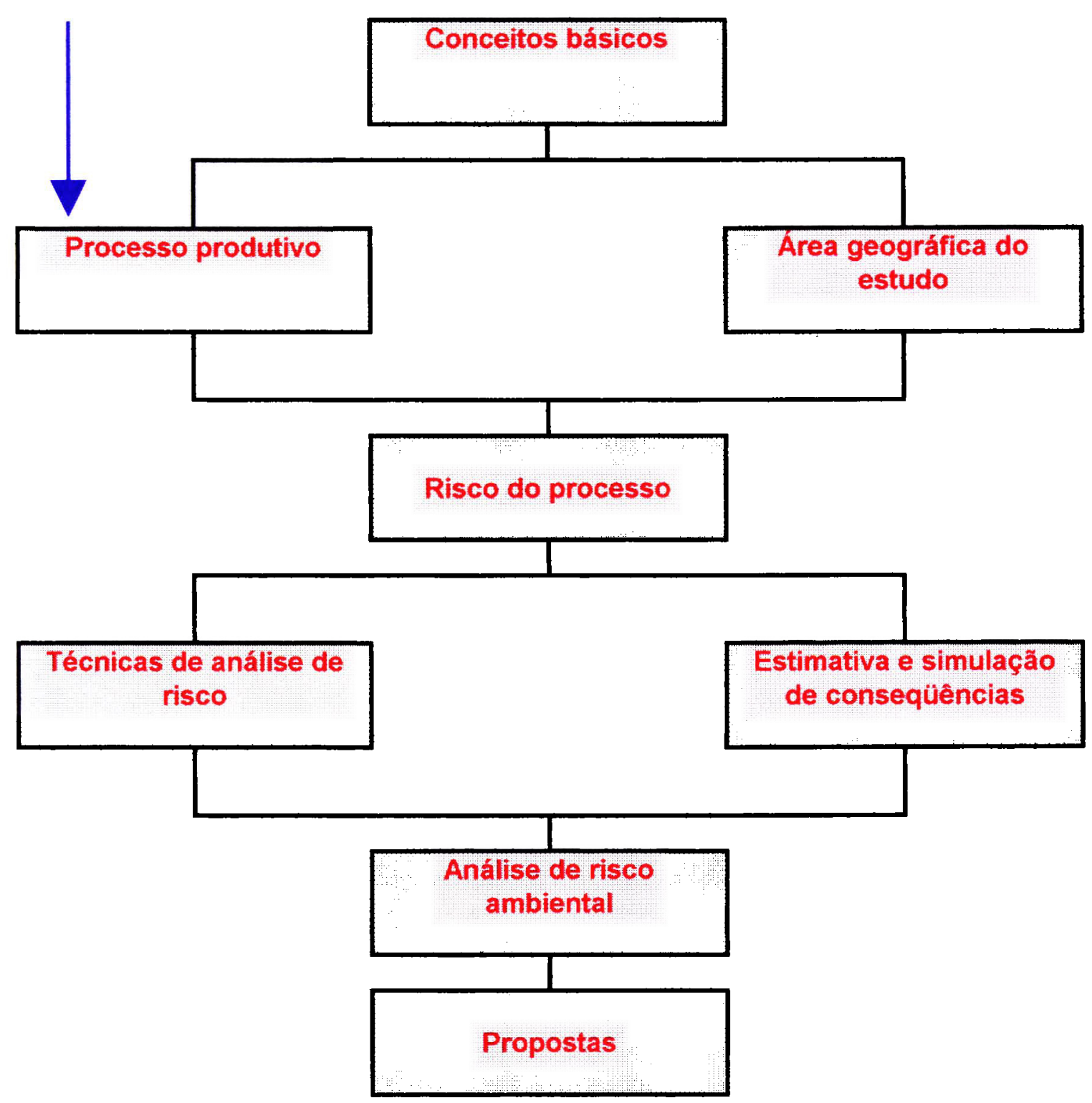

O comportamento de produtos tóxicos no solo também pode ser avaliado por técnicas e modelos que permitem simular e conhecer os efeitos e caminhos preferenciais desses produtos nesse meio, até atingirem os aqüíferos da área afetada.

As técnicas para analisar os riscos do processo produtivo também existem, porém não estão ainda definidas quanto à sua aplicação em determinados processos. Na realidade, essas técnicas foram elaboradas para serem utilizadas nas indústrias químicas. Outros processos podem se beneficiar dessas técnicas, porém devem ser feitas consideraçöes quanto aos seus limites e interpretaçäo dos resultados.

Entretanto, a análise de risco ambiental, ao contrário dos demais aspectos anteriores, não tem técnicas específicas definidas para se conhecer, avaliar e mesmo propor o gerenciamento do risco ao meio ambiente. As técnicas disponiveis são as mesmas referentes à análise de risco do processo, que não levam em conta as variáveis ambientais, tais como a interaçăo do meio com o produto tóxico, suas transformaçōes fisico-quimicas, e efeito sobre os ecossistemas, incluindo aí 
a saúde humana. A falta de técnicas que avaliem também a probabilidade de danos ao meio ambiente tem dificultado o entendimento do problema e a realização de estudos que identifiquem e proponham controles para os eventos indesejáveis identificados.

Como exposto anteriormente, a análise de risco ambiental - ARA deve ser aplicada a processos ou atividades industriais que contenham a probabilidade de produzir acidentes envolvendo explosão, incêndio ou liberação (vazamento/derrame) de produtos perigosos que possam afetar adversamente a saúde humana, o patrimônio da empresa e o meio ambiente. Para auxiliar o empreendedor ou órgão de controle ambiental sobre a necessidade de execução ou não da ARA no processo siderúrgico, deve-se levar em conta os seguintes fatores:

- processos que apresentam situações propícias para acidentes;

- número de empregados (elevado);

- idade das instalações/novos projetos;

- manutenção dos equipamentos;

- dimensão dos processos;

- volume de produção;

- relação matéria prima $x$ resíduos gerados;

- armazenamento de substâncias perigosas;

- local onde essas indústrias se instalaram (ou pretendem se instalar);

- tendências de dispersão dos poluentes (estressores);

- persistência dos estressores no meio ambiente;

- tendência à bioacumulação e condições biogeofísicas para tal;

- toxicidade dos estressores;

- proximidade de núcleos urbanos;

- eficiência da fiscalização legal;

- consciência empresarial;

- exigências legais.

Nesse caso, a indústria siderúngica nacional se enquadra perfeitamente na exigência de elaboração da ARA, pois cada um dos itens mencionados refere-se a um potencial real de acidente e efeitos negativos e que expõe os trabalhadores e o meio ambiente a situação de risco. Deve ser levado em conta, ainda, o fato de essas empresas terem sido protegidas até recentemente pelo Estado, o que resultou no descuido quanto à questão ambiental e quanto à possibilidade de danos advindos de processos ultrapassados e sem o devido controle.

O fluxograma apresentado na figura 2 evidencia um processo siderúrgico integrado a coque (existem outros processos onde a obtenção do produto pode ser segmentada, ou que utilizam lenha). Nele, podem ser identificadas as principais fontes de geração de gases ou outros poluentes importantes e os pontos potenciais de riscos de acidentes maiores, tais como explosões, vazamentos e incêndios. O fluxograma não identifica os locais dentro dos processos onde são armazenados combustiveis líquidos ou perigosos. Somente mostra, evidentemente, os processos que, por sua natureza, utilizam produtos perigosos ou estão sujeitos a acidentes com conseqüências ambientais.

O fato de se optar pela aplicação das propostas técnicas de análise de risco ambiental a um processo integrado justifica-se pela sua complexidade, e por conter todos os segmentos da indústria siderúrgica.

Praticamente, todo o processo apresenta de alguma forma um agravante ambiental, sugerindo portanto ser fundamental para as empresas, para os órgãos de controle ambiental e para os legisladores, terem em mãos uma pesquisa de cunho acadêmico e científico, para poderem traçar diretrizes e políticas de prevenção, bem como para a fiscalização de acidentes ou emissões que possam conter algum risco de acidente ou impacto ambiental.

Define-se, deste modo, o tema que é o assunto da tese, e a problemática da investigação envolvida na delimitação requerida. A elaboração de técnica apropriada para a análise de risco ambiental, como proposto, contempla todos os conceitos e critérios obtidos, prevendo sua 
Figura 2. Poluentes e emissరes gasoses gerados no processo siderúrgico (seg. YOSHIDA, 1992, modificado)

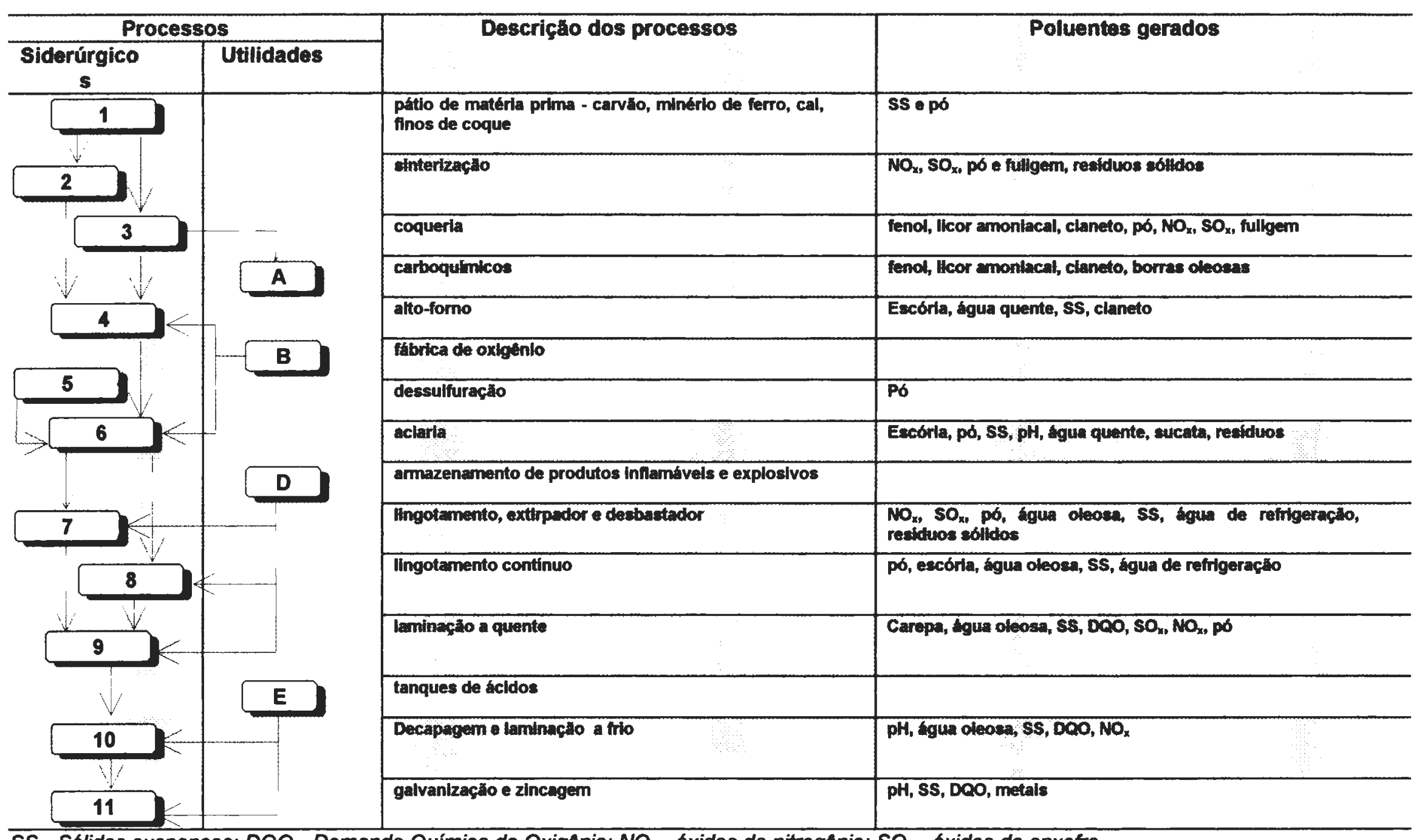

SS - Sólidos suspensos; DQO - Demanda Química de Oxigenio; $\mathrm{NO}_{x}$ - oxidos de nitrogénio; $\mathrm{SO}_{\mathrm{x}}$ - 6xidos de enxofre 
aplicação nos diversos estágios do processo siderúrgico, em condições de facilitar sua execução, monitoramento e auditoria, estimando os custos financeiros necessários, além de propor adequações na legislação ambiental competente.

\subsection{ESTUDO DE IMPACTO AMBIENTAL X ANÁLISE DE RISCO AMBIENTAL}

Com relação aos riscos de acidentes maiores, definidos e regulamentados pela Diretiva de Seveso, 82/501/CEE de 27 de junho de 1985, a Comunidade Européia, como citado por MILARÉ \& BENJAMIN (1993), editou a Diretiva 85/337 que cuida do Estudo de Impacto Ambiental (EIA). Essa Diretiva ressalta que "a melhor política ambiental consiste na prevenção, na fonte, da poluição ou perturbação, em vez de, posteriormente, tentar reagir aos seus efeitosn.

A Resolução $n^{\circ} 01$ de 23 de fevereiro de 1986 do Conselho Nacional do Meio Ambiente (CONAMA, 1986a) considera como impacto ambiental "qualquer alteração das propriedades físicas, químicas e biológicas do meio ambiente, causada por qualquer forma de matéria ou energia resultante das atividades humanas que, direta ou indiretamente, afetam: a saúde, a segurança e o bem-estar da população; as atividades sociais e econômicas; a biota; as condições estéticas e sanitárias do meio ambiente; a qualidade dos recursos ambientais."

Para MILARÉ \& BENJAMIN (1993), o Estudo de Impacto Ambiental (EIA) não é um instrumento casuístico, mas sistematiza no plano teórico alguns, entre tantos outros objetivos do EIA :

- prevenção do dano ambiental;

- transparência administrativa quanto aos efeitos ambientais de um determinado projeto;

- consulta aos interessados;

- decisões administrativas informadas e motivadas.

RODRIGUES (1990), em sua dissertação de mestrado, relaciona as principais deficiências das metodologias de avaliação de impactos ambientais, conforme expresso na Resolução CONAMA n. 01 (CONAMA, 1986a). Entre elas, destaca-se a consideração de que "tais métodos não analisam os fatores de risco ou incertezas, que são muito importantes no processo de planificação regional e setorial". Em outro ponto de suas observações, comenta - "o sistema instituído não avalia as questōes de risco ambiental. Esta avaliação implica em uma nova estruturação técnica e operacional do sistema, bem como na definição de uma estratégia no estabelecimento de ações prioritárias e evolução gradativa da abrangência dos estudos".

Segundo RODRIGUES (1990), "a análise de risco ambiental decorre não só das características intrínsecas do empreendimento, mas também das interações que este mantém com seu entorno, dentro de sua área de influência. Depreende-se que o nível de risco avaliado e aceito quando do processo de licenciamento para implantação de uma atividade com potencial de causar algum impacto, estará sujeito a alteração em função da dinâmica de desenvolvimento das demais atividades no entorno".

O EIA é um documento a ser apresentado, na forma da lei, para instalação de obra ou atividade potencialmente causadora de significativa degradação do meio ambiente (MILARÉ \& BENJAMIN, 1993). Carece, portanto, de uma identificação anterior quanto a esse potencial e não abrange a totalidade das atividades industriais.

Já a análise de risco ambiental é um documento a ser elaborado a qualquer momento, podendo portanto fazer parte do EIA, que visa identificar, avaliar a probabilidade de ocorrência, e prever as conseqüências de um acidente provocado por uma atividade gerada pelo homem.

Deduz-se, portanto, que se trata de conceitos e técnicas diversas, porém com um objetivo comum, que é a proteção do meio ambiente, incluindo todos os seus componentes. 


\subsection{A ANÁLISE DE RISCO AMBIENTAL E A LEGISLAÇÃO}

COVELLO et al. (1988) comparam o entendimento da necessidade e interpretação da análise de risco ambiental no Japão e nos Estados Unidos. Ambos os paises concordam com uma tendência que evidencia um aumento:

- no desenvolvimento e mudanças científicas e tecnológicas, resultando em aumento na escala física e na complexidade dos riscos tecnológicos;

- na sensibilidade dos métodos analiticos, evidenciando cada vez mais as condições adversas para a saúde e meio ambiente;

- do conhecimento científico sobre os efeitos adversos na saúde e meio ambiente;

- no custo da tecnologia de controle relacionada com os riscos ambientais;

- nas conseqüências adversas sobre a economia e a sociedade.

Observaram ainda os mesmos autores que, em ambos os países, grupos de cidadãos têm se tornado substancialmente mais ativos quanto aos riscos ambientais. Essas observações têm conduzido tanto os governos desses países quanto os administradores e empresários a considerarem o assunto risco ambiental como relevante em suas decisões.

RITTER (1988) advogou o uso do gerenciamento do risco como um critério a ser adotado pelos tomadores de decisão para desenvolver políticas de saúde e meio ambiente. Segundo o mesmo autor, a análise de risco poderá permitir avaliações quantitativas e comparativas dos riscos à saúde e ao meio ambiente, bem como estabelecer prioridades que permitam a tomada de decisão sobre os riscos que devam ser tratados prioritariamente.

MANSOT (1986) fez uma avaliação da legislação francesa referente à prevenção do risco na indústria química, e ressaltou que, à exceção de uma lei de 1977, que trata do controle de produtos químicos, não havia sido desenvolvido na França, até então, um quadro jurídico específico para o controle da indústria química. Considerou que, em outros países, especialmente aqueles em desenvolvimento, a situação não deve ser diferente. Comentou ainda o autor que a responsabilidade do Estado francês na administração do risco contraria a disposição de outros países, como Japão, Estados Unidos, Alemanha, Suíça, onde as responsabilidades são divididas entre os diferentes niveis administrativos (central, regional, municipal).

GREIG-SMITH (1992) relatou o quadro da legislação sobre o risco de acidentes com produtos químicos no Reino Unido. $O$ artigo se refere à avaliaçăo do risco ecológico em consequeência do uso de pesticidas. Relata o autor que a autorização de uso é centralizada no Ministério da Saúde, porém pode ser necessário o aval de seis outras entidades ou administrações regionais. Com a entrada na Comunidade Econômica Européia, a tendência è a uniformização do licenciamento dos produtos, a partir de uma análise de risco ambiental do produto, com validade para todos os paises membros da CEE.

Na América Latina, os estudos para adoção de normas de segurança quanto ao risco restringemse a alguns poucos produtos e processos. No Brasil, a indústria química, por seus processos que envolvem altos riscos (pressão, temperatura, toxicidade), tem se preocupado mais com a questão dos acidentes e emissões contínuas (RUBIO, 1992). No entanto, a legislação ambiental não tratava especificamente do assunto. Em dezembro de 1997, surgiu o primeiro regulamento (Resolução CONAMA n 237, de 19 de dezembro de 1997 - CONAMA, 1997), que prevê o uso da análise preliminar de risco como um dos estudos ambientais que pode ser exigido no processo de licenciamento ambiental, carecendo, no entanto, de melhores definições quanto ao seu uso e avaliação.

A indústria nacional de um modo geral, e a siderúrgica em particular, apresenta os mesmos problemas evidenciados quanto às exigências legais. Não existe uma legislação pertinente que exija ou regulamente a análise de risco do processo, armazenamento, transporte e comercialização dos produtos gerados ou adquiridos. Em alguns casos existe uma análise de risco do processo, que visa unicamente identificar falhas, no sentido da previsão de perdas e paradas de produção. Esta análise normalmente é exigida para fins de contrato de seguros patrimoniais (OLIVEIRA, 1986). 
No trabalho que relata as conclusões do grupo reunido pelo Banco Mundial para discussão do assunto, RASMUSSEN \& BATSTONE (1989) consideram a análise de risco como um instrumento fundamental para o gerenciamento de risco, que deve ser desenvolvido por especialistas e administrado pelos responsáveis pela empresa. O processo de gerenciamento envolve a identificação do risco, sua quantificação e a decisão quanto à sua aceitabilidade. Concluem os autores, portanto, que a análise de risco preditiva é uma ferramenta importante para o controle da segurança em sistemas industriais ou de produtos, porém sem uma exigência legal para sua realização.

\subsection{A ANÁLISE DE RISCO AMBIENTAL E O CUSTO DE SUA REALIZAÇÃO}

Em recente publicação, DITZ et al. (1995) apresentam um estudo quanto à contabilidade ambiental dentro das empresas. Seu trabalho consiste em um levantamento feito em várias empresas multinacionais de grande porte e que têm registrado os custos da proteção ambiental. Tais custos envolvem, na maioria das empresas pesquisadas, os seguintes tópicos:

- tratamento de efluentes

- disposição de resíduos (aterros, incineração, "landfill", etc.)

- recuperação de produtos

- especificação dos produtos

- gerenciamento ambiental

- taxas e multas

- manutenção

- depreciação

- perdas

- mão de obra

- energia (utilidades)

Ainda segundo os mesmos autores, esses custos incidem diretamente sobre o preço final do produto e normalmente são contabilizados, embora a grande maioria das empresas consultadas não tenham esse dimensionamento, e nem a preocupação, de avaliar a participação da variável ambiental nos seus custos totais. Entre as empresas pesquisadas, observou-se uma variação entre 2,4 e 22 por cento do custo operacional do produto, com o controle dos aspectos ambientais.

A técnica aplicada pelas empresas que realizam esse monitoramento é lançar os custos com o tratamento de suas emissões como "custos variáveis", à exceção dos equipamentos permanentes e da depreciação, que são lançados como "custos fixos".

A análise dessa publicação mostra que não há um item específico para análise de risco ambiental, ficando o dimensionamento dos custos ambientais restritos ao controle da poluição. Mesmo em empresas químicas, que normalmente têm a preocupação com a possibilidade da ocorrência de acidente (produção, transporte ou mesmo utilização pelo consumidor final), esse custo não é apresentado ou contabilizado. Os autores não comentam, no entanto, se essa contabilidade pode estar sendo lançada como um custo estimado para redução do prêmio do seguro.

O não conhecimento dos custos de realização de uma ARA tem sido um entrave para o empreendedor. Por não ter meios gerenciais sobre os gastos envolvidos no controle dos aspectos ambientais e de segurança, é criada uma expectativa errada entre os administradores de que o dispêndio com a prevençāo do acidente é um custo que pode ser postergado para uma "melhor oportunidaden. Alie-se a este fato a ação de empresas de consultoria que não informam ao empreendedor qual deveria ser um custo justo para solução que envolve os aspectos citados, e quais os ganhos diretos e indiretos contidos na prevenção de acidentes e de perdas.

\subsection{OBJETIVOS}

O levantamento realizado para efetivação deste trabalho evidenciou que pouco se conhece a respeito dos riscos ambientais advindos de um processo siderúrgico. No entanto, o processo é altamente poluente e apresenta vários componentes que geram a probabilidade de um acidente, 
classificado desde de pequenas proporções até de proporções catastróficas. Considerando os vários estágios, ou indústrias, que compổem o processo siderúrgico, deve-se ter em mente que a operação dos sistemas, o armazenamento de substâncias perigosas, as dimensões de tubulações de gases e tanques, o volume de produtos envolvidos na produção de coque, gusa, aço, trazem um sério risco de acidentes para a unidade.

A falta de uma legislação específica para a operacionalidade de uma análise dos riscos inerentes aos processos, com conseqüência ambiental, coloca o administrador numa situação cômoda, em que não se observa a preocupação com o dano ambiental ou à saúde humana.

Da mesma forma, a falta de normas e procedimentos específicos dificulta a execução da análise de risco ambiental. Embora existam várias técnicas disponíveis para analisar e avaliar o risco de um processo qualquer, não há a padronização nem o direcionamento dessas técnicas para a análise que considere a variável ambiental. As técnicas mencionadas preconizam o risco, porém são voltadas quase que exclusivamente para identificação e prevenção de acidentes que possam causar danos à saúde do trabalhador, perdas por parada de produção, afastamento dos empregados, e perdas patrimoniais.

Isso tudo leva a uma ação precária da fiscalização, que luta pela existência de uma legislação pertinente e formas normatizadas de execução das análises de risco.

Aliado a esses fatores, encontra-se o total desconhecimento dos custos relativos à análise e prevenção dos riscos ambientais, e sua participação nos custos dos produtos das empresas.

Finalmente, inexiste uma cultura empresarial e oficial que privilegie a análise de risco, processual e ambiental, como instrumento de gestão industrial, através do gerenciamento de riscos, dentro de um sistema maior de gerenciamento ambiental.

A partir dessas premissas, foram estabelecidas as hipóteses que serviram para se definir os objetivos específicos da tese, os quais passam a ser delineados a seguir:

\section{Hipóteses}

- Metodologia deficiente para a execução de uma análise de risco ambiental, para o processo siderúrgico

\section{Objetivos específicos}

- Elaborar uma proposta de metodologia adequada para a execução de uma análise de risco ambiental, para o processo siderúrgico.

- A legislação relativa à análise de -Propor alteração na legislação ambiental, de forma a risco ambiental é omissa. abranger a análise de risco ambiental.

- Não se conhece os custos envolvidos na análise e no gerenciamento dos riscos ambientais.
- Estimar os custos relativos incidentes sobre uma empresa siderúrgica, decorrentes da análise e gerenciamento de riscos ambientais.

O atingimento desses objetivos deverá permitir apresentar técnicas alternativas para a análise de risco ambiental de processos industriais - e, em especial, do siderúrgico -, além de contribuir para o aprimoramento da legislação ambiental e o gerenciamento de riscos, através de uma estimativa de custo da realização das análises de risco ambiental. 


\section{METODOLOGIA E ESTRUTURA DA TESE}

Os objetivos específicos da presente tese foram alcançados através de pesquisa envolvendo as seguintes atividades:

- elaboração de uma proposta de metodologia adequada para a execução de uma análise de risco ambiental (ARA), para o processo siderúrgico.

- elaboração de uma proposta de alteração na legislação ambiental, de forma a abranger a análise de risco ambiental.

- quantificação dos custos relativos incidentes sobre as empresas siderúrgicas, decorrentes da análise e gerenciamento de risco ambiental.

\subsection{ELABORAÇÃo DE UMA PROPOSTA DE METODOLOGIA ADEQUADA PARA A EXECUÇÃo DE UMA ANÁlISE DE RISCO AMBIENTAL, PARA O PROCESSO SIDERÚRGICO.}

Para atender a esse objetivo, foram desenvolvidos os seguintes estágios:

1. Definição dos conceitos básicos necessários para a compreensão do tema em desenvolvimento. Isto se deu através do inventário de todos os métodos, técnicas, procedimentos, normas, manuais, etc., disponiveis para o embasamento teórico e prático, referentes às formas existentes de análise de risco ambiental. Esse trabalho foi realizado através de consultas bibliográficas e pessoais com especialistas do ramo, tanto nacionais quanto internacionais.

2. Levantamento, através de bibliografia especifica da área siderúrgica e realização de visitas técnicas, de todo o processo de obtenção do aço, desde o processo de mineração, até a entrega aos clientes.

3. A identificação dos acidentes do processo siderúrgico, conforme explicitado anteriormente, foi obtida através de dados históricos de acidentes em unidades siderúrgicas ou processos semelhantes aos existentes em cada um dos estágios de obtenção do aço. $O$ trabalho foi realizado através de consultas e visitas técnicas a algumas empresas do ramo e refere-se a:

- Estudos por unidade - seleção, dentro do processo em estudo, da unidade de produção que realmente apresente alguma forma de risco de acidente com conseqüente dano ambiental.

- Produtos envolvidos - foram relacionados todos os produtos, subprodutos e rejeitos que possam estar envolvidos na produção, estocagem, transporte e destinação final.

- Classificação e caracterização dos produtos - obteve-se a classificação, características físico-químicas e toxicológicas da substância ou produto que possa significar um risco ao meio ambiente.

- Identificação de fonte de dados de acidentes - identificaram-se as fontes de informação sobre dados relativos a acidentes ambientais em processos semelhantes ao estudado.

- Histórico de acidentes - obtenção de um histórico de acidentes com conseqüências ambientais, em processos semelhantes ao que se propõe neste trabalho, em nível nacional e internacional.

- Principais riscos - determinaram-se os principais riscos envolvidos numa unidade, considerando o histórico dos acidentes ou utilizando informações contidas em publicações técnicas especializadas.

- Identificação dos controles existentes - foi efetuado o levantamento de informações ou dados reais, evidenciando quais as formas técnicas e propostas de engenharia mais adequadas para prevenir ou mitigar os riscos de acidentes com conseqüências ambientais.

4. Identificação das técnicas de análise de risco que melhor permitem uma significativa análise dos riscos de acidentes em processos semelhantes ao que é objeto do presente estudo. Além da apresentação, com descrição sucinta de sua operacionalidade, foi considerada ainda uma graduação de importância e envolvimento na análise de risco com conseqüência ambiental. 
Entre as técnicas possiveis de análise de risco, foram selecionadas e analisadas com mais critério aquelas que mais se adaptam aos riscos ambientais presentes em um processo. A proposta de aplicação de uma ou mais técnicas foi embasada em situações já vivenciadas, relatadas em publicações técnicas e na possibilidade de aplicação com conseqüente ganho na análise do risco e na proposta de correção/mitigação.

5. Dentre as técnicas aplicadas na execução da análise de risco e na estimativa e simulação de conseqüências para avaliação do comportamento do poluente no ambiente, selecionou-se aquelas que permitam uma melhor avaliação do grau de dispersão, persistência ou mobilidade, e sejam aplicáveis ao processo em estudo, considerando o risco de envolvimento de ecossistemas naturais.

6. A análise e avaliação das informações levantadas nos estágios anteriores permitiram a proposição de três técnicas de análise de risco ambiental. A ARA, como proposta, inclui todos os conceitos e critérios obtidos, prevendo sua aplicação nos mais diversos estágios do processo siderúrgico, em condições ambientais regionais e na facilidade de execução, monitoramento e auditoria.

7. Selecionadas as técnicas de análise de risco, foi feito o seu aprimoramento para levar em conta todos os aspectos relativos ao meio ambiente, propondo as modificações necessárias para atender à demanda de identificar os produtos perigosos, tipos de acidentes, meios afetados, graduação do risco em relação ao dano observado e medidas preventivas e/ou corretivas.

Concluidas as etapas anteriores referentes à identificação dos prováveis acidentes inerentes ao processo industrial, identificação e seleção das técnicas de análise de risco que melhor se adaptam ao objetivo proposto e efetuadas as modificações necessárias nas técnicas selecionadas, foi realizada uma aplicação prática das técnicas aprimoradas, em um sistema produtivo de uma usina siderúrgica integrada a coque, o que permitiu avaliar a classe de risco das diversas unidades de produção e avaliar as consequências da realização dos riscos maiores identificados.

\subsection{PROPOSTA DE ALTERAÇÃO NA LEGISLAÇÃO AMBIENTAL, DE FORMA A ABRANGER A ANÁLISE DE RISCO AMBIENTAL}

Essa atividade foi desenvolvida através do estudo das várias legislações internacionais, federal e estaduais existentes, que foram solicitadas a todos os Estados da federação, através de correspondência encaminhada aos órgãos estaduais de meio ambiente, secretarias de Estado que tratam dos assuntos de meio ambiente, e Procuradorias estaduais ou federais, ligadas ao meio ambiente. A partir desse estudo e em função da proposta de uma metodologia para análise de risco ambiental, desenvolvida no presente trabalho, é apresentada uma sugestão, para que se incorpore à legislação ambiental, ou onde couber:

- de uma exigência legal de execução da análise;

- da(s) técnica(s) mais recomendável(is) para a execução da análise;

- das formas de monitoramento e auditoria dos resultados da análise;

- da fiscalização do cumprimento de execução e monitoramento dos resultados obtidos.

\subsection{QUANTIFICAÇÃO DOS CUSTOS RELATIVOS INCIDENTES SOBRE AS EMPRESAS SIDERÚRGICAS, DECORRENTES DA ANÁLISE E GERENCIAMENTO DE RISCO AMBIENTAL}

O estudo relativo à quantificação dos custos envolvidos na realização da análise de risco ambiental foi efetuado prevendo a sua aplicação em projetos, bem como desenvolvimento de modelos e de mão de obra especializada. Os levantamentos necessários para caracterizar e executar essa atividade foram efetuados com dados de mercado e consulta a especialistas que atuam nessa área. A partir dessas informações, é apresentada uma avaliação dos custos financeiros e da necessidade de capacitação dos recursos humanos para a execução das técnicas da ARA em um empreendimento. 
Além dos itens propostos originalmente no plano de trabalho, foram também abordados aspectos referentes à comunicaçăo de riscos e ao gerenciamento dos riscos, cuja discussão é relevante para o completo entendimento, aplicação e obtenção de resultados efetivos quando do total envolvimento do processo de ARA e implementação prática desses resultados. 


\section{PROPOSTA DE METODOLOGIA PARA EXECUCÃO DE ANÁLISE DE RISCO AMBIENTAL DE PROCESSO SIDERÚRGICO}

\subsection{CONCEITOS BÁSICOS}

A necessidade de se conhecer e avaliar as perdas acidentais partiu de iniciativas de norteamericanos e europeus logo após a Segunda Guerra Mundial (DE CICCO \& FANTAZZINI, 1985), objetivando unicamente o exame da possibilidade de redução de gastos com prêmios de seguros e o aumento da proteção da empresa frente a acidentes, bem como a redução do número de horas paradas por operário.

$\mathrm{Na}$ década de 60 , algumas empresas americanas, motivadas por problemas internos ou por solicitação das áreas militares, desenvolveram procedimentos de revisão de processos que asseguravam medidas preventivas contra acidentes que pudessem gerar perdas humanas ou financeiras.

A preocupação com o fato de que vários desses acidentes têm uma componente ambiental, e que não vinha sendo avaliada conscientemente, surgiu somente após vários acidentes cujas conseqüências foram drásticas e de repercussão mundial. Considerando alguns poucos acidentes de monta, como os de Feyzin (1966), Torrey Canyon (1967), Flixborough (1974), Beek (1975), Seveso (1976), etc., pode-se perceber que o envolvimento de pessoas e do meio não estava sendo devidamente equacionado. Entretanto, a partir dos anos 1970 ocorreu uma aceleração da consciência ecológica e prevencionista (JOURDAN, 1986), e, tendo em vista os graves acidentes ocorridos, envolvendo não somente as áreas da empresa como também a população vizinha e o meio ambiente, foi regulamentada no ano de 1982 a Diretiva da Comunidade Econômica Européia 82/501/CEE, mais conhecida como Diretriz de Seveso, que define e regulamenta, para os europeus, os riscos de uma unidade industrial, propondo a análise e a comunicação às autoridades e à comunidade, dos riscos inerentes ao processo avaliado (DE MARCHI,1991).

O objetivo central da Diretriz de Seveso era "melhor tratar os chamados acidentes maiores. Entende-se como acidente maior qualquer ocorrência, tal como emissão de fluídos tóxicos, incêndio, explosão, que seja conseqüência do desenvolvimento incontrolado da atividade industrial e que implique em risco grave iminente para o homem, dentro e fora da empresa, bem como para o meio ambiente" (FARBER, 1991).

A partir de então, houve uma evolução nos conceitos de riscos e das suas conseqüências ambientais, humanas, patrimoniais, financeiras, etc.. Inicialmente, foram tomadas atitudes isoladas, como por exemplo a proibição de produção, armazenamento, transporte e comercialização de alguns produtos químicos, considerando que os mesmos eram de alto risco ou perigosos. O fundamento legal para essa decisão baseou-se nos vários acidentes anteriores que formaram uma imagem negativa na população, suscitando uma pressão sobre os legisladores e as empresas. Posteriormente, foram estipulados critérios mais justos, e novas normas foram editadas para avaliar e quantificar os riscos inerentes de produtos e de processos, evoluindo até uma classificação desses riscos (PEREIRA \& PEDRO, 1993).

Na evolução da arte, foi necessária a definição dos termos utilizados. Nesse sentido porém, podese observar uma discordância entre alguns autores (FERNíCOLA, 1992), o que sugere a necessidade de uma ação concreta no sentido da normalização de conceitos e procedimentos técnicos.

No trabalho citado, pode-se encontrar quatro definiçסes diferentes de risco, que, somados aos de DE CICCO \& FANTAZZINI (1985) e de outros, mostram a divergência entre vários autores ou entidades.

As definições adotadas pela OMS (1978) consideram que o risco expressa: 
- o conceito estatístico e a freqüência esperada de um efeito nocivo produzido pela exposição a um agente químico;

- o termo usado para quantificar o dano, bem como a probabilidade de realização do evento, com conseqüências danosas.

SILANO (1984) considera risco como um conjunto de características diferentes que potencialmente predisponham um processo ou substância química à ocorrência de acidentes.

As definições adotadas por DE CICCO \& FANTAZZINI (1985) consideram risco como:

- uma probabilidade de possíveis danos dentro de um período específico de tempo ou ciclos operacionais;

- a incerteza quanto à ocorrência de um determinado evento;

- a chance de perda que uma empresa pode sofrer por causa de um acidente ou série de acidentes.

Finalmente, esses autores definem risco como sendo a probabilidade de ocorrência de danos à pessoa, propriedades e meio ambiente, em um determinado intervalo de tempo.

RICCI \& CIRILLO (1985) descrevem risco como uma função de três elementos básicos: causa da conseqüência, conseqüência e incerteza.

KASTENBERG \& SOLOMON (1985) expressam o conceito de risco como o envolvimento de uma combinação matemática de dois componentes: as conseqüências resultantes de um evento indesejável e a sua freqüência de ocorrência.

Nas definições adotadas pela IRPTC/UNEP (1986, apud FERNÍCOLA, 1992), risco representa:

- a freqüência esperada de um efeito indesejável que aparece por uma exposição específica a um poluente;

- um conceito matemático relativo à severidade de uma resposta adversa que aparece devido a uma exposição específica a uma substância química.

Já a IUPAC (1991) considera risco como:

- a probabilidade da ocorrência de um evento com conseqüências danosas, em função da exposição a um agente químico ou físico;

- a freqüência esperada de ocorrência de um evento danoso proveniente da exposição a um agente físico ou químico sob condições específicas.

Pode-se entender, contudo, que as definiçסes dadas para riscos concordam com a existência do dano (em qualquer de suas formas), da probabilidade de sua ocorrência e da freqüência com que ocorrem os acidentes. Os termos probabilidade e frequéncia inserem nas definições existentes o conceito estatístico e de quantificação do risco.

A evolução dos conceitos considera ainda os termos análise e avaliaçăo, que são sistematicamente empregados em estudos de risco.

Segundo KATES (1978, apud WHYTE \& BURTON, 1980), a determinação do risco ambiental possui três componentes que se interrelacionam: a identificaçăo do risco, a estimativa do risco e a avaliação do risco, e que estão descritos a seguir.

A determinação do risco ambiental ("risk assessment") é, segundo a UNEP (1986b), a análise integrada do risco e suas quantificações.

Identificaçăo de risco significa, segundo KATES (1978, apud WHYTE \& BURTON, 1980), o reconhecimento de que o risco existe, e trata-se de definir as suas características. Geralmente o risco existente é conhecido tempos antes de causar as consequências adversas. Em outros casos, a identificação do risco é um procedimento normal para revisar a possibilidade de algum dano, e espera-se que sua aplicação antecipe os eventos. 
A estimativa de risco já é uma determinação científica das características de risco, podendo-se, se possivel, aplicar técnicas quantitativas. Estas técnicas incluem a magnitude, a escala espacial, a duração e a intensidade das conseqüências adversas e as probabilidades associadas, assim como uma descrição da correlação entre as causas e seus efeitos. Os dois procedimentos citados podem necessitar de modelagens, monitoramentos, pesquisas e diagnósticos. propósito principal destes dois processos é entender o sistema ambiental e as formas complexas e o processo através do qual o risco existe.

O terceiro componente da determinação do risco, ainda segundo KATES (1978, apud WHYTE \& BURTON, 1980), é a avaliaçăo do risco ("risk evaluation"), na qual são feitos os julgamentos sobre a significância e a aceitabilidade das probabilidades e consequiências do risco identificado e estimado. Este conceito é o mesmo definido pela UNEP (1986b). Este último conceito é importante, pois é a partir dele que se formará a política de intervenção ou não na atividade existente, ou ainda em projeto, para minimizar a possibilidade de ocorrência do evento identificado e mensurado.

Segundo NORTH \& YOSIE (1987, apud FERNICOLA, 1992), a estimativa de risco é o uso de dados obtidos de fatos reais para definir os efeitos na saúde de indivíduos ou populações pela exposição a substâncias ou situações perigosas.

De acordo com PHILIPSON \& NAPADENSKY (1982), a análise de risco (AR) é a análise integrada dos riscos de um sistema ou instalação e sua importância em um contexto apropriado. Segundo os mesmos autores, a análise de risco consistiria das seguintes atividades:

- estimativa de riscos, que significa obter as probabilidades de conseqüências danosas através de dados obtidos do processo, armazenamento ou transporte de substâncias perigosas;

- avaliaçăo de riscos, que significa avaliar a aceitabilidade do risco em função de uma estimativa anterior.

SIMON (1984) considera que, para a análise de risco, quando esta envolve a variável ambiental, deve-se considerar o comportamento da substância química, assim como os agentes que atuam provocando suas transformaçōes no ambiente. Nessa sua consideração, o autor coloca como relevante para o estudo alguns fatores referentes à substância em estudo e sua interação com o meio ambiente:

- como a substância é introduzida no meio ambiente;

- disseminação da mesma no ecossistema da área de influência da fonte;

- ação dos agentes ambientais sobre a substância e as transformações pertinentes;

- impactos causados pela substância e seus subprodutos sobre os componentes do ecossistema local, sobre a saúde humana e sobre o patrimônio público e particular.

Segundo FANTAZZINI \& FARBER (1989), na análise de risco ambiental os riscos são apresentados com base nos possiveis impactos ambientais advindos das atividades humana $e$ empresarial, como os poluentes atmosféricos, do solo e das águas. Deve-se considerar ainda as causas prováveis identificadas e as medidas corretivas cabiveis.

O termo análise refere-se a um "procedimento técnico segundo determinados padrões, envolvendo as discussões sobre um problema sem escalonamento de valores". Já avaliaçăo "considera os resultados de uma análise a fim de os hierarquizar em função de objetivos estabelecidos" (PEREIRA \& PEDRO, 1992).

FERNICOLA (1992) propõe que o termo estimativa de riscos seja adotado, em detrimento do termo avaliaçăo de riscos, este muito mais usado pelos autores e técnicos da área. Para a autora, a estimativa de riscos é uma ferramenta importante para avaliar o perigo potencial da exposição humana a substâncias químicas de uso industrial. A dúvida semântica vem da adoção da tradução do termo original em inglês, "risk assessment".

Para PEREIRA \& PEDRO (1992), a avaliaçðo de riscos é um exame sistemático de uma instalação industrial, instalada ou em projeto, que visa identificar e formar uma opinião sobre ocorrências perigosas potencialmente sérias e suas respectivas conseqüências. Esse conceito é 
semelhante ao conceito adotado por NORTH \& YOSIE (1987, apud FERNICOLA, 1992) porém denominado como "estimativa de risco".

GREIG-SMITH (1992) considera que a análise de risco contém uma notável variedade de aplicações, podendo ser potencial ou ser presente e instantâneo.

Para BARNTHOUSE (1992), o propósito da caracterização do risco deve ser "a integração das informações obtidas de todos os componentes envolvidos e a comunicação aos dirigentes e tomadores de decisão, de uma forma compreensiva a não-especialistas e relevante para as decisões a serem tomadas".

A USEPA (1992) conceitua a análise de risco ecologico (ARE) como sendo a "probabilidade de ocorrência de efeitos ecológicos adversos como resultado de exposição a estressores relacionados às atividades antrópicas, tais como drenagem de áreas inundáveis ou emissão de poluentes, além dos efeitos sobre o equilíbrio do ecossistema".

Na realidade, o risco ecológico é aplicado para avaliar o efeito do estressor sobre os organismos, provocando desde alterações de comportamento até mutagênicas ou mesmo a letalidade, ou seja, desde efeitos crônicos até agudos, porém sempre relativos à ocorrência do estressor provocada, ou não, por um acidente com consequências ambientais.

A representação gráfica da figura 3 evidencia o objetivo de cada uma das análises de risco existentes e em especial a proposta neste trabalho, que é a análise de risco ambiental (ARA).

Na representação, pode ser observado que a análise de risco do processo (AR) fica limitada a identificar e analisar os riscos inerentes ao processo com conseqüências sobre a propriedade e a segurança e saúde do trabalhador. A análise de risco ambiental (ARA) é voltada à identificação e análise dos riscos do processo que possam provocar consequências sobre o meio ambiente, entendido como os meios sócio-econômico e biogeofísico. Já a análise de risco ecológico (ARE) se propõe a avaliar as consequências sobre a biota, especificamente.

Figura 3. Representação gráfica dos diferentes tipos de análise de risco (AR: análise de risco do processo; ARA: análise de risco ambiental; ARE: análise de risco ecológico)

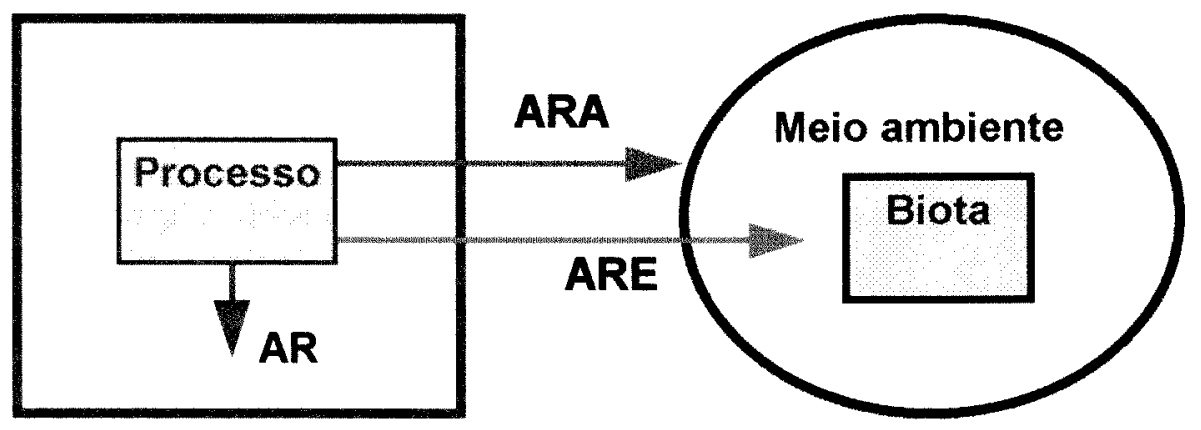

Foram consideradas, portanto, as várias definições existentes para os termos analise de risco e avaliação de risco. Considerou-se, também, a forma adotada para a sua aplicação no desenvolvimento desta tese. Nessa consideração, optou-se por uma composição entre as definições dadas por PHILIPSON \& NAPADENSKY (1982), por SIMON (1984) e por CONWAY(1982).

Pela definição dada por PHILIPSON \& NAPADENSKY (1982), análise de risco é a análise integrada dos riscos de um sistema ou instalação e sua importância em um contexto apropriado. 
Já para SIMON (1984) e para CONWAY (1982), a análise de risco deve envolver também o comportamento das substâncias químicas liberadas, assim como os agentes que atuam provocando suas transformações no ambiente.

Esses autores consideram relevantes, para a análise de risco, os seguintes tópicos:

- identificaçåo do risco, que significa conhecer os riscos existentes num projeto ou numa operação ou sistema já em pleno funcionamento;

- estimativa dos riscos, que significa obter as probabilidades de conseqüências danosas através de dados obtidos do processo, armazenamento ou transporte de substâncias perigosas;

- avaliaçăo de riscos, que significa avaliar a aceitabilidade do risco em função de uma estimativa anterior;

- forma como as substâncias são introduzidas no meio ambiente;

- a disseminação da mesma no ecossistema da área de influência da fonte;

- ação dos componentes ambientais sobre as substâncias e as transformações pertinentes;

- impactos causados pela substância e seus subprodutos sobre os componentes do ecossistema local, sobre a saúde humana e sobre o patrimônio público e particular.

No conceito deste trabalho, a análise de risco ambiental é a análise integrada de um sistema, instalação ou operação, segundo determinados critérios e padrões, que visa obter uma estimativa (de probabilidade e de frequiência) e uma avaliação (da magnitude e da aceitabilidade) dos riscos à saúde humana, ao patrimônio, às atividade sociais e econômicas è qualidade dos recursos ambientais.

A definição apresentada acima considera, evidentemente, a abrangência de um processo de análise que envolve múltiplas etapas e componentes tão variados quanto a produção de um bem e o controle ambiental. No entanto, cabe salientar alguns dos itens que poderão estar envolvidos no seu desenvolvimento ou no produto final da análise efetuada. Esses itens são relevantes não só para a prevenção do risco de acidentes, com conseqüências ambientais ou não, mas também para se ter à mão instrumentos de sensibilização dos responsáveis pelos empreendimentos e de seus diretores. $O$ estudo pode alertá-los quanto aos danos que determinada operação poderá vir a causar aos componentes sociais e econômicos de uma área ou região, bem como alertá-los quanto à sua responsabilidade civil na ocorrência de um evento indesejado.

Como pode ser concluido da definição proposta, a análise de risco ambiental é um exercício que, dada uma certa instalação, ou operação industrial ou não, se propõe a resolver certas situações apresentadas, tais como:

- quais eventos anormais poderão ocorrer durante a operação de um processo ou instalação?

- qual a probabilidade de ocorrência de um determinado evento indesejado?

- quais seriam as conseqüências (relativas à saúde humana, patrimônio, próprio ou de terceiros, e ao meio ambiente) caso ocorra esse evento?

- quais as ações a serem tomadas para eliminar ou minimizar os riscos encontrados?

- quais as açōes necessárias para eliminar ou minimizar as conseqüências de um determinado risco?

- qual a aceitabilidade, por parte do empresário e do poder público, de correr determinados riscos, envolvendo os componentes sociais, financeiros e ambientais?.

A simples observação dessas questões, consideradas como básicas na evolução de um estudo dos riscos de um processo qualquer, leva à avaliação da existência de duas características intrínsecas da ARA.

Considerações como quais os eventos possiveis, quais as consequências, e também a aceitabilidade de um risco têm uma variável absolutamente qualitativa. Embora para a avaliação das consequências possam ser aplicadas formulações matemáticas, numa primeira aproximação ela pode ser realizada através de conceitos não estatísticos. Por outro lado, a probabilidade de realização de um evento, sua freqüência, a abrangência ou influência numa determinada área e mesmo a determinação precisa das consequências desse evento, só poderão ser obtidas através 
de estudos quantitativos, baseados em fatos passados e em modelos físicos e em cálculos matemáticos.

Ambos os conceitos e técnicas são aceitos e aplicados amplamente nos estudos de análise de risco, porém com objetivos claramente definidos e distintos.

As análises qualitativas se aplicam a uma grande variedade de processos, porém se restringem a evidenciar o risco ou identificar as hipóteses de acidentes e classificá-lo quanto às suas consequências.

Na classificação mencionada, é possivel determinar a importância de um risco e compará-lo com outros riscos existentes no processo estudado. Esse fato pode dar ao gestor dos processos uma ordem de prioridade de ação na eliminação ou redução dos riscos de maior impacto. Como será discutido adiante, as técnicas disponíveis para esse tipo de análise são relativamente simples e de fácil aplicação, não requerendo, de um modo geral, nenhuma especialização do corpo técnico responsável pela sua realização.

Ao contrário das técnicas qualitativas, as análises de risco que envolvem a quantificação dos riscos de ocorrência de um evento, a sua área de abrangência, número de pessoas expostas, concentração de gases, formas e área de dispersão - aérea, no solo ou na água - freqüência com que o evento pode ser esperado, etc., envolvem complexas técnicas quantitativas. Por serem técnicas que se utilizam de recursos matemáticos e, por conseguinte, de modelos que se desenvolvem através de grandes fórmulas e equações só obtidas com o auxílio de computadores, tornam-se complexas e de difícil execução.

Na realidade, a dificuldade não está somente no desenvolvimento dos cálculos e modelos matemáticos - pois para isso existem programas específicos à venda no mercado internacional -, mas sim na obtenção dos dados que devem alimentar tais modelos e cálculos matemáticos. São dados relativos ao comportamento do clima de uma região, da composição de um determinado corpo receptor, seja ele o ar, a água ou mesmo o solo e seus aqǘferos subterrâneos, dados importantes como direção e velocidade dos ventos, altura de uma chaminé, relevo de uma região, velocidade das águas de um rio ou profundidade de um lago ou represa. Enfim, além dos dados do processo gerador do evento, há que se conhecer, minuciosamente, o ecossistema, a geologia, a hidrologia e os dados climatológicos do local, não esquecendo nunca os componentes social e econômico.

Nas técnicas quantitativas, são necessárias ainda as informações quanto ao material construtivo, fadiga de material, meia vida, estimativa de falhas, etc. Esses dados são relativamente difíceis de se obter no mercado nacional, ficando os técnicos das empresas na triste situação de depender da sua aquisição através de terceiros.

Portanto, os métodos disponiveis para a realização da ARA variam de uma simples lista de verificação a procedimentos extremamente complexos nos quais as cadeias dos eventos seqüenciais são examinados em grande detalhe, para assegurar que todos os aspectos do projeto, ou da operação onde uma falha possa ocorrer, foram exaustivamente revistos e a causa, 0 efeito e as consequências avaliadas.

Diferentes técnicas de análise de risco poderão ser apropriadas para um determinado estágio de um projeto, processo ou operação industrial. A decisão quanto a qual técnica aplicar está, até o momento, sendo tomada em função da facilidade de execução da mesma e dos dados necessários e disponíveis. Não há ainda um consenso entre os especialistas no assunto sobre qual deve ser a técnica aplicável a um processo específico. Alie-se ao exposto a necessidade de desenvolvimento de estudos complementares, que possibilitem o conhecimento de:

a) processo de produção e seus procedimentos;

b) grau de risco associado ao processo existente ou empreendimento futuro;

c) obtenção do histórico de acidentes em processos semelhantes (hipóteses acidentais);

d) determinação das conseqüências decorrentes das hipóteses determinadas;

e) determinação da aceitabilidade ou gerenciamento do risco; 
f) implantação de ações que eliminem ou minimizem os riscos sob gerenciamento, de acordo com os critérios de aceitabilidade.

A caracterização do processo tem por objetivo o conhecimento prévio das condições operacionais e construtivas de um equipamento ou operação; torna-se um item importante quando se trata da elaboração de uma análise de risco de um processo já implantado.

O segundo item diz respeito ao conhecimento da periculosidade da atividade a ser avaliada. Atualmente, existem vários critérios para se obter a classificação de uma fábrica quanto ao seu potencial de gerar acidentes ambientais. Segundo MAKARON (1992), os métodos utilizados permitem graduar o nivel de risco a partir dos principais fatores que intervêm no sistema, tais como:

- produtos manipulados ou armazenados, considerando: toxicidade, inflamabilidade, explosividade, reatividade, quantidades manipuladas;

- condições do processo e/ou armazenamento: vazão, pressão, temperatura, contenções e barreiras físicas, disponibilidade de ações emergenciais;

- sensibilidade das áreas sob influência do processo.

Evidentemente, essa classificação tem seus limites de aplicação, sendo indicadas para unidades de processo e armazenamento de substâncias tóxicas, inflamáveis e/ou explosivas, como por exemplo:

- de química orgânica e inorgânica;

- de destilação e refino de petróleo;

- de produção e tratamento de gases;

- de armazenamento permanente ou temporário.

A partir dessa etapa, deve ser providenciado o levantamento das "hipóteses acidentais" (item c). Essa tarefa inclui conhecer o processo/ operações, avaliar as possibilidades de acidentes através de análise de desenhos e práticas operacionais; obter um histórico de acidentes em unidades semelhantes, procurando relacionar os possiveis acidentes já ocorridos nessas unidades com aqueles identificados na análise dos desenhos e das práticas operacionais existentes; e, finalmente, a elaboração de uma ARA através de técnicas estruturadas, aplicáveis ao processo em evidência.

Devem ser também identificadas as possiveis conseqüências de ocorrência de um evento indesejado (item d), dando ensejo à conclusão do estudo através da análise da significância e da aceitabilidade do risco de acidente identificado e das formas de eliminar ou minimizar os riscos maiores ou inaceitáveis (item e). Nela, são definidos os procedimentos e os recursos para a redução da freqüência de ocorrência e das suas consequências, mantendo o risco determinado sob monitoramento e controle permanentes. A essa atividade final é dado o nome de gerenciamento de risco ambiental (item f).

As análises de risco de segurança existentes são aplicáveis a inúmeras situações e processos, não prevendo, necessariamente, as variáveis ambientais e de saúde humana como alvos a serem protegidos. Cabe ao administrador e ao técnico responsável pela elaboração da análise a inclusão dessas variáveis no estudo.

O conhecimento das técnicas mais comuns e tradicionais permite a esses tomadores de decisão a inserção dos aspectos ambientais no estudo, prevendo e até quantificando os danos possíveis se houver a ocorrência de um evento, catastrófico ou não.

Na tabela 1, resumem-se as técnicas a serem apresentadas, em função de sua complexidade e aplicabilidade.

A aplicação das técnicas descritas deve considerar o conhecimento prévio dos riscos inerentes ao processo avaliado, a partir inicial e empiricamente da determinação de uma categoria para os riscos presentes. Desse conhecimento inicial poderá haver uma decisão gerencial com relação à abrangência dos estudos a serem realizados. A tabela 2 evidencia as categorias em que podem ser enquadrados inicialmente os processos em avaliação. 
As categorias I e II são apropriadas para processos mecânicos e uso de substâncias perigosas, altamente controladas e em pequenas quantidades (menos de 50 litros). Na realidade, são realizadas, nessas categorias, uma triagem dos processos e a classificação dos riscos presentes.

A categoria III envolve um estudo mais complexo, não quantitativo, e auxilia na priorização das atividades que deverão ser adotadas para minimizar os riscos identificados no processo.

As técnicas de categoria IV são aplicadas visando quantificar os riscos identificados e determinar as conseqüências desse evento.

Uma avaliação mais resumida das quatro categorias propostas indicaria que, para as categorias I e II, está-se tratando de uma pré-avaliação do processo, enquanto que na categoria III está-se tratando da realização de uma pesquisa mais estruturada para determinação dos riscos presentes nos processos e, finalmente, na categoria IV, está-se tratando de avaliar a extensão dos efeitos e as conseqüências previstas na realização de um evento catastrófico.

Como já especificado, a escolha de técnica de análise de risco para um processo (processo como um todo, um determinado setor ou mesmo uma simples operação) vai depender da complexidade do processo/ operação e também do objetivo do trabalho (riscos humanos, patrimoniais ou ambientais). Em alguns casos, uma das atividades incluídas nas categorias I e II, previstas na tabela 2, poderia atender plenamente aos objetivos do gerenciador. Essas técnicas (categorias I e II), relativamente simples, podem até mesmo indicar a melhor técnica qualitativa ou quantitativa a ser aplicada, para se obter um aprofundamento do estudo. De qualquer forma, é sempre recomendável aplicar uma ou mais das técnicas previstas nessas categorias, a fim de verificar, no mínimo, o potencial de risco de acidente com conseqüências ambientais ou não, existentes na empresa. 
Tabela 1. Principais técnicas relativas a análise de risco, consideradas neste trabalho

\begin{tabular}{l|l|l|l}
\hline Avaliaçăo Preliminar & Técnicas simples de identificação de risco & Qualitativas & Quantitativas \\
\hline Análise histórica & Inspeção ("Check-list") & APR & Análise de árvore de falhas (AAF) \\
Diretiva de Seveso & Planilha de Segurança & What If/ "Check list" & Avallação de conseqüências \\
Indices Dow e Moud & Investigação de acidentes & HAZOP & Estimativa da freqüéncia \\
"Rapid ranking" & Incidentes críticos & AMFE & Análise de vulnerabilidade \\
"Hazard Study l" & & AAE & Estimativa de probabilidade \\
CATBRAS & & & \\
Manual do Banco Mundial & & & \\
\hline
\end{tabular}

Tabela 2. Resumo dos passos da aplicação da ARA

\begin{tabular}{c|l|l}
\hline Categoria & Técnica & \multicolumn{1}{c}{ Atividade } \\
\hline I & Avaliação preliminar & Classificação de unidade quanto ao risco de acidente e inventário de substâncias presentes \\
II & Técnicas simples & Avaliação de risco de acidentes maiores, históricos, inventários \\
III & Técnicas qualitativas & Avaliação dos riscos dos processos, emergências, propostas de controle \\
IV & Técnicas quantitativas & Avaliação de freqüência/consequências - quantificação dos riscos identificados \\
\hline
\end{tabular}




\subsection{PROCESSO DE OBTENÇÃO DO AÇO}

Em todo o mundo, mais de 700.000 .000 de toneladas de aço são produzidas anualmente. Nas sociedades desenvolvidas, a energia primária consumida nessa produção representa de 7 a $10 \%$ da energia nacional utilizada. A produção de aço não é uma atividade singular, mas envolve diferentes e complexas indústrias e com estágios sucessivos, dentro de uma mesma área. $\mathrm{Na}$ figura 4, pode ser observada a complexidade da industrialização do aço.

Segundo a IISI (1987), o processo siderúrgico começa a partir da extração do minério de ferro na natureza, sendo, a seguir, apresentada uma sintese sobre suas origens e sobre as principais etapas do processo, considerando-se também as informações da JISF (1989).

O ferro, um metal quimicamente ativo, de maneira geral e ordinária existe na natureza na forma de óxido. Está presente na crosta terrestre, porém na forma de óxidos de ferro $\left(\mathrm{Fe}_{2} \mathrm{O}_{3}\right)$ e magnetita $\left(\mathrm{Fe}_{3} \mathrm{O}_{4}\right)$.

De todos os depósitos de minério de ferro existentes, os mais importantes são aqueles de minério de ferro oxidado, que foram formados como sedimentos em grande quantidade nos mares primitivos. As chuvas, naquele período, eram fortemente ácidas, e o ferro, cuja presença era abundante na crosta terrestre, foi dissolvido pela chuva, sendo uma grande quantidade da água de lavagem carreada para o mar.

Um estudo recente revelou que há 3,5 bilhões de anos surgiram nos oceanos as algas verdeazuladas (cianofíceas), gerando oxigênio pela fotossintese. As cianofíceas são organismos comuns, encontradas em toda parte.

Nesses mares primitivos, as cianofíceas se multiplicaram, gerando quantidades maciças de oxigênio que, por sua vez, oxidaram o ferro dissolvido nas águas dos mares. Os ferros oxidados se acumularam no fundo do mar. A terra foi formada há cerca de 4,6 bilhões de anos atrás, e as algas tiveram seu aumento gradual há cerca de 3,5 bilhões de anos, quando então se formaram os sedimentos. Assim, o ferro continuou acumulando-se no fundo do mar em todo o globo terrestre, onde a sedimentação em grande escala ocorreu entre 2,6 bilhões e 1,8 bilhões de anos atrás.

Os depósitos de minério de ferro formados através desse processo estão distribuídos pelos continentes de todo o mundo. As reservas são muito vastas, o que possibilitou um fornecimento estável, para suprir a indústria siderúrgica. Os depósitos de minério de ferro, que são considerados atualmente como base da civilização moderna, podem ter resultado da atividade das algas cianofíceas nos tempos primitivos, o que mostra como a origem do ferro está relacionada com as características do meio ambiente do planeta.

A seguir, é descrita cada fase ou estágio da produção de aço.

- Mineraçăo - as principais operações de mineração envolvem a extração do minério de ferro e carvão. Outras operações, porém em menor escala, consistem na extração de sílica, manganês, níquel e cromo utilizados em ligas, e na obtenção de cal e minerais industriais para o processo e a fabricação de refratários.

- Preparaçăo da matéria prima - consta das seguintes operações :

transporte

armazenamento

misturas

.umectação do carvão (quando necessário)

beneficiamento de minérios

seleção

.coqueificação

sinterização/pelotização 
Figura 4. Fluxo de produção (segundo COSIPA, s/d).

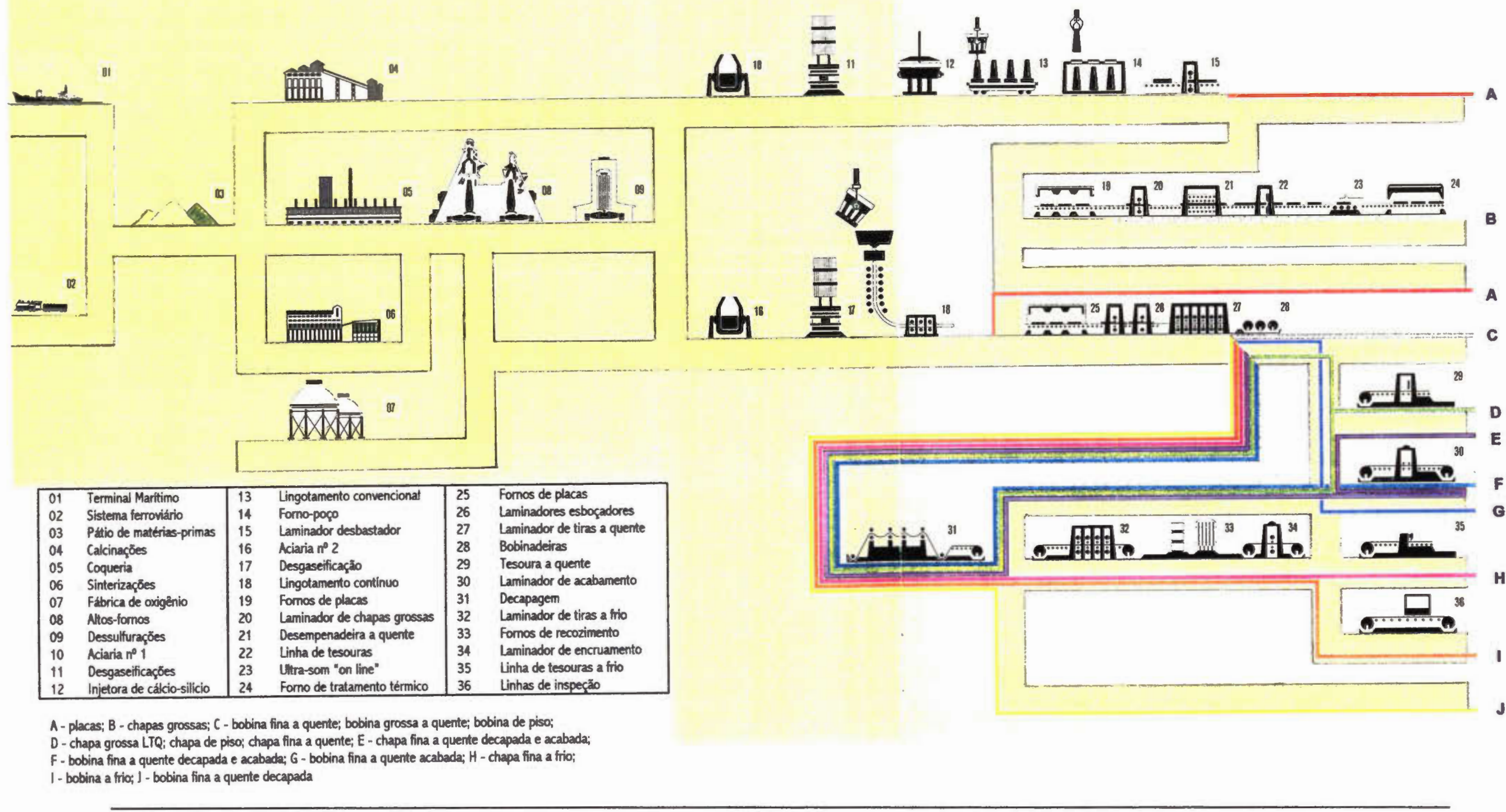


calcinação

.recuperação de sucatas

Devido ao fato do grande consumo de minério no alto-forno se dar na forma de finos, ou pelotas, esses minérios são misturados com as moinhas de coque e pulverizados com cal e em seguida passam pela sinterizaçăo, para se obter o sinter, que vai alimentar o alto-forno.

- Reduçăo (ferro gusa) e preparaçăo de ligas - consiste na produção de ferro e ligas sólidas ou líquidas, isto é, na redução direta do ferro por um sistema fluído ou de fornos, uso de altosfornos para a produção de gusa e metal líquido. Podem ser usados ainda os fornos elétricos para a fusão de ligas ferrosas.

- Aciaria - a produção de aço, usualmente feita em panelas com aplicação de oxigênio (BOF = Basic Oven Furnace) ou em fornos elétricos (EAF = Electric Furnace). A aciaria (BOF) converte metal líquido quente em aço, pela remoção do excesso de carbono, silicio, enxofre e outros elementos, considerados como impurezas.

- Produtos intermediários - a transformação, via solidificação, laminação ou moldagem do aço para fabricação de intermediários (lingotes, toras, tarugos, etc.), que passam de um para outro estágio ou são vendidos para outras indústrias.

- Laminaçăo a quente - envolve a inspeção dos "intermediários" para análise interna e superficial do produto, sua preparação, reaquecimento em forno-poço e laminação ou obtenção de chapas, para obtenção de diferentes tipos de produtos e aplicações (placas, chapas grossas, tarugos, laminados, folhas, barras, trilhos). Alguns desses produtos são comercializados.

- Laminaçăo a frio - fabricação de laminados a frio para obtenção de ângulos suaves ou seção. Laminados curvos ou retos para transformação em fio, corte ou uso em engenharia ou aplicação em chapas.

- Galvanizaçåo - consiste na cobertura superficial do produto usando banho metálico ou plástico, para venda direta.

- Fabricaçăo de produtos derivados do aço - galvanização, pintura, formatação, esmaltação, etc., para dar acabamento ao produto.

- Resíduos - reciclagem, comercialização ou disposição de resíduos sólidos.

As emissões típicas de um processo siderúrgico integrado estão relacionadas na figura 2, considerando no entanto que essas emissões são normalmente controláveis. Não constam nessa figura a armazenagem de produtos considerados perigosos, tais como ácidos, álcalis, combustiveis (líquidos e gasosos), residuos, etc.. 


\subsection{OS RISCOS DO PROCESSO SIDERÚRGICO}

\subsubsection{Principais processos que apresentam risco de acidentes com conseqüências ambientais}

As atividades industriais em uma siderúrgica são caracterizadas pelas quantidades e volumes de matérias-primas, insumos, produtos, subprodutos e resíduos, envolvidos nas operações rotineiras. De um modo geral, os processos aplicam ou geram subprodutos que apresentam algum tipo de risco ao meio ambiente. $O$ armazenamento, manuseio e destinação desses subprodutos, resíduos ou mesmo insumos é que irão classificar as operações como sendo de risco ou não.

Como considerado previamente, a realização de um evento com efeitos nocivos ao meio ambiente leva em conta principalmente a ocorrência de vazamentos ou derrames de gases ou liquidos que possam ultrapassar as contenções secundárias. A indústria siderúrgica gera ou utiliza em seus diversos processos gases tóxicos e/ou combustíveis e produtos químicos que são usados como insumo nos processos ou obtidos como subprodutos. A quantidade desses produtos estocados ou armazenados num determinado instante é muito grande, variando, evidentemente, em função do porte da fábrica e número e tipos de processos instalados. De qualquer maneira, é considerável a probabilidade de ocorrência de vazamentos ou derrames de produtos líquidos e/ou gasosos. Essa preocupação deve orientar os gerentes das áreas de segurança do trabalho, meio ambiente e seguros.

Também o uso constante de vasos sob pressão, contendo não só ar sob pressão, mas geralmente substâncias que são classificadas como explosivas, devem aumentar a preocupação desses gestores. Evidentemente, esse tipo de evento - explosão - tem maiores conotações do tipo patrimonial e de risco para os trabalhadores. Como já mostrado, os danos ambientais advindos de uma explosão são normalmente restritos e de pequeno efeito.

A existência de pátios de armazenamento de óleos combustiveis, de gás liqüefeito de petróleo ou natural, usados em fornos ou caldeiras, e os gases gerados em altos fornos, aciarias e coquerias e estocados em enormes gasômetros, tudo aliado a uma grande rede de distribuição desses gases e combustiveis, é motivo de sobra para que seja considerada a possibilidade de ocorrência de incêndios de grandes conseqüências. Mais uma vez, a realização desse tipo de evento pode ter pouca importância ambiental, podendo ficar restrita a perdas humanas e materiais.

É evidente que o risco deve apresentar uma graduação, em função de variáveis tais como: quantidade, explosividade, inflamabilidade, toxicidade; sistemas de prevenção implantados; treinamento de pessoal envolvido nas operações com essas substâncias/processos, enclausuramento, etc.. Entretanto, essas variáveis somente serão abordadas quando da realização de um estudo que as leve em consideração, através da quantificação, avaliações e testes e possiveis conseqüências.

No escopo deste trabalho é considerada a possibilidade de um determinado processo vir a causar algum problema ambiental. Assim sendo, foram relacionados na tabela 3 , a seguir, aqueles processos siderúrgicos que, por possuírem algum tipo de substância que possa gerar um acidente maior, atendem a essa premissa. Nessa tabela, é relacionada a unidade considerada como de risco e o motivo dessa classificação inicial. É importante salientar, uma vez mais, que esta classificação é feita em função da substância presente na unidade.

Para melhor entendimento do proposto na tabela 3, explica-se, a seguir, o conteúdo de cada uma das colunas apresentadas.

\section{- principal evento previsto:}

É representado pelos eventos que podem vir a ocorrer quando da realização do acidente. Tais eventos podem ser: explosão, incêndio e vazamento. Esses eventos poderão ocorrer isoladamente ou não. Para efeito deste trabalho, é levada em conta a realização do evento causador ou base. As ocorrências subsequentes ("efeito dominón) são complexas e somente 
Tabela 3. Principais processos que apresentam risco de acidentes com conseqüências ambientais

\begin{tabular}{|c|c|c|c|c|}
\hline Processo & $\begin{array}{l}\text { Elementos quo } \\
\text { caracterizam o } \\
\text { risco }\end{array}$ & $\begin{array}{l}\text { Proforl } \\
\text { evento } \\
\text { previsto }\end{array}$ & $\begin{array}{l}\text { Atonuantes } \\
\text { possivels }\end{array}$ & $\begin{array}{l}\text { Principal molo } \\
\text { fisico atetado }\end{array}$ \\
\hline Mineraçăo & explosivos & explosăo & - & - \\
\hline Sinterizaçăo & $\begin{array}{l}\text { gases de combustāo } \\
\text { (GCO) }\end{array}$ & incéndio & enclausurado & - \\
\hline Coqueria & GCO & $\begin{array}{l}\text { incéndio } \\
\text { vazamento }\end{array}$ & $\begin{array}{l}\text { pressão negativa } \\
-\end{array}$ & fauna/ flora terrestres \\
\hline Carboquímicos & $\begin{array}{l}\text { GCO e hidrocarbonetos } \\
\text { produtos químicos }\end{array}$ & $\begin{array}{l}\text { incêndio } \\
\text { vazamento } \\
\text { vazamento }\end{array}$ & $\begin{array}{l}- \\
-\end{array}$ & $\begin{array}{l}\text { fauna/ flora terrestres } \\
\text { solo e água }\end{array}$ \\
\hline Gasômetros & GAF e GCO & $\begin{array}{l}\text { explosăo } \\
\text { incêndio } \\
\text { vazamento } \\
\end{array}$ & $\begin{array}{l}- \\
- \\
-\end{array}$ & $\begin{array}{l}- \\
\text { faunal flora terrestres }\end{array}$ \\
\hline Alto-forno & $\begin{array}{l}\text { GAF/ oxigênio } \\
\text { GAF e pó } \\
\text { óleo combustivel } \\
\text { metal liquido }\end{array}$ & $\begin{array}{l}\text { incéndio } \\
\text { vazamento } \\
\text { explosăo } \\
\text { vazamento } \\
\text { derrames }\end{array}$ & $\begin{array}{l}\text { enclausurado } \\
\text { enclausurado } \\
\text { - } \\
\text { - }\end{array}$ & $\begin{array}{l}\text { fauna e flora terrestres } \\
\text { solo e água } \\
\end{array}$ \\
\hline Fábrica de oxigênio & $\begin{array}{l}\text { oxigênio/ amónia } \\
\text { Amônia }\end{array}$ & $\begin{array}{l}\text { incêndio } \\
\text { vazamento }\end{array}$ & - & fauna/ flora terrestres \\
\hline Sopradores & GCO/ pressåo & $\begin{array}{l}\text { explosăo } \\
\text { incêndio }\end{array}$ & - & 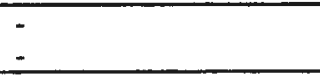 \\
\hline Dessulfuração & $\begin{array}{l}\text { gás acetileno } \\
\text { gás acetileno }\end{array}$ & $\begin{array}{l}\text { explostáo } \\
\text { incéndio }\end{array}$ & - & - \\
\hline Aciaria & $\begin{array}{l}\text { metal liquido } \\
\text { gás/ pressâo }\end{array}$ & $\begin{array}{l}\text { derrames } \\
\text { explosấo } \\
\text { incéndio } \\
\text { vazamento }\end{array}$ & $\begin{array}{l}\text { enclausurado } \\
\text { enclausurado } \\
\text { enclausurado }\end{array}$ & $\begin{array}{l}- \\
- \\
- \\
\text { somente área interna }\end{array}$ \\
\hline Forno posco & $\begin{array}{l}\text { óleo combustível } \\
\text { GCO }\end{array}$ & $\begin{array}{l}\text { vazamento } \\
\text { vazamento }\end{array}$ & $\begin{array}{ll}- \\
-\end{array}$ & $\begin{array}{l}\text { solo e água } \\
\text { fauna/ flora terrestres }\end{array}$ \\
\hline $\begin{array}{l}\text { Forno de } \\
\text { aquecimento }\end{array}$ & $\begin{array}{l}\text { gás combustivel } \\
\text { óleo combustivel }\end{array}$ & $\begin{array}{l}\text { explosāo } \\
\text { vazamento } \\
\text { vazamento }\end{array}$ & $\begin{array}{l}\text { enclausurado } \\
\text { enclausurado } \\
\text { - }\end{array}$ & $\begin{array}{l}\text { so área interna } \\
\text { só área interna } \\
\text { água/ solo interno }\end{array}$ \\
\hline Laminaçăo a quente & oleo hidráulico & vazamento & - & água/ solo interno \\
\hline Decapagem & $\begin{array}{l}\text { Acidos } \\
\text { Desengraxantes }\end{array}$ & $\begin{array}{l}\text { vazamento } \\
\text { vazamento }\end{array}$ & - & $\begin{array}{l}\text { água/ solo interno } \\
\text { água/ solo interno }\end{array}$ \\
\hline Fornos recozimento & gases tóxicos & vazamento & enclausurado & só área interna \\
\hline Estanhagem & produtos químicos & vazamento & - & solo interno/ aqua \\
\hline Zincagem & produtos químicos & vazamento & - & solo interno/ áqua \\
\hline Fundiçăa & Gases & $\begin{array}{l}\text { explosăo } \\
\text { vazamento } \\
\end{array}$ & $\begin{array}{l}\text { enclausurado } \\
\text { enclausurado }\end{array}$ & só área interna \\
\hline Tanques & $\begin{array}{l}\text { Óleo combustivel } \\
\text { produtos químicos } \\
\text { Gases }\end{array}$ & $\begin{array}{l}\text { vazamento } \\
\text { vazamento } \\
\text { explosåo } \\
\text { incéndio } \\
\text { vazamento }\end{array}$ & $\begin{array}{l}- \\
- \\
-\end{array}$ & $\begin{array}{l}\text { solo/ água } \\
\text { solo/água } \\
- \\
\text { - fauna/ flora terrestres }\end{array}$ \\
\hline $\begin{array}{l}\text { Sistema de } \\
\text { tratamento de ar }\end{array}$ & gases/pó & explosão & $=$ & - \\
\hline $\begin{array}{l}\text { Sistema de } \\
\text { tratamento de água }\end{array}$ & produtos químicos & vazamento & - & água e solo \\
\hline Resíduos sólidos & produtos químicos & vazamento & - & água e solo \\
\hline Almoxarifado & produtos químicos & vazamento & - & água e solo \\
\hline Caldeiras & gases/ pressaa & explosäo & - & - \\
\hline Calcinaçåo & $\begin{array}{l}\text { gases/ pressáo } \\
\text { óleo combustivel }\end{array}$ & $\begin{array}{l}\text { explosăo } \\
\text { vazamento }\end{array}$ & - & $\begin{array}{l}- \\
\text { águal solo e faunal flora } \\
\text { terrestres }\end{array}$ \\
\hline $\begin{array}{l}\text { Estaçăo } \\
\text { transformadora }\end{array}$ & óleo hidráulico & vazamento & - & solo/água \\
\hline
\end{tabular}

GCO: gás de coqueria; GAF: gás de alto-forno

poderão ser melhor definidas durante a realização do estudo de avaliação do risco de acidente, implementando a técnica de análise de risco adotada e induzindo a conexão de outras técnicas de 
previsão de conseqüências primárias e secundárias (ação direta sobre o processo ou sistema e ação sobre o meio ambiente - considerado aqui como um todo).

- atenuantes possíveis dos riscos apresentados:

Foram considerados, como atenuantes possiveis dos riscos apresentados anteriormente, os fatores que reconhecidamente minimizam os riscos abordados. Dentre tais fatores atenuantes, podem ser relacionados:

- enclausuramento do processo - atenuante de explosões;

- inexistência de fontes de ignição/ incompatibilidade das substâncias presentes - atenuantes de incêndios;

- área de exposição/ estado físico da substância/ incompatibilidade de substâncias/ fatores de diluição - atenuantes de vazamentos de substâncias tóxicas;

- existência de programa de prevenção e análise de risco - atenuante genérico dos riscos previstos.

\section{- principal meio afetado}

Foram considerados os elementos que certamente sofrerão com a realização do evento indesejado. Neste caso, o dano ambiental será considerado com exclusividade. Como critério, foi adotada a exposição do elemento físico onde os efeitos poderão provocar danos devido à dificuldade de recuperação e não em função de sua proteção. $O$ fator proteçăo poderá ser abordado na realização do estudo, quando forem propostas as medidas de minimização do risco e prevençäo dos efeitos negativos do evento identificado.

Os elementos ambientais relevantes são descritos como rotas de exposição e mecanismos de transporte e contato do meio biogeofísico e sócio-econômico com as substâncias quimicas oriundas da realização de um evento indesejado. Os mecanismos de transporte servem para mobilizar as substâncias perigosas geradas no evento, até estarem disponiveis sobre os sistemas suscetiveis (população humana ou outro sistema biológico).

Inúmeros fatores compöem as vias de exposição ou os mecanismos de transporte de uma substância no meio biogeofísico. Os meios físicos mais expostos são as águas (superficiais e subterrâneas) e o solo, e os fatores intervenientes são aqueles próprios dos meios considerados, podendo ser citados os dados climatológicos, topográficos, hidrogeológicos, geológicos, hidrodinâmicos, difusão gasosa, etc..

A tabela 4 traz uma composição entre as vias de exposição e os mecanismos de transporte das substâncias perigosas. A mesma tabela traz, ainda, os principais fatores que interferem diretamente no mecanismo de transporte.

\subsubsection{Substâncias envolvidas nos processos siderúrgicos que apresentam risco de acidentes}

Segundo as definições adotadas pelos autores e profissionais que estudam ou elaboram projetos de avaliação de eventos indesejáveis, o conceito de risco envolve a "medida da probabilidade e a magnitude de um efeito adverso, incluindo aí danos, doenças, perdas econômicas e mortes" (OMS, 1978). Evidentemente, esse risco inclui a possibilidade da ocorrência de um fato catastrófico, como por exemplo a explosão ou incêndio de um prédio. Esses riscos, embora indesejáveis, podem ter conotações ambientais pouco significativas, como já visto anteriormente. Para efeito de reconhecer e prevenir problemas ambientais, os riscos mais importantes são aqueles que possibilitam a ocorrência de vazamentos ou derrames de substâncias quimicas, produtos ou mesmo rejeitos químicos industriais. Essa premissa impõe o conhecimento de toda substância ou produto químico e também dos residuos sólidos perigosos que são usados, manuseados, estocados ou transportados em uma fábrica. Dessa forma, todos esses agentes, que podem ser químicos, biológicos e até mesmo físicos, possuem um potencial de risco que deve ser quantificado e/ou qualificado. 
Tabela 4. Fatores físicas e quimicos que atuam sobre as vias de exposiçáo e os mecanismos de transporte

\begin{tabular}{|c|c|c|c|}
\hline \multirow[t]{2}{*}{ Vias de exposiçăo } & \multirow{2}{*}{$\begin{array}{l}\text { Mecanismo de } \\
\text { transporte }\end{array}$} & \multicolumn{2}{|c|}{ Fatores Atuantes } \\
\hline & & Químicos & Físicos \\
\hline \multirow{4}{*}{ Ar } & Volatilizaçăo & & \\
\hline & Aerossobis & $\begin{array}{l}\text { Solubilidade das substâncias } \\
\text { em meios líquidos }\end{array}$ & ventos, chuvas \\
\hline & $\begin{array}{l}\text { Deposiçăo de material } \\
\text { particulado }\end{array}$ & & $\begin{array}{l}\text { tamanho da partícula; chuva, } \\
\text { ventos; estabilidade atmosférica }\end{array}$ \\
\hline & Ventos & - & $\begin{array}{l}\text { direçăo, velocidade; } \\
\text { estabilidade atmosférica }\end{array}$ \\
\hline \multirow{3}{*}{ Biota } & Bioacumulaçăo & Solubilidade das subståncias & temperatura, pressio \\
\hline & Migraça & - & - \\
\hline & Bioconcentraçăo & Solubilidade das substâncias & temperatura, pressăo \\
\hline Água & $\begin{array}{l}\text { Drenagens, galerias } \\
\text { Rios } \\
\text { Córregos } \\
\text { lençol fredtico } \\
\text { chuvas } \\
\text { escoamento superficial }\end{array}$ & $\begin{array}{l}\text { Solubilidade das substáncias } \\
\text { Concentraçăo dos poluentes } \\
\text { Persistencia } \\
\text { Degradaçấ } \\
\text { Toxicidade }\end{array}$ & $\begin{array}{l}\text { Vazáo } \\
\text { Volume } \\
\text { Represamento } \\
\text { Infiltracaso }\end{array}$ \\
\hline Solo & $\begin{array}{l}\text { Aterros } \\
\text { Disposiçóes acidentais } \\
\text { derrames } \\
\text { infiltraçáo } \\
\text { uso de biocidas } \\
\text { uso de cortetivos do solo }\end{array}$ & $\begin{array}{l}\text { Solubilidade } \\
\text { Compostos orgånicos } \\
\text { Concentragâa de poluentes }\end{array}$ & $\begin{array}{l}\text { Porosidade } \\
\text { Profundictade } \\
\text { cobertura vegetal } \\
\text { nivel do lençol subterrâneo }\end{array}$ \\
\hline
\end{tabular}

Em uma indústria siderúrgica, existem várias substâncias classificadas como perigosas, independentemente de seu porte e do parque industrial que possui. Essas substâncias devem ser conhecidas e seu potencial de causar um problema ambiental estudado e mitigado. Uma indústria siderúrgica normalmente emprega ou produz várias substâncias, como por exemplo as listadas na tabela 5. Essas substâncias poderão ser geradas em maior ou menor quantidade, dependendo evidentemente do porte das fábricas instaladas e do processo produtivo aplicado na fábrica.

Várias unidades e sistemas, como por exemplo: fábrica de oxigênio, carboquimicos, decapagem, zincagem, etc., não estão presentes em todas as fábricas do setor. Algumas indústrias siderúrgicas mantêm somente umas poucas atividades típicas do ramo, como, por exemplo, somente laminam a quente ou a frio, ou mesmo só praticam a extrusão ou fiação. Nesses casos, o emprego de substâncias perigosas pode ser mínima, mas năo deixa de existir o risco.

Como já citado, as substâncias perigosas são aquelas que contêm um potencial de causar algum tipo de problema, ambiental ou não, quando liberadas de forma não controlada. Nesse contexto, vários resíduos industriais são incluídos como perigosos, pois podem contribuir significativamente para um dano ambiental, se não ocorrer seu correto manuseio, estocagem, transporte ou destinaçăo.

\subsubsection{Caracterizaçăo e classificaçăo das substancias perigosas normalmente presentes em uma unidade siderúrgica}

A caracterização e a classificação de uma substância normalmente é feita considerando o perigo que ela representa para os trabalhadores. A sua classificaçăo é normalmente extrapolada para a determinaçăo das implicaçōes na saúde pública, baseada nas fontes de dados disponíveis sobre efeitos à saúde específicos à comunidade, e outras informaçőes toxicológicas e médicas.

Evidentemente, quando se trata de meio ambiente, outros fatores devem ser considerados, como por exemplo o efeito de substâncias químicas em animais e corpos receptores (solo/água), pois podem ocasionar problemas ambientais. 
Tabela 5. Relaçăo das principais substâncias, produtos e resíduos industriais, classificados como perigosos (potencial de causar algum dano), normalmente presentes numa unidade siderúrgica (seg. PROCTOR et. al., 1988)

\begin{tabular}{|c|c|c|c|}
\hline Substancia & $\begin{array}{l}\text { Estado } \\
\text { fisico }\end{array}$ & $\begin{array}{l}\text { Aplicação } \\
\text { (P/N/R/sp) }\end{array}$ & Risco predominante \\
\hline Oleo combustivel & $\mathrm{L}$ & IN & $\mathrm{V} / \mathrm{I}$ \\
\hline Oleo hidráulico & $\bar{L}$ & IN & $V / 1$ \\
\hline Oleo solúvel & $\bar{L}$ & IN & $\mathrm{V} / \mathrm{I}$ \\
\hline Gás de coqueria & G & SP/IN & V/I/E \\
\hline Gás de Alto Forno & $G$ & SP/IN & V/I/E \\
\hline Carbeto de cálcio & $\mathrm{S}$ & IN & $E$ \\
\hline Amônia & LG & IN & VII/E \\
\hline Argônio & G & IN & $E$ \\
\hline Nitrogênio & $\mathbf{G}$ & IN & $E$ \\
\hline Oxigênio & $\mathbf{G}$ & IN & $E$ \\
\hline Acetileno & $\mathbf{G}$ & IN & $E$ \\
\hline Benzeno & $L$ & SP & IN \\
\hline Tolueno & L & SP & IN \\
\hline Xileno & $L$ & SP & IN \\
\hline Amônia anidra & $\mathrm{s}$ & SP & $\mathbf{V}$ \\
\hline Fenol & L & SP & V \\
\hline O-cresol & $L$ & SP & V \\
\hline P-cresol & $\mathrm{L}$ & SP & $\bar{V}$ \\
\hline Naftaleno & $\bar{L}$ & SP & $\mathrm{V}$ \\
\hline Creosoto & $\mathrm{L}$ & SP & $\mathrm{V}$ \\
\hline Piche & $\mathbf{L}$ & SP & $\mathrm{V}$ \\
\hline Dióxido de enxofre (1) & $\mathbf{G}$ & $\mathbf{R}$ & $\mathbf{V}$ \\
\hline Sulfato de sódio & S & IN & - \\
\hline Sulfato ferroso & $\mathbf{s}$ & IN/SP & - \\
\hline Ácido sulfúrico & $\mathrm{L}$ & IN/R & $\mathbf{V}$ \\
\hline Ácido clorídrico & $\mathrm{L}$ & IN & $\overline{\mathrm{V}}$ \\
\hline Soda & s & IN/R & V \\
\hline Gás liqüefeito de petróleo & $\mathrm{L}$ & IN & IN/E \\
\hline Gás natural (1) & $\bar{L}$ & IN & INIE \\
\hline PCB & $L$ & IN/R & $\mathrm{V}$ \\
\hline Amianto & S & $\mathbf{R}$ & - \\
\hline CFC & $L$ & $\mathbf{R}$ & $\mathbf{V}$ \\
\hline Borras oleosas & LS & $\mathbf{R}$ & $\mathrm{V}$ \\
\hline Solventes & $L$ & IN/R & $\mathrm{V}$ \\
\hline Lamas da aciaria/alto forno & $\mathbf{s}$ & $\mathbf{R}$ & V \\
\hline Escória do alto forno & $\mathbf{S}$ & $\mathbf{R}$ & V \\
\hline $\begin{array}{l}\text { Aditivos de resíduos de: } \\
\text { zincagem ( } \mathrm{Zn} / \mathrm{Cr} / \mathrm{Cd})\end{array}$ & LS & IN/R & V \\
\hline estanhagem $(\mathrm{Zn} / \mathrm{Cr} / \mathrm{Cd})$ & LS & IN/R & $\mathrm{V}$ \\
\hline Percloroetileno & $L$ & IN/R & V \\
\hline Cloreto de metileno & $\mathrm{L}$ & IN/R & V \\
\hline Triclorometano & $\underline{L}$ & IN/R & $\mathbf{V}$ \\
\hline Tricloroeteno & L & IN/R & V \\
\hline Ácido nítrico & L & IN & $\bar{V}$ \\
\hline
\end{tabular}

(1) não armazenado
SP: subproduto
L: líquido
I: incêndio
R: resíduo
P: produto
IN: insumo
S: sólido
V: vazamento
G: gás
E: explosão 
Os testes ou trabalhos efetivos que permitem aos pesquisadores inferir que uma determinada substância apresenta risco de causar morte ou algum tipo de estresse a um grupo ou espécie de animal ou vegetal, são realizados em laboratório e avaliam o potencial de provocar um problema, pelo estudo do efeito de diferentes concentrações aplicadas por massa ou número de organismos expostos. Essas concentrações (ou doses) administradas variam em efeito, desde niveis subletais (como por exemplo mutagênico) até a letalidade (efeito agudo).

A consideração a ser feita refere-se à transferência desse efeito para o meio ambiente, haja visto que, na natureza, a substância é submetida a interações cujos efeitos podem ser antagônicos, de diluição, aditivos ou mesmo de transformação.

Tendo em conta somente que a substância não sofra efeitos sinergisticos ou antagônicos, e que sua concentração no meio seja submetida somente aos efeitos físicos de diluição e transporte, é possivel que mesmo doses muito pequenas provoquem reações nos meios biológicos, não havendo, portanto, um valor limite determinado para os efeitos ambientais de determinadas substâncias.

Os estudos de toxicidade que avaliam as respostas de organismos a diferentes concentrações consideram ainda a possibilidade de concentrações muito pequenas não provocarem efeito adverso (NOEL - NO Adverse Effects Leve). Neste caso, os pesquisadores propõem a existência de uma concentração limite, eliminando as dúvidas (incertezas) do efeito sobre os organismos expostos.

Para efeito deste trabalho, que é analisar o risco de realização de um evento com conseqüências ambientais, considerando que a realização do evento seja, principalmente, a liberação incontrolada de uma substância química perigosa, e que as conseqüências ambientais sejam aqueles danos causados aos meios biogeofísico e sócio-econômico, as substâncias químicas foram classificadas de acordo com seus efeitos sobre o meio ambiente e a partir de uma composição de efeitos já determinados. Esses dados podem ser encontrados na NB 10004 Classificação de Residuos Sólidos, da NFPA (National Food Processors Association).

A tabela 6 relaciona as principais substâncias presentes normalmente em uma siderúrgica, e os dados que a classificam como perigosa ou não. Os dados foram obtidos em: ITII (1981), PARMEGGIANI (1983), SAX (1984) e PROCTOR et al. (1988).

\subsubsection{Identificação de fonte de dados de acidentes, na indústria siderúrgica nacional}

O processo siderúrgico apresenta várias etapas onde é alta a probabilidade de ocorrer um acidente de proporção considerável. Os acidentes que podem levar a uma situação de dano ambiental são comuns em qualquer processo e normalmente poderiam ser relatados. No entanto, não é o que ocorre, principalmente na área da siderurgia brasileira. Uma consulta realizada pelo autor em 1992 através do IBS (Instituto Brasileiro de Siderurgia), a todas as empresas associadas, revelou que em nenhuma das fábricas que responderam ao questionário havia ocorrido qualquer tipo de acidente que houvesse tido conseqüências ambientais (incêndio, explosão ou vazamento). Embora o questionário tenha deixado claro quais acidentes deveriam ser relatados, acabou ocorrendo a omissão dos mesmos. Era sabido, na época, que haviam ocorrido alguns acidentes; porém, não foram relatados nesse questionário.

O fato de não se ter obtido respostas confiáveis deve-se a falhas internas de documentação e registro de eventos nas indústrias nacionais. A padronização dos registros, a definição do gerenciamento desses registros e de quem deve fazê-lo não é uma preocupação dos técnicos da área. Normalmente, são encontrados dados a respeito do número de pessoas acidentadas e a forma em que se deu o acidente/ incidente, porém não é relatada a circunstância do acidente nem suas conseqüências ambientais.

Alguns acidentes maiores poderiam ser resgatados através dos registros das seguradoras, quando estas são acionadas. Entretanto, mais uma vez, a pesquisa desses dados é, normalmente, dificultada, pela explicação de que existe confidencialidade dos registros efetuados. 
Tabela 6. Caracterizaçăo e classificaçăo das substâncias presentes numa usina siderúrgica

\begin{tabular}{|c|c|c|c|c|c|c|}
\hline \multirow[t]{2}{*}{ Substancia } & \multirow[t]{2}{*}{ Rieco predominante } & \multirow{2}{*}{$\begin{array}{c}\text { Calor de } \\
\text { combustio (1) }\end{array}$} & \multirow{2}{*}{$\begin{array}{l}\text { Ponto de } \\
\text { fulgor }\left({ }^{\circ} \mathrm{C}\right)\end{array}$} & \multirow{2}{*}{$\begin{array}{c}\text { Ponto de } \\
\text { ebullgio }\left({ }^{\circ} \mathrm{C}\right)\end{array}$} & \multicolumn{2}{|c|}{ Toxkeldade } \\
\hline & & & & & NFPA & $\mathbf{L T}$ \\
\hline Oleo mineral & $\mathrm{V} n$ & 17.0 & 193 & 360 & 0 & $5 \mathrm{mg} / \mathrm{m}^{3}$ \\
\hline Dióxido de carbono (gás de coquerla) & VMIE & - & - & - & - & $5000 \mathrm{ppm}$ \\
\hline Dióxido de carbono (gás de Alto Forno) & V//E & - & - & - & - & 5000 ppm \\
\hline Carbeto de cálcio & $\bar{E}$ & 9.1 & - & - & 1 & - \\
\hline Amónia & VA/E & 8.0 & gats & 33 & 3 & $25 \mathrm{ppm}$ \\
\hline Nitrogennio & $\bar{E}$ & - & - & $-195,5$ & - & - \\
\hline Oxogénio & $E$ & - & - & -183 & - & - \\
\hline Acetileno & $\bar{E}$ & 20.7 & gás & -84 & 1 & - \\
\hline Benzeno & IN & 17.3 & -11 & 80 & 2 & $1 \mathrm{ppm}$ \\
\hline Tolueno & IN & 17.4 & 4,4 & 110 & 2 & $100 \mathrm{ppm}$ \\
\hline Xileno & IN & 17.6 & 27,2 & 144 & 2 & 100 ppm \\
\hline Amónia anidra & $\mathrm{V}$ & - & 651 & 33,5 & - & $25 \mathrm{ppm}$ \\
\hline Fend & V & 13.4 & 79 & 181 & 3 & $5 \mathrm{ppm}$ \\
\hline O-cresol & $V$ & - & - & - & - & $5 \mathrm{ppm}$ \\
\hline P-cresol & $\mathrm{v}$ & - & - & - & - & $5 \mathrm{ppm}$ \\
\hline Naftaleno & $\bar{v}$ & 16.7 & 79 & 218 & 2 & $10 \mathrm{ppm}$ \\
\hline Piche & $\bar{v}$ & - & 482 & - & - & $10 \mathrm{ppm}$ \\
\hline Dióxido de enxofre (1) & $\mathrm{v}$ & 0.0 & gás & 10 & 2 & $2 \mathrm{ppm}$ \\
\hline Ácido sulfúrico & $\mathrm{V}$ & - & - & 315 & - & $1 \mathrm{ppm}$ \\
\hline Acido cloridrico & $\mathrm{V}$ & - & - & -85 & - & $35 \mathrm{ppm}$ \\
\hline Soda & $\bar{v}$ & - & - & 1390 & - & $2 \mathrm{mg} / \mathrm{m}^{3}$ \\
\hline Cal & $\mathbf{V}$ & - & - & 580 & - & $2 \mathrm{mg} / \mathrm{m}^{3}$ \\
\hline Gás liquiefeito de petróleo & IN/E & - & 420 & - & - & $1000 \mathrm{ppm}$ \\
\hline Gás natural (1) & IN/E & - & 420 & - & - & $1000 \mathrm{ppm}$ \\
\hline$\overline{P C B}$ & $\mathrm{~V}$ & - & - & - & 3 & $0,5 \mathrm{mg} / \mathrm{m}^{3}$ \\
\hline Amianto & - & - & - & - & - & 0,5 fibras $/ \mathrm{ml}$ \\
\hline CFC & $\overline{\mathbf{V}}$ & - & - & - & - & $1000 \mathrm{ppm}$ \\
\hline $\begin{array}{l}\text { Aditivos de reaiduos de: } \\
\text { Zincagem (Zn/Cr/Cd) }\end{array}$ & v & - & - & - & - & $50,50,5 \mathrm{mg} / \mathrm{m}^{3}$ \\
\hline Estanhagem $(\mathrm{Zn} / \mathrm{Cr} / \mathrm{Cd})$ & $\mathrm{V}$ & - & - & - & - & $50,50,5 \mathrm{mg} / \mathrm{m}^{3}$ \\
\hline Percloroetileno & $\mathbf{v}$ & - & - & - & - & $50 \mathrm{ppm}$ \\
\hline Cloreto de metileno & $\mathbf{v}$ & - & 556 & 40,1 & - & $500 \mathrm{ppm}$ \\
\hline Triclorometano & $\mathbf{v}$ & - & - & - & - & $10 \mathrm{ppm}$ \\
\hline Tricloroeteno & $\bar{v}$ & - & - & - & - & $50 \mathrm{ppm}$ \\
\hline Ácido nitrico & $\bar{V}$ & - & - & 86 & - & $2 \mathrm{ppm}$ \\
\hline
\end{tabular}

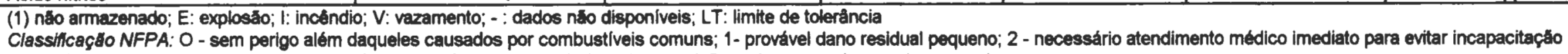

temporéria; 3 - materiais que causam dano sério temporário ou residual; 4 curta exposiçắo pode causar dano maior ou morte. 
Vários acidentes puderam ser observados pelo autor, durante o período em que trabalhou em empresa siderúrgica e manteve contato com outras fábricas do setor. Acidentes com explosões e incêndios de média a grande proporção ocorreram em unidades tais como aciaria, sopradores, altos-fornos, unidades de subprodutos, cortes de sucata, laminações, armazenamento de resíduos, tratamento térmico, etc.. Mesmo operações envolvendo manutenção ocorreram com significativo vazamento de produtos químicos para o meio ambiente, tendo-se verificado 0 comprometimento de corpos receptores da região. Os registros feitos para alguns desses eventos não consideraram os danos ambientais ou sociais; apenas levaram em conta o dano patrimonial, a fim de obter ressarcimento, através do seguro, do bem envolvido e da perda de produção. Quando houve danos ao trabalhador, o acidente foi investigado a fim de evidenciar a responsabilidade, em caso de futuras indenizações.

\subsubsection{Histórico de acidentes}

Os trabalhos técnicos apresentados em congressos, seminários, reuniōes, etc., com a participação de profissionais da área siderúrgica e correlatas, não têm apresentado relatos de acidentes em processos que tenham conseqüências ambientais. Os trabalhos normalmente limitam-se a registrar os problemas ambientais advindos de operações e processos industriais e as maneiras e técnicas de combatê-los ou controlá-los. Muita ênfase é dada ao estudo dos impactos ambientais de operaçōes já existentes ou em modificação. $O$ risco de ocorrer um acidente ou o relato do acidente e suas conseqüências não vem sendo contemplado pelos técnicos do setor.

Evidentemente, essa situação é extensiva aos registros existentes não é cobrada a comunicação da ocorrência de acidentes/incidentes com conseqüências ambientais dentro das unidades de produção. Alguns órgãos de controle estadual de meio ambiente possuem a autoridade fornecida pela legislação ambiental para exigir o cumprimento da comunicação de acidentes/ incidentes com agravos ambientais, tais como derrames de óleo e substâncias químicas no solo ou no mar, liberação de gases/vapores tóxicos, etc.. Alguns decretos ou normas estipulam até o prazo de 24 horas para essa comunicação, sob a pena de multa em caso de omissão (São Paulo, Bahia e Rio de Janeiro, por exemplo).

A comunicação da ocorrência de um evento tem dois objetivos imediatos: açăo de controle e ação de recuperaçăo, e dois outros, considerados mediatos e tão importantes quanto os primeiros, açăo por danos e formaçăo de banco de dados.

Dos Estados com tradição industrial, possuidores de usinas siderúrgicas ou indústrias químicas com produção e armazenamento de substâncias perigosas, somente em São Paulo existe um banco de dados estruturados e de livre consulta. Trata-se do CADAC - Cadastro de Acidentes Ambientais, com registros de acidentes remontando a 1983. O CADAC é um cadastro dos acidentes ocorridos no Estado de S. Paulo, atendidos pela CETESB ou não, e gerenciado pela Divisão de Tecnologia de Riscos Ambientais da CETESB - Companhia de Tecnologia de Saneamento Ambiental.

A consulta ao CADAC, atualizado até 07 de outubro de 1997, evidencia o registro de 134 acidentes no periodo compreendido entre 23 de fevereiro de 1983 e 01 de setembro de 1997 . 0 cadastro resume todo tipo de acidente ocorrido, tanto na indústria como no transporte ou no armazenamento de um produto, fornecendo, ainda, quando possivel, a quantidade da substância envolvida no evento.

$\mathrm{Na}$ tabela 7 apresenta-se uma compilação dos dados existentes no CADAC, colocando em evidência o tipo de acidente maior que foi registrado durante os anos de existência do sistema, as principais substâncias que estiveram envolvidas nos acidentes/incidentes, onde ocorreram tais eventos e o meio que foi afetado pelos eventos. Pela tabela, é possivel obter alguns números que permitem uma avaliação das principais ocorrências no Estado de São Paulo, e que foram acompanhadas pela CETESB. Já na tabela 8 são relacionadas as substâncias envolvidas nos acidentes/incidentes, fornecendo ainda o número de vezes em que isso aconteceu. 
Para efeito de avaliação, algumas substâncias foram agrupadas sob uma só denominação, visando facilitar a elaboração da tabela e a compreensão dos eventos registrados. Desta forma, as substâncias englobam:

oleos: óleo diesel, óleo combustível (sem classe), nafta, gasóleo, óleo lubrificante, petróleo, óleo mineral:

ácidos: ácido clorídrico, ácido sulfúrico, ácido nítrico, ácido sulfâmico;

solventes e outras substâncias orgânicas ou năo: gasolina (ne), dicloropropilanilida $(3800 \mathrm{~kg})$, cloreto de vinila $(100 \mathrm{l})$, metacrilato de metila (ne), tricloreto de fósforo $(50 \mathrm{l})$, cianeto de cobre (ne), resina (ne), xantato de celulose (ne), TDI (35000 I), acrilato de etila (120 I), acetona (600 I), anilina $(600 \mathrm{I})$, benzina (ne), hipoclorito de sódio (30 ton), hidrossulfito de sódio (50 I), acrilonitrila (ne), mercaptanas $(80 \mathrm{l})$, glicerina (ne), cloreto de benzoila $(200 \mathrm{l})$, estireno $(260 \mathrm{~kg})$, dietilpropiona (15 I), oxicloreto de fósforo $(1 \mathrm{l})$, hidróxido de amônio (ne), dióxido de nitrogênio (ne), terebintina (ne), sulfeto de hidrogênio (ne), tolueno (ne), tintas (ne), fenol (ne), cola (ne), acrilamida (ne), ciclohexilamina (ne) [Obs.: a abreviatura "ne" significa que a quantidade não foi estimada].

A composição de várias substâncias sob a denominação "solventes e outras substâncias" deveuse às pequenas quantidades registradas e o nümero de vezes em que aparecem no cadastro. Cada uma delas é registrada somente uma vez.

O número de acidentes registrados no CADAC chega a 134, no período de 14 anos. Felizmente, somente um caso foi catastrófico, com a morte de três pessoas, motivada pelo vazamento de sulfeto de hidrogênio. Aconteceram cinco casos com registro de intoxicações pelas emanações de: acetona $(600 \mathrm{l})$, ácido clorídrico, gás cloro (37 pessoas intoxicadas) e glicerina (vapores). Duas outras situações com vazamento de produtos químicos levaram a danos ambientais, com morte de gado por ingestão de água contaminada com cianeto de cobre que atingiu um córrego, e de peixes no rio Cubatäo (SP), ocorrida pelo derrame de hidróxido de amônio. Vale lembrar que o acidente ocorrido em Cubatão devido a vazamento de combustivel em dutos da PETROBRÁS, seguido de incêndio, registrou, oficialmente, 92 mortes.

O SINCAAM - Sistema Nacional de Cadastro de Acidentes Ambientais, que registra os acidentes no Brasil, atualmente sediado na CETESB, em S. Paulo, encontra-se desatualizado. Segundo o Eng. ${ }^{\circ}$ Ricardo Rodrigues Serpa, da Divisão de Tecnologia de Riscos Ambientais, da CETESB (comunicação pessoal), este cadastro é alimentado através de informaçōes colhidas na imprensa, ou recebidas de outras fontes.

Vários são os bancos internacionais de dados de acidentes/incidentes. Esses bancos relatam de maneira sucinta os principais tipos de acidentes, substâncias envolvidas, processo envolvido e danos observados, além dos dados complementares como data, local, nome da unidade, etc..

A consulta a esses bancos normalmente é feita adquirindo-se parte dos dados que possam interessar na forma de listagem ou mesmo através de meios eletrônicos.

Segundo PEREIRA \& PEDRO (1992), os principais bancos de dados disponiveis são:

- ITACA - Banco de Dados de Incidentes Industriais e de Transporte (TRR - Itália). A identificação do acidente é feita através do levantamento de dados sobre o mesmo, como: número da informação, data, local, país, empresa, fatalidades, baixas, danos, tipo de indústria, evento, causa, fatores contribuintes, tipo de instalação, local de instalação, substâncias envolvidas, e uma descrição da ocorrência.

- IFP - Banco de Dados de Acidentes no Mar e de Poluição (IFP - França). O sistema é composto por dois bancos de dados, sobre: vazamentos de óleo com todos os tipos de embarcaçōes, e acidentes ocorridos em plataformas e sistemas de produção fixos ou móveis.

- FACTS - Sistema de Informação Técnica de Falhas e Acidentes (Paises Baixos). Possui dados sobre acidentes, classificados em dez grupos, de acordo com o tipo de ocorrência: fenômenos naturais (terremotos, enchentes, relâmpagos, etc.), operações indevidas (pressa, desatenção, etc.), utilização de equipamentos inadequados, condições anormais (sobrepressão, sobrecarga, etc.), ambientes impróprios (falta de ventilação, sujeira, etc.), falhas do sistema (oscilação, interrupção, etc.), falhas mecânicas (choque, queima, etc.), falhas elétricas (queda 
Tabela 7. Dados obtidos no CADAC da CETESB, atualizado até outubro de 1997. I: incêndio; E: explosăo; V: vazamento; N.: número de acidentes; Pr: produçăo; Ar: armazenamento; Tr: transporte; h/e: homem/empresa

\begin{tabular}{|c|c|c|c|c|c|c|c|c|c|c|c|c|}
\hline \multirow[t]{2}{*}{ Ano } & \multicolumn{3}{|c|}{$\begin{array}{l}\text { Tlpo de } \\
\text { ecidente. }\end{array}$} & \multirow[t]{2}{*}{ Substancla } & \multirow[t]{2}{*}{$\mathrm{M}^{\circ}$} & \multicolumn{3}{|c|}{ Processo } & \multicolumn{4}{|c|}{ Melo aletado } \\
\hline & I & $\bar{E}$ & $\mathbf{V}$ & & & Pr. & Ar. & Tr. & bous & rolo & Ar & We \\
\hline 1983 & - & - & 2 & bleo & 2 & - & 1 & 1 & 2 & - & - & - \\
\hline 1985 & - & 1 & 2 & bleo & 3 & - & 3 & - & 3 & - & - & - \\
\hline 1986 & - & 3 & 4 & $\begin{array}{l}\text { ácidos } \\
\text { solventes } \\
\text { residuos }\end{array}$ & $\begin{array}{l}2 \\
2 \\
3\end{array}$ & 2 & 5 & - & 1 & 3 & 3 & - \\
\hline 1987 & 3 & - & 11 & $\begin{array}{l}\text { ácidos } \\
\text { solventes } \\
\text { óleo } \\
\text { amónia } \\
\text { năo identificados }\end{array}$ & $\begin{array}{l}4 \\
5 \\
2 \\
1 \\
2 \\
\end{array}$ & 4 & 9 & 1 & 4 & 5 & 3 & 2 \\
\hline 1988 & 1 & 1 & 5 & $\begin{array}{l}\text { resíduos } \\
\text { solventes } \\
\text { não identificados }\end{array}$ & $\begin{array}{l}3 \\
2 \\
2 \\
\end{array}$ & 3 & 3 & 1 & 3 & 2 & 2 & 1 \\
\hline 1989 & 3 & 1 & 11 & $\begin{array}{l}\text { cloro } \\
\text { solventes } \\
\text { bleo } \\
\text { năo identificados } \\
\text { ácidos }\end{array}$ & $\begin{array}{l}1 \\
5 \\
3 \\
5 \\
1\end{array}$ & 10 & 4 & 1 & 4 & 2 & 1 & 8 \\
\hline 1990 & 2 & 2 & 8 & $\begin{array}{l}\text { residuos } \\
\text { ácidos } \\
\text { solventes } \\
\text { năo identificados } \\
\text { cloro } \\
\end{array}$ & $\begin{array}{l}3 \\
2 \\
4 \\
2 \\
1 \\
\end{array}$ & 3 & 8 & 1 & 4 & 2 & 5 & 1 \\
\hline 1991 & 1 & 2 & 2 & $\begin{array}{l}\text { óleo } \\
\text { năo identificados } \\
\text { ácidos } \\
\text { solventes } \\
\end{array}$ & $\begin{array}{l}2 \\
1 \\
1 \\
1 \\
\end{array}$ & 4 & 1 & - & 1 & - & 3 & 1 \\
\hline 1992 & 3 & - & 11 & $\begin{array}{l}\text { solventes } \\
\text { cloro } \\
\text { BHC } \\
\text { ácidos } \\
\text { näo identificados } \\
\text { amónia } \\
\text { óleo } \\
\end{array}$ & $\begin{array}{l}5 \\
1 \\
1 \\
1 \\
2 \\
1 \\
3 \\
\end{array}$ & 5 & 7 & 2 & 4 & 1 & 4 & 5 \\
\hline 1993 & 1 & - & 8 & $\begin{array}{l}\text { óleo } \\
\text { solventes } \\
\text { ácidos } \\
\text { năo identificados } \\
\text { amônia } \\
\text { resíduos } \\
\end{array}$ & $\begin{array}{l}2 \\
2 \\
1 \\
1 \\
2 \\
1\end{array}$ & 2 & 6 & 1 & 2 & 4 & 2 & 1 \\
\hline 1994 & 2 & - & 2 & $\begin{array}{l}\text { GNP } \\
\text { resíduos } \\
\text { solventes } \\
\text { não identificados }\end{array}$ & $\begin{array}{l}1 \\
1 \\
1 \\
1 \\
\end{array}$ & 2 & 2 & - & - & - & 2 & 2 \\
\hline 1995 & 1 & - & 5 & $\begin{array}{l}\text { ácidos } \\
\text { GLP } \\
\text { solventes } \\
\text { residuos }\end{array}$ & $\begin{array}{l}2 \\
1 \\
1 \\
2\end{array}$ & 3 & 2 & 1 & - & 3 & 1 & 2 \\
\hline 1996 & 1 & 2 & 24 & $\begin{array}{l}\text { solventes } \\
\text { ácidos } \\
\text { óleo } \\
\text { não identificados } \\
\text { amónia }\end{array}$ & $\begin{array}{c}5 \\
5 \\
5 \\
10 \\
2 \\
\end{array}$ & 4 & 23 & - & 10 & 4 & 3 & 10 \\
\hline 1997 & - & - & 9 & $\begin{array}{l}\text { ácidos } \\
\text { solventes } \\
\text { óleo } \\
\text { resíduos } \\
\text { gás } \\
\end{array}$ & $\begin{array}{l}2 \\
2 \\
1 \\
2 \\
2 \\
\end{array}$ & 7 & 2 & - & 3 & 3 & 2 & 1 \\
\hline
\end{tabular}


Tabela 8. Relaçăo das substâncias envolvidas nos acidentes registrados no CADAC CETESB, atualizado até outubro de 1997.

\begin{tabular}{l|c}
\hline \multicolumn{1}{c|}{ Evento } & Números obtidos \\
\hline Substâncias envolvidas em acidentes comunicados: & 24 \\
- óleos combustiveis & 22 \\
- ácidos inorgânicos & 32 \\
- solventes e outras substâncias & 06 \\
- amônia & 03 \\
- cloro & 15 \\
- resíduos industriais & 27 \\
- não identificados & 01 \\
- BHC & 01 \\
- gás natural & 01 \\
- gás de petróleo (GLP) & 02 \\
- gás de refinaria & 49 \\
N.o de acidentes ocorridos no processo & 76 \\
N.o de acidentes ocorridos no armazenamento & 09 \\
N.o de acidentes ocorridos no transporte & 18 \\
N.o de casos de incêndios & 12 \\
N.o de casos de explosões & 104 \\
N. de casos de vazamentos & 41 \\
N.o de vezes em que recursos hidricos foram atingidos & 29 \\
N.o de vezes em que o solo foi atingido & 31 \\
N.o de vezes em que a atmosfera foi atingida & \\
N.o de vezes em que o homem/patrimônio foram & 33 \\
\hline atingidos &
\end{tabular}

de energia, eletricidade estática), fenômenos físicos (ondas de vento, radiação), danos lentos (corrosão, desgaste de material, etc.).

- VERITEC - Banco de Dados de Acidentes em Mar Aberto (Países Baixos). Informações sobre acidentes marítimos, abrangendo os seguintes tipos de ocorrências: explosões, incêndios, colisões e naufrágios de embarcações, vazamentos de produtos químicos. Para acidentes em plataformas de exploração, os dados englobam também outras informações: tipos de poços, dimensões da plataforma, localização geográfica, sistemas de controle e segurança, etc.. 0 VERITEC possui, ainda, algumas informaçōes sobre sinalização, dutos submarinos e produção submarina.

- ADRS - Sistema de Informações de Ocorrências Anormais (ISPRA - Itália). O ADRS é composto por diversos bancos de dados integrados (França, Itália, Suécia, EUA), contendo informações sobre eventos que geraram ou poderiam ter gerado acidentes em instalaçōes nucleares, cabendo destacar: liberação ou explosão de materiais radioativos, degradação de sistemas radioativos (líquido refrigerante, combustivel, pressão ou temperatura do sistema, etc.), deficiências de projeto, controle, operação e aspectos de segurança, efeitos externos.

- MHIDAS - Major Hazard Incident Data Service (Reino Unido). Informaçőes sobre os grandes acidentes industriais com produtos perigosos, coletados ao longo dos últimos trinta anos. As informações encontram-se armazenadas em 24 campos diferentes, podendo ser recuperadas das mais diversas formas, de acordo com as necessidades do usuário. Dentre as principais aplicaçōes do MHIDAS, pode-se destacar: análise estatística de acidentes, elaboração de legislações especificas e normas de procedimento, subsídios para planos de emergência, alterações em projetos de processos industriais, etc..

- SONATA - Summary of Notable Accident in Technical Activities (Tema - Itália). Identifica os acidentes, através dos seguintes tópicos: número de referência, local, país, data, tipo de acidente, substância envolvida, quantidade, fatalidades, baixas, danos, extensão, tipo de indústria, tipo de processo, descrição do acidente. Deste banco, segundo informações verbais do Eng. ${ }^{\circ}$ Ricardo R. Serpa, com relação à indústria siderúrgica, pode-se estimar que os acidentes se resumem conforme definido na tabela 9, a seguir. 
Tabela 9. Dados de acidentes do banco de dados SONATA, de 1956 a 1987, envolvendo a indústria siderúrgica (seg. SERPA, comunicação pessoal, 1997)

\begin{tabular}{|c|c|c|c|c|}
\hline Acidente & Processo & Substancia & Mortos & Feridos \\
\hline Vazamento & conversor & gás (argónio) & 2 & 5 \\
\hline Explosấa & aciaria & & $=$ & - \\
\hline Vazamento & aciaria & Aço & - & - \\
\hline Vazamento & fundiçăo & & - & 1 \\
\hline Vazamento tóxico & tanques & ácido nítrico & - & 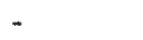 \\
\hline Incendio & carboquímicos & Benzeno & 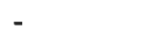 & \\
\hline Vazamento & carboquímicos & Antraceno & 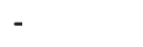 & 1 \\
\hline $\begin{array}{l}\text { Incêndio } \\
\text { Incêndio }\end{array}$ & carboquímicos & Benzeno & - & - \\
\hline Incêndio & carboquímicos & Naftaleno & - & - \\
\hline $\begin{array}{l}\text { Vazamento } \\
\text { explosăo confinada }\end{array}$ & $\begin{array}{l}\text { transporte interno } \\
\text { forno de coqueria }\end{array}$ & $\begin{array}{l}\text { Benzeno } \\
\text { gás de coqueria }\end{array}$ & $\begin{array}{l}1 \\
19\end{array}$ & - \\
\hline $\begin{array}{l}\text { explosăo confinada } \\
\text { Vazamento (aás) }\end{array}$ & $\begin{array}{l}\text { forno de coqueria } \\
\text { carbouímicos }\end{array}$ & $\begin{array}{l}\text { gás de coqueria } \\
\text { Benzeno }\end{array}$ & Năo det. & Nåo det. \\
\hline Vazamento & tanques de manut. & licor amoniacal & 1 & - \\
\hline Incêndio & transporte interno, & Benzeno & 1 & 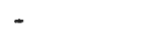 \\
\hline Vazamento & carboguímicos & vaoc & 1 & 1 \\
\hline Vazamento & coqueria (transportador) & fluido hidráulico & - & 1 \\
\hline Vazamento & carboquímicos & sulfeto de & - & 1 \\
\hline & & hidrogênio & - & ? \\
\hline $\begin{array}{l}\text { explosão confinada } \\
\text { Explosáo }\end{array}$ & forno de coqueria & $\begin{array}{l}\text { gás de coqueria } \\
\text { oxioênio }\end{array}$ & $\begin{array}{c}- \\
-\end{array}$ & $\begin{array}{l}2 \\
1\end{array}$ \\
\hline $\begin{array}{l}\text { Explosáo } \\
\text { Incêndio }\end{array}$ & $\begin{array}{l}\text { fundiçăa } \\
\text { forno de coqueria }\end{array}$ & carvăo de coque & - & \\
\hline Vazamento tóxico & manutençáo de tubos & gás & 1 & 5 \\
\hline Incêndio & coqueria & carvăo & - & 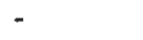 \\
\hline Explosăo & aciaria & & 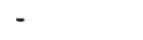 & - \\
\hline Explosáo & conversor & água, gusa & - & 1 \\
\hline
\end{tabular}

\subsubsection{Principais riscos identificados em banco de dados}

De um modo geral, os números coletados no banco de dados de acidentes industriais da CETESB evidenciam que a saúde humana e o patrimônio foram bastante impactados quando comparados com os meios biogeofísicos considerados. Mais de $24 \%$ dos acidentes registrados tiveram como conseqüência danos à saúde e ao patrimônio. O percentual restante $(76 \%)$ refere-se a impactos ao solo, atmosfera e corpos hídricos.

A figura 5 representa uma comparação entre a quantidade de acidentes com vazamento de substâncias químicas, explosões e incêndios, ocorridos entre janeiro de 1983 e setembro de 1997. Nela, é possível constatar a elevada quantidade (104) de casos de vazamentos (liberação de gases ou derrames de líquidos) comparativamente a explosões (12) e incêndios (18). Deve-se considerar que, para efeito de compilação dos dados para este trabalho, foram registrados somente os eventos finais, não havendo preocupação com o evento inicial, como por exemplo 0 vazamento de um gás inflamável, que veio a redundar em incêndio - o evento registrado foi 0 incendio.

A diferença na quantidade de acidentes com vazamentos em relação aos demais eventos possiveis em casos de acidentes maiores comprova as afirmaçōes iniciais deste trabalho, quando destaca que esse tipo de acidente é o que mais ocorre em atividades industriais, atingindo, via de regra, o meio ambiente.

Esses acidentes, conforme o banco de dados da CETESB (CADAC), ocorreram principalmente no armazenamento dos produtos. Nessa operação, foram registrados 76 casos de acidentes. $\mathrm{Na}$ figura 6 apresenta-se, além desse registro, a quantidade de acidentes documentados no processo industrial, com 49 casos, evidenciando serem essas duas atividades as que mais provocam acidentes. O transporte interno às fábricas (dutos, manuseio, caminhōes, tambores, etc.) representou 9 eventos. 
Figura 5. Quantidade de acidentes envolvendo incêndio, explosăo e vazamentos (segundo o CADAC, de 1983 a 1997)

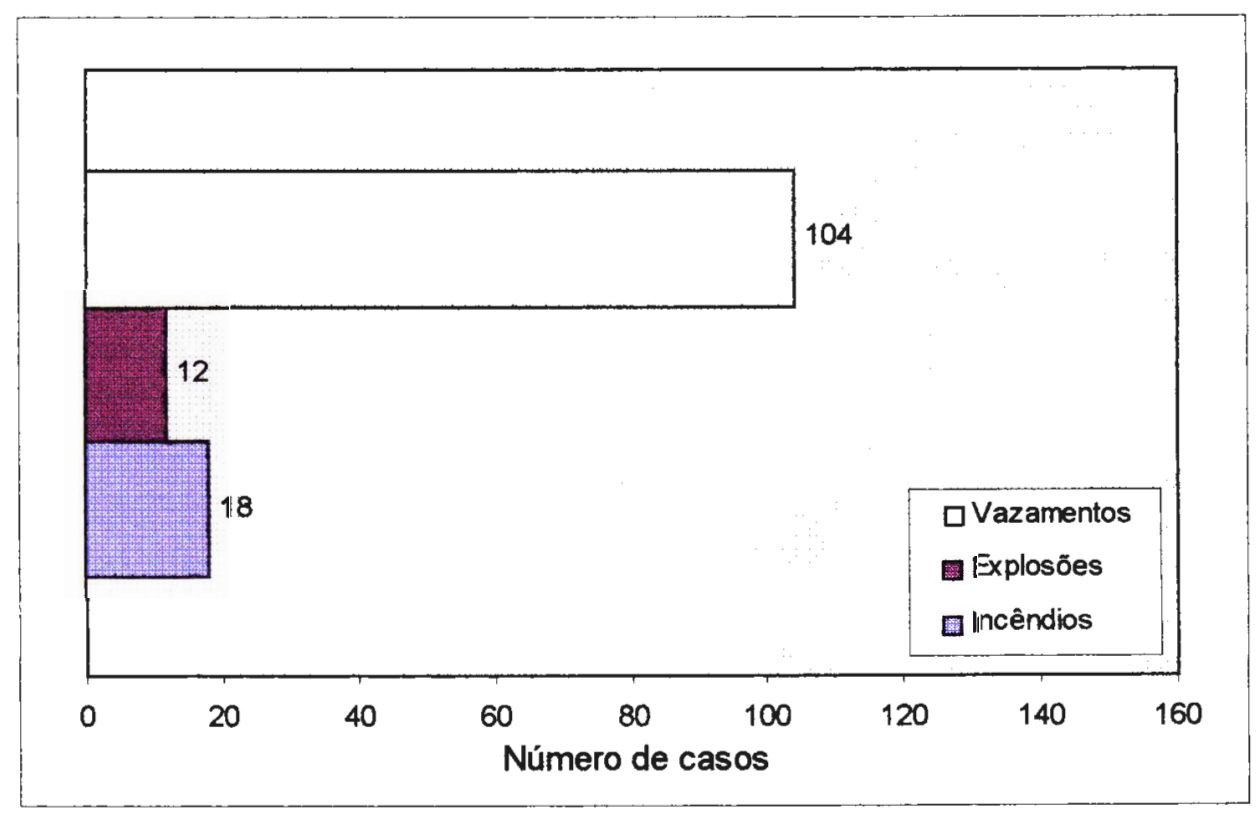

Os registros do CADAC indicam ainda os principais meios atingidos pelos eventos ocorridos. $A$ figura 7 representa a freqüência com que os diferentes meios foram atingidos pelos diversos acidentes ocorridos. Com a constatação de que a grande maioria dos acidentes ocorreram com vazamentos (gases e líquidos), é lícito verificar que as águas (superficiais e subterrâneas) foram as que maior número de vezes (41) estiveram expostas. A qualidade do ar na região onde houve o acidente foi alterada pela ocorrência de 31 eventos com liberação de gases, e o solo recebeu o impacto da efetivação de 29 acidentes.

Figura 6. Quantidade de acidentes segundo os locais de ocorrência, registrados no CADAC, de 1983 a 1997

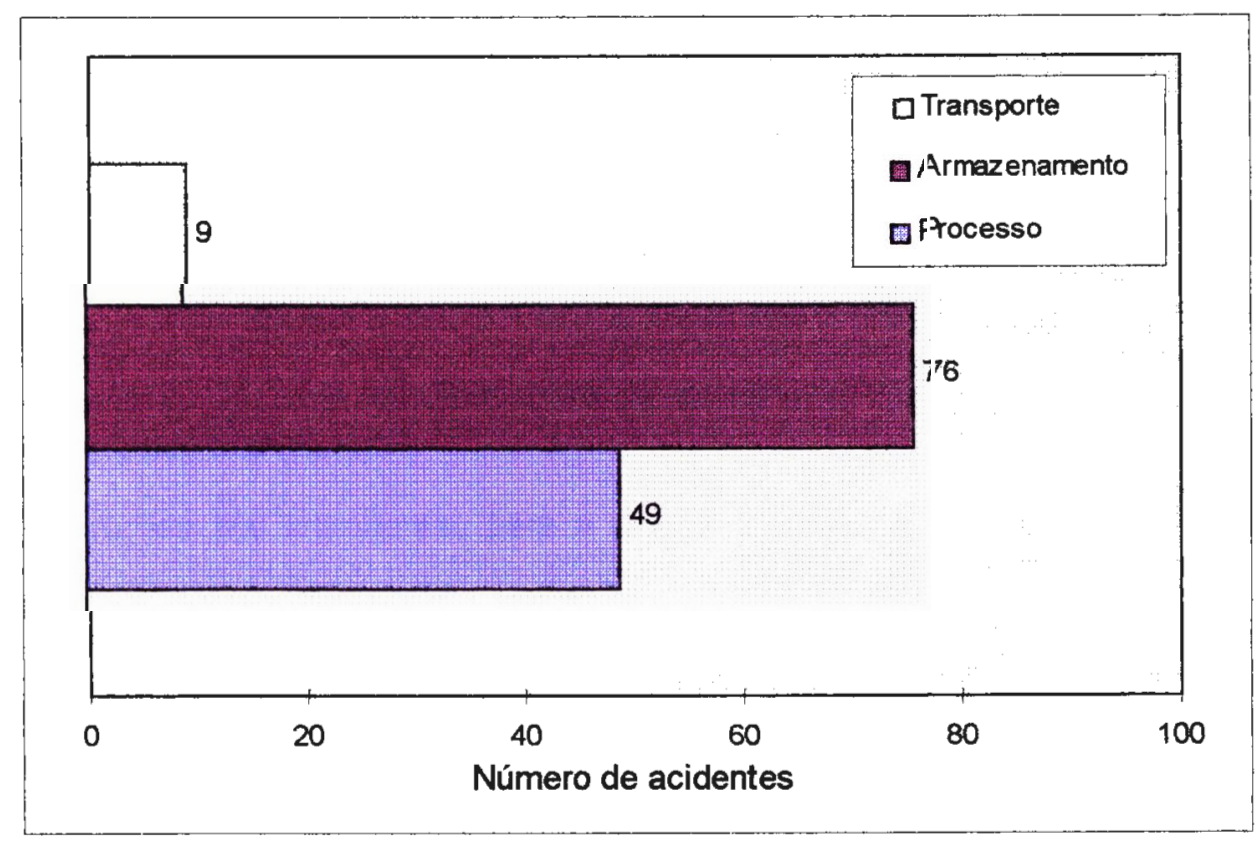


Figura 7. Freqüência com que os diferentes meios foram atingidos, nos acidentes registrados no CADAC, entre 1983 e 1997

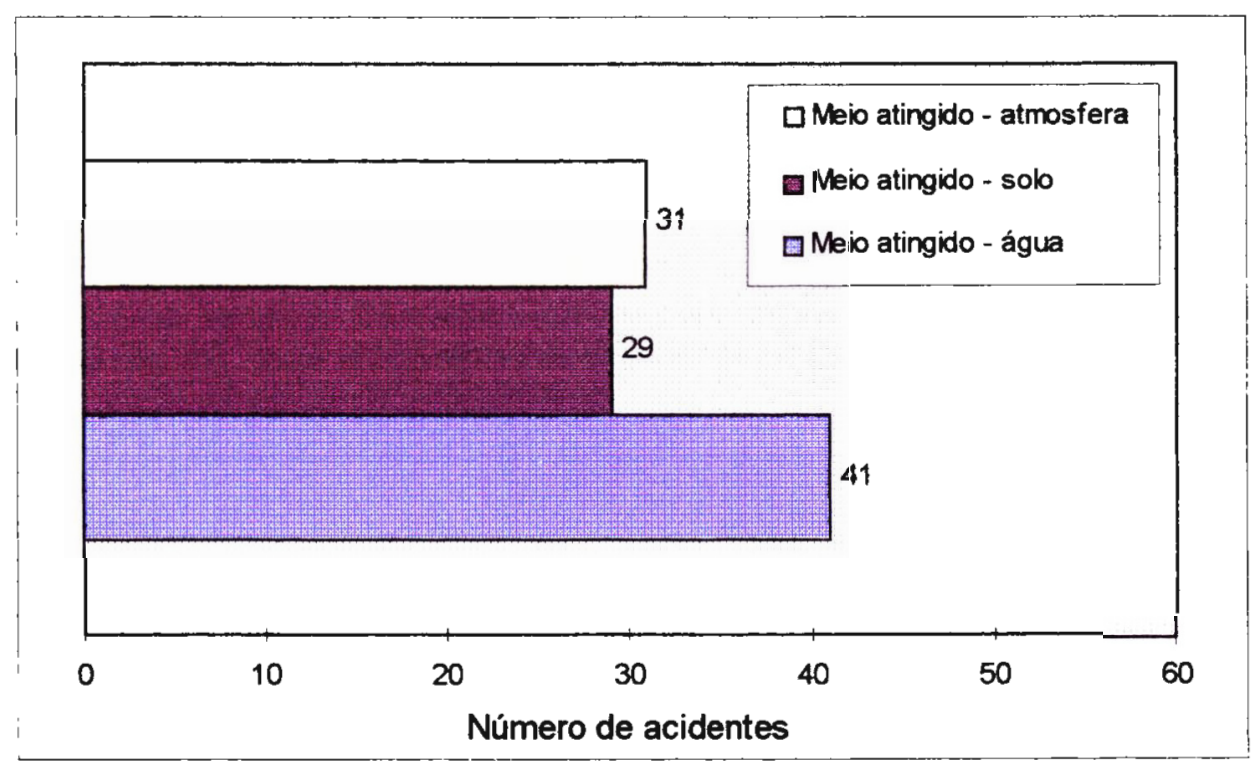

A CETESB mantém um cadastro especifico sobre acidentes ocorridos com o transporte rodoferroviário de produtos químicos e que não foi incluído neste trabalho.

Como análise final destes dados, pode-se considerar que os acidentes/incidentes registrados ocorreram principalmente durante o armazenamento de substâncias, com predominância dos casos de vazamentos de solventes, óleos combustíveis e ácidos inorgânicos que atingem os recursos hidricos ou redes de drenagem hídrica.

Estes resultados evidentemente corroboram a premissa deste trabalho, que pressupōe serem os acidentes maiores causas fundamentais de danos ao meio ambiente e à saúde humana, e que os vazamentos ou derrames contribuem significativamente para o incremento desses eventos.

Alguns dos casos registrados como vazamento efetivamente ficaram restritos à área da própria indústria, o que se explica pelo volume derramado ou por haver algum tipo de contenção ou ação corretiva imediata. Entretanto, vários casos ocorreram com conseqüências catastróficas (morte de animais) ou que poderiam ter sido mais danosos do que foram.

Os derrames de óleo ou outras substâncias líquidas ocorridas diretamente sobre o solo têm efeitos imediatos e a longo prazo, sendo o segundo meio mais afetado por um derrame de produtos. Embora os efeitos de um derrame sobre o solo nem sempre possam ser quantificados de imediato, a possibilidade de se atingir águas subterrâneas é relevante e deve ser considerada.

As emissões de gases ou vapores provocaram, conforme pode ser observado no CADAC, danos à saúde, ocasionando fatalidades.

Essas considerações são importantes para o direcionamento da definição de uma técnica de análise de risco que tenha como objetivo identificar, quantificar, classificar e mitigar os danos ao meio ambiente e à saúde humana.

Os dados internacionais obtidos através do banco de dados denominado SONATA (SERPA, com. pessoal) foram selecionados para conter somente acidentes ocorridos em indústrias siderúrgicas. Os dados abrangem o período de 1956 a 1987. Na tabela 9 são apresentados os dados registrados nesse período, e evidencia-se as substâncias presentes, o processo (sistema), o tipo de acidente e, finalmente, a quantidade de mortos/feridos nos acidentes relatados. Observa-se que nos registros não há menção a possiveis danos ao meio ambiente. Esse fato dificulta a 
complementação da avaliação das consequências dos eventos, por não permitir entender os controles existentes nas empresas sujeitas aos eventos indesejáveis.

Nessa mesma tabela 9 , pode-se verificar o registro de 29 acidentes fatais e 19 acidentes que provocaram lesões às pessoas. A figura 8 representa a ocorrência de acidentes envolvendo diferentes substâncias e produtos presentes no processo siderúrgico, notando-se a predominância (9) de substâncias denominadas carboquímicos (derivados do carvão), por serem geradas na coqueificação e recuperadas na forma de produtos químicos comercializados - benzeno, naftaleno, antraceno, tolueno, etc.. Os gases de coqueria constituem a segunda causa de acidentes, registrando 7 eventos.

\section{Figura 8. Ocorrência de acidentes envolvendo diferentes substâncias em usinas siderúrgicas, segundo o banco de dados SONATA (SERPA, com. pessoal, 1997)}

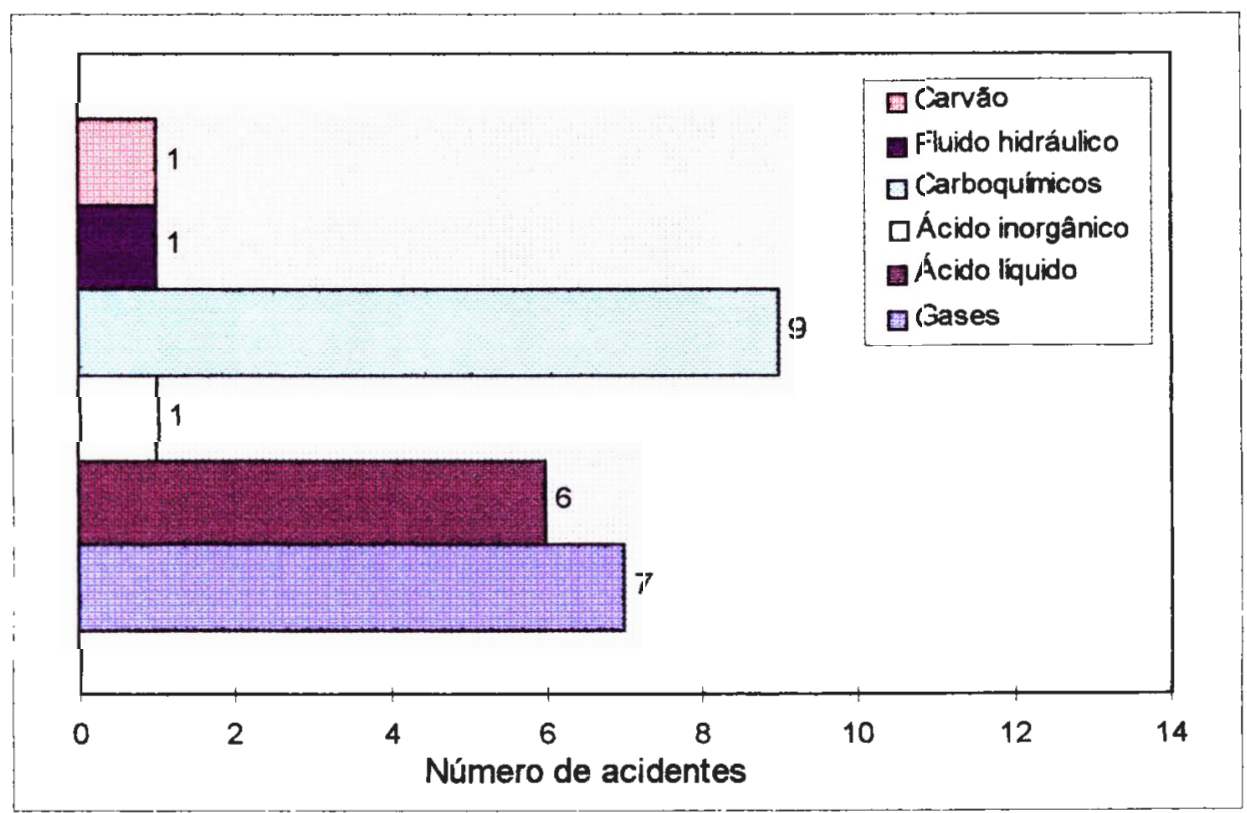

Entre as unidades ou sistemas geradores de acidentes, o sistema carboquímicos foi o que produziu maior número de acidentes (8) durante o periodo considerado (Fig. 9), representando $32 \%$ do total de acidentes. A coqueria e a aciaria tiveram registro de 6 e 5 acidentes, respectivamente. Conforme esperado, e em conformidade com o CADAC, os vazamentos (12) foram o tipo de evento que mais ocorreu, representando $48 \%$ dos eventos registrados. Incêndio e explosão tiveram 6 e 7 casos registrados (Fig. 10).

A análise dos registros do banco de dados SONATA para as atividades industriais siderúrgicas revela, resumidamente, que os acidentes/ incidentes cadastrados ocorreram predominantemente no sistema carboquímicos ( $32 \%$ dos casos), com efetivação de vazamentos (gases e líquidos) (48\% dos casos), envolvendo produtos denominados genericamente carboquímicos $(36 \%$ dos casos), por serem processados nesse sistema.

\subsubsection{Controles existentes}

As considerações feitas até agora têm mostrado que a ocorrência de acidentes com conseqüências ambientais é possível e implica em sérios danos. Evidentemente, os danos não são somente ambientais, e dai a grande preocupação dos gerenciadores dos processos que apresentam algum risco identificado.

O problema existente em países não industrializados ou em desenvolvimento é exatamente o desconhecimento dos riscos presentes. Esse desconhecimento ocorre devido à falta de informações técnicas, transferência de tecnologia, concorrência interna/externa, baixos investimentos em treinamento e desinteresse dos administradores. Essa afirmação pode ser 
confirmada pelo fato de algumas empresas estarem pagando altos prêmios a seguradoras, quando poderiam reduzir significativamente esses custos através da identificação e controle desses riscos.

Figura 9. Ocorréncia de acidentes nas diversas unidades ou sistemas em usinas siderúrgicas, segundo o banco de dados SONATA (seg. SERPA, com. pessoal, 1997)

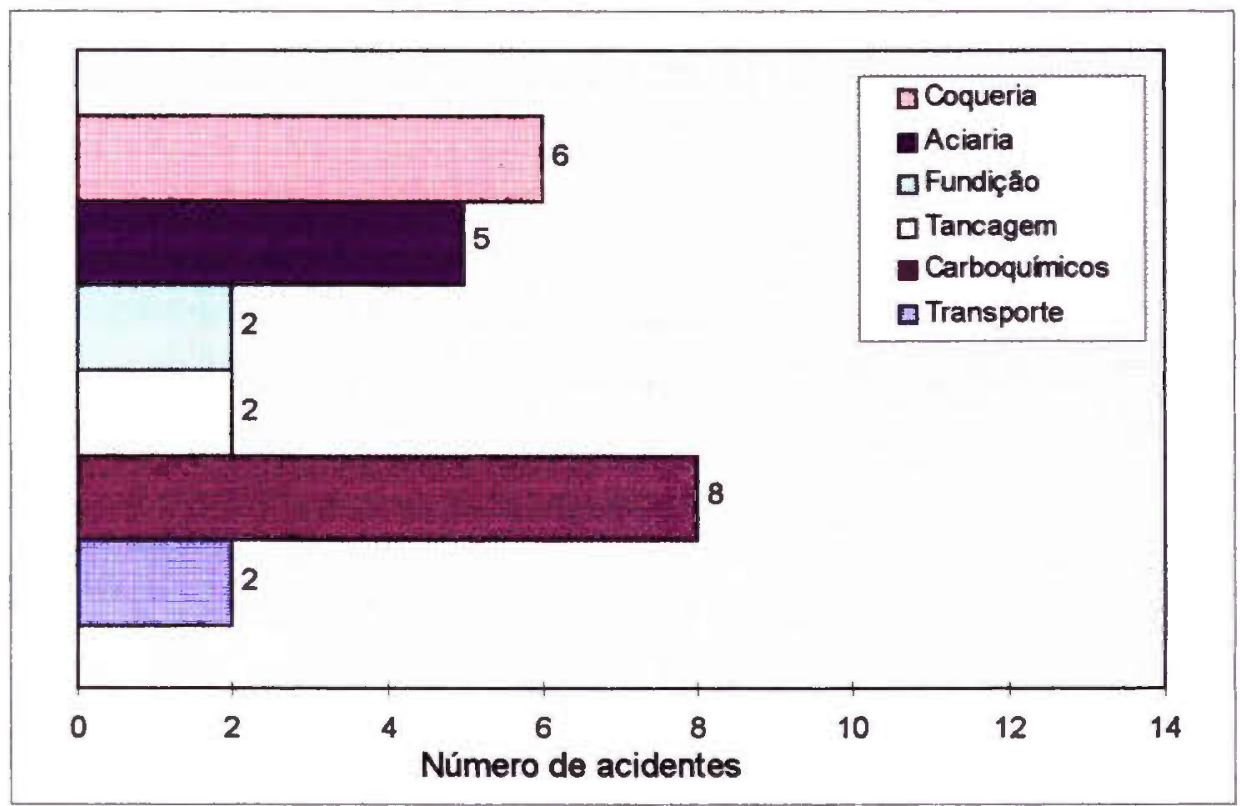

Figura 10. Quantidade de acidentes envolvendo incéndio, explosão e vazamentos, em indústrias siderúrgicas, segundo o banco de dados SONATA (seg. SERPA, com. pessoal, 1997)

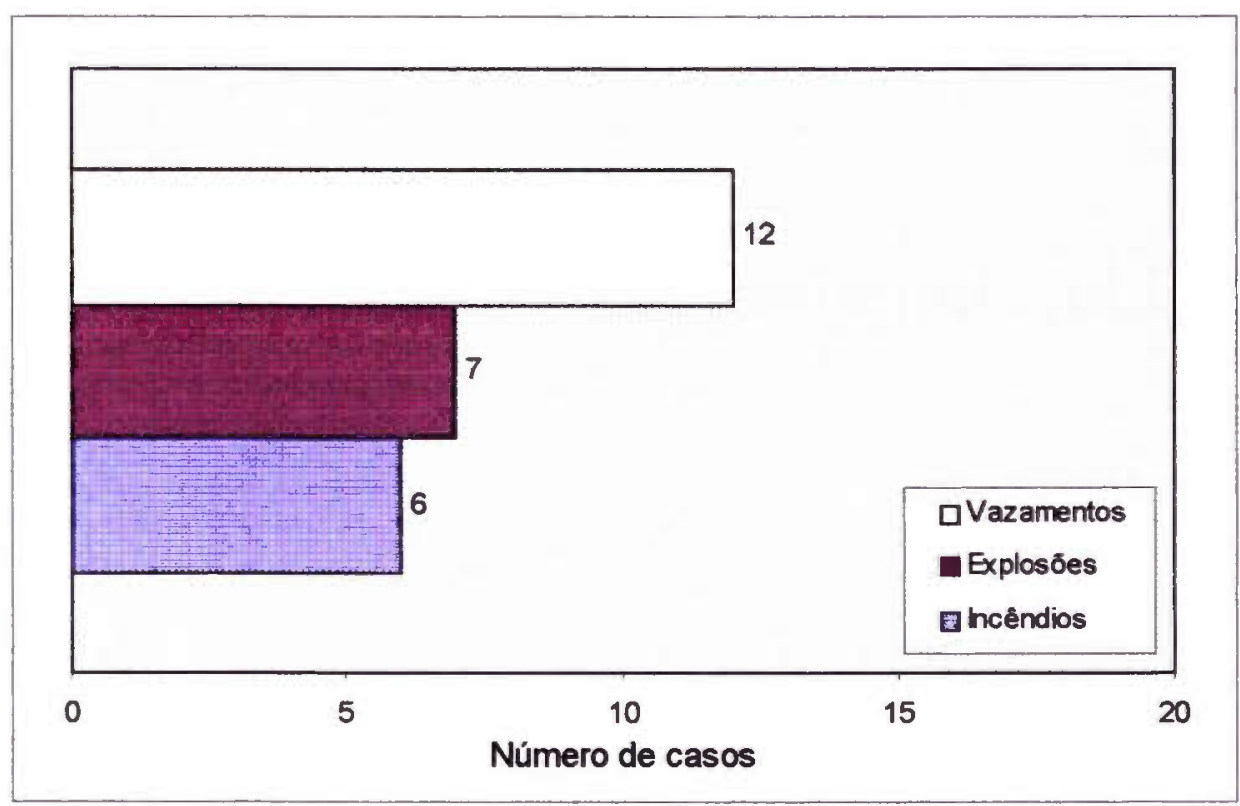

Os controles que devem ser propostos variam de acordo com o risco presente e também com a magnitude desses riscos. Além disso, existem os controles conhecidos como preventivos e 
aqueles corretivos, e os que implicam na colocação de equipamentos ou instrumentos ou somente treinamento e manutenção.

De qualquer maneira, essa especialidade de engenharia está muito bem desenvolvida, restando somente a decisão administrativa de implantar as recomendações dos técnicos envolvidos no projeto ou na operação do processo.

A melhor maneira de definir o controle necessário para um processo é a avaliação dos riscos que poderá apresentar quando instalado e operando. Para tanto, o uso de técnicas de análise de risco de processo, implementadas pelas técnicas que identificam ou quantificam os riscos ao meio ambiente, é recomendável, senão mandatário.

Além disso, não cabe neste trabalho enumerar o sem número de técnicas, processos e procedimentos que são aplicáveis na prevenção e controle de acidentes ambientais, mesmo reconhecendo que a maioria dos acidentes/incidentes com conseqüências ambientais envolve o vazamento ou derrame de produtos químicos perigosos. 


\subsection{PRINCIPAIS TÉCNICAS DE ANÁLISE DE RISCO DISPONIVEIS PARA INCORPORAÇÃO À ANÁLISE DE RISCO AMBIENTAL}

A aplicação da avaliação ou análise de risco é uma prática já antiga, iniciada em 1938 com a introduçăo da FDA através do Federal Food, Drug and Cosmetic Act. Durante as décadas de 40 e 50 , foi muito aplicada na indústria nuclear. A análise de risco de segurança é uma ferramenta poderosa, aplicada a partir dos anos 50 nos processos nucleares, químicos, petroquímicos e na indústria de aviação. As avaliaçðes de riscos à saúde foram introduzidas em 1976 com a publicação das "Carcinogenic Risk Assessment Guidelines”, pela USEPA.

A análise de risco ambiental ainda não está bem definida, carecendo de técnicas e estudos mais aprofundados, bem como uma clara definição de sua extensão e interação com as outras técnicas de análise de risco. Porém, vários estudos e propostas vêm sendo realizados (Tab. 10) para aprimorar as técnicas existentes visando sua aplicação de forma mais ampla, auxiliando os técnicos responsáveis pela sua elaboração e dando ao empreendedor uma visão abrangente dos problemas e soluções possiveis.

No histórico apresentado na tabela 10 , somente três tipos de riscos são identificados claramente: segurança, saúde e meio ambiente. Evidentemente, outros riscos estarão associados a estes já identificados, tais como o bem estar público e o financeiro (Tab. 11). $O$ bem estar público envolve - conceito de restrição de uso da propriedade, como odores indesejáveis, estéticos, comprometimento de visibilidade, e perda do valor patrimonial. Já o financeiro considera os custos de seguros, responsabilidade (interesses difusos) e direito de ações por danos anteriores.

A análise de risco de segurança, conforme a tabela 11, é determinada pela fatalidade, danos e perdas econômicas. $O$ efeito da realização do evento é imediato e geralmente transparente. A análise de risco de segurança é probabilística e incorpora a probabilidade de eventos iniciais, de exposição e uma estimativa de conseqüência da realização do evento analisado. $O$ mesmo não ocorre com a análise de riscos à saúde. O número de causas que levam ao risco, os efeitos sinergísticos e antagônicos dos agentes, a exposição continuada ou não, ocorrência de efeitos semelhantes em populaçōes não expostas aos mesmos agentes, levam à incerteza quanto à interpretação de causa-efeito de um evento estudado ou analisado.

A análise de risco ambiental (ARA) envolve conceitos e técnicas de avaliação ainda mais complexos e dificeis de serem obtidos. Os efeitos sobre um ecossistema podem ser agudos, ocorrendo a morte de um determinado componente quando do evento indesejado. Sua extensão e intensidade, porém, poderão não atingir níveis que possam comprometer o ecossistema local. Além desse fato, há ainda, especialmente para as condições nacionais, o pouco conhecimento da composição e comportamento da fauna e flora típicas das regiões mais urbanizadas, contribuindo para dificultar a elaboração da ARA.

Tanto a análise de riscos à saúde quanto a ARA são avaliações lógicas porém tipicamente determinísticas e usam estimativas menos sofisticadas que a análise de risco de segurança, que são mais elaboradas e enfáticas.

$\mathrm{Na}$ avaliação dos riscos envolvidos num projeto ou numa unidade em operação são feitas várias perguntas que permitem conhecer a natureza de um perigo existente, a possibilidade de sua ocorrência, o potencial de exposição ao evento, as características das comunidades que podem ser afetadas (fauna, flora e humana), a probabilidade de ocorrer o evento, a área de influência do evento e as suas conseqüências. As perguntas clássicas do tipo: o que pode dar errado e por quê? quão ruim pode ser seu efeito? qual a sua probabilidade? e 0 que pode ser feito para conhecer e evitar esse risco? levam a encarar o risco de um evento indesejável como uma função do conhecimento, ou não, de todas as variáveis propostas anteriormente e de identificar meios de quantificá-las e qualificá-las para em seguida propor a eliminação dos riscos.

Baseados em estudo feito pela USEPA - United States Environmental Protection Agency, intitulado "Reducing Risk: Setting Priorities and Strategies for Environmental Protection", 1990, 
Tabela 10. Surgimento da avaliaçăo quantitativa de risco: marcos selecionados - EUA (segundo KOLLURU, 1996)

\begin{tabular}{|c|c|}
\hline Ano & Eventos \\
\hline 1938 & Federal Food, Drug, and Cosmetic Act \\
\hline $1940 s-50 s$ & $\begin{array}{l}\text { Desenvolvimento e aplicaçăo de técnicas probabilisticas a operaçbes em energia atómica e aercespaciais } \\
\text { (técnicas e procedimentos HAZOP, modo de falhas, árvore de falhas) }\end{array}$ \\
\hline 1958 & Emendas ao Federal Food, Drug, and Cosmetic Act - Cláusula Delaney \\
\hline 1975 & Estudo da seguranca do Reator WASH-1400 (Rasmussen). U.S. Nuclear Regulatory Commission \\
\hline 1976 & $\begin{array}{l}\text { Publicaçbes da EPA com diretrizes para avaliaçăo do risco de carcinogénese (primeira Quantificaçăo dos } \\
\text { riscos químicos de câncer em seguida aos riscos de cáncer por radiaçåo }\end{array}$ \\
\hline $1900 \mathrm{~s}$ & $\begin{array}{l}\text { Enfase renovada na proteça da saúde humana, especialmente quanto aos riscos de cáncer, por exemplo, } \\
\text { critérios de qualidade de água baseados no risco } 10^{7} \text { a } 10^{-5} \text { modelo dose-resposta linearizado multiestágio }\end{array}$ \\
\hline 1980 & $\begin{array}{l}\text { Regra da Suprema Corte, determinando que OSHA deveria demonstrar ser benéfico na reduçáo do limite de } \\
\text { benzeno, de } 10 \mathrm{ppm}\end{array}$ \\
\hline 1981 & Primeira publicacăo do jornal Risk Analysis, da Society for Risk Analysis \\
\hline 1983 & Relatório da NAS/NRC Risk Assessment in the Federal Govermment: Managing the Process \\
\hline 1986 & $\begin{array}{l}\text { Formalizaçắo das diretrizes sobre avaliaçăo de risco } \\
\text { Superfund Public Health Evaluation Manual (SPHEM) } \\
\text { Exposure and Risk Assessment Guidelines, de } 1986 \text { (incluindo mutagênese, carcinogênese, riscos de } \\
\text { desenvolvimento, causados por misturas químicas) } \\
\text { Importância do apoio das comunicaçes de risco no gerenciamento de risco (SARA Titte III, 1986) }\end{array}$ \\
\hline 1987 & Publicecăo da EPA Unfinished Business: A Comperative Assessment of Environmental Problems \\
\hline 1969 & $\begin{array}{l}\text { Publicaçoes da EPA: Risk Assessment Guidance for Supertund (RAGS), Human Heath Evaluation } \\
\text { Manual; Environmental Evaluation Manual }\end{array}$ \\
\hline 1990 & $\begin{array}{l}\text { Publicaça do EPA Science Advisory Board: Reducing Risk: Selting Prionities and Strategies for } \\
\text { Environmental Protection } \\
\text { Programas de Gerenciamento de Riscos da EPA, sob as emendas do Clean Air Act de } 1990 \text { (tóxicos no ar, } \\
\text { prevencăa de emissóes acidentais) }\end{array}$ \\
\hline $1990 s$ & 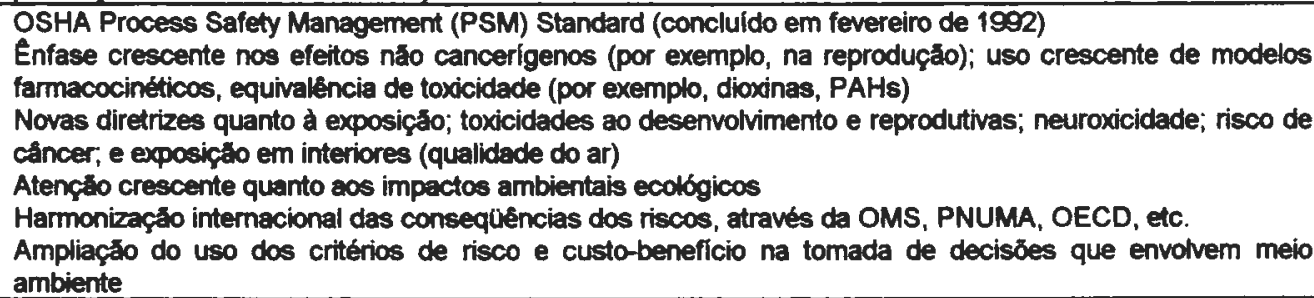 \\
\hline
\end{tabular}

Tabela 11. Principais tipos de riscos

\begin{tabular}{l|l|l|l|l|l}
\hline $\begin{array}{c}\text { Risco } \\
\text { Identificado }\end{array}$ & Probabilidade & Consequénclas & Efelto & Reeposta & Comprometimento \\
\hline Segurança & baixa & altas & $\begin{array}{l}\text { Imediato } \\
\text { Agudo }\end{array}$ & crítica & $\begin{array}{l}\text { Segurança humana e } \\
\text { prevençáo de perdas }\end{array}$ \\
\hline Saúde & alta & baixas & Demorado & crónico & Saúde humana \\
\hline Ambiental & $\begin{array}{l}\text { mudanças } \\
\text { sutis }\end{array}$ & $\begin{array}{l}\text { interaçóes } \\
\text { complexas }\end{array}$ & Incerto & $\begin{array}{l}\text { longa } \\
\text { laténcia }\end{array}$ & Ecossistema \\
\hline $\begin{array}{l}\text { Bem estar } \\
\text { público }\end{array}$ & percepçáo & $\begin{array}{l}\text { valor da } \\
\text { propriedade }\end{array}$ & Estético & negativa & Valores \\
\hline Financeiro & $\begin{array}{l}\text { viabilidade de } \\
\text { negócios }\end{array}$ & responsabilidades & Insegurança & negativa & Económico \\
\hline
\end{tabular}

"o conceito de risco ambiental, juntamente com sua terminologia e metodologia, ajuda o público a entender e discutir os problemas ambientais. O conhecimento de risco ambiental auxilia também na avaliaçāo e mediçäo do problema e na sua comparaçäo com termos comuns, permitindo ainda diferentes opiniōes sobre a reduçāo do risco desejada" (KOLLURU, 1996). Esse conceito foi obtido considerando, evidentemente, a necessidade de haver leis, políticas, programas e as ferramentas básicas para conhecer, avaliar e propor medidas claras e compatíveis com a realidade econômica e ambiental de uma dada região. Entre as dez diretrizes básicas contidas 
nesse trabalho, três fazem menção clara à necessidade de desenvolvimento e aplicação de metodologia apropriada, confiável e reprodutível.

Um dos objetivos do presente trabalho é definir uma ou mais técnicas de análise de risco ambiental, que possam ser quantitativas, com bases reais e confiáveis, além de serem úteis para permitir o gerenciamento dos aspectos de segurança de um processo e fomentar procedimentos e políticas de prevenção de perdas, comunicação e gerenciamento de riscos e de impactos ambientais.

De uma maneira geral, uma análise de risco, do tipo clássico e que envolve o risco à segurança, pode ser expressa na forma de um diagrama de blocos, conforme a figura 11.

Os passos que compõem a análise de risco consistirá, portanto, dos seguintes passos:

- definição do escopo da análise de risco

- obtenção do histórico dos acidentes ocorridos em processo semelhante

- uso de técnica de análise de risco

- verificar se o risco é tolerável

- se necessário, corrigir ou mitigar os riscos

- recalcular os riscos e rever a sua tolerabilidade

- implantação e gerenciamento dos riscos identificados

Os passos propostos para elaboração da análise de risco podem ser simplificados em três etapas essenciais:

- identificação do grau de risco do processo

- definição das hipóteses de acidentes/estimativa da probabilidade

- avaliação das conseqüências de acidentes definidas

A análise dos riscos presentes em um processo visa atingir as metas de proteção de um sistema através da identificação sistemática do risco existente, fornecendo uma análise qualitativa (na maioria das vezes) e apresentando seu significado em termos de probabilidade de ocorrência de um evento crítico e a conseqüência, ou impacto ao meio ambiente, do efeito do evento crítico.

Embora as ARA tendam a ser deterministicas, o emprego de técnicas consagradas na análise de riscos à segurança pode levar à aplicação com resultados probabilísticos, tornando-se mais confiáveis e realisticos.

Várias são as técnicas usadas e recomendadas para uma análise de risco que envolva segurança, saúde e meio ambiente. A maioria delas são adotadas por organismos internacionais tais como EPA, OSHA, PSM e Responsible Care Program, entre outros (STRICOFF, 1996, apud KOLLURU, 1996).

A figura 12 representa uma redução do fluxograma já apresentado anteriormente (Figura 11) para a realização de uma análise de risco. Nesta figura, são apresentadas, no entanto, as técnicas mais amplamente aceitas para atender as necessidades das indústrias, dos órgãos de controle ambiental e de segurança e as necessidades de proteção ao meio ambiente. Além das técnicas mais recomendadas, e que serão discutidas a seguir, a figura 12 apresenta ainda os dados mínimos necessários para a elaboração de cada um dos processos previstos na execução da análise de risco.

Muitas outras técnicas poderiam ser citadas, porém a sua eficácia na avaliação de riscos, probabilidade de ocorrência de um evento e os impactos ambientais observados têm sofrido críticas. Além disso, as técnicas tornaram-se clássicas e de conhecimento amplo, possibilitando a sua aplicação por diferentes profissionais de diferentes áreas técnicas. Outros fatores, como: complexidade de obtenção de dados, não conformidade de resultados práticos com aqueles propostos, dificuldade de reprodução dos resultados quando aplicadas a processos idênticos, porém com alguma variável em destaque, técnicas puramente acadêmicas, levaram este trabalho a relacionar e discutir as técnicas selecionadas e mais amplamente difundidas e aceitas. 
Figura 11. Diagrama de bloco para realização de uma análise de risco

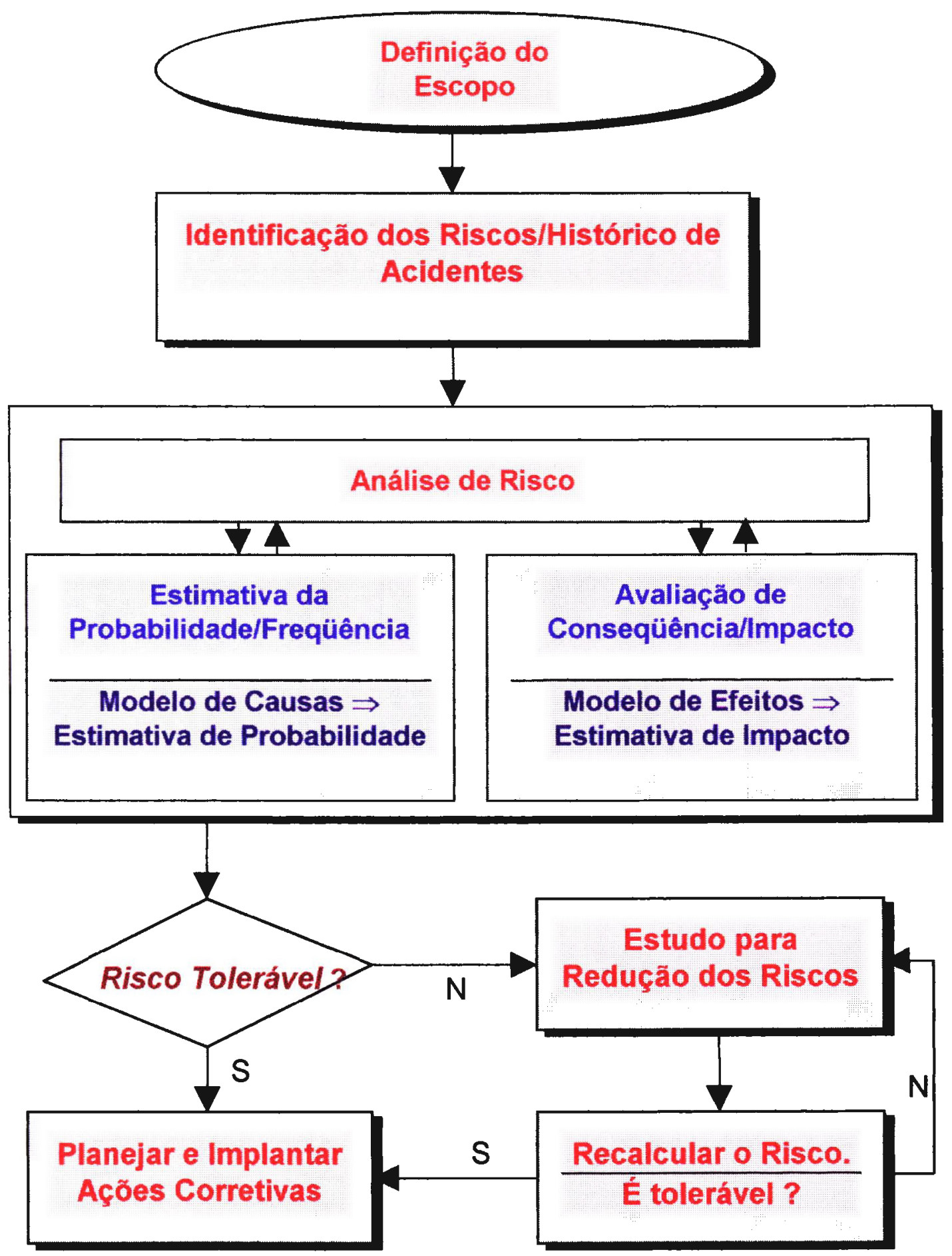


Figura 12. Fluxograma simplificado para realizaçăo de uma análise de risco

\begin{tabular}{|c|c|c|c|c|}
\hline Processos & \multirow{2}{*}{$\begin{array}{ll} & \text { Técnicas de análise } \\
\text { - } & \text { CATBRAS } \\
\text { - } & \text { Dow } \& \text { Moud } \\
\text { - } & \text { Sevid ranking } \\
\text { - } & \text { Seso/Banco Mundial } \\
\end{array}$} & \multirow{2}{*}{ Dados necessários } & \multicolumn{2}{|c|}{ Interacoes } \\
\hline $\begin{array}{l}\text { Identificaçăo preliminar dos riscos } \\
\text { das unidades }\end{array}$ & & & $\begin{array}{l}\text { pessoas e } \\
\text { propriedades } \\
\text { meio ambiente }\end{array}$ & $\begin{array}{l}\text { empregados } \\
\text { - órgáo de } \\
\text { controle }\end{array}$ \\
\hline $\begin{array}{l}\text { Identificaçăo dos cenários de } \\
\text { falhas }\end{array}$ & $\begin{array}{l}\text { - What-if } \\
\text { - Check list } \\
\text { - APR }\end{array}$ & $\begin{array}{l}\text { - descriçăo do processo } \\
\text { - } \text { registro de acidentes (histórico) } \\
\text { - } \text { normas e leis ambientais } \\
\text { - } \text { ambientais da regiăo } \\
\text { - toxicológicos }\end{array}$ & $\begin{array}{ll}\text { - } & \text { pessoas e } \\
\text { propriedades } \\
\text { - } \\
\text { - }\end{array}$ & $\begin{array}{l}\text { - empregados } \\
\text { - órgåo de } \\
\text { controle }\end{array}$ \\
\hline Estimativa de consequéncias & $\begin{array}{l}\text { - observaçăo direta } \\
\text { - julgamento de engenharia } \\
\text { - } \quad \text { cécnica simples de } \\
\text { conseqǘśncia (qualitativa) }\end{array}$ & $\begin{array}{l}\text { - relaça de equipamentos que possam gerar incêndio, } \\
\text { explosto ou vazamento }\end{array}$ & $\begin{array}{ll}\text { - } & \text { pessoas e } \\
& \text { propriedades } \\
\text { - } & \text { meio ambiente } \\
\text { - } & \text { proprietários/sócios }\end{array}$ & $\begin{array}{l}\text { empregados } \\
\text { - órgăo de } \\
\text { controle }\end{array}$ \\
\hline Conseqüếncias săo toleráveis & $\begin{array}{l}\text { - julgamento técnicol } \\
\text { administrativo }\end{array}$ & $\begin{array}{l}\text { - legistaçăa } \\
\text { - dados ambientais } \\
\text { - custos }\end{array}$ & $\begin{array}{ll}\text { - } & \text { seguradoras } \\
\text { - } & \text { emprietários/sócios } \\
\text { - empodos }\end{array}$ & $\begin{array}{l}\text { - órgåo de } \\
\text { controle } \\
\text { comunidades }\end{array}$ \\
\hline Análise qualitativa dos riscos & $\begin{array}{ll}- & \text { HAZOP } \\
- & \text { AMFE } \\
- & \text { AAE } \\
\end{array}$ & $\begin{array}{l}\text { - registro de acidentes } \\
\text { - diagrama esquemático dos equipamentos } \\
\text { - procedimentos operacionais }\end{array}$ & $\begin{array}{l}\text { responsáveis pelos } \\
\text { processos }\end{array}$ & \\
\hline Análise quantitativa dos riscos & $\begin{array}{ll}- & \text { AAF } \\
- & \text { ACN } \\
\text { EP/F }\end{array}$ & $\begin{array}{l}\text { - os acima, mais: } \\
\text { - taxa de falha de equipamento } \\
\text { - taxa de falhas humanas }\end{array}$ & - idem acima & \\
\hline Os riscos sảo toleráveis? & $\begin{array}{l}\text { - critérios técnicos } \\
\text { - legislaçăa } \\
\text { - impactos }\end{array}$ & $\begin{array}{l}\text { - legislaçáo } \\
\text { - ambientais/sociais } \\
\text { - experiéncia anterior } \\
\text { - custos } \\
\end{array}$ & $\begin{array}{l}\text { - ógăo de controle } \\
\text { - proprietários } \\
\text { - comunidades } \\
\end{array}$ & $\begin{array}{l}\text { - } \text { seguradoras } \\
\text { - } \\
\text { - }\end{array}$ \\
\hline $\begin{array}{l}\text { Reduçato de custos e alternativas } \\
\text { de controle }\end{array}$ & - análise custo/beneficio & - custos & $\begin{array}{l}\text { proprietários } \\
\text { - engenharia }\end{array}$ & $\begin{array}{l}\text { - orgåo de } \\
\text { controle }\end{array}$ \\
\hline $\begin{array}{l}\text { Săo os custos e riscos } \\
\text { aceitáveis? }\end{array}$ & - idem acima & - custos/novas técnicas & - proprietários & $\begin{array}{l}\text { - órgâo de } \\
\text { controle }\end{array}$ \\
\hline $\begin{array}{l}\text { Estratégia para gerenciamento } \\
\text { dos riscos }\end{array}$ & Produtos , & $\begin{array}{l}\text { - reduçắo do risco ao meio ambiente } \\
\text { - seguros e retençăo de riscos } \\
\text { - análises custobeneficios }\end{array}$ & $\begin{array}{l}\text { - medidas preventivas } / c 0 \\
\text { - reduçăo do risco de aci } \\
\text { empregados }\end{array}$ & Tetivas \\
\hline
\end{tabular}


A seguir, são apresentadas as técnicas típicas de análise de risco de segurança que serão consideradas neste trabalho, visando sua adaptação e uso para avaliar a probabilidade de ocorrência de um acidente com conseqüências ambientais. Essas técnicas estão publicadas internacional e nacionalmente. Dessa forma, o presente trabalho optou pela inclusão dessas descrições já feitas e publicadas, bem como de suas versões nacionais. As principais referências das quais foram compiladas essas descrições são: FANTAZZINI \& DE CICCO (1985), DE CICCO \& FANTAZZINI (1985), KAYES (1985), CETESB (1988), ITSEMAP (1992), MAKARON (1992).

Como dito anteriormente, as técnicas de análise de risco podem ser colocadas em três grupos:

1. priorização rápida ou identificação do grau de risco do empreendimento;

2. definição das hipóteses de acidentes ou análises qualitativas, que podem ainda ser desmembradas em dois grupos menores:

a. técnicas simples de identificaçăo de riscos;

b. analises de risco qualitativas propriamente ditas, que visam identificar as hipóteses de acidentes;

3. estimativa de probabilidade/avaliação das conseqüências das hipóteses de acidentes ou análises de risco quantitativas, que são aplicadas na análise dos riscos identificados.

\subsubsection{Priorização rápida ou identificação do grau de risco}

Vários acidentes classificados como catastróficos (perda de vidas, propriedades e danos ambientais severos) que ocorreram no passado recente das atividades industriais levaram os administradores a procurar técnicas que pudessem informá-los dos riscos que suas atividades apresentavam. Foram apresentados alguns critérios, que são utilizados atualmente, para obter uma classificaçăo baseada no conceito de "risco de acidente catastrófico" ou "risco de acidente maior". Essas classificações permitem ao gerenciador identificar as instalações ou atividades que apresentam risco maior à segurança, patrimônio, saúde e meio ambiente. Esses riscos envolvem incêndio, explosăo ou liberação de substâncias tóxicas (vazamento).

As técnicas que permitem uma priorização rápida de atuação para prevenção da ocorrência de acidentes maiores estão na tabela 12, que relaciona também os princípios de cada uma delas.

\subsubsection{Definição das hipóteses de acidentes ou análises de risco qualitativas}

As análises de risco qualitativas envolvem técnicas que privilegiam o conhecimento anterior do processo sob análise e em especial a capacidade dos técnicos que a estão elaborando, em identificar ou obter dos operadores do sistema/equipamento, possiveis potenciais de acidentes.

Trata-se de evidenciar situações que possam levar à ocorrência de um evento indesejado ou hipótese de acidente, através da análise de um projeto, ou de um desenho de um determinado sistema, considerando informações anteriores, tais como o histórico de acidentes de um sistema, registro de acidentes com trabalhadores, falhas e observações durante a realização de manutenção e do treinamento de pessoal.

Cada técnica evidentemente tem a sua peculiaridade e aplicação prática. No entanto, elas se baseiam nas informações citadas e invariavelmente consideram a capacidade e a experiência do gerenciador do processo de análise. Essa experiência começa exatamente com a seleção da técnica mais indicada para o sistema analisado, os recursos humanos e profissionais disponiveis e as informaçōes de que vai dispor.

Essas técnicas podem ainda considerar sua facilidade de aplicação ou rapidez de atingir um objetivo. Nesse caso, há uma subdivisão lógica das técnicas classificadas como qualitativas: as técnicas simples de identificação de risco e as análises de risco qualitativas.

Algumas das técnicas consideradas como qualitativas poderão sob certas circunstâncias serem classificadas como quantitativas, já que podem permitir a junção de dados quantificados para efetuar previsões e estimativas de ocorrência de um determinado evento ou risco. 
As principais técnicas de análise de risco para identificação com características qualitativas estruturadas são:

- Técnicas simples de identificação de risco

- Análise Preliminar de Riscos - APR

- "What If "/ "Checklist "

- Identificação de Perigos e Estudo de Operabilidade - HAZOP

- Análise de Modos de Falhas e Efeitos - AMFE

- Análise de Árvore de Eventos - AAE

\subsubsection{Técnicas simples de identificação de risco}

As técnicas simples de identificação de risco, de aplicação rápida e de fácil entendimento pelos empregados e responsáveis por um setor, visam identificar a hipótese de riscos de uma operação ou procedimento que podem gerar situações de risco com danos à saúde do trabalhador, ao patrimônio da empresa e ao meio ambiente.

Normalmente, são aplicadas em estações de transbordo de produtos químicos, armazenamento e transporte de material perigoso, operações com sistemas de transferência de produtos químicos, etc. Algumas vezes podem ser incluídos itens como estrutura do prédio ou de máquinas, pressão, temperatura, níveis de produtos, uso de equipamentos de segurança, datas de validade, realização de manutenção preventiva, dados de monitoramento ambiental, etc.

As técnicas mais conhecidas são:

- incidentes críticos

- investigação de acidentes

- planilha de segurança

- inspeção ("check list")

Essas técnicas apresentam algumas vantagens e muitas limitações, como pode ser observado na tabela 13. Para o presente trabalho, o maior entrave na consideração das técnicas de identificação de riscos é sua quase nula aplicação em casos que possam envolver os riscos e os danos ambientais. Normalmente sua aplicação não considera o alcance de um acidente além daquele limitado ao posto de trabalho, ou a um equipamento em particular. E evidente que sua importância é revelada quando se propõe a auxiliar na obtenção de um processo adequado de manutenção de segurança preventiva ou preditiva.

\subsubsection{Análise Preliminar de Riscos - APR}

Objetivos - Determinação de riscos e medidas preventivas de qualquer novo processo, produto ou sistema.

Descrição geral - A Análise Preliminar de Riscos (APR) baseia-se na técnica definida e usada pelos militares nos programas de segurança de seus sistemas (DEPARTMENT OF DEFENSE, 1984). Muitas empresas químicas possuem um método semelhante implantado, talvez com nome diferente. Esta análise evidenciou-se altamente eficiente em relação ao custo, na fase de desenvolvimento de todos os sistemas militares perigosos, inclusive as unidades de processo. É também possivel usar a análise em questão para anteceder outros métodos mais detalhados de identificação de riscos a serem utilizados em outras oportunidades no decorrer da vida da fábrica.

A APR é efetuada mediante a listagem dos riscos associados aos elementos do sistema, como definido no estágio de concepção ou do começo do projeto. Os elementos da instalação, que podem ser definidos neste estágio, compreendem:

- matérias-primas, produtos intermediários e finais e sua reatividade;

- equipamentos de processo;

- interface entre componentes;

- ambiente operacional;

- operações (teste, manutenção, procedimentos de emergência, etc.); 


\section{Tabela 12. Principals técnicas de priorização rápida para acidentes maiores}

\begin{tabular}{|c|c|}
\hline Técnicas & Princlpio \\
\hline Análise histórica & Obtençăo de dados históricos de acidentes ocorridos em atividades semelhantes. Formaçăo de banco de dados sobre acidentes com danos significativos \\
\hline Diretiva de Seveso & $\begin{array}{l}\text { Análise do processo e armazenamento de substâncias perigosas e que apresentem potencial de explosăo, incéndio e liberaçăo de substâncias tóxicas. O método considera } \\
\text { um grau de risco em funçăo das propriedades físicas e quimicas das substâncias e a área exposta a um evento (homem, propriedades). }\end{array}$ \\
\hline Índices Dow \& Moud & $\begin{array}{l}\text { O Índice Dow classifica o processo quanto à possibilidade da ocorréncia de incidentes com explosăo e incéndio. Considera as propriedades física-químicas das } \\
\text { substâncias, condiçzes de armazenamento, acesso e sistema de drenagem e controle de vazamentos. Os casos de liberaçăo de substâncias tóxicas consideram a } \\
\text { toxicidade do produto, a pressăo atmosférica, local da operaçăo e proximidade de fontes de incéndio/explosăo e pressão de segurança, etc.. }\end{array}$ \\
\hline "Rapid Ranking" & $\begin{array}{l}\text { Trata-se de técnica desenvolvida pela ICI que considera: o custo das instalaçöes, probabilidade de incéndio e explosão, toxicidade de subståncias armazenadas e a } \\
\text { frequéncia tipica do evento em estudo. Na realidade, a análise fornece uma prioridade de açăo de controle ou estudo entre duas ou mais unidades (processos) em funçăo do } \\
\text { risco apresentado. }\end{array}$ \\
\hline "Hazard Study I" & $\begin{array}{l}\text { Técnica também desenvolvida pela } \mathrm{ICl} \text {, porém mais elaborada, baseada nas premissas de projetos de empreendimentos. Considera a possibilidade de incidentes com } \\
\text { liberaçăo de substâncias tóxicas, incêndio e explosăo a partir de dados físico-químicos e avalia possiveis riscos ambientais por não previsăo de sistemas de contençăo de } \\
\text { substâncias dentro da área do incidente. Năo apresenta prioridade de açăo e não considera a área de influência do processo (em caso de acidente maior). }\end{array}$ \\
\hline CATBRÁS & $\begin{array}{l}\text { Método desenvolvido pela CETESB - Companhia de Tecnologia de Saneamento Ambiental, para classificaçăo, análise, avaliaçăo e gerenciamento de risco de fontes } \\
\text { potencialmente geradoras de acidentes ambientais e para a populaçăo. O método aplica-se à classificaçăa de fábricas, processos de armazenamento de substâncias } \\
\text { tóxicas, inflamáveis e/ou explosivas em: } \\
\text { I - alto potencial de risco; ll - médio potencial de risco; III - baixo potencial de risco; IV - classe especial de risco } \\
\text { Na classificaçăo, além do tipo e quantidades das substâncias presentes e as condiçōes do seu processo ou armazenamento, consideram-se ainda os parâmetros de } \\
\text { avaliaçăo de sensibilidade da área circunvizinha. }\end{array}$ \\
\hline $\begin{array}{l}\text { Manual do Banco } \\
\text { Mundial }\end{array}$ & $\begin{array}{l}\text { Técnica proposta pelo Banco Mundial para identificar, analisar e controlar instalaçóes com riscos de acidentes maiores em países desenvolvidos. Desenvolvida nas diretivas } \\
\text { da OECD, é baseada no processo de produçăo, tipo e características físico-químicas e toxicológicas das substâncias produzidas ou armazenadas (KAYES, 1985). }\end{array}$ \\
\hline
\end{tabular}


Tabela 13 - Principais objetivos das técnicas simples de identificação de risco

\begin{tabular}{l|l|l|l}
\hline \multicolumn{1}{c|}{$\begin{array}{c}\text { Técnica de } \\
\text { identificação }\end{array}$} & \multicolumn{1}{|c|}{ Princípios } & \multicolumn{1}{c}{ Vantagens } \\
\hline Incidentes críticos & $\begin{array}{l}\text { Entrevista com pessoal do setor, } \\
\text { procurando evidenciar atos e condições } \\
\text { inseguras que tenha feito ou observado }\end{array}$ & $\begin{array}{l}\text { identifica atos e condições inseguras } \\
\text { que contribuem para a ocorrência de } \\
\text { acidentes }\end{array}$ & $\begin{array}{l}\text { própria para avaliação de acidentes e lesões em } \\
\text { operários; pouco útil para questões ambientais e } \\
\text { patrimoniais }\end{array}$ \\
\hline $\begin{array}{l}\text { Investigação de } \\
\text { acidentes }\end{array}$ & $\begin{array}{l}\text { Entrevista com um acidentado verificando } \\
\text { a sua atividade, seu comportamento, a } \\
\text { causa do acidente, etc. }\end{array}$ & $\begin{array}{l}\text { determinação da causa principal do } \\
\text { acidente e proposta de correção }\end{array}$ & pouco útil para questões ambientais \\
\hline $\begin{array}{l}\text { Planilha de } \\
\text { segurança }\end{array}$ & $\begin{array}{l}\text { Realização de inspeções de segurança } \\
\text { através de um formulário apropriado }\end{array}$ & $\begin{array}{l}\text { observação de pontos críticos e } \\
\text { elaboração de relatórios contendo os } \\
\text { pontos negativos }\end{array}$ & pouco útil para questões ambientais \\
\hline $\begin{array}{l}\text { Inspeção ("check } \\
\text { list") }\end{array}$ & $\begin{array}{l}\text { Avaliar, através de uma seqüência lógica } \\
\text { de perguntas e respostas, as condições de } \\
\text { segurança de um processo }\end{array}$ & $\begin{array}{l}\text { próprio para avaliar cumprimento de } \\
\text { normas e procedimentos, condições } \\
\text { de operação; conscientização }\end{array}$ & \begin{tabular}{l} 
pouco útil para questões ambientais; não \\
considera o alcance dos efeitos em caso de \\
\hline \hline
\end{tabular}
\end{tabular}


- instalações;

- equipamentos de segurança.

À medida que cada hipótese de risco é identificada, são também arroladas as causas em potencial, os efeitos e a gravidade dos acidentes, bem como as possíveis medidas corretivas e/ou preventivas. Para que o trabalho seja completo, é preciso aproveitar a experiência anterior, proveniente do maior número possível de fontes diferentes. Estas fontes compreendem estudos de risco de instalações semelhantes, experiência operacional em estabelecimentos análogos e listagens de riscos.

Diretrizes para a utilização do método - A APR compõe-se dos seguintes passos básicos:

1- reunir os dados necessários;

II- efetuar a análise preliminar de riscos;

III- registrar os resultados.

- reunir os dados necessários - A APR requer a reunião, antes de mais nada, dos dados disponiveis sobre a fábrica (ou sistema) em causa e, então, das informações pertinentes, proporcionadas pela experiência prévia com qualquer fábrica similar, ou mesmo com uma fábrica que trabalhe com processo diferente, mas utilize equipamentos e materiais semelhantes.

Como a APR destina-se especificamente à identificação antecipada das hipóteses de acidentes, os dados sobre o processo poderão ser escassos. No ponto de desenvolvimento do projeto em que a APR é útil, dentre os poucos dados disponiveis consta a concepção do processo. Assim, produtos químicos e reações básicas deverão ser conhecidos, bem como os principais tipos de equipamentos, notadamente itens de equipamentos especiais ou de longa vida, como, por exemplo, vasos, trocadores de calor e tipo de construção das instalações. Além dos componentes da fábrica, os objetivos operacionais desta e os requisitos básicos de desempenho são úteis à definição do contexto para os perigos e o ambiente no qual a fábrica irá operar.

É muito conveniente que se determine a disponibilidade de experiência prévia com as substâncias quimicas e/ou a concepção do processo em causa. Quaisquer problemas que venham a ser identificados graças à experiência prévia poderão auxiliar a APR da fábrica considerada.

II- efetuar a análise preliminar de riscos - O processo de execução da APR consiste em identificar os riscos, eventos iniciadores em potencial, e outros eventos capazes de gerar conseqüências indesejáveis. Os analistas devem igualmente identificar os critérios de projeto ou alternativas com possibilidades de eliminar ou reduzir os riscos considerados, capazes de determinar um nivel de riscos consideravelmente elevado. É evidente que é requerida uma certa experiência para efetuar tais avaliações. Na realização da APR, devem ser considerados os seguintes elementos:

a) equipamentos e materiais perigosos da fábrica, como, por exemplo, combustíveis, materiais químicos altamente reativos, substâncias tóxicas, sistemas de alta pressão e outros sistemas de armazenamento de energia;

b) interfaces entre equipamentos e materiais da fábrica associados à segurança, como, por exemplo, interações de materiais, inicio de propagação de incêndios ou explosões e sistemas de controle ou parada;

c) fatores ambientais suscetiveis de influenciar o equipamento e os materiais da fábrica como, por exemplo, terremotos, vibração, temperaturas extremas, descargas eletrostáticas e umidade;

d) procedimentos de operação, teste, manutenção e atendimento a situações de emergência, como, por exemplo, importância dos erros humanos, funções a serem desempenhadas pelos operadores, acessibilidade ou disposição do equipamento, e proteção contra acidentes com o pessoal;

e) elementos de apoio das instalações, como, por exemplo, armazenamento, equipamentos de teste, treinamento e utilidades;

f) equipamentos relacionados com a segurança, como, por exemplo, sistemas de atenuação, redundância, extintores de incêndio e equipamentos de proteção pessoal. 
III - registrar os resultados - Os resultados da APR são registrados convenientemente num formulário que mostra os riscos identificados, as causas, as conseqüências em potencial e quaisquer medidas identificáveis, corretivas ou preventivas. $O$ resultado é normalmente encaminhado ao gerente de projeto e ao pessoal de projeto da fábrica.

Tipo e natureza dos resultados - A APR é uma técnica qualitativa, năo voltada para um aprofundamento na determinaçăo dos riscos de um processo ou transporte e armazenamento de produtos, uma vez que existem técnicas de análise mais apuradas e adequadas para esse fim.

A APR é adequada para ser empregada na fase inicial de concepção e desenvolvimento das unidades de processo, na determinação dos riscos que possam existir. Ela năo exclui a necessidade de outros tipos de avaliaçáo de risco; ao contrário, é uma precursora de outras análises. Entretanto, a técnica apresenta uma série de vantagens, quando comparada com técnicas simples de análise de risco. As principais vantagens da APR são:

a) identificação antecipada dos riscos existentes no processo;

b) conscientização, por parte da equipe de projeto, dos perigos em potencial no empreendimento em estudo, ou em operação;

c) identificação e/ou desenvolvimento de diretrizes e critérios para a equipe de desenvolvimento do processo a seguir.

Assim, à medida que o projeto ou o estudo operacional se desenvolve, os perigos principais podem ser eliminados, minimizados ou controlados.

Considerando-se a variável ambiental, a APR pode ser usada para que seus benefícios sejam direcionados no sentido de proporcionar uma maior segurança ao meio ambiente e à comunidade (FANTAZZINI \& FARBER, 1989).

\subsubsection{3. "What If"/ "Check List"}

Objetivos - Utilizado nas empresas para avaliar as condições em que se encontram as instalações e equipamentos operacionais, os materiais ou matérias primas transportados ou armazenados na fábrica, e ainda avaliar os procedimentos escritos e praticados por seus empregados.

Descrição geral - Técnica que pode ser aplicada com algum êxito na análise dos riscos de um empreendimento, considerando as fases de projeto, construção ou mesmo a fase final, que é a partida de uma unidade. Porém, sua aplicação é considerada mais útil nas fases de operação normal de uma unidade produtiva e em casos de manutenção preventiva e preditiva. Nesse último caso, a sua aplicação deve ser feita através de manuais pré-elaborados, com os riscos já identificados e que possam precisar de alguma melhoria. Nesse conceito, tornam-se simples e de fácil compreensão e uso pelos operadores

A técnica "What If / Check list" também pode ser utilizada na análise dos riscos existentes nas operações de transporte de produtos, as operações de carga e descarga, as rotas rodoferroviárias, a embalagem, o tipo de veículo e o armazenamento, e o próprio uso feito pelo consumidor de tais produtos.

Tipo e natureza dos resultados - A técnica é aplicável como uma primeira abordagem na análise de risco, tratando-se de um procedimento de revisão de riscos em indústrias de processo e de transformação, e no transporte e armazenamento de produtos. Considera um largo espectro de riscos, envolvendo os vários setores de uma indústria - produção, processo, segurança, materiais e administrativo.

Por possuir uma estruturação e sistemática que a tornam uma técnica exaustiva na detecção do risco, pode produzir relatórios detalhados e de fácil aplicação pelos operadores dos processos envolvidos. Porém, tais relatórios podem também tender a se tornarem extensos e cansativos, apresentando então resultados insatisfatórios. 
Uma das vantagens de sua aplicação nos processos citados é a possibilidade de apoio no desenvolvimento de diretrizes e critérios para a elaboração de normas e procedimentos e práticas operacionais, que visam a redução do risco de acidentes pessoais e operacionais.

É um método puramente qualitativo e preventivo, não considerando o alcance dos efeitos em caso de ocorrência de possiveis acidentes. Este fato é de suma importância na aplicação prática da técnica, quando se considera a variável ambiental.

\subsubsection{Identificação de Perigos e Estudos de Operabilidade - HAZOP}

Objetivos - Identificar riscos e problemas de operabilidade que possam comprometer a capacidade da unidade em alcançar a produtividade do projeto.

Descrição geral - A idéia da análise HAZOP consiste na realização de uma revisão na fábrica, numa série de reuniões, durante as quais uma equipe de conhecimentos ecléticos esquadrinha metodicamente o projeto da fábrica, acompanhando a estrutura formada pelas palavras-guias, orientada pela experiência do chefe da equipe.

A principal vantagem deste trabalho exaustivo é que ele estimula a criatividade, além de gerar idéias. Esta criatividade advém da interação da equipe e de suas diferentes formações. Em conseqüência, o processo exige a participação de todos os membros da equipe (a quantidade gera a qualidade, no caso), devendo estes se abster de críticas recíprocas a fim de que a sugestão de idéias não seja tolhida.

A atenção da equipe concentra-se em pontos específicos do projeto, denominados "nodos de análise", um de cada vez. Em cada um destes "nodos de análise ou estudo", examinam-se os desvios dos parâmetros do processo, com auxílio das palavras-guias. Estas são usadas para se ter a certeza de que o projeto é explorado de todas as maneiras possiveis e imagináveis. Assim, a equipe tem de identificar um número de desvios bem grande, devendo ser cada qual subseqüentemente estudado, a fim de possibilitar a identificação das causas e conseqüências em potencial.

A melhor ocasião para a realização de uma análise HAZOP é a fase em que o projeto se encontra razoavelmente consolidado. Em tal estágio, o projeto já está bem definido, a ponto de permitir a formulação de respostas consistentes às perguntas da análise HAZOP. Além disso, nesta altura ainda é possivel alterar o projeto sem grandes despesas. As análises HAZOP, todavia, podem ser efetuadas em qualquer fase, depois que o projeto estiver quase consolidado. Por exemplo, muitas fábricas mais antigas estão reformulando seus sistemas de controle e instrumentação e, nestes casos, pode ser usada. Existe um relacionamento natural entre o enfoque dos desvios do método HAZOP e a filosofia convencional do projeto de sistemas de controle, baseada na zeragem dos desvios. Portanto, é conveniente que se examine a fábrica assim que o novo projeto do sistema de controle atinja a fase de consolidação.

Tipo e natureza dos resultados - Historicamente, a técnica HAZOP foi desenvolvida para identificar riscos num processo e também os problemas de operabilidade que, embora não perigosos, possam comprometer a capacidade da unidade em alcançar a produtividade conforme o projeto original.

Como as demais técnicas, o HAZOP foi desenvolvido para ser aplicado a projetos que ainda estão na fase de estudo e desenho. No entanto, a técnica vem sendo aplicada com sucesso em unidades existentes e em processos de produção ou transformação. Sua aplicação é própria para indústrias ou processos químicos. Nâo vem sendo aplicada a atividades năo industriais, como o transporte rodoferroviário, e em casos de análise de acidentes ambientais, principalmente por năo prever o alcance do dano ambiental possivel.

Como todas as demais análises de risco, o HAZOP é aplicado ao risco percebido e não ao risco real. 


\subsubsection{Análise de Modos de Falhas e Efeitos - AMFE}

Objetivos - Determinação de falhas de efeito crítico e componentes críticos, análise da confiabilidade de conjuntos, equipamentos e sistemas; revisão sistemática dos modos de falha de um componente, para garantir danos mínimos ao sistema; determinação dos efeitos que tais falhas terão em outros componentes do sistema; determinação dos componentes cujas falhas teriam efeitos críticos na operação do sistema (Falha de Efeito Crítico); determinação de como podem ser reduzidas as probabilidades de falhas de componentes, montagens e subsistemas, através do uso de componentes com confiabilidade alta, redundâncias no projeto, ou ambos.

Descrição geral - A análise de modos de falhas e efeitos (AMFE) consiste numa tabulação dos equipamentos do sistema ou da fábrica, seus modos de falha, o efeito de cada modo de falha sobre o sistema ou sobre a fábrica. Esta técnica nos permite analisar como podem falhar os componentes de um equipamento ou sistema, determinar os efeitos que poderão advir e, consequentemente, estabelecer as mudanças que deverão ser feitas para aumentar a probabilidade de que o sistema ou equipamento realmente funcione de maneira satisfatória.

O modo de falha é uma descrição da maneira pela qual o equipamento falha (abertura, fechamento, ligamentos e desligamentos de circuitos, vazamentos, etc.). $O$ efeito do modo de falha é a resposta do sistema ou o acidente resultante da falha do equipamento. A AMFE identifica os modos isolados de falha que redundem diretamente num acidente de grandes proporçöes, ou que muito contribuam para isso. Os erros humanos, ou de operador, não costumam ser examinados numa AMFE; contudo, os efeitos de uma má operação são geralmente enquadrados num modo de falha de equipamento. A AMFE não é eficiente na identificação de falhas combinadas de equipamento que determinem acidentes. Ela pode ser realizada por dois analistas ou por uma equipe eclética de profissionais.

Tipo e natureza dos resultados - A AMFE apresenta uma listagem sistemática de referência do equipamento, do sistema ou da fábrica, modos de falhas e respectivos efeitos, facilmente atualizável em face de alterações no projeto ou modificações do sistema ou da fábrica. Sua natureza é qualitativa, compreendendo a estimativa tipo "pior caso" das conseqüencias resultantes de falhas isoladas. Contém uma classificação relativa das falhas dos equipamentos, fundamentada na probabilidade de falha e/ou na gravidade do risco (pode ser quantitativa, desde que exista a disponibilidade dos dados de taxas de falhas).

\subsubsection{Análise de Árvore de Eventos - AAE}

Objetivos - Identificar as seqüências de eventos, seguintes a um evento inicial, que resultam em acidentes.

Descrição geral - A análise de ánore de eventos é uma técnica para avaliação dos eventos acidentais potenciais resultantes de falha de um sistema específico de equipamento ou erro humano, conhecido como evento inicial. A AAE considera a resposta do operador ou a resposta do sistema de segurança ao evento inicial na determinação dos eventos acidentais potenciais. Os resultados da AAE säo seqüências de acidentes, ou seja, um conjunto cronológico de falhas ou erros que definam um acidente. Estes resultados descrevem os eventos acidentais potenciais em termos da seqüência de eventos (sucessos ou falhas de funções de segurança) que se seguem a um evento inicial. A AAE é bastante adequada a processos que possuem sistemas de segurança ou procedimentos de emergência que respondem a eventos iniciais específicos.

Tipo e natureza dos resultados - É uma análise qualitativa com potencial quantitativo. Caso os dados de freqüências estejam disponiveis, e em se tratando de uma fonte de alto potencial de risco, tais informações deverão ser contempladas no estudo.

A AAE fornece as seqüências de eventos que resultam em acidentes seguintes à ocorrência de um evento inicial; qualitativa, com potencial quantitativo. A probabilidade esperada das sequiências pode ser quantificada se as probabilidades do evento forem conhecidas. 
A tabela 14 traz um resumo das técnicas de identificação de risco, classificadas como qualitativas, e a sua limitação na análise do risco ambiental.

\subsubsection{Análises de risco quantitativas}

O conhecimento do cenário de um eventual acidente amplia a possibilidade de intervenção, principalmente se forem conhecidos os dados históricos de acidentes em indústrias similares.

O potencial de liberação de matéria e energia deve ser quantitativamente avaliado para determinar os possiveis impactos e conseqüências sobre os meios considerados, no estudo prévio. Isto envolve a realização de um inventário com base nas propriedades das substâncias liberadas, as taxas de liberação, taxas de vaporização e transporte e a possibilidade de dispersão e o comportamento de gases e vapores em determinadas condições meteorológicas.

A modelagem matemática desses fenômenos físicos se torna uma ferramenta essencial para o processo de estimativa de risco. Tais cálculos são baseados em situações simuladas que são incorporadas aos modelos matemáticos, e que levam em conta 0 inventário realizado anteriormente.

A metodologia de análise de risco assim considerada teve origem na indústria nuclear, tendo sido depois adotada pelas indústrias química e petroquímica (GOYAL \& AL-JURASHI, 1990).

$\mathrm{Na}$ indústria siderúrgica, o processo de análise ou quantificação do risco deve ser iniciado considerando-se um evento imaginário, mas provável, envolvendo a perda acidental de material tóxico e/ou inflamável.

Produtos Inflamáveis - A liberação de material inflamável e a sua conseqüente ignição pode causar uma grande variedade de efeitos térmicos e explosivos. Um incêndio, por exemplo, pode causar danos materiais pela radiação térmica liberada; no entanto, o calor gerado seguramente causará danos ambientais e à saúde humana. Casos de incêndio e explosões normalmente causam danos patrimoniais e aos empregados em seus postos de serviço. Raras vezes acontecem incidentes ou acidentes envolvendo a comunidade próxima ou mesmo o meio ambiente.

Ainda considerando um exemplo didático, se o fogo ocorrer próximo a tanques contendo produtos inflamáveis, e se o material construtivo desse tanque entrar em colapso, o seu conteúdo pode ser expelido violentamente e formar um bola de fogo com intensidade explosiva devida à ignição do vapor formado pelo líquido em aquecimento. Nesse caso, poderá ocorrer uma forte e desastrosa radiação térmica.

Gases inflamáveis ou vapores liberados acidentalmente e que são transportados pelo ar ou qualquer meio líquido para longe de suas áreas de produção ou estocagem podem ser ainda mais desastrosos. Isso vai depender de várias situações, dependentes do tipo de material liberado, sua composição, características físicas e químicas, toxicidade, condições do vazamento, condições atmosféricas, direção e velocidade dos ventos, etc.

Produtos tóxicos - Os produtos gasosos ou vapores considerados tóxicos, como já mencionado, podem ser mais desastrosos que alguns incidentes envolvendo explosões e incêndios, isto porque gases/ vapores e mesmo os líquidos vazados podem ser transportados para áreas distantes do seu ponto de liberação, expondo a população e o meio ambiente de uma vasta área.

Tanto o ar atmosférico quanto os rios e lagos são poderosos meios de dispersão daqueles produtos vazados. Dessa forma, o produto poderá ser aspirado ou mesmo ingerido por humanos e outras formas de vida, causando os danos indesejáveis, conseqüentes de uma liberação não controlada ou mesmo de liberaçōes controladas mas de efeito cumulativo, como o caso de 
Tabela 14. Principais objetivos das técnicas de análise de risco qualitativas

\begin{tabular}{|c|c|c|c|}
\hline Técnica & Principios & Vantagens & Limitaçoes \\
\hline APR & $\begin{array}{l}\text { Permite uma revisão geral dos riscos que } \\
\text { estarão presentes nas fases operacionais, } \\
\text { classificando-os para priorização de ações } \\
\text { preventivas }\end{array}$ & $\begin{array}{l}\text { gera um elenco de medidas mitigadoras dos riscos } \\
\text { identificados. Pode ser adaptada para avaliar o risco } \\
\text { ambiental. }\end{array}$ & $\begin{array}{l}\text { não considera o meio atingido } \\
\text { e a severidade do dano }\end{array}$ \\
\hline $\begin{array}{l}\text { "What if/ } \\
\text { Check list" }\end{array}$ & $\begin{array}{l}\text { Procedimento de revisão de riscos de } \\
\text { processo }\end{array}$ & $\begin{array}{l}\text { é um método básico para o desenvolvimento de outras } \\
\text { técnicas de análise. }\end{array}$ & $\begin{array}{l}\text { não considera os aspectos } \\
\text { ambientais }\end{array}$ \\
\hline HAZOP & $\begin{array}{l}\text { Tem por objetivo analisar os riscos } \\
\text { específicos de uma unidade de processo } \\
\text { químico e problemas operacionais }\end{array}$ & $\begin{array}{l}\text { gera elenco de medidas que permitem a redução/ } \\
\text { eliminação dos riscos identificados. }\end{array}$ & $\begin{array}{l}\text { não considera os aspectos } \\
\text { ambientais }\end{array}$ \\
\hline AMFE & $\begin{array}{l}\text { Técnica para deteç̧ão e controle de riscos } \\
\text { oriundos de equipamentos e detecção } \\
\text { precoce de falhas. Identifica componentes } \\
\text { críticos }\end{array}$ & $\begin{array}{l}\text { promove o aumento na confiabilidade dos sistemas } \\
\text { através do tratamento de componentes causadores de } \\
\text { falhas de efeito crítico. } \\
\text { pode incluir os danos ambientais na avaliação dos efeitos } \\
\text { e na classificação dos riscos. }\end{array}$ & $\begin{array}{l}\text { não considera os aspectos } \\
\text { ambientais }\end{array}$ \\
\hline AAE & $\begin{array}{l}\text { Análise semi-quantitativa. Descreve os } \\
\text { eventos potenciais em termos de seqüência } \\
\text { de eventos e considera a resposta humana e } \\
\text { do sistema de segurança }\end{array}$ & $\begin{array}{l}\text { a probabilidade esperada das seqüências de eventos pode } \\
\text { ser quantificada se as probabilidades do evento forem } \\
\text { conhecidas. }\end{array}$ & $\begin{array}{l}\text {-identifica o evento inicial } \\
\text {-não identifica os aspectos } \\
\text { ambientais }\end{array}$ \\
\hline
\end{tabular}


envenenamento de pescadores por ingestão de carne de peixes contaminados com doses elevadas de mercúrio em Minamata, Japão.

As bases, nas quais se determina a magnitude de tais riscos, derivam de uma combinação de dados empíricos e de conceitos puramente teóricos.

Os primeiros passos no processo da análise de risco são a modelagem e a especificação precisa do incidente gerador do incêndio ou da liberação de gases/vapor ou líquidos e o seu padrão de dispersão. Assim, o efeito potencial da liberação, como fogo, detonação, asfixia ou envenenamento, será obtido de modelos de simulação do comportamento dos gases e da sua expectativa de vida, somando-se com o conhecimento das fontes de ignição e os efeitos das diluições sobre a inflamabilidade, toxicidade e a intensidade das radiações térmicas. Os cálculos são complexos e requerem a aplicação de mão obra bastante qualificada e o uso de sistema informatizado de banco de dados e outros recursos matemáticos sofisticados.

As técnicas disponíveis e conceitos básicos que são utilizados para a análise do risco ambiental de um empreendimento, ou de uma fábrica em operação e dos demais processos envolvidos armazenamentos, distribuição, manipulação, transportes, etc., estão relacionadas a seguir:

- análise de árvore de falhas

- análise de conseqüências

- estimativa da freqüência

- análise de vulnerabilidade

- estimativa de probabilidade

O produto final da aplicação dessas técnicas é a apresentação de um cenário para a eventualidade de um acidente na produção, estocagem, transporte, distribuição e mesmo o consumo de um dado produto considerado perigoso quanto à sua inflamabilidade, toxicidade e explosividade.

\subsubsection{Análise de Ávore de Falhas - AAF}

Objetivos - Obtenção, através de um diagrama lógico, do conjunto mínimo de causas (falhas) que levariam ao evento em estudo; obtenção da probabilidade de ocorrência do evento indesejado.

Descrição geral - A Análise da Árvore de Falhas (AAF) é uma ferramenta para a análise da segurança de sistemas amplamente usada. Um dos principais pontos fortes do método reside no desenvolvimento lógico e sistemático das muitas falhas que podem resultar em um acidente. Este tipo de desenvolvimento exige do analista uma perfeita compreensão da operação do sistema ou da fábrica e dos vários modos de falhas dos equipamentos.

A AAF desdobra um acidente em seus elementos contribuintes, representados por falhas de equipamentos e erros humanos. O método constitui, portanto, uma técnica de "pensamento inverso", ou seja, o analista começa com um acidente ou evento indesejável, que deve ser evitado, e identifica as causas imediatas do evento. Cada uma das causas imediatas é examinada sucessivamente até que o analista identifique as causas básicas de cada evento. $A$ árvore de falhas é um diagrama que aponta as interrelações lógicas entre estas causas básicas e 0 acidente.

O resultado da AAF é uma lista de combinações de falhas de equipamentos e de falhas humanas suficientes para ocasionar 0 acidente. Estas combinações de falhas denominam-se conjuntos de cortes mínimos ("minimal cut sets"). Cada conjunto destes representa o menor conjunto de falhas humanas e de equipamentos suficientes para causar o acidente, quando todas as falhas deste conjunto e de corte mínimo ocorrerem simultaneamente. Assim, um conjunto de corte mínimo é logicamente equivalente ao acidente indesejável, ou "evento topo", expresso em termos das falhas de equipamentos e dos erros humanos. 
Tipo e natureza dos resultados - A análise deverá ser quantitativa, através da determinação das freqüências de ocorrência dos eventos indesejados, conhecidos como eventos topo, no caso das fontes de alto potencial de risco.

\subsubsection{Avaliação de Conseqüências}

Objetivos - $O$ objetivo da modelagem matemática das conseqüências de um dado eventos é produzir um mapa da região em estudo, onde estarão assinalados os efeitos físicos (radiações térmicas, sobrepressões e vazamentos tóxicos) levantados no processo de identificação dos riscos ambientais.

Descrição geral - A previsão do comportamento de uma liberação ou vazamento acidental de produto quimico durante a sua produção, distribuição, armazenamento ou transporte e as suas conseqüências envolve basicamente três estágios de estudos:

- Avaliação da fonte: envolve o conhecimento de todos os dados existentes sobre a fonte da liberação ou vazamento. Esses dados referem-se à capacidade do tanque ou do processo, a quantidade estocada no momento do incidente, a quantidade de produto vazada, as possiveis reações secundárias do produto com o meio receptor, as características físicas e químicas do produto, e as condições termodinâmicas do produto que entra na atmosfera.

- Avaliação do meio receptor: envolve o conhecimento dos dados referentes ao meio de dispersão do produto vazado ou liberado. Esses dados referem-se às condições de dispersão no meio considerado, às características e composição natural desse meio, às condições ambientais e a previsões climatológicas no momento do incidente.

- Avaliação da vulnerabilidade: envolve o conhecimento dos dados referentes aos efeitos dos produtos liberados ou vazados e suas possíveis reações secundárias com o meio receptor sobre a saúde humana, o patrimônio social e institucional, o meio geofísico e os ecossistemas da região sob influência do evento.

Para a modelagem das conseqüências, dados tais como: fase em que ocorreu o vazamento (líquida, gasosa ou bi-fásica), tipo de vazamento (contínuo ou instantâneo), descarga de líquido (pressurizado ou não), descarga de gás, atomização, duração do evento, quantidade vazada, densidade do gás ou do líquido superaquecido, e que estão intimamente ligados à produção, estocagem, transporte e distribuição do produto envolvido, influenciam determinantemente na concentração do produto nas regiōes circunvizinhas ao local do incidente.

Tipo e natureza dos resultados - Como mencionado anteriormente, o produto da estimativa das conseqüências de um acidente identificado através das técnicas de análise de risco é um mapa onde estão representados o cenário calculado da área passivel de ser atingida pelo vazamento, a determinação da natureza do evento, o cálculo de fluxo térmico ou da sobrepressão e do número de fatalidades em cada cenário avaliado.

\subsubsection{Estimativa de Freqüência}

Objetivo - O objetivo básico desta técnica é contribuir para a execução da avaliação de risco através da compilação dos dados existentes sobre a confiabilidade dos componentes do sistema avaliado e desenvolver os modelos lógicos-matemáticos.

Descrição geral - É uma técnica disponível para a análise de problemas em equipamentos relacionados a setores determinados de um sistema e não a eventos específicos que possam ser hierarquizados. Desta forma, apresenta deficiências intrínsecas para o trabalho que envolve 0 risco de um acidente com danos ambientais.

Os dados para compor o estudo referem-se à confiabilidade de um determinado equipamento e envolve a sua taxa de falhas, conforme utilizado na AMFE. Essa taxa de falhas revela o número de vezes que um determinado equipamento, peça ou operação pode falhar. Essa falha é posteriormente avaliada pela AMFE e determina então o risco estatístico de ocorrer um determinado evento. 
Tipo e natureza dos resultados - Os resultados deste estudo são apresentados em função da avaliação da freqüência com que um evento pode ocorrer. A sua utilidade está fundamentalmente na contribuição que esses dados podem fornecer para outras técnicas de identificação e avaliação de risco, assegurando ao analista números que podem ser comparados com dados de acidentes já ocorridos e, desta forma, validar os seus próprios estudos e resultados.

\subsubsection{Análise de vulnerabilidade}

Objetivo - A análise de vulnerabilidade é um processo dos mais importantes dentro da análise de risco ambiental. Ela deve considerar toda a composição dos meios biogeofísico e sócioeconômico na área de influência de uma fábrica, e utilizar-se de recursos da modelagem matemática que permitam estimar os danos à saúde humana, aos ecossistemas e meios geofísicos, bem como às propriedades públicas e institucionais, decorrentes de um acidente com liberação de um produto, incêndio ou explosão conseqüentes.

Descrição geral - A estimativa da vulnerabilidade de uma determinada área e de seus componentes biogeofísicos e sócio-econômicos é feita através do levantamento prévio dos dados que envolvem esses meios. Esses dados devem considerar, entre outros, os seguintes dados:

- característica físicas e químicas dos corpos receptores (ar, água e solo);

- formas de transporte e dispersão desse corpos;

- ecossistemas definidos para a área e corpos receptores;

- patrimônios ecológicos e sociais;

- economia do local;

- bens e recursos públicos e privados;

- estradas e meios de transporte;

- patrimônio da empresa;

- dados relativos à estrutura dos prédios da fábrica;

- sistemas de prevenção e controle de acidentes;

- seguros;

- mapas detalhados da região;

- dados populacionais;

- recursos para ações emergenciais;

- planos de evacuação;

- etc.

A análise de vulnerabilidade é uma ferramenta que deve ser aplicada em conjunto com a estimativa de conseqüências de um acidente catastrófico onde os dados compilados são tratados estatisticamente e as informações são aproveitadas para a avaliação dos riscos, em conjunto com os dados de outros levantamentos realizados. Evidentemente, para a análise conjunta deverá ser considerada a hipótese de uma liberação ou vazamento de um produto tóxico e que possa ultrapassar os limites da fábrica e atingir os meios citados.

Tipo e natureza dos resultados - O resultado obtido nesta análise é a apresentação de dados que evidenciam a composição dos meios existentes na área de influência de um determinado processo. Essa composição evidenciará também a distribuição geográfica e temporal da população do local e a infra-estrutura que poderá ser afetada por um incidente.

\subsubsection{Estimativa de probabilidade}

Objetivo - Avaliar a probabilidade de ocorrência de um determinado evento, considerado na identificação do risco.

Descrição geral - Todas as análises e avaliações propostas só serão completas se contiverem um estudo corroborado por cálculos que determinem a probabilidade de ocorrer o evento considerado. 
Um evento classificado como catastrófico nas etapas anteriores só terá significado se a probabilidade de ocorrer não for muito pequena. Da mesma forma, acidentes com pequenas conseqüências, mas com alta probabilidade de ocorrência, não são importantes na análise geral do risco. Assim, o conhecimento da probabilidade de conseqüências potenciais devidas à natureza da ocorrência e à sua magnitude deverão ser determinadas nas análises prévias.

A probabilidade de ocorrer o evento gerador do dano potencial máximo será computada, segundo DE CICCO \& FANTAZZINI (1985), através das duas formas abaixo:

- pela estimativa qualitativa, baseada em experiência anterior, em casos análogos e nos dados disponíveis na empresa. A essa estimativa qualitativa será atribuido um valor entre 0,01 e 1,00 e que inclui uma classificação qualitativa do evento - remoto, ocasional, razoavelmente provável, provável e altamente provável;

- pelo cálculo efetuado, utilizando-se estatisticas representativas do evento analisado, ou pelo desenvolvimento de análises quantitativas, como por exemplo a AAF. Nesse caso, a probabilidade poderá variar de forma contínua, entre 0 e 0,1 .

A probabilidade de ocorrer um evento ou a falha de determinado componente, ou mesmo de uma operação, pode ser associada a uma variedade de níveis de danos e ações. Na liberação de um gás explosivo ou tóxico pode haver muitas variáveis (direção e velocidade do vento, presença do operador para controlar o evento, distribuição da população, etc.) que certamente interferirão no número de pessoas expostas a algum risco ou dano. Cada um desses fatores inclui em si um fator probabilístico, que deve ser incorporado aos cálculos efetuados.

Tipo e natureza dos resultados - Os resultados quantificados dos danos e a sua probabilidade associada, calculados para cada cenário encontrado nas análises de identificação de risco, formam o escopo básico de uma detalhada e compreensiva avaliação de risco. Os cálculos finais deverão ser aproximados, pois tanto os dados existentes quanto os modelos utilizados no processamento do cenário final estão sujeitos a simplificações e erros estatísticos marginais.

A tabela 15 resume as técnicas de identificação de risco, classificadas como quantitativas, e a sua limitação na análise do risco ambiental. 
Tabela 15. Principais objetivos das técnicas quantitativas de análise de risco

\begin{tabular}{|c|c|c|c|}
\hline Técnica & Princípios & Vantagens & Limitaçóes \\
\hline$\overline{\mathrm{AAF}}$ & $\begin{array}{l}\text { técnica quantitativa que aborda lógica e } \\
\text { sistematicamente um evento altamente } \\
\text { indesejado }\end{array}$ & $\begin{array}{l}\text { pode fornecer a probabilidade de ocorrência de um } \\
\text { evento. Bom para sistemas complexos onde outras } \\
\text { técnica são inoperantes }\end{array}$ & $\begin{array}{l}\text { não considera os aspectos } \\
\text { ambientais }\end{array}$ \\
\hline $\begin{array}{l}\text { Avaliação de } \\
\text { conseqüências }\end{array}$ & produzir um mapa da região em estudo & $\begin{array}{l}\text { previsão do comportamento de um vazamento ou } \\
\text { liberação de produto químico perigoso }\end{array}$ & $\begin{array}{l}\text { Pode requerer uso de modelos } \\
\text { matemáticos complexos }\end{array}$ \\
\hline $\begin{array}{l}\text { Estimativa de } \\
\text { freqüência }\end{array}$ & $\begin{array}{l}\text { avaliação do risco através da compilação de } \\
\text { dados existentes sobre a confiabilidade dos } \\
\text { componentes }\end{array}$ & $\begin{array}{l}\text { contribui para a conclusão de outras técnicas } \\
\text { através da quantificação e dados comparáveis }\end{array}$ & $\begin{array}{l}\text { análise de sistema com pouca ou } \\
\text { nenhuma relação com os aspectos } \\
\text { ambientais }\end{array}$ \\
\hline $\begin{array}{l}\text { Análise de } \\
\text { vulnerabilidade }\end{array}$ & $\begin{array}{l}\text { utiliza recursos de modelagem matemática } \\
\text { para estimar os riscos ao meio ambiente, } \\
\text { saúde do trabalhador e patrimônio }\end{array}$ & aplicável para avaliação dos riscos ambientais & $\begin{array}{l}\text { grande número de dados } \\
\text { necessários para compor a análise }\end{array}$ \\
\hline $\begin{array}{l}\text { Estimativa de } \\
\text { probabilidade }\end{array}$ & $\begin{array}{l}\text { determina a probabilidade de ocorrer um } \\
\text { determinado evento }\end{array}$ & $\begin{array}{l}\text { pode ser usado agregado a técnicas quali e } \\
\text { quantitativas }\end{array}$ & - \\
\hline
\end{tabular}




\subsection{PROPOSTA DE METODOLOGIA APROPRIADA PARA A ANÁlise DE RISCO AMBIENTAL}

Após os sérios acidentes industriais nacionais e internacionais ocorridos, com perdas humanas e abalos comerciais sensiveis nas instituições envolvidas nos acidentes, os estados membros da Comunidade Européia editaram, em 1982, a Diretriz de Seveso, que tinha como aplicação prática avaliar os riscos inerentes aos procedimentos de transformação ou de tratamento de substâncias químicas, assim como as operações de armazenamento de produtos em função da quantidade estocada e os riscos que poderiam apresentar dentro de uma zona de 500 metros. Na França, em 1985 o Ministério do Meio Ambiente identificou 325 instalações que se enquadravam nas premissas da Diretriz de Seveso. Incluídas nesse número estavam as instalaçōes siderúrgicas, principalmente as usinas integradas, em conseqüência dos processos: armazenamento e distribuição de gás de coqueria, altos fornos, circuitos de recuperação de gases dos conversores, área de carboquímicos (subprodutos da coqueria), estocagem de gases (altos fornos e combustiveis) e óleos combustiveis (ANTOINE, 1988). Evidentemente, esses números cresceram, porém o fato de terem sido legalmente identificadas na França as atividades da indústria siderúrgica como de risco maior, isto é, apresentarem os riscos de explosão, incêndio e vazamento de produtos quimicos, induziu as autoridades a avaliarem os riscos presentes nessa atividade.

Entretanto, como já mencionado, a Diretriz de Seveso não considera a sensibilidade ambiental como um dos aspectos a serem avaliados nas análises de risco. Entretanto, os impactos das atividades antrópicas nos recursos naturais devem ser considerados (medidos e avaliados), levando-se em conta o ecossistema natural que é dinâmico no espaço e no tempo.

Segundo BARTELL (1996), as principais fontes de risco ecologico estão ligadas à presença de substâncias compostas ou contendo metais tóxicos $(\mathrm{Hg}, \mathrm{Cd}$, Se, $\mathrm{As}, \mathrm{Ni})$, produtos orgânicos (ascarel e hidrocarbonetos poli-aromáticos) e defensivos agricolas, conforme apresentado na Tabela 16.

No mesmo estudo, BARTELL (1996) aponta que os meios mais impactados pelos produtos químicos gerados nas atividades humanas são as águas superficiais e os sedimentos, com $85 \%$ do total dos meios expostos. A tabela 17 apresenta os valores evidenciados pelo autor.

Tabela 16. Principais componentes geradores de riscos ecológicos (seg. BARTELL, 1996)

\begin{tabular}{l|c}
\hline Componentes & Porcentagem \\
\hline Metais tóxicos & 28 \\
Compostos orgânicos & 27 \\
Resíduos não especificados & 20 \\
Defensivos agricolas & 15 \\
Outros & 10 \\
\hline
\end{tabular}

Tabela 17. Meios fisicos expostos a produtos químicos (seg. BARTELL, 1996)

\begin{tabular}{l|c}
\hline Meio fisico & Porcentagem \\
\hline Águas superficiais & 53 \\
Sedimentos & 32 \\
Solos & 12 \\
Outros (vegetação, água subterrânea, ar) & 19 \\
\hline
\end{tabular}

Considerando os meios expostos, pode-se concluir que as populações de peixes, fitoplâncton, zooplâncton e organismos bentônicos são as mais sujeitas ao risco de comprometimento e danos ambientais. As próximas populações expostas são os pássaros e as plantas (terrestres e aquáticas). 
Dos resultados apresentados por BARTELL (1996), pode-se inferir que os meios físicos mais atingidos pelas atividades humanas são as águas superficiais e os sedimentos, portanto um complexo íntima e diretamente relacionados, pois os efeitos negativos das atividades descritas ocorrem primeiramente no corpo hídrico, indo sofrer um processo de acumulação e biodisponibilidade nos sedimentos. Evidentemente, as populações que povoam esse ecossistema são as mais direta e prontamente atingidas. Torna-se evidente, portanto, considerar a presença desses sistemas naturais nas análises de risco, desde a simples identificação do risco até as análises quantitativas mais refinadas.

No Brasil não há, explicitamente, a exigência legal de realização de uma análise de risco ambiental para qualquer processo que apresente risco de acidentes maiores. A sua realização é de inteira responsabilidade do empreendedor, que deve reconhecer o potencial de risco de suas atividades, contratar ou treinar técnicos para a sua realização, definir a aceitabilidade dos riscos identificados e manter o gerenciamento dos riscos aceitáveis. Para tanto, é necessário ter ferramentas desenvolvidas que forneçam ao empreendedor e aos órgãos de fiscalização condições de tomar decisões claras e fundamentadas para a aceitação dos riscos relativos ao patrimônio, à saúde do trabalhador e ao meio ambiente. As técnicas de análise de riscos de segurança atendem a partes do trinômio patrimônio/saúde/meio ambiente, preterindo sempre o meio ambiente. A realização de várias técnicas semelhantes para atingir um só objetivo transforma-se em perda de tempo e dinheiro, levando o administrador a realizar o trabalho incompleto ou a não realizá-lo.

O objetivo deste trabalho é propor uma ou mais técnicas de análise de risco que permitam ao administrador incorporar o trinômio avaliado numa só técnica, incorporando nas técnicas já existentes à variável ambiental. Para tanto, é feita uma análise e avaliação das informações e conceitos elaborados nos itens anteriores, confrontando as situações evidenciadas em práticas de campo e publicações técnicas consultadas.

De qualquer forma, a estrutura de um estudo de análise de risco não deverá se afastar das etapas, já apresentadas anteriormente, e que envolvem:

a. identificação do grau de risco do empreendimento

b. definição das hipóteses de acidentes

c. estimativa da probabilidade/avaliação das conseqüências das hipóteses de acidentes definidas

\subsubsection{Identificação do grau de risco do empreendimento}

A primeira etapa objetiva caracterizar o grau de risco, ou nível de periculosidade, de uma operação industrial ou do armazenamento e transporte de substâncias químicas perigosas.

No item 3.1, foi apresentado um resumo das técnicas disponíveis e a sua aplicabilidade a uma análise de risco ambiental. A existência de diversas metodologias para a classificação da potencialidade de geração de um acidente ou incidente permite ao empreendedor ou administrador avaliar o grau de risco que sua atividade apresenta ou poderá apresentar, a partir dos fatores de sensibilidade das áreas circunvizinhas ao processo, aos produtos manipulados e/ou armazenados, e às condições dos processos de produção, manuseio e armazenamento.

Entre as técnicas apresentadas, a CATBRAS (MAKARON, 1992) é a que melhor se adapta às necessidades de identificação dos riscos de uma siderúrgica, tendo sido aplicada em uma indústria siderúrgica do Estado de $S$. Paulo, para a classificação do risco de 14 diferentes setores, com bons resultados (PEREIRA \& PEDRO, 1992, 1993).

\subsubsection{Metodologia}

A metodologia classifica as fontes e atividades potencialmente geradoras de acidentes ambientais de acordo com o risco para a população e o meio ambiente, em quatro grupos, como segue:

- Classe I: Alto Potencial de Risco

- Classe II: Médio Potencial de Risco

- Classe III: Baixo Potencial de Risco

- Classe Especial de Risco 
As classes I, II e III aplicam-se aos processos industriais e armazenamento de substâncias tóxicas, inflamáveis e/ou explosivas, de acordo com a metodologia descrita. A cada classe de risco corresponderá um método de análise.

Considera-se como fontes e atividades pertencentes à Classe Especial de Risco aquelas que, em função de suas peculiaridades operacionais e localização, configurem sempre um alto potencial de risco, independentemente da natureza e quantidade das substâncias envolvidas. Portanto, as fontes e atividades pertencentes a esta classe necessitam um estudo de análise e avaliação dos riscos completo e detalhado. Estão incluídos nesta classe: terminais marítimos de gases e granéis líquidos; sistemas de dutos; plataformas de petróleo e gás; navios e barcaças, e portos.

O método limita-se à classificação de processos industriais e armazenamento de substâncias tóxicas, inflamáveis e/ou explosivas, em particular: fábricas de produtos quimicos orgânicos e inorgânicos; processos de destilação e refino de petróleo e derivados; processos de produção e tratamento de gases; armazenamentos fixos e/ou temporários como tanques, cilindros, caminhões-tanque e "containers".

O método estabelece critérios para a classificação de processos e armazenamento. Esta classificação é realizada através de duas etapas.

Numa etapa inicial, são fornecidos critérios para a classificação das fábricas de acordo com a periculosidade das substâncias; esta é função dos parâmetros: tipo de substância envolvida, quantidade da mesma e condições do processo e/ou de armazenamento. Nesse ponto tem-se, por exemplo, que duas fábricas que utilizem a mesma substância, com a mesma quantidade e em iguais condições de processo, são classificadas numa mesma classe, sem considerar a sua localização. Numa etapa subsequente, são feitas, para a área em questão, considerações como: densidade populacional, presença de serviços públicos, existência de rodovias, aeroportos e outros. Desta forma, o resultado é a classificação das fábricas, processos e armazenamento quanto aos riscos para a população e o meio ambiente.

São especificados três critérios para a classificação das fábricas, processos e armazenamento de acordo com a periculosidade da substância:

1. Quanto ao tipo de substância no processo e armazenamento - São aqui considerados três tipos de substâncias perigosas: substâncias tóxicas, substâncias explosivas, e substâncias inflamáveis.

O critério de classificação das substâncias é feito através de níveis de periculosidade (periculosidade em relação a toxicidade, a explosividade ou a inflamabilidade). $O$ parâmetro que define este nivel varia com o tipo de substância.

Em função do valor do parâmetro avaliado em cada caso, as substâncias são distribuídas em quatro níveis de periculosidade, no caso das substâncias tóxicas e inflamáveis, e em três níveis de periculosidade no caso das substâncias explosivas.

Na tabela 18 mostra-se o resumo dos critérios mencionados acima.

Tabela 18. Parámetros de definição dos niveis de periculosidade (seg. MAKARON, 1992)

\begin{tabular}{l|l}
\hline Tipo de substáncia & \multicolumn{1}{|c}{ Parâmetros de definição dos niveis de periculosidade } \\
\hline Tóxica & $\mathrm{DL}_{50}$ e/ou $\mathrm{CL}_{50}$ \\
\hline Explosiva & Sensibilidade: \\
& $\begin{array}{l}\text { - ao calor } \\
\text { - ao choque } \\
\text { e taxa máxima de detonação }\end{array}$ \\
\hline Inflamável & Ponto de fusão e ponto de ebulição \\
\hline
\end{tabular}


2. Quanto à quantidade de substância nas fábricas, processos e armazenamento: Para efeito deste método, considera-se como a massa contida na fábrica a soma da capacidade nominal de cada unidade ou sistema com a quantidade estimada nas linhas de cada substância envolvida no processo ou de armazenamento. Além disso, para cada nível de periculosidade definido para cada tipo de substância é associada uma Massa Crítica Característica do nível, ou seja, a quantidade de substância a partir da qual a fábrica configura um alto potencial de risco.

Substáncias tóxicas - A Massa Crítica de cada substância é estabelecida a partir da Massa Crítica Caracteristica do nivel a que pertence.

Substancias explosivas - A Massa Crítica de todas as substâncias dentro de um mesmo nível é igual à Massa Crítica Caracteristica deste.

Substâncias inflamáveis - A Massa Crítica de todas as substâncias dentro de um mesmo nível é igual à Massa Crítica Característica deste.

3. Quanto às condiçסes de processo e armazenamento: As condições de processo e de armazenamento são consideradas estabelecendo-se fatores de correção que variam de acordo com a situação específica da planta e que atuam sobre a quantidade de material perigoso contido na mesma, obtendo-se, assim, uma quantidade corrigida de substância que é posteriormente confrontada com os limites pré-estabelecidos (Massa Crítica) da substância em questão.

Ao final desta primeira etapa, são gerados dois grupos, conforme a presença, ou não, de substâncias perigosas processadas ou armazenadas nas fábricas em quantidades superiores a valores pré-estabelecidos.

Os critérios envolvidos na classificação das fábricas, processos e armazenamento quanto ao risco para a população e o meio ambiente são aqueles que expressam a sensibilidade da área circunvizinha à fábrica em questão, tais como densidade populacional, presença de serviços públicos ou aeroportos, etc..

Esses novos critérios são reunidos através da definição de área sensivel a uma fábrica localizada na mesma.

O resultado desta segunda etapa é a classificação das fábricas, processos ou armazenamento em três classes, de acordo com o risco para a população e o meio ambiente.

O procedimento geral destas etapas está ilustrado na figura 13.

A partir desses conceitos, é feita a classificação das fábricas de acordo com a sua periculosidade. Foram considerados, nessa fase, o tipo, a quantidade da substância e características do processo/ armazenamento. $O$ resultado desse procedimento foi a classificaçăo das fábricas de acordo com a periculosidade das substáncias presentes nas mesmas.

No caso de fábricas, processos ou armazenamento, essa primeira etapa pode ser apresentada sucintamente como segue:

- Classificação das substâncias em níveis de periculosidade de acordo com parâmetros definidos para cada classe de substância (tóxica, inflamável ou explosiva).

- Definição da Massa Crítica da substância $\left(M_{c}\right)$ de acordo com o nivel de periculosidade da substância.

- Obtenção de uma Massa Crítica Final $\left(M_{c f}\right)$ que considera que uma substância pode apresentar simultaneamente caracteristicas tóxica, inflamável e/ou explosiva.

- Correção da quantidade de substância contida na fábrica $(M)$, com fatores (f) que consideram situaçōes especificas do processo ou do armazenamento de cada fábrica.

Massa corrigida $\left(M^{\prime}\right)=M^{*} f$

- Confronto entre os valores de massa corrigida contida na fábrica ( $\left.M^{\prime}\right)$ e Massa Crítica Final $\left(M_{\mathrm{ff}}\right)$.

No caso em que

$M^{\prime} \geq M_{c f}$

a fábrica é configurada como um alto potencial de risco. 
Figura 13.Procedimento geral para classificação de fábricas, processos e armazenamento (segundo MAKARON, 1992)

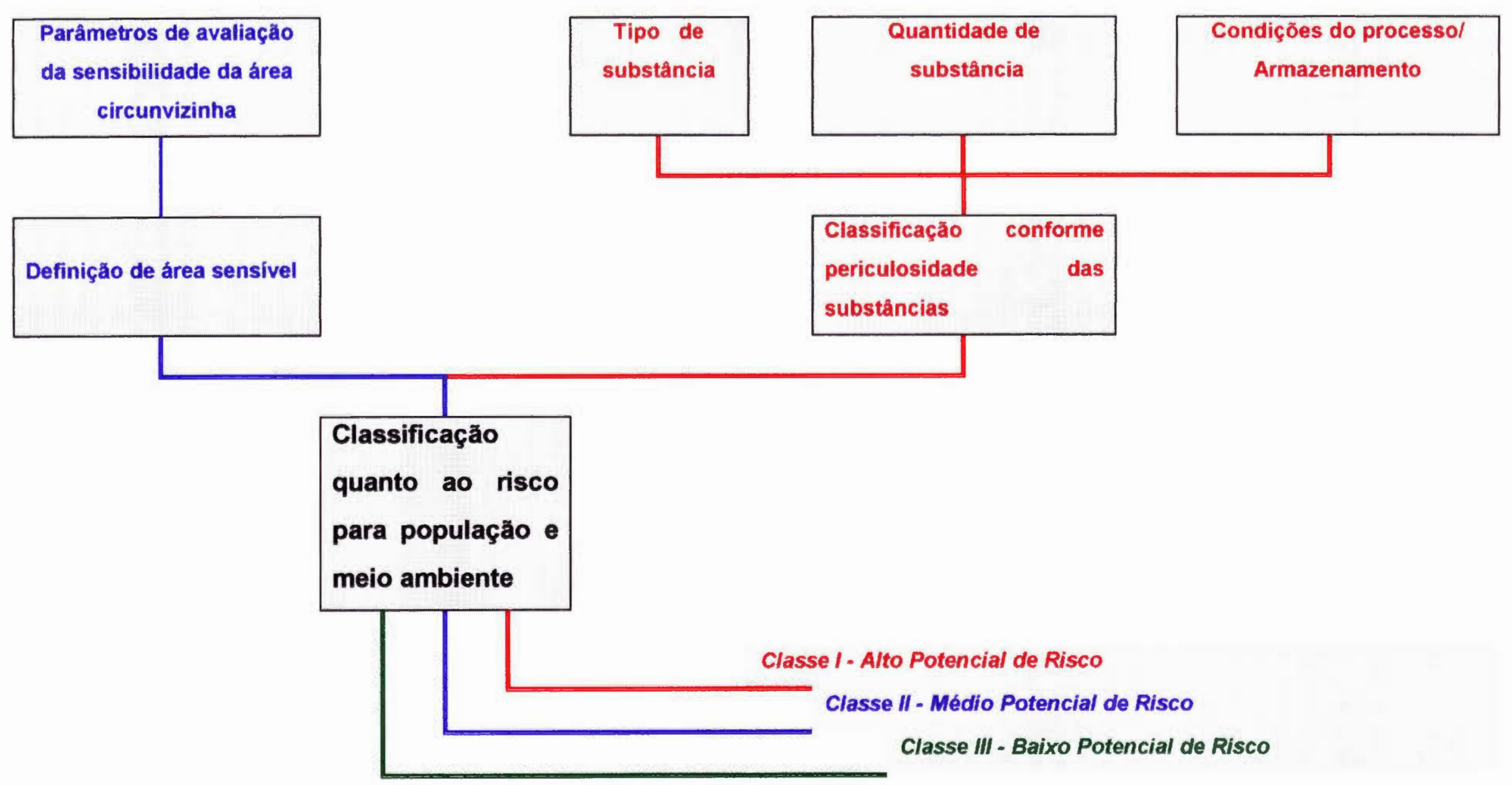


Numa segunda etapa, deve-se agora acrescentar às condições feitas acima, novos critérios que permitam a classificaçăo das fábricas de acordo com o risco para a populaçăo e o meio ambiente.

A preocupação relativa com um evento está relacionada a dois elementos: magnitude das consequências do evento, e freqüência de ocorrência do evento.

Os critérios da segunda etapa expressam basicamente a sensibilidade da área circunvizinha à fábrica em questão, ou seja, considerações como densidade populacional, presença de serviços públicos, sistemas viários e outros. Essas considerações podem incrementar o risco, seja por aumento da freqüência de ocorrência, seja por incremento das consequências, não sendo possivel distribuir as fábricas em classes de risco sem uma análise preliminar da situação derivante desses fatores externos.

Para as várias situações propostas, é geralmente necessária a determinação de parâmetros de avaliação da sensibilidade da área circunvizinha, como por exemplo qual é a distância de interesse, isto é, até que distância os efeitos de um vazamento tóxico, de um incêndio ou de uma explosão são sentidos de forma relevante. Através de pesquisas a bancos de dados internacionais de acidentes, adotou-se um valor de distância de interesse de $5 \mathrm{~km}$ para a maioria das hipóteses descritas. As exceções são assinaladas e justificadas conforme o caso. Todas as distâncias consideradas devem ser medidas a partir do baricentro da fábrica.

São os seguintes os parâmetros utilizados para verificação da sensibilidade da área circunvizinha:

1. Densidade populacional

1.1. A densidade populacional é maior que $300{ }^{(1)}$ pessoas por $\mathrm{km}^{2}$, considerando-se uma área com raio de $5 \mathrm{~km}$ ?

1.2. Existem concentrações de população maiores que $1000^{(2)}$ pessoas a uma distância menor que $5 \mathrm{~km}$ da fábrica?

\section{2. Áreas industriais}

2.1. Existem fábricas ou outras atividades industriais que configuram um alto potencial de risco, ou seja, fábricas com $M^{\prime} \geq M_{\mathrm{cf}}$ a uma distância menor que $1^{(3)} \mathrm{km}$ ?

\section{Serviços públicos}

3.1. Existem concentrações de população de alto risco (hospitais, escolas, asilos, etc.) a uma distância menor que $5 \mathrm{~km}$ ?

3.2. Existem pontos com concentração transitória de população (estações ferroviárias, rodoviárias, estádios esportivos, etc.) a uma distância menor que $1^{(4)} \mathrm{km}$ ?

\section{Sistemas viários e aeroportos}

4.1. Existem rodovias com grande movimentação de veículos ou ferrovias a uma distância menor que $500^{(5)} \mathrm{m}$ dos limites da fábrica? da fábrica?

4.2. Existem aeroportos a uma distância menor que $5 \mathrm{~km}$, que apresentem rotas por cima

De uma forma geral, pode-se dizer que os itens 1 e 3 são fontes potenciais de um incremento de magnitude do evento, uma vez que descrevem uma maior população exposta ao risco. $O$ item 4 pode ser fator de incremento da freqüência de acidentes, enquanto que o item 2 apresenta uma conjugação dos dois fenômenos, já que sua conseqüência predominante é o efeito "dominó", ou seja, o risco que um acidente em uma fábrica possa propagar-se a outras.

A área na qual está situada uma fábrica será considerada sensível se uma ou mais das situações descritas no item anterior possam existir, ou seja, no caso de resposta positiva a um ou mais parâmetros que avaliam a sensibilidade da área circunvizinha à fábrica em questão.

[NOTA: (1) - valor médio considerado para indicação de concentração urbana; (2) - valor assumido como presença urbana significativa; pode ocorrer que a área com raio de $5 \mathrm{~km}$ apresente densidade populacional menor que o valor médio de concentração urbana admitido e que exista uma área interna e esta com densidade populacional igual ou maior que a considerada; 
(3) - o efeito "dominó" em geral é verificado até uma área de $1 \mathrm{~km}$, não atingindo valores tão altos de distância como o estipulado para a distância de interesse de $5 \mathrm{~km}$; (4) - a distância foi reduzida para considerar o fato que este tipo de população não é permanente na área circunvizinha ao local do acidente; (5) - para os sistemas viários, quando geradores de eventos perigosos, a distância de interesse significa até que distância estes poderiam provocar algum acidente no interior da fábrica; consequentemente, a distância de interesse deve apresentar um valor bem inferior aos $5 \mathrm{~km}$ inicialmente estabelecido.]

\section{Classe de risco das unidades de processo e armazenamento}

A partir dos resultados obtidos na $1^{\text {a }}$ etapa, as fábricas são separadas em dois grupos em função de um confronto entre a Massa Crítica Final $\left(\mathrm{M}_{\mathrm{cf}}\right)$ e a massa da substância perigosa corrigida ( $\left.\mathrm{M}^{\prime}\right)$ presente na fábrica, ou seja:

$$
\begin{aligned}
& M^{\prime} \geq M_{c f} \\
& M^{\prime}<M_{c f}
\end{aligned}
$$

As fábricas do primeiro grupo são consideradas de alto potencial de risco, independentemente das características da área circunvizinha às mesmas, isto é, a periculosidade das substâncias associada às condições internas da fábrica são suficientes para criar uma situação de alto risco. 0 mesmo não pode ser afirmado para fábricas cujas quantidades são inferiores aos limites estabelecidos. Neste caso, o grau de periculosidade é influenciado pelas características da área circunvizinha, de forma que são estabelecidas classes de risco através da combinação entre o valor da massa corrigida presente na fábrica e característica da área externa ao estabelecimento.

As fábricas do segundo grupo, a menos que apresentem massas corrigidas muito inferiores à Massa Crítica Final $\left(M_{c f}\right)$ estipulada, podem também gerar situações de risco elevado. Adotou-se $10 \%$ da Massa crítica como sendo o valor da massa corrigida que, independentemente das condições externas, não é capaz de configurar um alto risco.

Fábricas com quantidades inferiores a esse valor limite $\left(10 \% M_{\mathrm{cf}}\right)$ e localização em área não sensivel devem configurar a classe de risco mais baixa. No caso em que estas fábricas estejam situadas em uma área sensível, é gerada uma classe de risco intermediário, pois, apesar da sensibilidade da área, a quantidade de massa presente na fábrica é muito baixa para ocasionar um grande risco. Essa classe engloba também fábricas com massas corrigidas maiores que $10 \%$ da Massa Crítica e localização em áreas não sensiveis.

As fábricas podem, então, ser classificadas, conforme o risco para a população e o meio ambiente, em três niveis de periculosidade ou classes de risco, conforme apresentado no diagrama lógico da figura 14.

Nivel I: fábricas que configuram um alto potencial de risco. Enquadram-se nesta categoria as fábricas que apresentam $M \prime / M_{\mathrm{cf}} \geq 1$, independentemente da sensibilidade da área, ou $0.1 \leq$ $M^{\prime} / M_{c f}<1$, situadas em área sensível

Nível II: Fábricas que configuram um risco médio, isto é, embora o risco associado não seja definido como um alto potencial de risco, estas fábricas podem provocar situações de risco consideráveis. Enquadram-se nesta categoria as fábricas que apresentam $0.1 \leq M^{\prime} / M_{c t}<1$, situadas em área não sensivel, ou $M^{\prime} / M_{\mathrm{cf}}<0.1$, situadas em área sensível.

Nível III: Fábricas que configuram um risco baixo. Este risco é inerente ao mínimo que sempre é associado a uma determinada atividade. Enquadram-se nesta categoria as fábricas que apresentam $M^{\prime} / M_{c t}<0.1$, situadas em área não sensível.

\subsubsection{Análise da metodologia CATBRAS}

Conforme pode ser observado na discussão da técnica indicada para classificação do risco de uma atividade em função de seu processo operacional ou de armazenamento de produtos químicos, o método se propõe a classificar as unidades conforme a periculosidade das substâncias presentes (avaliando o tipo e quantidade de substância existente na unidade e as 
condições do processo e de armazenamento) e a definir a sensibilidade da área circunvizinha ao empreendimento (em função do risco à população e ao meio ambiente).

Figura 14. Diagrama lógico para determinação do grau de risco de um processo industrial (seg. MAKARON, 1992)

\begin{tabular}{|c|c|c|c|c|}
\hline \multicolumn{2}{|c|}{$M^{3} / M_{\text {of }}>1 ?$} & \multicolumn{2}{|c|}{$M^{\prime} / M_{c f}>0.1 ?$ Área sensivel? } & Grau de Risco \\
\hline & sim & $\downarrow$ & & I (alto) \\
\hline & & & $\operatorname{sim}$ & I (alto) \\
\hline \multirow[t]{6}{*}{ Atividade $\mathrm{x}$} & & sim & & \\
\hline & & & não & II (médio) \\
\hline & não & & & \\
\hline & & & sim & II (médio) \\
\hline & & não & & \\
\hline & & & não & III (baixo) \\
\hline
\end{tabular}

Esse último item, que é proposto para avaliar a sensibilidade de uma área próxima a um determinado empreendimento considera o risco I população e meio ambiente definido como sendo relativo a: densidade populacional, áreas industriais, serviços públicos, e sistemas viários e aeroportos. Esse critério não leva em conta vários outros parâmetros ambientais (sócioeconômicos e/ou biogeofísicos) que são relevantes para a classificação da área quanto à sua sensibilidade.

Embora o método para a classificação preliminar de risco de uma atividade deva ser rápido e de fácil elaboração, isto não deve implicar no desconhecimento de aspectos que poderão influir na decisão gerencial de fazer, ou não, um estudo mais profundo dos riscos presentes. Para tanto, outros aspectos devem ser observados durante a realização da classificação de risco. Esses aspectos devem necessariamente incluir os parâmetros relativos aos recursos naturais, ecossistemas, aspectos históricos e geológicos, além de ampliar os aspectos sociais já existentes.

Evidentemente, os dados a serem coletados para se elaborar a classificação proposta não devem se transformar em inquérito complexo como o existente no estudo de impacto ambiental (EIA). Nesse caso, o que se propõe é uma identificação simples das áreas sensíveis, através de respostas fechadas do tipo "sim/não", que permitam ao gerenciador do processo de análise a certeza que os aspectos relativos a meio ambiente foram adequadamente abordados.

\subsubsection{Proposta de aprimoramento na metodologia CATBRAS}

A técnica existente considera a presença urbana e serviços públicos, além do risco provocado por empresa vizinha, que também possua um risco alto com relação às substâncias presentes. Essas considerações, que levam em conta os aspectos sócio-econômicos, não requerem modificações.

Entretanto, como a técnica não considera os aspectos ecológicos e os recursos naturais que poderiam ser atingidos por um acidente maior, propõe-se que durante a realização da análise sejam incluidos os seguintes aspectos (CANTER, 1991; ABSY et al, 1995):

- Delimitação da área de influência direta de um acidente maior, baseando-se na abrangência dos recursos naturais diretamente afetados pelo evento. As distâncias estabelecidas anteriormente, com um raio de $5 \mathrm{~km}$, devem ser adotadas, a fim de abranger possibilidades de vazamentos líquidos e gasosos.

- $\mathrm{Na}$ área de influência definida anteriormente, devem ser identificadas (CANTER, 1991) uma ou mais das seguintes áreas: 
a. lagos e represas direta ou indiretamente ligados às redes de drenagem do empreendimento (considerando que o vazamento de um produto qualquer possa atingir esse recurso, mesmo que existam procedimentos para ações emergenciais);

b. mangues, praias protegidas ou abertas, costões, estuários;

c. rios, riachos ou outras águas superficiais de porte, protegidas pela legislação federal ou estadual;

d. água subterrânea que possa ser usada para consumo humano, irrigação ou dessedentação de animais;

e. área de proteção ambiental;

f. área com vegetação nativa ou exótica;

g. presença de animais silvestres;

h. presença de monumentos históricos ou sítios arqueológicos;

i. área e cultivo e de produção comercial;

j. solo desprotegido.

A identificação das fontes de risco considera as possiveis operações que gerariam contaminações ambientais e identifica claramente os produtos perigosos que poderiam causar um acidente com efeitos ambientais.

Complementada com uma análise dos aspectos ambientais, mesmo que não se trate de avaliação estruturada, pode evidentemente auxiliar na identificação do que está potencialmente sob risco e quais recursos ecológicos devem ser protegidos, considerando possiveis necessidades futuras de recuperação ou remediação de áreas comprometidas em um evento não desejado.

Nesta etapa de identificação do risco apresentado por uma atividade industrial, de gerar efeitos adversos ao meio ambiente, propõe-se que o gerenciador do processo de análise de risco considere a área vizinha ao seu empreendimento, reconhecendo o valor ecológico existente e prevenindo futuras contingências ambientais.

Para facilitar sua aplicação e adequação aos moldes existentes para a análise do risco de armazenamento e processo, os aspectos relativos a meio ambiente também devem sofrer uma classificação preliminar. Assim, propõe-se, neste trabalho, que cada um dos meios físicos - ar, água e solo - possa ser estudado estimando-se os efeitos possíveis a partir de elementos provenientes da realização de um acidente. Para cada elemento, é proposta uma graduação de risco, variando de 1 a 3 , conforme o dano esperado, se não houver controle sobre sua efetivação.

$\mathrm{Na}$ tabela 19 estão descritos os itens que compõem a graduação proposta. Nela, os meios solo, ar e água incorporam as seguintes condições:

ar - emissão de substância perigosa, formando nuvem densa ou não;

solo - disposição acidental ou planejada de líquidos, sólidos e semiliquidos classificados como perigosos, em solo sem impermeabilização;

água - refere-se a vazamentos de líquidos perigosos que possam atingir os corpos receptores em geral (rios, lagos, represas, estuários, águas de áreas de manguezais, região costeira, águas subterrâneas).

O item controle existente considera a existência, ou não, de controles instalados para atuação imediata em caso de efetivação de um vazamento. A tabela 19 contém, ainda, o item condiçăo existente, que relata quais são as condições presentes que levarão à classificação do risco e, finalmente, o item classe de risco, que permite elencar em que categoria o meio avaliado estará enquadrado, na efetivação de um dado acidente.

Os dados apresentados na tabela 19, associados à classificação do processo industrial, permitem obter a classificação final de uma operação ou atividade através da aplicação de uma árvore decisória que considera cada uma das etapas percorridas e os resultados nelas obtidos, relativos à sensibilidade da área, processo, armazenamento e quantidade de substâncias presentes (Fig. 15). 
Tabela 19. Proposta de graduaçáo dos riscos relativos à sensibilidade da área circunvizinha a um empreendimento

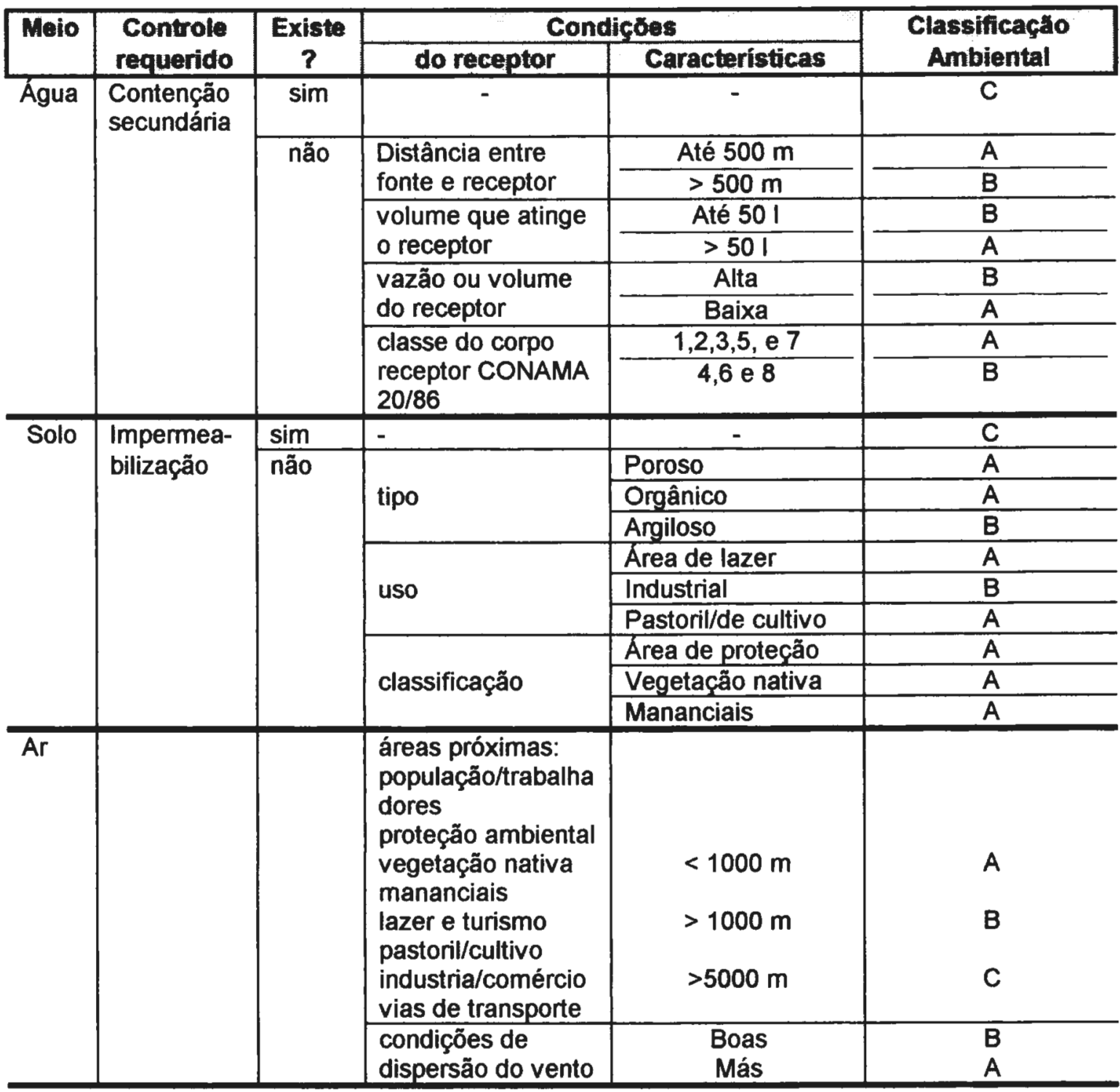

A aplicação da árvore proposta deve considerar, portanto, os conceitos existentes na CATBRAS e as modificações feitas, conforme descrito:

a) relação Massa corrigida ( $\left.M^{\prime}\right) /$ Massa Crítica Final $\left(M_{c f}\right)$ configurando o potencial de risco $\left(M^{\prime} / M_{\mathrm{cf}} \geq 1\right.$ : alto potencial de risco, e $M^{\prime} / M_{\mathrm{cf}}>0,1$ : médio potencial de risco);

b) a sensibilidade da área, item modificado por este trabalho para melhor definir os meios afetados e os eventuais danos;

c) a existência ou não de equipamentos ou procedimentos para evitar que um determinado vazamento, ondas de calor ou choque, derrame, ou outro evento possa atingir o meio considerado, item proposto por este trabalho;

d) a classe de risco em que um determinado evento é enquadrado, utilizando o mesmo critério da CATBRAS.

A proposta seria acrescida à CATBRAS, quando esta avalia a sensibilidade da área vizinha, não alterando os conceitos pré-existentes. A avaliação final que fornece a "classe de risco do processo e do armazenamento" não sofreria nenhuma modificação, podendo ser usados os mesmos termos aplicados para avaliar os possiveis riscos ambientais. 
Figura 15. Classificaçăo dos riscos através da análise do processo industrial, armazenamento de substâncias perigosas e a sensibilidade ambiental da área circunvizinha

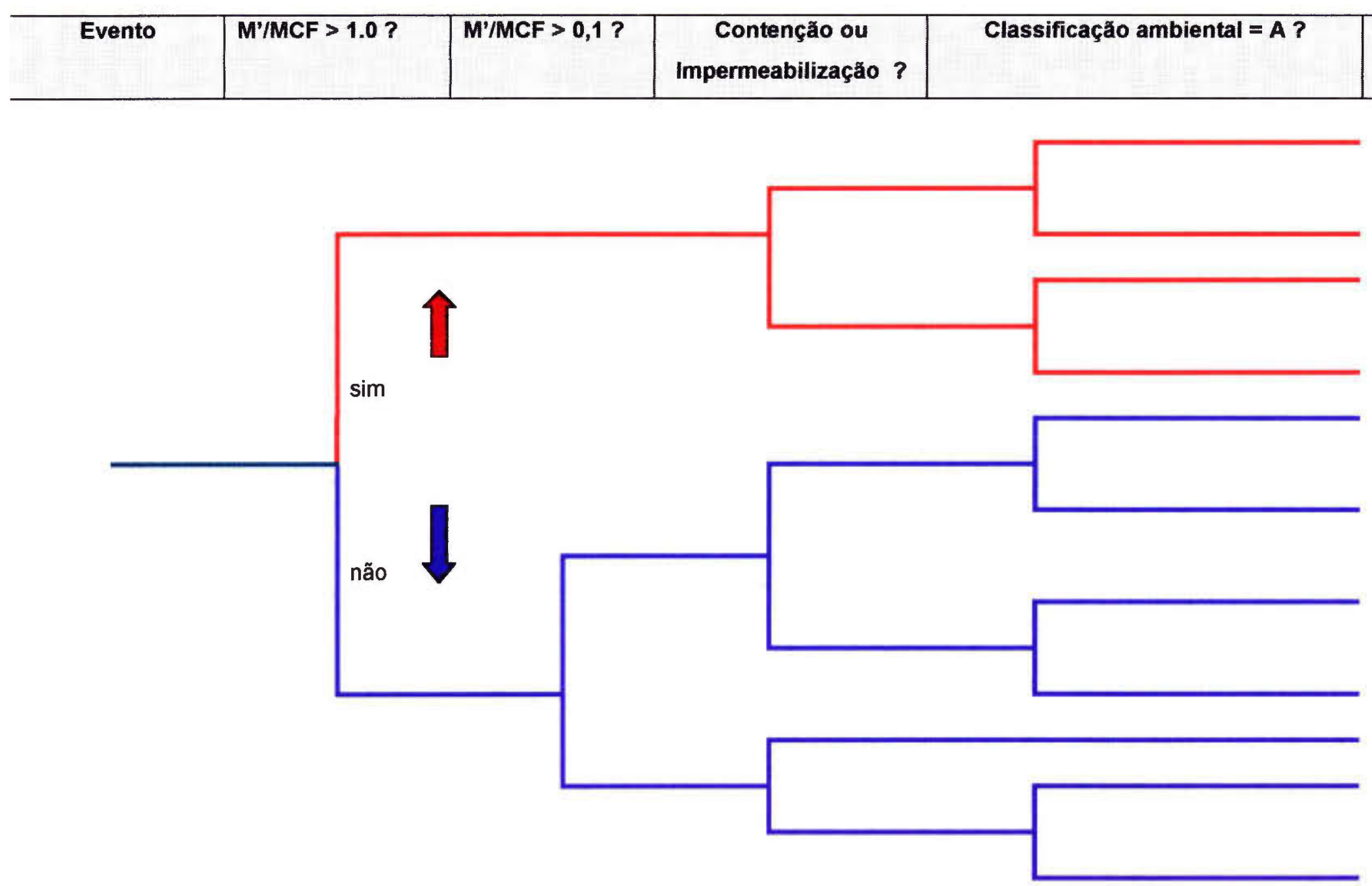

Classe final

de risco

B

C

A

B

B

C

A

B

C

B 


\subsubsection{Definição das hipóteses de acidentes}

Aqueles processos que na identificação do grau de risco não apresentam classes de risco altas, certamente serão preteridos no momento de decisão de fazer ou não a análise de risco. Entretanto, essa classificação pode não refletir a realidade da extensão do risco identificado. Para os processos que apresentam algum risco identificado, é imperativa a realização de, no mínimo, uma Análise Preliminar de Riscos, quando serão identificados os riscos presentes e propostas medidas para eliminá-los ou minimizá-los. Como citado na descrição das técnicas de análise de risco, a APR se presta a identificar o risco, a causa do risco, e também os efeitos da eventualidade de realização do evento crítico. A técnica foi originalmente criada para identificar $e$ propor controles dos riscos referentes a danos funcionais e à saúde humana, e definir uma prioridade de controle a partir da classificação dos riscos identificados.

O propósito da APR elaborada pelos militares americanos nos programas de segurança é a identificação antecipada dos riscos e medidas preventivas de qualquer processo ou atividade, produto ou sistema, na fase de projeto ou em operação. À medida que o risco é identificado, são também arroladas as causas em potencial, os efeitos e a gravidade dos acidentes previstos, bem como as possíveis medidas corretivas e/ou preventivas (FANTAZZINI \& FARBER, 1989).

A gravidade dos acidentes previstos é usada para propiciar a classificação do risco identificado. $\mathrm{Na}$ versão original dessa ordenação, é feita a avaliação do grau de impacto da realização do evento sobre a saúde humana ou sobre o processo, atividade, sistema e outras perdas patrimoniais. Na tabela 20 são apresentados os termos comuns para avaliação do impacto negativo do evento na versão original. Nessa tabela, há uma ordenação dos efeitos, considerando a falha do processo ou atividade e os danos ou degradação funcionais ou lesōes. Também levase em conta a possibilidade de ação corretiva e perdas. Evidentemente, quanto maior o dano ou a perda, mais severa é a classificação do risco.

$\mathrm{Na}$ classificação original, usada para segurança do trabalho, aspectos ocupacionais, processos e operações, além das substâncias químicas, os termos aplicados são:

- danos ao sistema

- danos funcionais

- lesões/mortes

Freqüentemente, os técnicos encarregados de aplicar a técnica são oriundos das áreas de engenharia, produção e segurança, o que implica no conhecimento das operações da unidade e de uma linguagem típica dessa área. Esse conhecimento facilita a identificação do risco e principalmente a classificação dos efeitos esperados.

O "dano ao sistema" pode ser facilmente subdividido, e uma graduação pode ser atribuída a essa subdivisão. A partir do conhecimento do "sistema" e de sua operação, um setor, processo, operação, máquina, tanque, pode ser graduado em: desde totalmente perdido, até simplesmente paralisado (fora de uso) por algumas horas. O mesmo ocorre com os "danos funcionais", que se referem ao funcionamento ou operação de um sistema. Nesse caso, a graduação vai desde: paralisação prolongada para troca de peças ou equipamentos não disponiveis em estoques intemos ou prateleiras comerciais, até simples troca de peças ou equipamentos que demandem apenas algumas horas.

Em relação ao dano do trabalhador, a graduação dada a lesões e até morte, segue a orientação do departamento médico da empresa.

\subsubsection{Metodologia}

FANTAZZINI \& FARBER (1989) propõem a adequação da APR, para uma APR com riscos ambientais. Nessa proposta, a técnica "contempla os principais riscos potenciais de comprometimento ambiental que as instalações, substâncias, processos e operações associadas venham a oferecer, não se preocupando, necessariamente, com aspectos ocupacionais e de segurança do trabalho". 
As categorias de riscos propostas foram adaptadas pelos autores citados baseando-se nos termos empregados pela norma militar americana MIL-STD-882A. As categorias de riscos ambientais propostas no trabalho estão na tabela 20 , incorporando somente a expressão impacto ambiental quando da avaliação da gravidade dos acidentes previstos. Foram mantidas as mesmas graduações, considerando o impacto ambiental como danos substanciais e danos severos, compensáveis ou não, e danos inaceitáveis.

A simples ordenação dos efeitos de um acidente sobre o meio ambiente, através das expressões substanciais, severos e inaceitáveis, não permite ao técnico responsável para elaborar a APR-A diferenciar entre uma classe e outra, a não ser que ocorram fatalidades. Quando comparada com a versão original, a expressão danos substanciais ao sistema inclui uma graduação que se refere à paralisação do sistema e perda de produção, enquanto que severa degradação do sistema se refere à perda total do mesmo. Dessa maneira, o entendimento e graduação de um efeito sobre o sistema ou atividade podem ser feitos a partir de conceitos existentes entre os operadores de uma unidade.

Evidentemente, essa condição de conhecimento/treinamento e facilidade de graduação não vale quando se trata de aspectos ambientais, exigindo do técnico alguma experiência nas questões relativas a controle e proteção ambientais.

\subsubsection{Análise da metodologia da APR}

Apesar de sua real utilidade e facilidade de aplicação, a técnica proposta por FANTAZZINI \& FARBER (1989) deve ser aprimorada, para ser melhor aproveitada como uma técnica alternativa para os riscos considerados e que requerem técnicas simples de identificação. Evidentemente, esse aprimoramento vai exigir dos técnicos que irão aplicar a APR ambiental conhecimentos da área ambiental e que não estão definidos no trabalho proposto pelos autores citados. Esse novo requisito poderia impossibilitar (ou inibir) sua aplicação de forma ampla.

Considerando que a APR é, sem dúvida, uma boa técnica, propõe-se, a seguir, uma evolução da metodologia, de forma que possa ser aplicada a um processo siderúrgico.

\subsubsection{Proposta de aprimoramento da Avaliação Preliminar de Risco - Ambiental (APR-A)}

Para melhor entender a proposta de aprimoramento da APR-A, serão feitas inicialmente algumas considerações de ordem prática, envolvendo conceitos, definições e graduações de danos observados e esperados.

Impacto ambiental, segundo a Resolução CONAMA 01, de 23 de janeiro de 1986 (CONAMA, 1986a), é "qualquer alteração das propriedades físicas, químicas e biológicas do meio ambiente, causada por qualquer forma de matéria ou energia resultante das atividades humanas que, direta ou indiretamente, afetam:

I - a saúde, a segurança e o bem-estar da população;

II - as atividades sociais e econômicas;

III - a biota;

IV - as condições estéticas e sanitárias do meio ambiente;

$V$ - a qualidade dos recursos ambientais".

Dano é a severidade da lesão, ou da perda física, funcional ou econômica, incluindo também o impacto ambiental, se é perdido o controle sobre um risco (LEES, 1980).

Risco é conceituado, segundo WHYTE \& BURTON (1980), como sinônimo de perigo, isto é, algo que possui potencial para causar um dano, ou ser entendido como tendo a probabilidade (matemática) de causar um acidente/incidente. 
Tabela 20. Categorias de riscos, conforme proposto por FANTAZZINI \& FARBER (1989)

\begin{tabular}{|c|c|c|}
\hline Categoria & Versão original (MIL-STD-882A) & Proposta ambiental \\
\hline I-Desprezível & $\begin{array}{l}\text { A falha não irá resultar numa degradação maior do } \\
\text { sistema, nem irá produzir danos funcionais ou lesões, ou } \\
\text { contribuir com um risco ao sistema }\end{array}$ & O risco não irá resultar em impacto ambiental \\
\hline II - Marginal ou limítrofe & $\begin{array}{l}\text { A falha irá degradar o sistema numa certa extensão, porém } \\
\text { sem envolver danos maiores ou lesões, podendo ser } \\
\text { compensada ou controlada adequadamente }\end{array}$ & $\begin{array}{l}\text { O risco poderá resultar em impacto ambiental, com danos } \\
\text { de certa extensão, podendo ser compensado ou controlado } \\
\text { adequadamente }\end{array}$ \\
\hline IV - Catastrófica & $\begin{array}{l}\text { A falha irá produzir severa degradação do sistema, } \\
\text { resultando em sua perda total, lesões ou mortes }\end{array}$ & $\begin{array}{l}\text { O risco poderá resultar em impacto ambiental com severos } \\
\text { danos, incluindo fatalidades }\end{array}$ \\
\hline
\end{tabular}


Acidentes são freqüentemente conceituados como a liberaçăo súbita e de maneira inesperada de produtos perigosos em quantidade igual ou superior ao necessário para causar danos relativos (materiais, humanos e ambientais) (LEES, 1980).

Incidentes são conceituados como o dano que poderia ter ocorrido se um risco viesse a acontecer com consequências negativas.

Causa de um risco é conceituada como a origem provocadora do acidente/incidente que resulta na realização de um risco.

Efeito é a materialização de um risco (acidente/incidente) com danos patrimoniais, à saúde humana ou ao meio ambiente.

Categoria ou grau de risco é a definição de uma ordem de grandeza, relacionada à probabilidade de ocorrência e intensidade de possiveis impactos e danos à propriedade, à saúde humana e ao meio ambiente.

O aprimoramento proposto para a APR, já modificada por FANTAZZINI \& FARBER (1989), refere-se a um melhor entendimento dos critérios para "classificação dos riscos", considerando os efeitos ambientais previstos.

O grau de risco, ou a "categoria de risco" de um evento, é obtido, segundo a MIL-STD-882A, a partir da avaliação dos danos/impactos sobre a saúde humana e/ou patrimônio e processo resultante da efetivação de um acidente/incidente.

A análise dessa premissa para sua aplicação aos efeitos ambientais deve estar fundamentada nos termos dano/ impacto e acidente/ incidente.

Os termos acidente/incidente devem ser levados em conta na identificação do risco ambiental, para que possa haver uma clara diferença entre poluição - risco de dano/impacto ao meio ambiente, por exposição continua e controlada, podendo ser legal ou não, e acidente - liberação súbita e de maneira inesperada de produtos perigosos que causam danos ao meio ambiente. Evidentemente, na proposta deste trabalho é considerado o acidente ou a efetivação de um evento identificado.

Os termos dano e impacto têm conotações que auxiliam na obtenção do grau de risco envolvendo os aspectos ambientais.

O termo impacto associado ao meio ambiente permite determinar se o que está no meio ambiente pode sofrer alteração das suas propriedades físicas, químicas e biológicas, definindo melhor o que está sendo considerado quando se menciona a expressão impacto ambiental. Assim sendo, o técnico responsável pela aplicação da APR-A deve conhecer os meios que direta ou indiretamente poderão estar expostos se houver a efetivação de um acidente. As alterações citadas poderão ser sentidas ou afetar: I - a saúde e segurança da população que reside e/ou transita na área de influência da empresa; II - as atividades sociais (patrimônios históricos, públicos, locais preservados, etc.) e econômicas (áreas cultivadas, restrição de acessos, comércio, etc.); III - os ecossistemas característicos da região da empresa; e IV - a qualidade dos recursos ambientais, caracterizados como aqueles recursos disponíveis e explorados de forma correta pela comunidade. Já o dano, entendido como a severidade do impacto, isto é, a gravidade da alteração provocada num determinado meio, permite obter uma ordem de grandeza relacionada à intensidade ou severidade do impacto.

A associação dos termos impacto ambiental e dano levam, portanto, à obtenção do grau de risco de um evento.

A elaboração da APR-A, a partir da técnica proposta pela MIL-STD-882A e incorporação dos conceitos adotados neste trabalho, deve ter o seguinte desenvolvimento: 


\section{$1^{2}$ etapa: identificação do risco (ambiental, saúde humana, processo, patrimonial)}

Esta etapa não deve sofrer alteração, devendo ser realizada conforme proposta da MIL-STD882A. A identificação do risco é um processo que envolve verificar quais são os eventos que podem ocorrer em um processo ou atividade, não importando os efeitos futuros, ambientais ou não. Freqüentemente, esta etapa é cumprida a partir de dados históricos de acidentes ocorridos em operações/atividades semelhantes ou experiência profissional. Nesse caso, são relacionados inicialmente todos os riscos já identificados e, a partir daí, inicia-se a análise de risco.

\section{$2^{2}$ etapa: determinação da causa dos riscos identificados}

Cada risco identificado deve ser analisado a fim de determinar a causa principal de sua existência. Nesta atividade, não há necessidade de uma análise profunda através do levantamento das causas intermediárias, bastando ao técnico ter informações confiáveis sobre as possiveis causas de ocorrência do risco identificado.

\section{$3^{2}$ etapa: determinaçáo dos efeitos da realização do acidente}

Para a determinação dos efeitos sobre a saúde humana, o patrimônio e/ou processo, deve-se seguir a técnica original MIL-STD-882A. Neste caso, é fundamental a experiência dos operadores dos sistemas e do técnico responsável pela elaboração da APR-A.

\section{$4^{2}$ etapa: determinação da classe dos riscos identificados}

A graduação dos riscos deve seguir os conceitos propostos no procedimento original. A caracterização dos impactos ao meio ambiente, que, em síntese, é o objetivo desta proposta, deve ser feita a partir dos conceitos de impacto e severidade do dano esperado.

Tomando-se por base a definição dada pela Resolução CONAMA no 01/86 (CONAMA, 1986a) para impacto ambiental e os meios que podem ser afetados, e o conceito de dano proposto por LEES (1980), elaborou-se uma tabela que relaciona os dois conceitos, de forma a facilitar a graduação dos riscos de acidentes.

Na tabela proposta, são apresentados o meio que pode ser afetado, segundo a Resolução CONAMA citada, e os elementos que compõem esse meio. Os exemplos dados como elementos constituintes do meio não são definitivos, devendo ser complementados sempre que possivel. Neste trabalho, os meios serão agrupados, conforme proposto a seguir:

- saúde/bem-estar da população

- segurança da população

patrimônio

- atividades sociais

sistemas de transporte

sistemas de comunicação

áreas de recreação

escolas

templos religiosos

praças públicas

aspectos estéticos

sitios históricos

sítios arqueológicos

sítios espeleológicos

turismo

- atividades econômicas

fontes de energia

áreas cultivadas (agricultura, pastagens)

suprimentos de água

pesca

uso e ocupação do solo

- biota 
fauna (crustáceos, insetos, aves, répteis, mamíferos, peixes, etc.);

flora (algas, gramíneas, arbustos, árvores, etc.);

microorganismos (bactérias, fungos, protozoários, etc.)

- qualidade dos recursos naturais

água (rios, lagos, represas, regiões estuarinas e costeiras, aqüiferos subterrâneos);

solo (florestas, matas, mangues, alagados, recursos minerais, paisagens);

ar

A magnitude e intensidade dos danos deverão ser avaliadas pelos técnicos responsáveis pela elaboração da APR-A, a partir do conhecimento das características e quantidades das substâncias que poderão ser liberadas num acidente. Neste trabalho, os danos ambientais serão agrupados de acordo com o efeito sobre o meio, conforme proposto a seguir (Tab. 21):

- lesões (leves, médias, graves)

- morte

- danos

leves (reversivel, reparável, temporário, pequena extensão);

substanciais (reversivel, reparável, temporário, grande extensão);

severos (irreversivel, irreparável, permanente, independe da extensão).

- perdas (leves, médias, graves)

A partir da graduação feita, é então proposta uma terminologia para grupos que apresentam afinidades relativas ao efeito percebido.

Consolidando os conceitos de impacto ao meio ambiente, de graduação dos efeitos desse impacto aos vários meios definidos e da terminologia mais apropriada para cada efeito, é possível organizar todas as informações colhidas até o momento e adaptar as categorias de risco de APR da MIL-STD-882A e a proposta de FANTAZZINI \& FARBER (1989) para que possam ser aplicadas à análise de risco ambiental.

Tabela 21. Proposta de adequação de terminologia e graduação do risco ambiental

\begin{tabular}{|c|c|c|c|}
\hline \multirow[t]{2}{*}{ Meio afetado } & \multicolumn{2}{|c|}{ Efeitos } & \multirow{2}{*}{$\begin{array}{c}\text { Classe de } \\
\text { risco }\end{array}$} \\
\hline & Termo & Grau & \\
\hline Saúde e bem-estar da população & Lesões & $\begin{array}{l}\text { leve } \\
\text { médio } \\
\text { grave } \\
\text { morte }\end{array}$ & $\begin{array}{l}\text { II } \\
\text { III } \\
\text { IV } \\
\text { IV }\end{array}$ \\
\hline $\begin{array}{l}\text { Segurança da população } \\
\text { Atividades sociais } \\
\text { Atividades econômicas }\end{array}$ & Perdas & $\begin{array}{l}\text { leve } \\
\text { médio } \\
\text { grave } \\
\text { total }\end{array}$ & $\begin{array}{l}\text { II } \\
\text { III } \\
\text { IV } \\
\text { IV }\end{array}$ \\
\hline $\begin{array}{l}\text { Biota } \\
\text { Qualidade dos recursos }\end{array}$ & Danos & $\begin{array}{l}\text { leve } \\
\text { substancial } \\
\text { severo }\end{array}$ & $\begin{array}{l}\text { II } \\
\text { III } \\
\text { IV }\end{array}$ \\
\hline
\end{tabular}

Na tabela 22 é apresentada a versão proposta por FANTAZZINI \& FARBER (1989) para a classificação dos riscos ambientais, e a proposição deste trabalho para a mesma ordenação, a partir da consolidação dos conceitos adotados.

O modelo apresentado mostra, de forma simplificada, a identificação dos efeitos possíveis se houver a materialização de um risco. $A$ inclusão dos aspectos ambientais diretamente na versão original da técnica, aliada à indicação, de forma direta ou induzida, do meio que está sendo avaliado, do potencial de dano de uma substância e a importância ecológica e econômica do meio avaliado, tornam a aplicação da técnica mais simples, requerendo do técnico somente o conhecimento da área de influência da fábrica ou processo, a periculosidade das substâncias envolvidas e as vias de atingimento da área externa da unidade. A planilha elaborada traz os meios que o aplicador da técnica deve considerar, a terminologia a ser adotada e uma 
categorização dos efeitos, a fim de permitir identificar a classe de risco que o acidente poderá produzir.

\subsubsection{Avaliação das conseqüências das hipóteses de acidentes definidas}

Como já discutido anteriormente, a Árvore de Eventos (AE) avalia o potencial de ocorrer um determinado acidente resultante de uma falha de equipamento ou erro humano, reconhecido como evento iniciante ou causador. A técnica parte, portanto, do princípio de que um evento negativo já identificado possa ocorrer e procura prever as seqüências de eventos seguintes, através do sucesso ou de falha dos sistemas de segurança existentes.

Apresenta-se como um excelente exercicio no estudo das seqüências de falhas e sucessos de um evento, permitindo ao técnico identificar os riscos de acidentes com consequências desastrosas, podendo antecipar ações e mecanismos de controle e segurança. Sua aplicação em eventos já identificados e que possam resultar em vários eventos é muito útil, permitindo, quando necessário, quantificar o potencial do evento inicial. A sua quantificação é possivel desde que sejam conhecidas as probabilidades de seqüência dos eventos subsequentes.

\subsubsection{Metodologia}

O procedimento geral para a elaboração da AE, segundo CCPS (1985), envolve quatro etapas:

1. identificação do evento causador de interesse;

2. identificação dos sistemas de segurança previstos para o evento de interesse;

3. construir a AE;

4. descrição das conseqüências do evento base.

Estas etapas foram definidas considerando a análise de risco de um processo ou a sua operação, sem envolver a variável ambiental. Entretanto, os conceitos são coincidentes em alguns dos itens propostos, ou necessitam de modificações substanciais.

A etapa 1, como proposto pelo CCPS (1985), prevê a identificação do evento base ou causador do acidente, e considera que o evento deva ser a falha de um processo, um erro humano que possa resultar numa série de eventos subsequentes. Se o evento base resultar em um acidente específico, o CCPS (1985) não recomenda o emprego da AE.

A etapa 2, determinada pelo CCPS (1985) prevê a descrição dos sistemas de segurança que existem, ou deverão existir, para prevenir o evento base identificado. $\mathrm{Na}$ análise de risco de segurança, estes itens envolvem, principalmente:

- sistemas de segurança que atuam automaticamente

- alarmes (sonoros ou visuais)

- respostas operacionais previstas em caso de falhas

- barreiras ou outros métodos de contenção previstos para limitar os efeitos do evento base

O técnico encarregado de elaborar a $A E$ deve identificar previamente todas as funções que podem alterar o rumo de desenvolvimento do evento base, e considerar, além disso, a ordem cronológica dos eventos intermediários que possam ocorrer em função dos sistemas de controle e prevenção existentes.

$\mathrm{Na}$ etapa 3 está prevista a elaboração da AE. Da mesma forma que se elabora um fluxograma de uma atividade qualquer, pode-se elaborar a $A E$. O primeiro passo é identificar o evento base e as funções de segurança previstas. Na margem esquerda da planilha, é identificado o evento base, os sistemas ou funções de segurança são dispostos ao longo da planilha, em ordem cronológica de atuação, iniciando o primeiro sistema logo ao lado do evento base, e em seguida são colocados os demais sistemas ou funções.

Para cada função ou sistema de segurança previsto haverá somente duas possibilidades a serem consideradas: sucesso do sistema de segurança, isto é, o sistema funciona e o evento poderá ou 
Tabela 22. Categoria de risco ambiental, conforme proposta de aprimoramento da APR

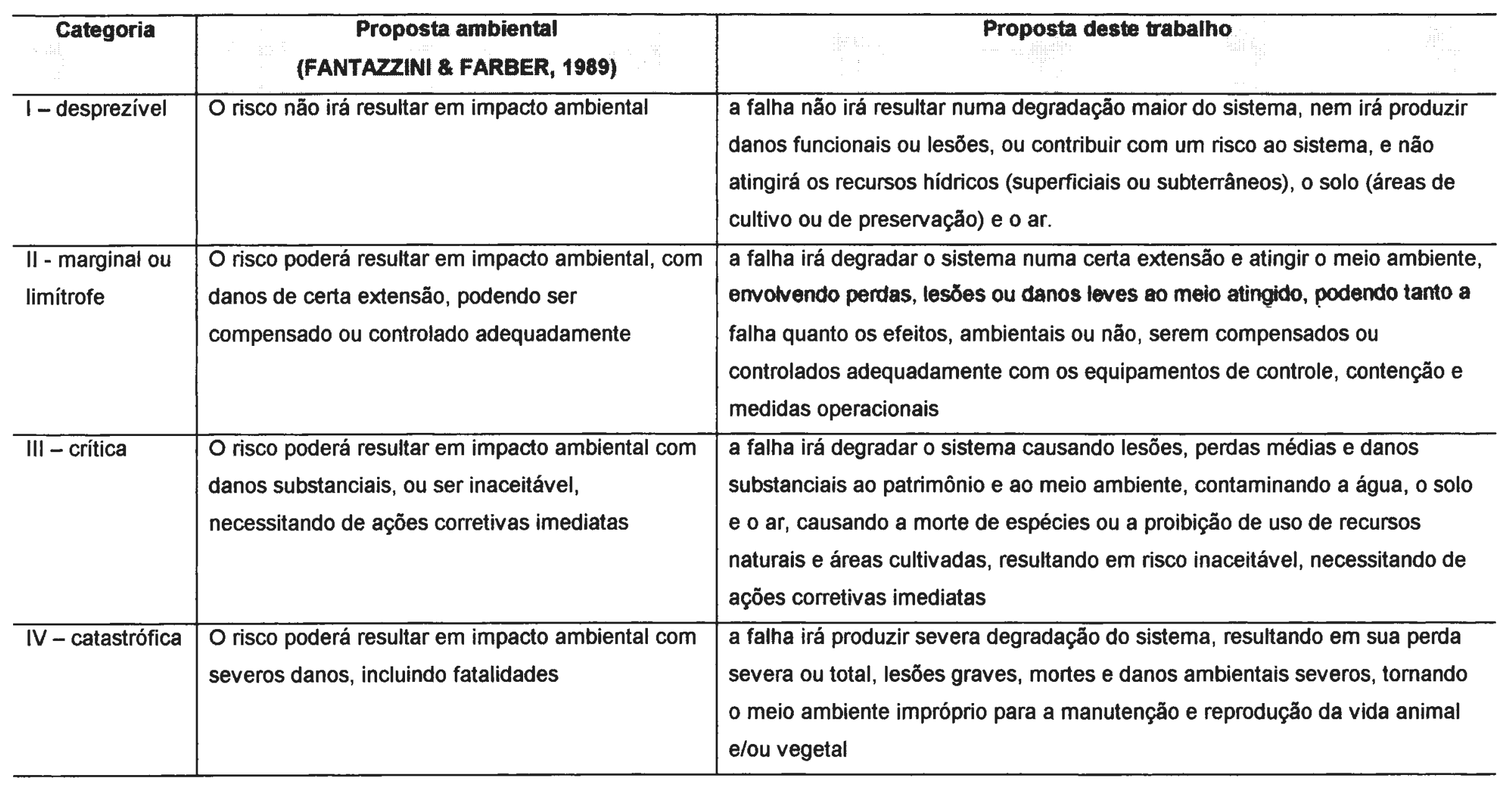


não derivar para uma segunda função de segurança, ou ocorre a falha do sistema previsto. Nesse caso, o evento deverá necessitar da próxima função de segurança. A análise se repete, para cada uma das funções ou procedimentos de segurança identificados. $O$ analista é quem deve considerar se a falha ou o sucesso de um sistema de segurança irá ou não afetar o desenvolvimento do acidente. No caso de haver alteração no desenvolvimento do acidente, o analista deve optar pela trilha de falha (dirigindo para baixo a trilha proposta) ou pelo sucesso na contenção do evento (dirigindo para cima a trilha proposta) (Fig. 17 a 19).

Se o sistema de segurança proposto não afeta o curso do acidente, a trilha continua sem ramificação, até ao próximo sistema.

Finalmente, a quarta etapa do procedimento previsto pelo CCPS (1985) é a descrição das consequências do evento. Essa conseqüência poderá representar uma variedade de problemas produzidos pelo evento base.

Para adequar a $\mathrm{AE}$ à proposta deste trabalho, os eventos considerarão os efeitos sobre o meio ambiente, de acordo com os acidentes identificados durante a elaboração da Árvore de Eventos $(A E)$.

Para entendimento da elaboração da $A E$, adotou-se os modelos propostos pelo CCPS (1985) que, numa seqüência de quatro figuras, mostra didaticamente o procedimento para elaboração de uma AE. O exemplo adotado considera a "perda de água refrigerada em um reator de oxidação", que é a etapa 1.

A etapa 2 da $A E$, adotada no exemplo, considera os seguintes sistemas de segurança, implantados no processo:

- alarme de alta temperatura (T1) no reator de oxidação;

- operador restabelece o fluxo de água refrigerada para o reator;

- sistema de parada automática atua e interrompe a reação na temperatura T2.

A figura 16 consiste na apresentação do formato da planilha que vai servir de base para a $A E$. Nela estão inseridos o evento base e as funções ou sistemas de segurança, conforme descritos anteriormente.

A figura 17 representa o início do trabalho de análise da $A E$, no qual o técnico verifica as probabilidades de sucesso ou falha no sistema de segurança previsto. $O$ processo de análise considera somente duas possibilidades: falha do sistema ou sucesso do sistema. A convenção imposta pela técnica considera a falha como processo negativo e deve seguir uma trilha com indicação para baixo do sistema analisado. Em caso de sucesso, a trilha a ser seguida será positiva, sendo representada pela trilha superior.

No exemplo dado na figura 17, o alarme de alta temperatura $T 1$ afeta o curso do evento, alertando o operador. Cada ponto de ramificação cria eventos adicionais que devem ser avaliados individualmente em cada sistema de segurança existente a seguir.

Ao avaliar uma trilha no sistema de segurança, o técnico deve considerar as condições (falha/sucesso) ditadas pela trilha do acidente até nova etapa do sistema. Na figura 18 (suposição de ocorrer o sucesso, ou seja, o alarme funcionar), a trilha superior irá requerer uma ramificação, pois o primeiro sistema teve sucesso (alarme de temperatura alta T1) e o operador pode alterar 0 curso do evento através de outro sistema. Na suposição de ocorrer a falha, deve-se seguir a trilha inferior, que não vai requerer uma ramificação, porque o alarme de alta temperatura falharia e o operador năo seria alertado dos efeitos do desenvolvimento do efeito, năo tendo, portanto, oportunidade de alterar o curso do evento. A trilha inferior (operador restabelece o fluxo de água refrigerada) levaria diretamente ao primeiro sistema de segurança existente.

O exemplo proposto pelo CCPS (1985) para avaliação dos sistemas de segurança e as possíveis ramificações do evento identificado continua na figura 19. Nessa figura, supõe-se que o caminho superior (sucesso) năo tem uma nova ramificação para a parada automática (terceiro sistema de 
Figura 16. Primeira etapa na construçăo da AE para o exemplo apresentado

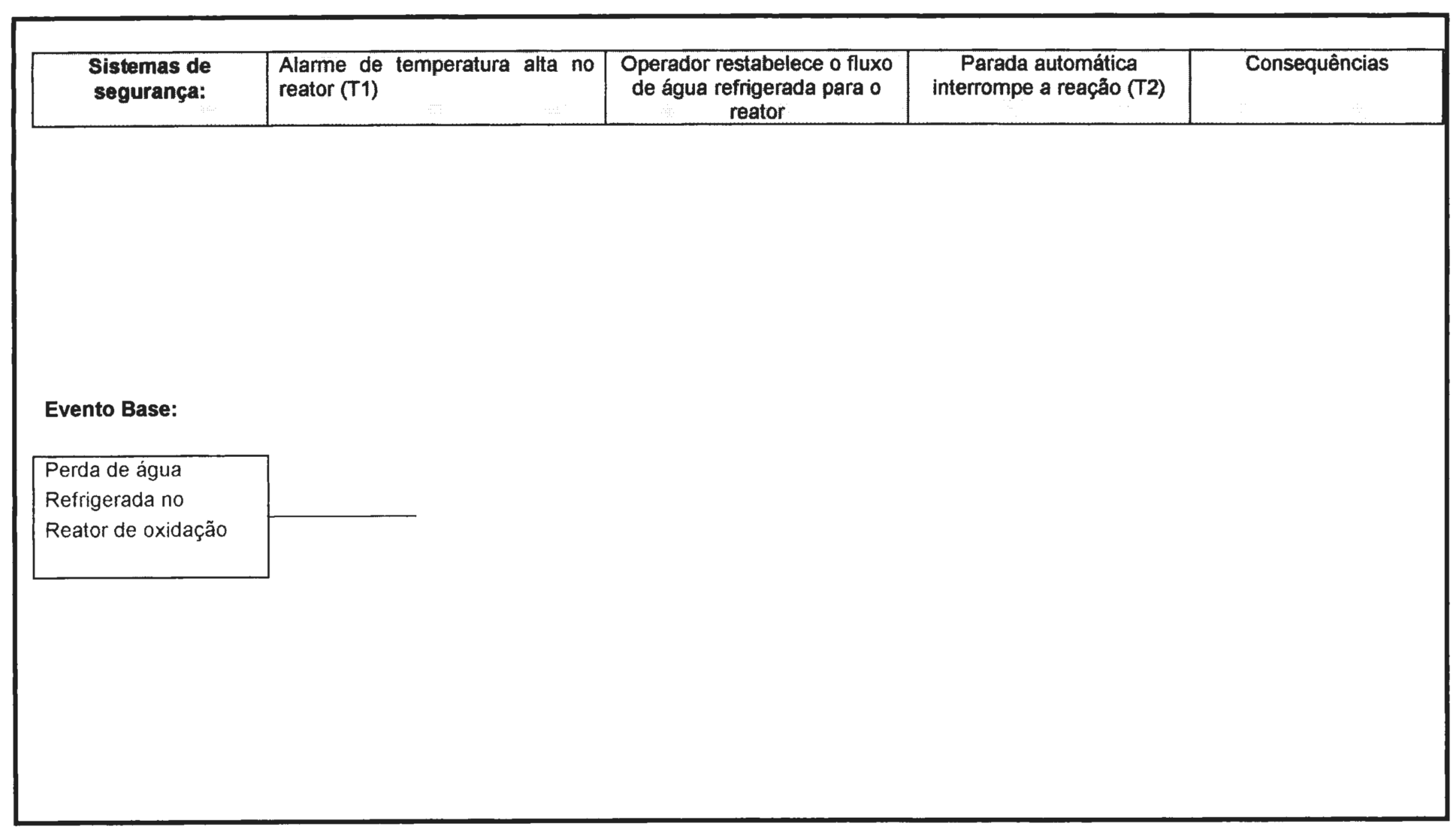


Figura 17. Representação da análise da primeira funçăo do sistema de segurança

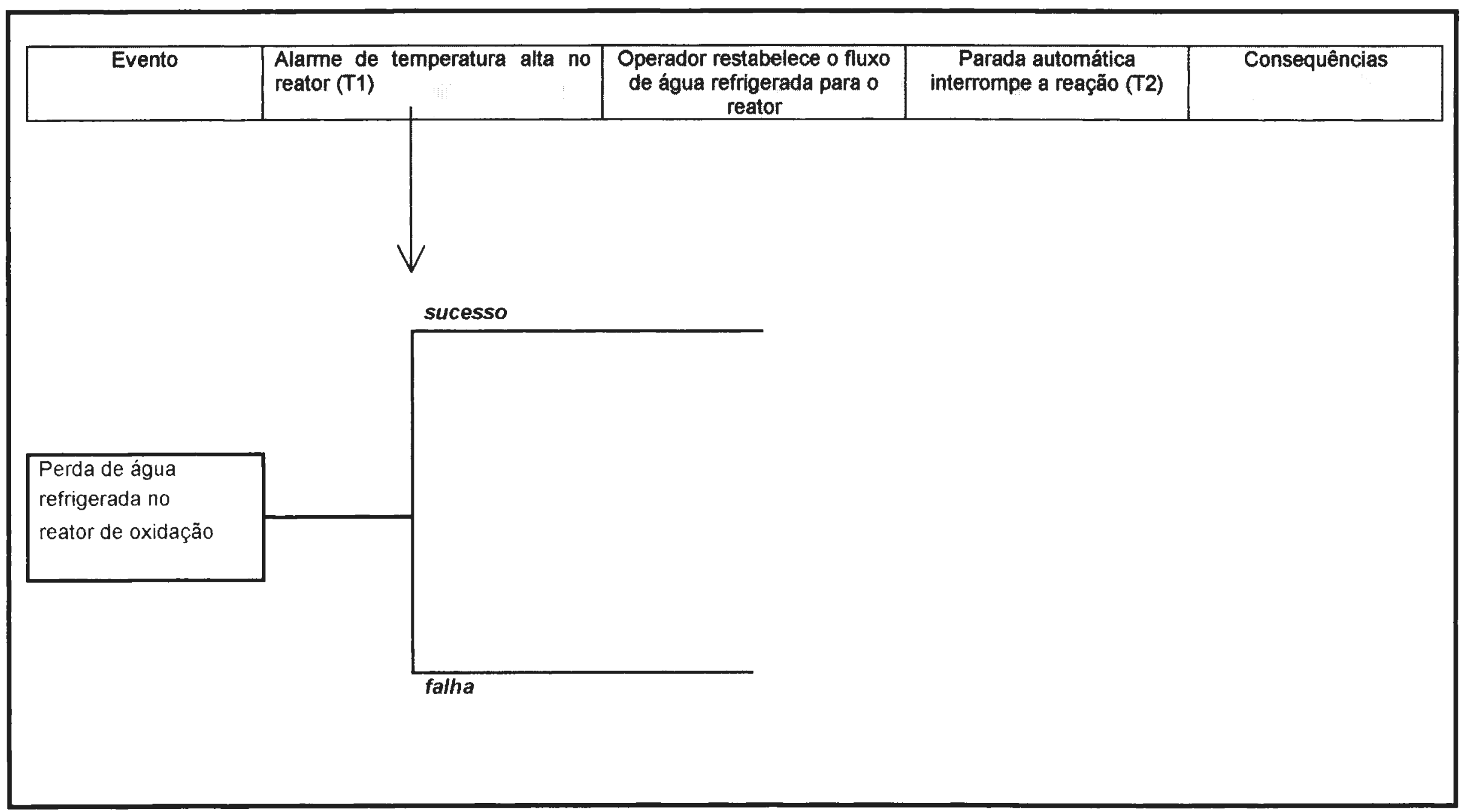


Figura 18. Representaçăo do segundo sistema de segurança

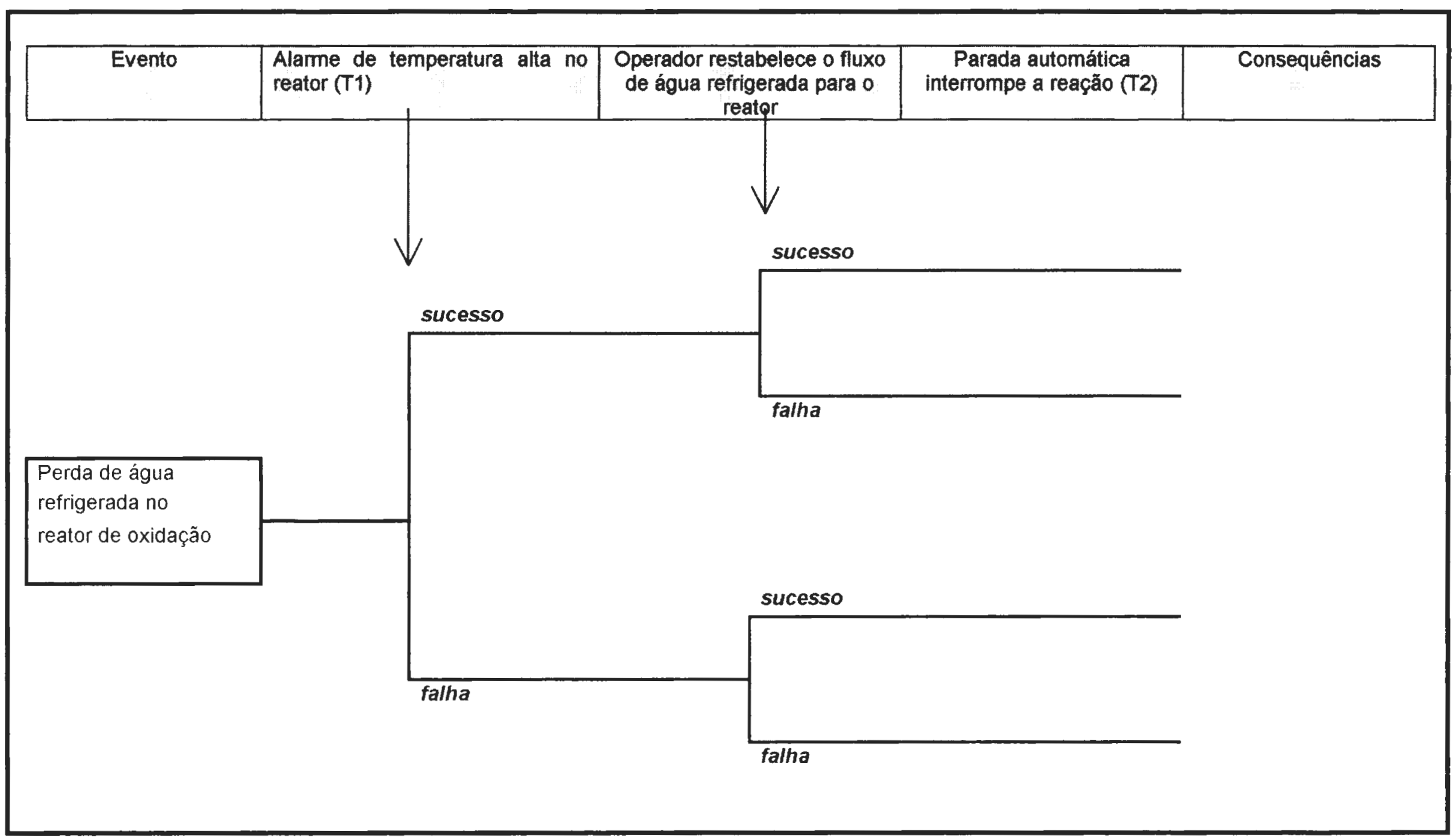


Figura 19. Árvore de Eventos (AE) completa, para avaliaçăo dos sistemas de segurança e ramificaçóes possiveis

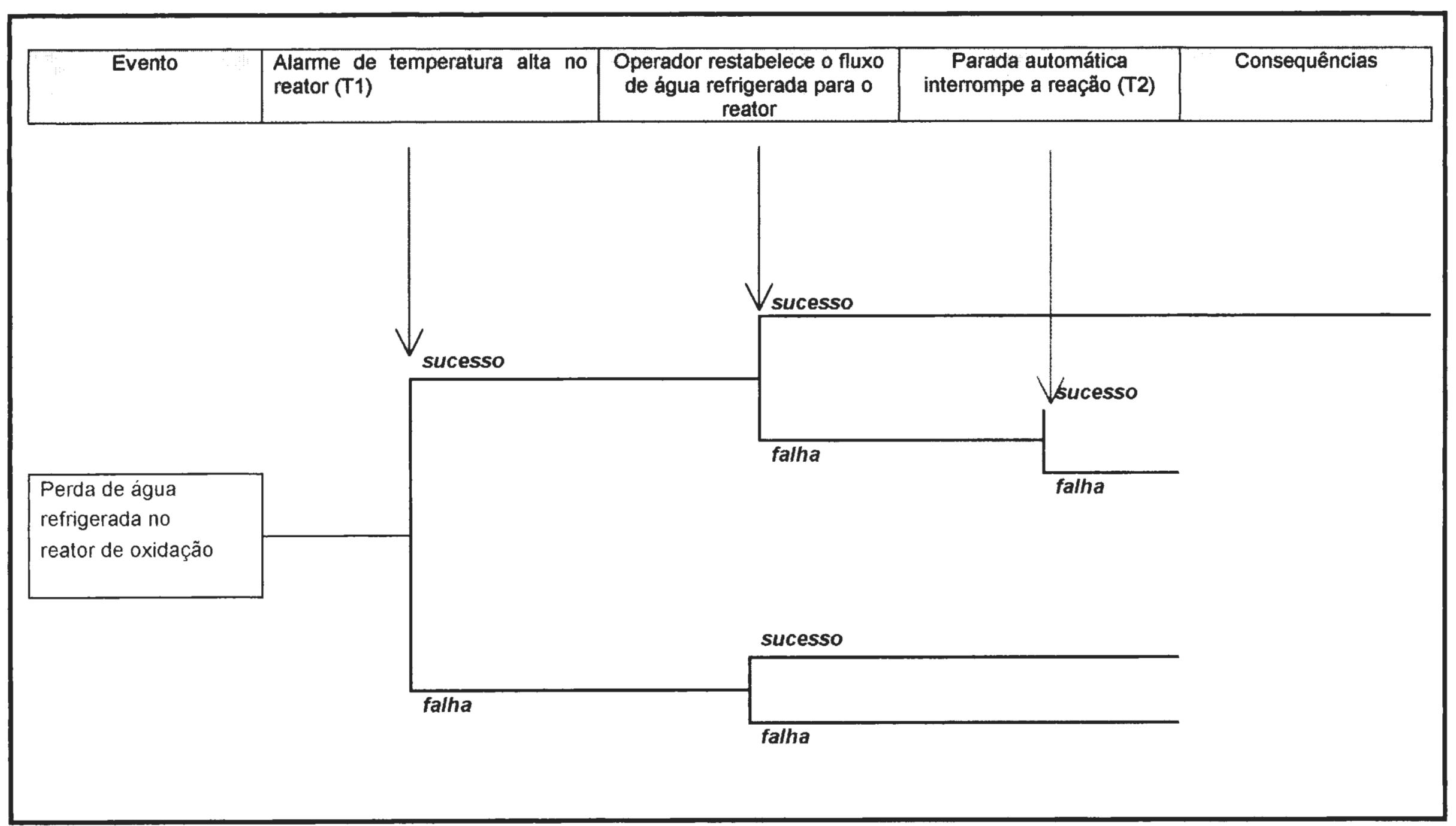


segurança), pois o alarme funcionou e o operador pode restabelecer o fluxo de água refrigerada, obtendo sucesso na ação prevista, e o sistema de fechamento (parada automática) não será requisitado e não afetará a realização do evento, indicando condição segura e retomo à operação normal (Fig. 20). O outro caminho suposto, isto é, falha ao restabelecer o fluxo de água refrigerada, contém uma ramificaçăo para o fechamento do sistema, pois ele pode afetar a realizaçăo dos eventos previstos, o que indicaria a necessidade de avaliar a ação do próximo sistema de segurança (parada automática).

A figura 20 representa ainda o exemplo completo de uma $A E$ para um processo industrial, analisando o risco de um evento base e definindo as conseqüencias da realização dos eventos subsequentes. Esse exemplo considera somente o efeito sobre o processo.

Após a identificação das falhas e sucessos obtidos em cada ramificação e caminhos resultantes da análise do processo proposto, o técnico deverá concluir a AE com uma descrição precisa das realizações dos eventos determinados. Uma vez descritas as possíveis consequências, o técnico poderá definir uma classificação das mesmas, baseado na severidade do dano previsto. No caso de existirem dados numéricos relativos à probabilidade de ocorrência de cada uma das ramificações ou caminhos, pode ser calculada a estimativa da probabilidade de realização do evento, tornando a técnica, que é qualitativa, em quantitativa. Outra possibilidade é a simples classificação do risco de acidente e, a partir desse número ou conceito, definir prioridades para medidas adicionais de segurança e prevenção.

\subsubsection{Análise da metodologia}

Para o propósito deste trabalho, que visa avaliar o risco ao meio ambiente dos processos e operações numa empresa siderúrgica através da aplicação de técnicas de análise de risco adaptadas da área de segurança, o conceito adotado pelo CCPS (1985) deve ser modificado para incluir os aspectos ambientais.

Para o presente trabalho, a AE deve sofrer alterações nas suas etapas 1,2 e 4, visto que, além dos sistemas de segurança, de alarmes ou procedimentos operacionais próprios da prevenção de acidentes industriais, os procedimentos para prevenção do risco de um acidente com conseqüências ambientais devem ser discutidos, incluindo possiveis sistemas ou mecanismos de proteção ambiental, tais como possibilidades de evacuação de uma área, manutenção de área para receber eventuais derrames, desvios nos sistemas de drenagem, etc..

O procedimento aplicado para a construção da $A E$, quando se considera sua aplicação à análise de risco ambiental, não necessita modificações. O processo decisório quanto ao sucesso ou falha de um procedimento operacional para prevenção do risco ambiental deverá ser sempre baseado no sucesso ou na falha de sua execução, dirigindo a trilha para a descrição final do acidente ambiental.

Essas consequências poderão incluir desde a volta à normalidade operacional do processo analisado até efeitos ambientais, patrimoniais e à saúde humana, considerados inaceitáveis. Evidentemente, a técnica prevê somente resultados levando em conta o patrimônio, a parada de produção, perda de produtos e danos à saúde humana.

\subsubsection{Proposta de aprimoramento da Árvore de Eventos - Ambiental (AE-A)}

A análise de risco através da $A E$ considera que, para a maioria dos acidentes, um evento base ou causador é seguido de falhas adicionais, antes da realização do efeito final. A AE deve explorar todas as possibilidades de realização das falhas das medidas de segurança, a começar pelo evento causador. Para adequar o uso da $A E$ para analisar a possibilidade de um evento vir a resultar em danos ambientais, algumas modificações devem ser incorporadas à técnica existente. Não se trata, aqui, de fazer pequenas mudanças de ordem gráfica ou de indicação, mas sim de alterar ou aprimorar alguns dos processos de construção da $A E$, para que possa atender à demanda do presente trabalho, objetivando analisar os riscos ambientais de um processo siderúrgico, ou outra atividade industrial. 
Figura 20. AE completa, incluindo as consequências da realização do evento base

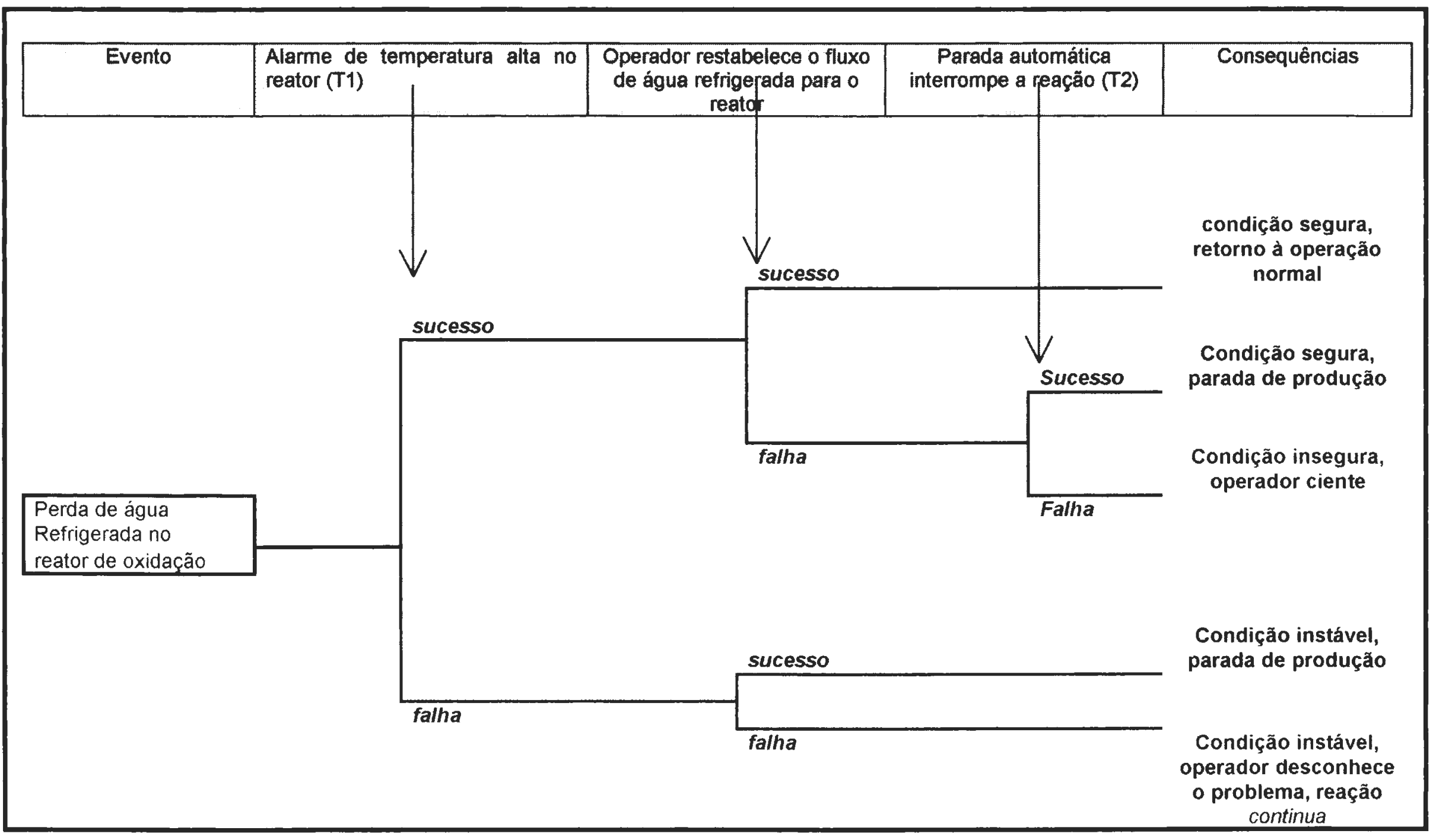


Como visto, o CCPS (1985) propõe quatro etapas para a elaboração da AE. Neste trabalho, essas etapas serão mantidas, porém modificadas no seu conteúdo para conter também a análise do risco ambiental.

A seguir, serão descritas essas etapas, já incorporando a variável ambiental.

\section{Etapa 1 - Identificação do evento base de interesse}

O evento base deve ser um risco já identificado anteriormente. É proposto que esse evento base seja determinado através da APR-A (ambiental), considerando a prioridade encontrada durante a classificação do risco ambiental. Os riscos que apresentarem as classes mais altas, ou seja, a falha do sistema de segurança poderá degradar o meio ambiente, contaminando solo e água, causando morte de espécimes ou a proibição de uso de recursos naturais e áreas cultivadas (Classe III - crítica) e tornando o meio impróprio para a manutenção e reprodução da vida animal e/ou vegetal (Classe IV - catastrófica), deverão ser considerados.

Esses eventos, considerados os mais sérios, pois podem redundar em acidentes, para os quais não estão previstos sistemas de segurança ou ocorre a falha em sistemas ou procedimentos existentes, são tidos como inadmissíveis sob o ponto de vista ambiental. A sua seleção deve ser criteriosa e fundamentada na APR-A e nos critérios adotados para a sua elaboração.

Os riscos constantes na Classe II - marginal ou limítrofe, da APR-A eventualmente poderão necessitar uma análise através da $\mathrm{AE}-\mathrm{A}$, desde que o resultado da realização do acidente dependa de medidas de segurança ou procedimentos cuja falha ocorra com alta probabilidade, como, por exemplo, a ausência temporária de um equipamento de contenção de vazamentos, ou bombas, que devam atender a mais de uma área, dentro da fábrica ou usina. O fato pode ocorrer justamente por ser o risco classificado como limítrofe, pela existência do equipamento de contenção ou bomba, citados.

\section{Etapa 2 - Identificação dos sistemas de segurança previstos para o evento de interesse}

O CCPS (1985) relata vários sistemas de segurança para evitar a ocorrência de um determinado acidente, envolvendo os sistemas de atuação automática, alarmes, respostas operacionais e uso de barreiras para conter ou limitar os efeitos de um acidente. Evidentemente, cada um desses sistemas pode ter outro sistema de segurança, que se pressupõe que entre em operação no caso de falha do sistema principal. É o caso dos sistemas redundantes de segurança.

Para efeito de sua aplicação na análise de risco ambiental, a AE-A deve receber a contribuição de outras formas de segurança, ampliando ou complementando as citadas pelo CCPS (1985).

Evidentemente, os sistemas automáticos e de alarme (sonoro ou visual) foram projetados para atuar em qualquer "não conformidade" do sistema operacional ou de armazenamento. Esses sistemas de segurança não têm como sofrer alterações para incluir o controle de eventos com consequências ambientais.

As operações desenvolvidas pelos técnicos responsáveis pelas operações industriais ou de armazenamento, ao contrário dos sistemas mecânicos ou eletrônicos, podem incluir sistemas de segurança que objetivem exclusivamente a proteção ambiental. Dessa maneira, a AE-A deve incorporar alguns itens, para melhor antecipar as ações corretivas no caso de ocorrência do evento base.

Neste caso, a resposta operacional, prevista no sistema de segurança e que deve ser executada pelo operador do processo, deve supor:

- a possibilidade de geração de residuos líquidos e/ou sólidos e emissões atmosféricas;

- o desvio de fluxos para outros sistemas ou para tanques de armazenamento;

- a descarga de líquidos em contenções, galerias, áreas abertas, corpos hidricos, etc.

- disposição de produtos ou resíduos sólidos em contenções, caçambas, áreas abertas, etc..

- reações secundárias devido à liberação intencional (operacional) de gases e vapores. 
Essas situações normalmente não são consideradas na elaboração da $A E$, visto que os sistemas de segurança pretendem proteger o sistema operacional, a produção e a saúde do operador. Neste caso, a resposta operacional, como planejada, prioriza ações e manobras para resguardar a empresa de perdas e danos patrimoniais e/ou de produção, que poderiam resultar da ocorrência de um evento com consequências inaceitáveis. A incorporação dos fatos elencados acima deve transformar o conceito pré-existente e direcionar a análise de risco para avaliar os possíveis riscos contidos nas operações emergenciais contidas no sistema de segurança existente ou planejado.

Para se proceder à avaliação das hipótese de ocorrência dos acidentes o analista deve estimar inicialmente quais as propriedades mais importantes da substância perigosa que estará sendo liberada para o meio. Segundo KAYES (1985), essas propriedades são:

\section{Estado (fase) - líquido, gás ou ambas as fases \\ Pressão \\ Temperatura \\ Inflamabilidade e \\ Toxicidade}

Após essa definição, o técnico responsável pela realização da análise de risco poderá fazer uso da ávore de falhas para definiçăo de caso, conforme a figura 21, e a partir dela deverá determinar qual AE-A ele deverá usar para melhor avaliar as hipóteses de ocorrência de um acidente com conseqüência ambiental. Ao analisar a figura, as ramificações indicarão ao técnico quais caminhos a seguir. No caso de haver a liberação de substância classificada como tóxica e inflamável, ambas as ramificações devem ser avaliadas. Às substâncias apresentadas em duas fases, isto, é líquida e gás, o técnico deverá aplicar a árvore para liberação ou vazamento de líquidos.

Em caso de vazamento de substâncias tóxicas líquidas, poderá não haver formação de nuvem de material, embora possam ser produzidos vapores tóxicos. Nesses casos, os danos potenciais provavelmente não serão sentidos fora das empresas, e provavelmente não serão necessários modelos de avaliação. Entretanto, devem ser avaliados o solo e a distância de drenagem até rios, estuários, zonas costeiras, represas e outras áreas sensiveis.

Para as emissóes de gases que sofrem ignições ou formam nuvens gasosas, deve-se avaliar: 1) diretamente: as fatalidades e os danos materiais dentro e fora da empresa; 2) indiretamente: determinar se o fogo/explosão pode afetar outros equipamentos que contenham materiais perigosos, ampliando os efeitos do acidente. Nesses casos, sugere-se a aplicação da $A E-A$ Inflamável, conforme sugerido na figura 22.

Para os líquidos inflamáveis ou tóxicos, o vazamento deve ser tratado como uma simples fase ou compreendendo as duas propriedades (tóxico e inflamável), dependendo das condições termofísicas nas quais o estudo está sendo considerado. Nesse caso, o estudo deve incluir: 1) formação de poças com líquido estabilizado a pressão e temperatura ambiente; no caso onde a ignição é considerada relevante, deve-se avaliar a onda de calor de um incêndio na poça. Entretanto, se a possibilidade de ignição for pequena, deve ser levada em conta a possibilidade de danos ao solo e águas superficiais ou subterrâneas; 2) para gases que são estocados liqüefeitos por refrigeração, em caso de vazamento poderá ser formada uma nuvem de gás; nesse caso, sugerese usar a $A E-A$ : Líquido inflamável ou tóxico, aplicando-se os passos da figura 23.

Para o vazamento de gases tóxicos, a densidade da nuvem formada deverá auxiliar na decisão quanto ao estudo a ser realizado. A figura 24 apresenta os principais sistemas de segurança ou procedimentos operacionais que deverão ser acionados, automaticamente ou não, para se avaliar a evolução do evento estudado e as consequências ambientais.

O exame completo da seqüência de acidentes envolvendo as circunstâncias descritas deverá requerer a estimativa da quantidade de material estocado e liberado no caso de um acidente, e o dano potencial da sua realização, através da Árvore de Eventos - Ambiental (AE-A). $O$ dano 
Figura 21. Árvore de falhas para definição de caso (seg. KAYES, 1985)

\begin{tabular}{|c|c|c|r|r|}
\hline Início & Risco & Fases & Liberação & AE-A sugerida \\
\hline
\end{tabular}

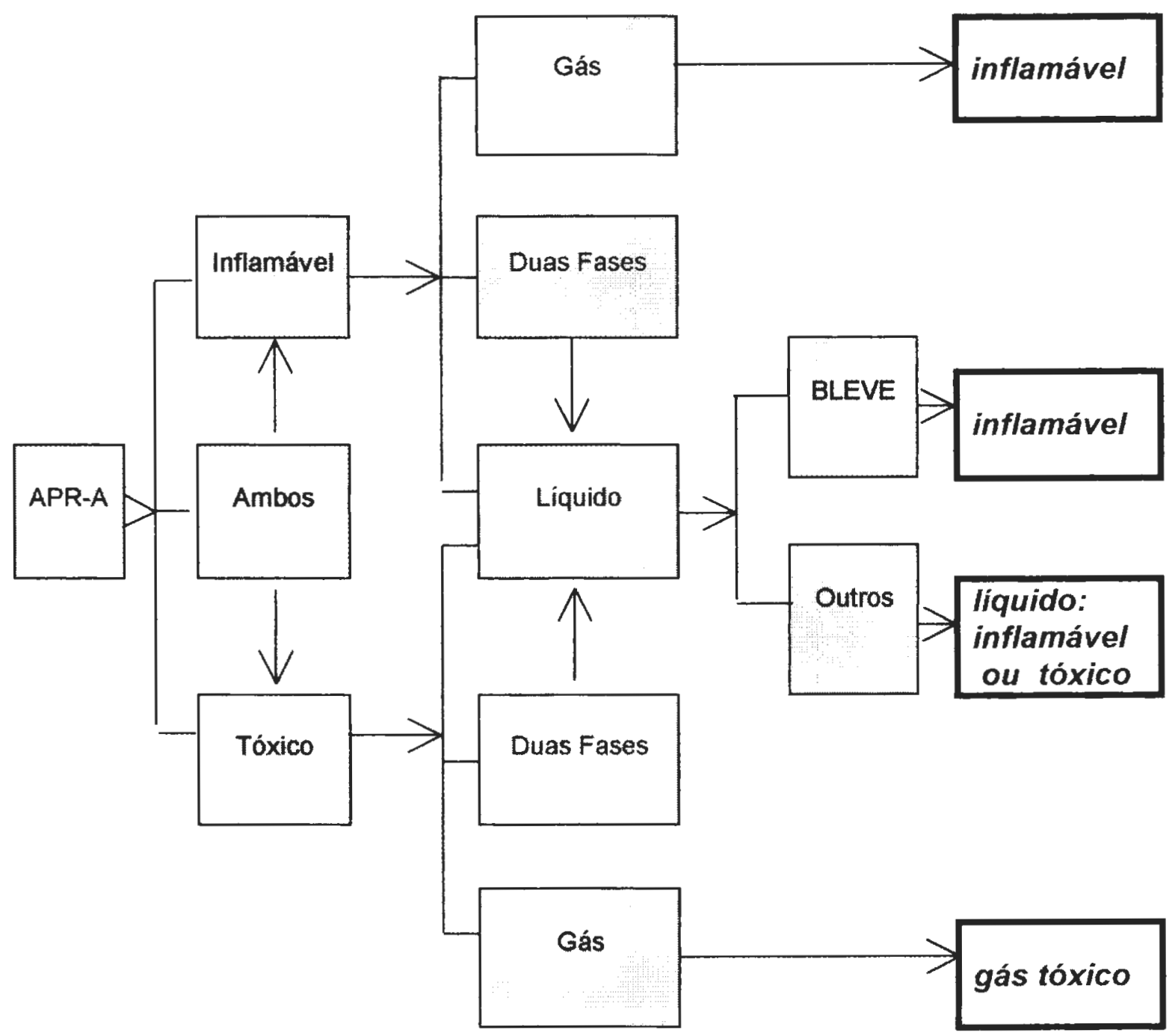

potencial de cada ramificação da Árvore é indicado nas figuras 22,23 e 24 como efeitos ambientais. Os efeitos são indicados por algarismos de 1 a 11 e a descrição de sua correspondência consta da tabela 23.

\section{Etapa 3 - Construção da AE-A}

O procedimento para construção da $\mathrm{AE}$ não necessita modificações para atender à análise de risco ambiental. Como se trata de verificar quais as consequências ambientais advindas da efetivação de um evento conhecido e o desempenho das medidas de segurança planejadas, avaliando o sucesso ou falha dessas medidas, o procedimento atende perfeitamente às necessidades e objetivos de uma análise de risco de acidentes com efeitos danosos ao meio ambiente.

Assim, não está sendo proposta modificação na construção da AE-A. 
Figura 22 - Liberaçåo de substáncias INFLAMÁVEIS

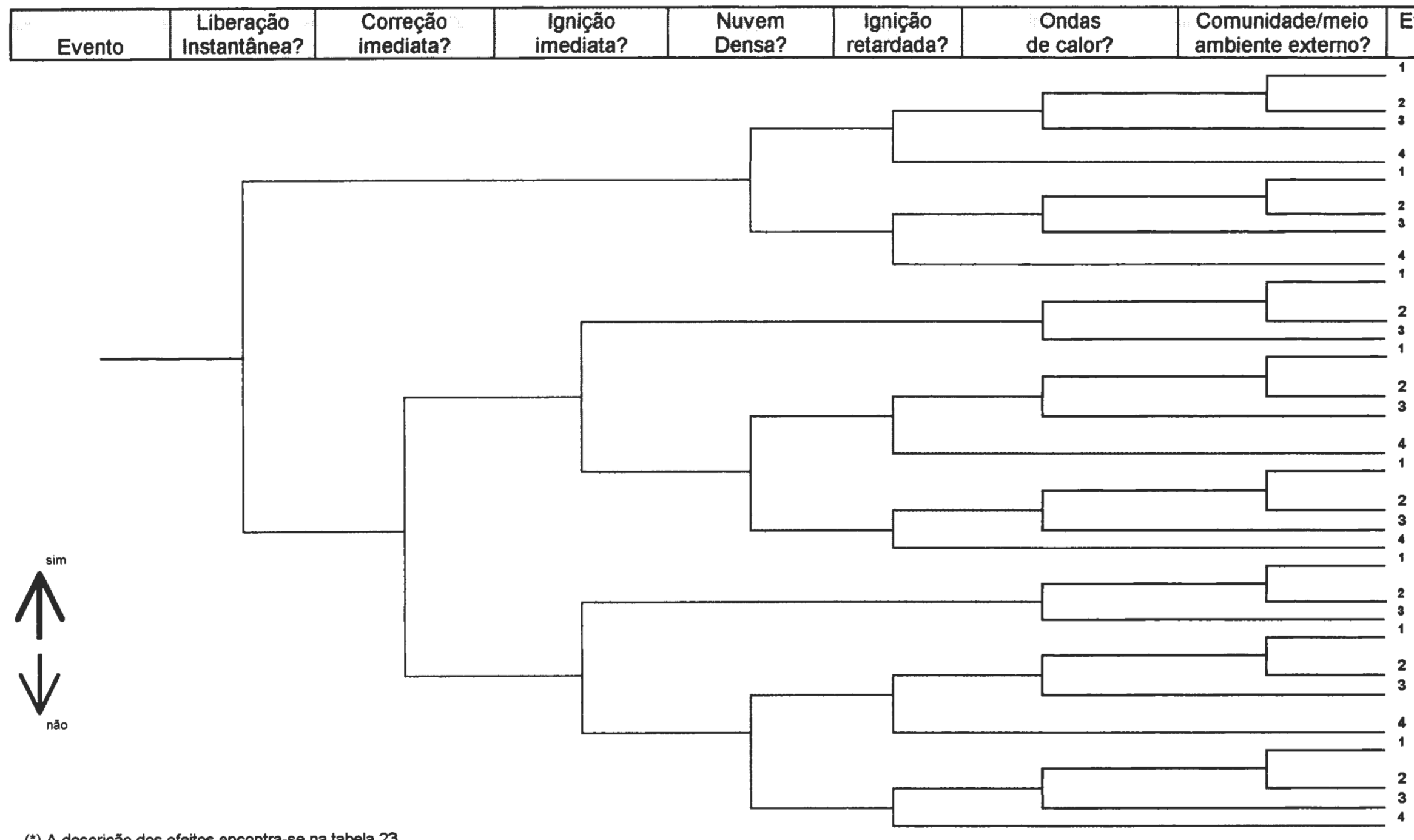



Figura 24. Liberação de GASES TÓXICOS

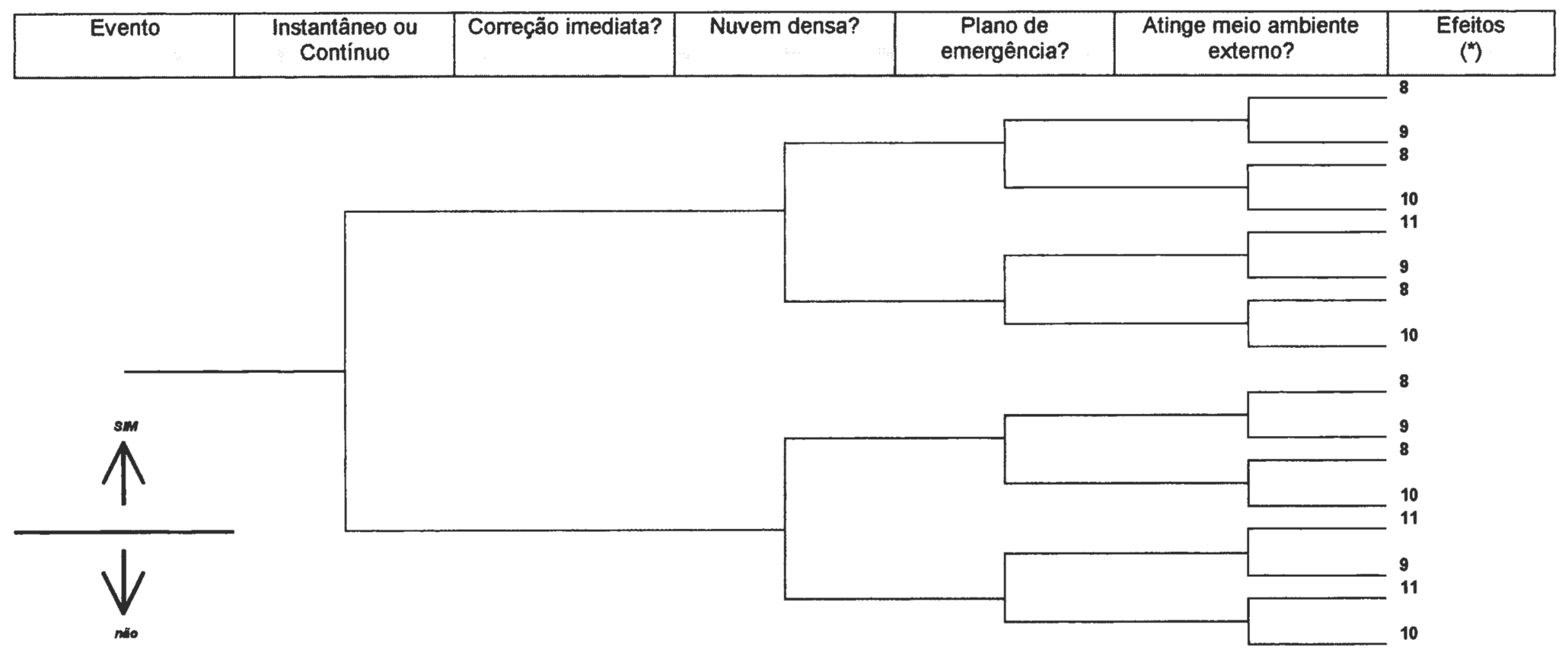

(“) A descriçăo dos efeitos encontra-se na tabela 23. 


\section{Etapa 4 - Descrição das consequências da realização do evento base}

A análise de risco ambiental através da aplicação da AE-A considera a efetivação dos eventos subsequentes de um determinado evento iniciante ou base. Para sua aplicação prática na análise de um projeto ou de uma atividade já estabelecida, a AE apresentada pelo CCPS (1985) deve contemplar os possiveis danos ao meio ambiente, provocados pela realização do evento base ou dos eventos subsequentes, caso ocorram falhas nas medidas de segurança ou procedimentos planejados ou pressupostos.

O presente trabalho avalia os riscos de acidentes maiores, que possam provocar danos ambientais. Segundo a Diretriz de Seveso, os acidentes maiores são determinados pela ocorrência de incêndio, explosão e vazamentos ou derrames de produtos perigosos. Já os danos ambientais podem ser determinados pelos efeitos sobre os ecossistemas, patrimônio histórico, geológico, arqueológico, etc., sobre a comunidade e os recursos naturais, explorados comercialmente ou não.

Segundo as circunstâncias de realização de um evento base, ou dos eventos subsequentes, são esperados diversos e variados efeitos sobre o meio ambiente biogeofísico e sócio-econômico. Para melhor entendimento e facilidade de aplicação da técnica de análise de risco, apresenta-se, a seguir, as principais consequências ambientais da efetivação de um acidente, observando os três tipos de acidentes independentemente. Como alguns dos acidentes estudados podem resultar em um segundo acidente, como por exemplo o vazamento inicial de uma substância inflamável vir a se transformar em incêndio, alguns dos danos previstos para um evento podem, e devem, aparecer quando for analisado um outro evento, diferente.

\section{Vazamentos líquidos:}

Para efeito de desenvolvimento do trabalho, está sendo considerado que o evento corresponde ao derrame acidental, ou não, de produto líquido ou semilíquido, considerado tóxico conforme classificação da CATBRAS ou outro processo reconhecido oficialmente. São os seguintes os efeitos ambientais decorrentes de um derrame:

- no solo:

contaminação;

morte de vegetação;

morte de culturas;

contaminação que exige remediação do sítio;

restrição permanente de uso;

morte de animais

- em corpos hídricos superficiais:

morte de organismos aquáticos;

restrição temporária de uso para consumo humano ou animal;

restrição permanente de uso do recurso natural;

contaminação de sedimentos;

contaminação com substâncias persistentes;

contaminação com substâncias voláteis;

contaminação com substâncias assimiláveis;

contaminação com óleos e graxas;

contaminação com materiais não solúveis

- em galerias e redes de drenagem:

contaminação das vias de escoamento com substâncias persistentes ou fixas;

contaminação com óleos e graxas;

contaminação com materiais tóxicos sedimentáveis

- em corpos hídricos subterrâneos

restrição temporária de uso para consumo humano ou animal;

restrição permanente de uso para consumo humano ou animal;

contaminação com substâncias persistentes;

contaminação com substâncias voláteis;

contaminação com substâncias assimiláveis; 
contaminação com óleos e graxas;

contaminação com materiais não solúveis

\section{Vazamentos de gases ou vapores}

Considera-se o vazamento acidental ou não de gases ou vapores classificados como tóxicos pela CATBRAS ou outro processo reconhecido oficialmente. São os seguintes os efeitos ambientais decorrentes de um vazamento de gases ou vapores tóxicos:

- sociais:

intoxicação, irritação;

morte;

restrição de uso temporário de uma região;

danos a patrimônios sociais (histórico, geológico, etc.);

odores prejudiciais

- econômicos

perda de áreas cultivadas;

restrição de uso de áreas cultivadas;

perda de valor patrimonial das propriedades;

restrição ao uso de meios de transporte

- fauna/flora

morte de vegetação;

danos às áreas protegidas;

morte de animais;

restrição temporária ao uso ou acesso à área ou recurso natural;

restrição permanente ao uso da área ou recurso natural

\section{Geração de produtos ou residuos sólidos}

Durante uma ação operacional emergencial, vários procedimentos podem ser indicados e efetivados. Algumas dessas medidas de segurança podem indicar a necessidade de descarte de produtos ou de resíduos sólidos, classificados como perigosos. Nas análises de risco de processo, a possibilidade de desvio de produtos ou resíduos sólidos é considerada, e a alternativa de dispôlos no solo, sem proteção, pode ser levada em conta, sem uma avaliação dos riscos ambientais que poderão ocorrer, tais como:

- contaminação do solo que permite a remediação e uso da área de disposição

- contaminação do solo, impossibilitando o uso da área de disposição

- geração de gases/vapores tóxicos a animais e vegetais em áreas próximas

- odores prejudiciais

Incêndio

Os acidentes com realização de incêndio, em um processo siderúrgico, tem, conforme dados dos bancos de dados disponiveis (CADAC da CETESB, SONATA), pouco impacto direto ao meio ambiente.

A principal característica de um incêndio com possibilidade de causar danos ambientais é a formação de nuvens de gases e/ou vapores provenientes da combustão ou de fumaça negra, proveniente da combustão incompleta. A propagação do calor gerado em incêndios de grande proporção também pode ser motivo de dano ambiental, principalmente se houver, nas imediações do incêndio, algum tipo de vegetação suscetível de queima por exposição às ondas de calor não controladas. Assim sendo, são os seguintes os efeitos ambientais decorrentes de um incêndio, aqui considerado como capaz de produzir danos ambientais, diretos e indiretos:

- efeitos diretos da propagação do calor gerado:

morte de vegetação e animais;

restrição temporária de uso da área impactada;

perda de áreas cultivadas

- efeitos diretos da geração de fumaça, gases e vapores

os mesmo efeitos relacionados para vazamentos de gases e/ou vapores; 
restrição temporária ao uso de vias de transporte, pela formação de fumaça que dificulta a visão;

deposição de material particulado sobre a vegetação

- efeitos indiretos, devido às medidas de combate ao incêndio

formação de efluentes líquidos, através do uso de produtos químicos, espumas ou água que, por característica própria ou contato com outros produtos, tornam-se tóxicos, e que são descartados em redes de drenagem, solo, corpos hídricos superficiais e subterrâneos. Neste caso, deve-se considerar os mesmos efeitos negativos ao meio ambiente, conforme relacionados para vazamento de líquidos.

\section{Explosăo}

Do mesmo modo que os incêndios, os acidentes com ocorrência de explosões, pouco efeito apresentam sobre o meio ambiente.

No processo siderúrgico, incluindo as operações de desmontes nas minerações, a probabilidade de explosão concentra-se nos processos que envolvem altas pressões e temperaturas (regenerador de gases, aciarias, alguns sistemas de despoeiramento, etc., no armazenamento de gases e líquidos e nas minerações).

Os processos produtivos, embora não sejam necessariamente enclausurados, encontram-se em áreas próximas de outros processos ou edifícios que podem amenizar os efeitos de uma explosão. Os explosivos mantidos em paióis, para uso nas minerações, têm sistemas de segurança que reduzem com eficiência os danos ambientais. Finalmente, o armazenamento de liquidos e gases explosivos é, das fontes identificadas, o que oferece maiores riscos de efeitos negativos sobre o meio ambiente.

As principais características de uma explosão com possibilidade de causar danos ambientais são: deslocamento de ar, geração de calor, formação de nuvens de gases e/ou vapores, e formação de nuvens de material particulado (pó).

A formação de nuvens de pó é um efeito característico da explosão em áreas de mineração, sendo os efeitos ambientais caracterizados por:

- deposição de material particulado sobre a vegetação;

- restrição temporária ao uso de vias de transporte, pela formação da nuvem de pó e dificuldade de visão;

- ação sobre o aparelho respiratório de animais expostos.

A formação de nuvens de gases e/ou vapores gerados na explosão de gases, líquidos e processos, provocará os mesmos resultados negativos previstos para o vazamento de gases e/ou vapores, já descritos anteriormente.

O calor provocado pela explosão, se o efeito se manifestar além dos limites da fábrica e atingir áreas sensiveis, provocará os mesmos resultados negativos previstos anteriormente para a ocorrência de incêndio. Entretanto, a exposição de organismos vivos ao calor gerado na explosão deverá ser avaliada pelo técnico que está aplicando a $A E-A$, a partir do conhecimento de que será gerada uma onda de calor, de tempo e intensidade limitada, que pode ser determinada através de cálculos, baseados na quantidade e tipo do produto em avaliação e as distâncias das áreas sob influência do evento.

Os efeitos ambientais provocados pelo deslocamento súbito de ar serão sentidos principalmente pela vegetação arbustiva e/ou arbórea e animais de médio/grande porte. Nesse caso, os efeitos esperados sobre o meio ambiente, se este for exposto à onda de choque provocada pelo deslocamento, serão:

- morte de animais;

- danos à vegetação;

- danos a áreas cultivadas;

- danos aos patrimônios sociais. 
A tabela 23 relaciona os principais efeitos ambientais decorrentes de acidentes conforme previstos durante a aplicação da $A E$ e sugeridos neste trabalho, como uma forma de aprimorar o entendimento e aplicabilidade da $A E$ original. A descrição dos efeitos é indicada por algarismos, variando de 1 a 11 , relacionando cada classe de efeito a um ou mais danos aos meios estudados. Nas figuras 22 a 24 utiliza-se essas classes de efeito para identificar os danos decorrentes dos eventos previstos.

Tabela 23. Descrição dos efeitos ambientais indicados nas AE-A das figuras 22 a 24

\begin{tabular}{|c|c|}
\hline Efeitos & Descrição \\
\hline 1 & $\begin{array}{l}\text { Ocorrem danos substanciais a severos à vegetação e animais, restrição temporária } \\
\text { da área afetada, perda de áreas cultivadas, geração de fumaça preta e nuvens } \\
\text { tóxicas, deposição de material particulado sobre vegetação; possibilidade de } \\
\text { poluição das águas por produtos usados na extinção do incêndio }\end{array}$ \\
\hline 2 & $\begin{array}{l}\text { O incêndio ocorre com perda patrimonial e de produtos, possíveis danos à saúde } \\
\text { humana; possibilidade de poluição das águas por produtos usados na extinção do } \\
\text { incêndio }\end{array}$ \\
\hline 3 & O vazamento não provoca lesões ou danos ambientais \\
\hline 4 & $\begin{array}{l}\text { Ocorrem danos à propriedade, com perda de produção, retorno ao processo } \\
\text { (correção e/ou operação) }\end{array}$ \\
\hline 5 & $\begin{array}{l}\text { Os resíduos gerados deverão ser dispostos adequadamente como classe I e com } \\
\text { autorização do órgão ambiental competente }\end{array}$ \\
\hline 6 & $\begin{array}{l}\text { Haverá contaminação do solo, com exigência de avaliação posterior da extensão da } \\
\text { contaminação incluindo aqüiferos subterrâneos, e remediação do local. Poderá } \\
\text { haver necessidade de incineração do solo contaminado; geração de nuvens tóxicas } \\
\text { e de odores prejudiciais, restrição de uso da área, restrição ao uso da água } \\
\text { subterrânea }\end{array}$ \\
\hline 7 & $\begin{array}{l}\text { Poderá haver danos severos ou morte da fauna/flora aquáticas, perda de qualidade } \\
\text { do corpo hídrico, perda do potencial de cultivo e pesca, danos econômicos, } \\
\text { contaminação dos sedimentos, comprometimento de rede de drenagem e galerias }\end{array}$ \\
\hline 8 & $\begin{array}{l}\text { Ocorrem danos severos e morte na população; restrição de uso temporário da } \\
\text { região afetada; odores prejudiciais; perda de áreas cultivadas; restrição ao uso de } \\
\text { meios de transporte; danos substanciais e severos à fauna/flora, morte de animais; } \\
\text { perda de qualidade do ar }\end{array}$ \\
\hline 9 & $\begin{array}{l}\text { Ocorrem danos à propriedade, com perda de produção, retorno ao processo } \\
\text { (correção e/ou operação); lesões leves a severas }\end{array}$ \\
\hline 10 & $\begin{array}{l}\text { Ocorrem danos à propriedade, com perda de produção, retomo ao processo } \\
\text { (correção elou operação); lesões severas elou mortes }\end{array}$ \\
\hline 11 & $\begin{array}{l}\text { Dependendo das condições para dispersão dos gases e proximidade da população } \\
\text { externa, poderão ocorrer lesões leves a médias à saúde humana; danos médios à } \\
\text { fauna da área de influência }\end{array}$ \\
\hline A & Aplicar AE-A para substâncias inflamáveis \\
\hline $\mathrm{B}$ & Aplicar AE-A para substâncias tóxicas \\
\hline
\end{tabular}




\subsection{APLICAÇÃo PRÁtICA DA ANÁLISE dE RISCO AMBIENTAL A UM PROCESSO SIDERÜRGICO}

A produção, integrada ou não, de ferro e dos diversos tipos de aço, emprega vários processos distintos e a geração e armazenamento de subprodutos e resíduos perigosos. No item 3.3 foram identificados os processos produtivos, operacionais, de transporte e armazenamento que apresentam riscos de causar acidentes ambientais (Tab. 3), bem como as substâncias envolvidas nesses processos (Tab. 5) e que classificam a atividade, ou o setor, como de risco. A análise desses dados evidencia ser o processo siderúrgico uma atividade que envolve riscos de acidentes maiores, conforme definição adotada pela Diretriz de Seveso. A presença de inúmeras substâncias tóxicas, processos que empregam altas temperaturas e pressões, além da produção e armazenamento de grandes quantidades dessas substâncias, por si só já deveriam motivar o administrador a realizar uma análise de risco de processo de forma ampla, abarcando todas as atividades presentes na empresa.

Como resultado da proposição de adoção de técnicas de análise de risco ambiental para um processo siderúrgico, e atentando para os riscos presentes nessa atividade industrial, é efetuada a seguir uma aplicação prática de análise de risco ambiental a uma usina siderúrgica integrada a coque, instalada numa região onde os aspectos ambientais são relevantes.

Os dados industriais citados na análise de risco estão presentes em relatórios técnicos, apresentados em encontros técnicos do setor e outros (CARVALHO FILHO et al., 1987; PEREIRA \& PEDRO, 1992, 1993).

Para efeito de aplicação de análise de risco ambiental a uma empresa siderúrgica, considerando os vários processos e atividades existentes, seria imperativo analisar cada um deles, a fim de primeiramente classificá-los para avaliar o risco presente. Não é objetivo deste trabalho apresentar uma análise de risco ambiental do processo siderúrgico, mas sim apresentar as técnicas alternativas e mais apropriadas para a realização da análise proposta. Assim sendo, para efeito de aplicação prática dessas técnicas, serão considerados alguns processos existentes em uma empresa siderúrgica. Entre eles, será selecionado aquele que apresentar grande risco, que o classifique entre os que devem ser analisados prioritariamente.

O exemplo segue todos os passos propostos anteriormente para a realização da análise de risco ambiental, que podem ser resumidos nas seguintes etapas:

1. identificação do grau de risco do empreendimento;

2. definição das hipóteses de acidentes;

3. avaliação das hipóteses de acidentes definidas.

A seguir, faz-se uma caracterização da região em que está situada a siderúrgica considerada, para entender melhor a aplicação da metodologia proposta.

A usina foi instalada em Cubatão (SP) na década de 60, aproveitando os insumos da região, juntamente com outras indústrias (petroquímicas), vindo a seguir o complexo de fertilizantes (VARGAS-BOLDRINI et al., 1990). Localizada, juntamente com as outras indústrias, numa estreita faixa de terreno sólido de planície entre os manguezais e a escarpa da Serra do Mar, ocupa uma área total de aproximadamente $20 \mathrm{~km}^{2}$ (cerca de $1 / 8$ da área total do município de Cubatão. Encontra-se na cabeceira de uma área estuarina, em que há mistura de água doce e salgada, onde a complexidade da biota excede a dos demais ambientes aquáticos (TOMMASI, 1979). Há que se destacar, também, a vegetação da Serra do Mar - a Mata Atlântica, que, nas encostas próximas a Cubatão, sofre ainda a ação dos poluentes aero-dispersos oriundos do complexo industrial (VARGAS-BOLDRINI et al., 1990).

A ocupação da região de Cubatão ocorreu em função de suas características: área abrigada para o desenvolvimento do porto, proximidade e facilidade de transporte para a região metropolitana de S. Paulo, e boa disponibilidade de água (rio Cubatão e afluentes) e energia elétrica (Usina Henry Borden). 
Nessa região, todos os ecossistemas são altamente produtivos, pois, além da Mata Atlântica e do estuário, há extensas áreas de manguezais, apesar de grande parte ter sido ocupada e degradada. Esses manguezais sofrem um processo ciclico de inundação e drenagem face ao regime de marés, propiciando a retenção das cheias dos rios e a formação de bancos de sedimento, e o desenvolvimento de um ecossistema natural extremamente produtivo. Porém, a ocupação da região por grandes complexos industriais levou as condições naturais de equilíbrio a sofrerem uma alteração radical, devida principalmente a três fatores: aterramento dos manguezais, execução de obras viárias de desmontes e desmatamentos, e fechamento de canais e braços de rios, reduzindo a área geral das seçōes para escoamento das águas e causando elevações das linhas d'água (PEREIRA et al., 1991).

Os rios dessa região caracterizam-se por drenarem áreas íngremes da Serra do Mar, onde se observam as precipitações mais intensas da costa do Atlântico. As séries históricas de postos pluviométricos e fluviométricos permitem relacionar as vazões de picos de cheias com os respectivos períodos de retorno. Normalmente, e de forma simplificada, admitem-se as vazões de $800 \mathrm{~m}^{3} / \mathrm{s}$ para o rio Cubatão e de $400 \mathrm{~m}^{3} / \mathrm{s}$ para o rio Mogi, como as vazões de projeto para obras fluviais. O regime de vazão dos rios da região é de grande interesse para a usina siderúrgica, bem como para as outras indústrias que ocupam áreas adjacentes e da comunidade que habita de maneira dispersa as áreas próximas (PEREIRA et al, 1991).

Originalmente, quase todas as áreas ribeirinhas aos rios Cubatão, Mogi e Piaçaguera inundavamse periodicamente, pois grande parte delas eram manguezais e, como tal, situavam-se ao nivel do mar, pouco abaixo da cota $3,0 \mathrm{~m}$. Com o passar do tempo e a ocupaçäo urbana e industrial, essas áreas foram sendo aterradas, tendo atingido a cota 5,0 e até $5,5 \mathrm{~m}$, como no caso dos terrenos da siderúrgica (PEREIRA et al, 1991).

Numerosos trabalhos foram desenvolvidos na região, especialmente no que se refere ao ambiente estuarino, sendo muitos deles citados em PEREIRA (1985). Outros trabalhos, especialmente sobre a influência da usina e sobre os impactos ambientais de suas atividades (PEREIRA et al., 1991), também contam com descrições detalhadas da região, que serviram de base para a caracterização apresentada. Vários trabalhos realizados na área revelaram teores de metais pesados e compostos orgânicos superiores àqueles recomendados pela legislação, tanto na água, como no sedimento e nos organismos aquáticos (CETESB, 1978; TOMMASI, 1979; PEREIRA, 1985; VARGAS-BOLDRINI \& NAVAS-PEREIRA, 1987; VARGAS-BOLDRINI et al., 1990). Alguns poluentes tóxicos são ainda lançados aos rios e ao canal do estuário, em concentraçōes superiores aos padrōes legais de emissão. Alguns trabalhos NARGAS-BOLDRINI et al, 1990) já haviam revelado que a usina em questão era responsável pela maior carga tóxica lançada no ambiente. Estudos feitos com esses efluentes evidenciaram grande variabilidade com relação à sua toxicidade (PRÓSPERI, 1993).

\subsubsection{Identificaçăo do grau de risco do empreendimento}

Nesta aplicação prática das técnicas de análise de risco ambiental, serão consideradas as seguintes unidades:

- Sinterização

- Coqueria

- Calcinação

- Carboquímicos/subprodutos

- Alto-forno

- Aciaria

- Lingotamento contínuo

- Laminação de tiras a quente

- Laminação de tiras a frio

- Dessulfuração

- Fábrica de oxigênio

Para cada unidade citada, foi aplicada a classificação de risco proposta originalmente pela CETESB, com o uso da CATBRAS (MAKARON, 1992), com a avaliação das unidades, processos 
de produção e armazenamentos existentes e da sensibilidade ambiental, baseada somente nos critérios ali apresentados (Fig. 25 a 35).

Em seguida, para as mesmas unidades, foi aplicada a CATBRAS, com a avaliação das unidades, processos de produção e armazenamento existentes, conforme a versão original e a avaliação da sensibilidade da área circunvizinha, conforme a modificação proposta neste trabalho.

Os resultados da aplicação da CATBRAS original e a modificada estão resumidos nas figuras 25 a 35, e evidenciam algumas reclassificaçōes dos processos avaliados, devidas à proposta deste trabalho.

Figura 25. Classe de risco segundo CATBRAS modificada para: sinterizaçăo

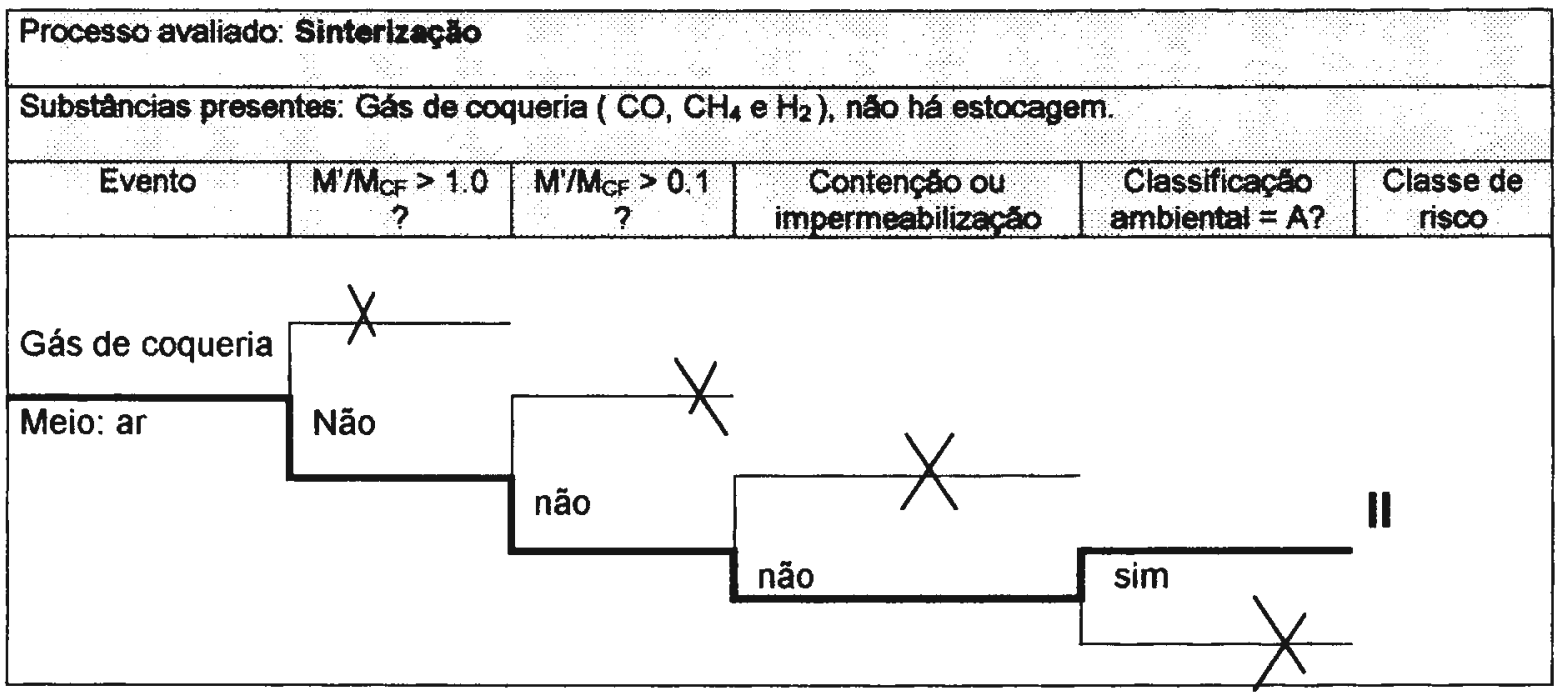

Figura 25A. Classe de risco final para: sinterizaçăo

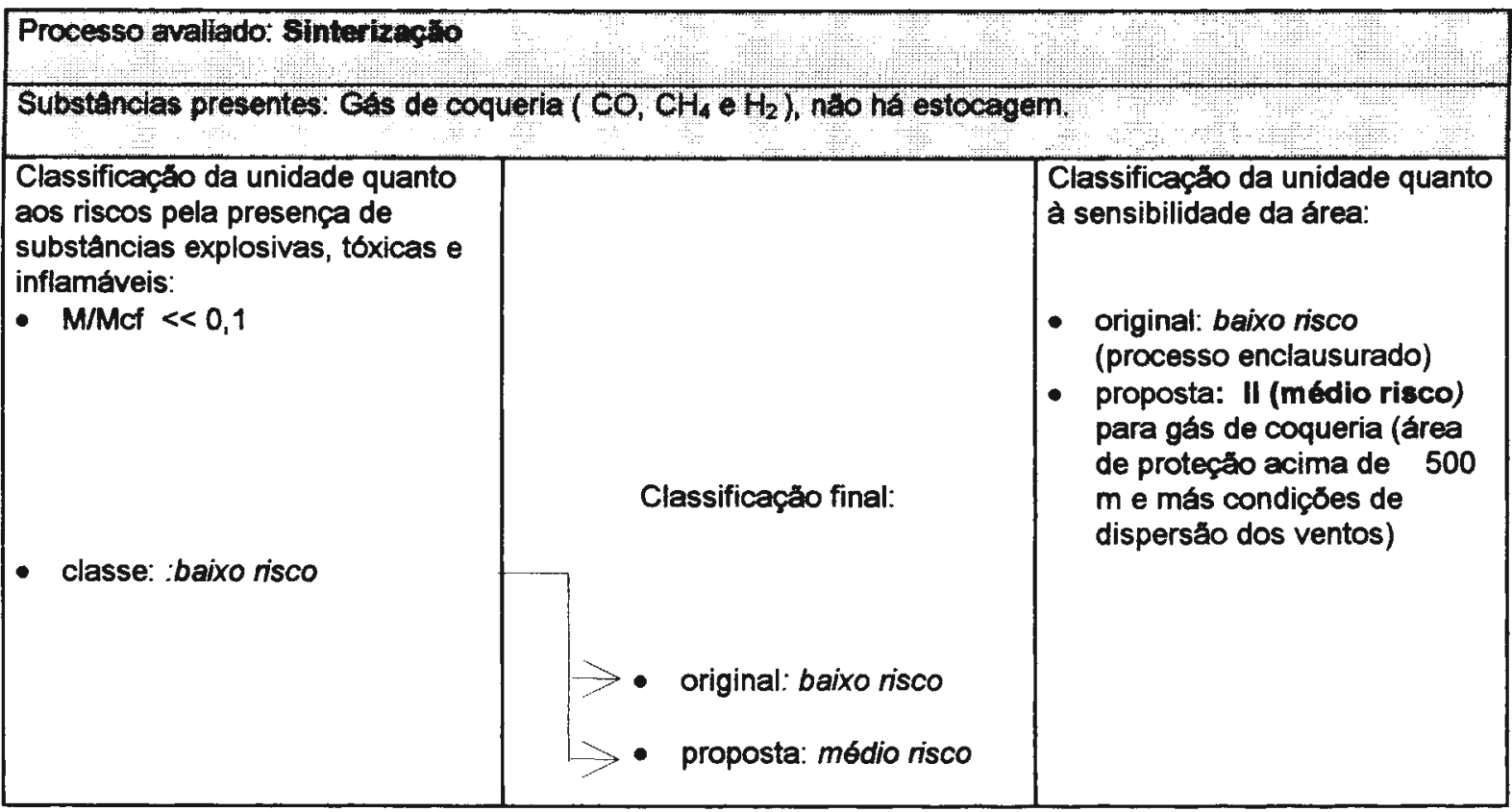


Figura 26. Classe de risco segundo CATBRAS modificada para: coqueria Processo avaliado: Coqueria

Substancias presentes: Coque incandescente, gas de coqueria (CH4, $\mathrm{CO}, \mathrm{H}_{2}$, lloor amoniacal

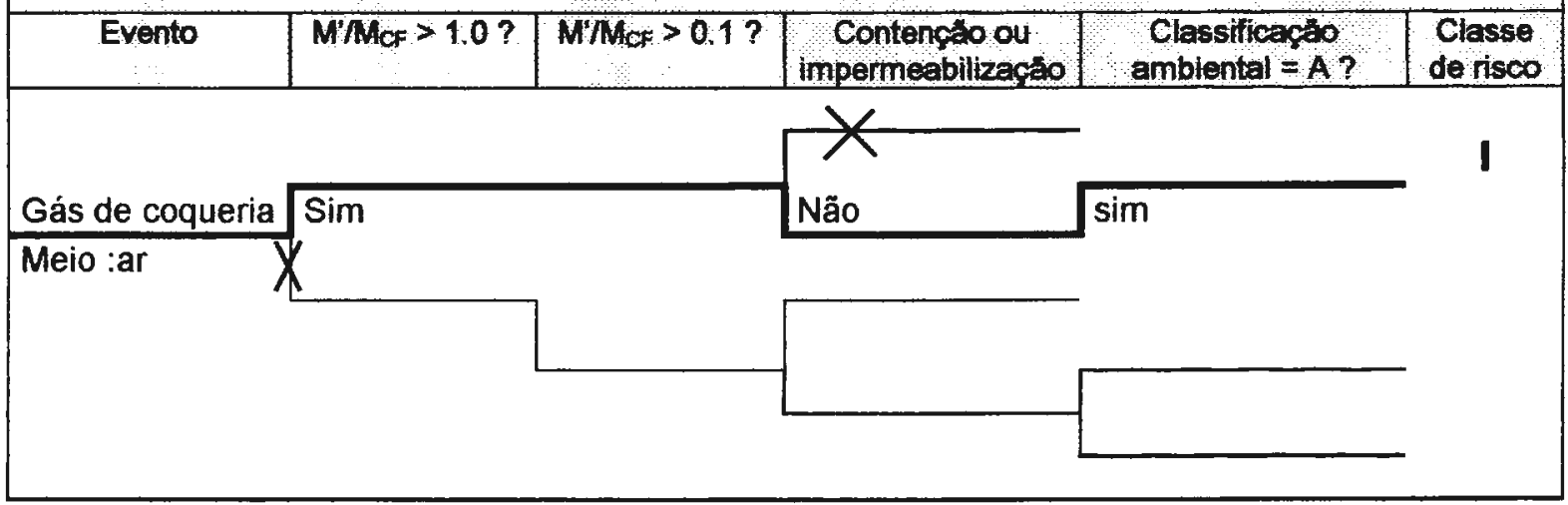

Figura 26A. Classe de risco final para: coqueria

Processo avaliado: Coqueria

Substancias presentes, Coque incendescente, gás de coqueria ( $\mathrm{CH}_{4}, \mathrm{CO}, \mathrm{H}_{2}$, licor amoniaca)

Classificaçăo da unidade quanto

aos riscos pela presença de

substáncias explosivas, tóxicas e inflamáveis:

- $M /$ Mcf $=2,6$

- classe: atto risco

(baseada somente no gás de coqueria)
Classificaça da unidade quanto à sensibilidade da área:

- original: baixo risco

- proposta: I - alto risco (o vazamento sem contençăo de I. amoniacal, acima de 50 litros e receptor classe 7)

- original: atto risco

- proposta: alto risco 
Figura 27. Classe de risco segundo CATBRAS modificada para: calcinaçăo

\begin{tabular}{|c|c|c|c|c|c|}
\hline Processo avaliado. C & blcinack̂o & & & & \\
\hline Substancias present & S. 0100 combusth & el (BPF-baixo te & or de enxofre) e gass o & coqueria $\mathrm{CH}_{4} \mathrm{CC}$ & $\overline{\mathrm{BH}}$ \\
\hline Evento & $M M_{c}=1.0 ?$ & $\mathrm{M} \mathrm{M}_{\mathrm{Cr}}>0,1$ ? & $\begin{array}{l}\text { Contencto ou } \\
\text { impermeabilizacaso }\end{array}$ & $\begin{array}{l}\text { Classificacalo } \\
\text { ambiental }=\mathrm{A} \text { ? }\end{array}$ & $\begin{array}{l}\text { Classe } \\
\text { de risco }\end{array}$ \\
\hline & & & & & II \\
\hline & $X$ & & & $\overline{s i m}$ & \\
\hline Óleo combustivel & $\wedge$ & & $\operatorname{sim}$ & & \\
\hline Meio & não & sim & & & \\
\hline Meio & & & & & \\
\hline
\end{tabular}

Figura 27A. Classe de risco final para: calcinaçăo

\begin{tabular}{|c|c|c|}
\hline \multicolumn{3}{|l|}{ Processo avaliado: Caleinaçlo } \\
\hline Substancias presentes $0100 \mathrm{com}$ & F- baixo teor de enxofre) e & 5 de coqueria ( $\mathrm{CH}_{4} \mathrm{CO}$ e $\mathrm{H}_{2}$ ) \\
\hline $\begin{array}{l}\text { Classificaçá da unidade quanto } \\
\text { aos riscos pela presença de } \\
\text { substáncias explosivas, tóxicas e } \\
\text { inflamáveis: } \\
\text { - M/Mcf }=0,145 \\
\text { - classe: médio risco }\end{array}$ & $\begin{array}{l}\text { Classificaçăo final: } \\
\text { - original: médio risco } \\
\text { - proposta: médio risco }\end{array}$ & $\begin{array}{l}\text { Classificacáa da unidade quanto } \\
\text { à sensibilidade da área: } \\
\text { - original: médio risco } \\
\text { - proposta: II médio risco (a } \\
\text { menos de } 500 \text { m do estuário, } \\
\text { tem contençăo secundária) }\end{array}$ \\
\hline
\end{tabular}


Figura 28. Classe de risco segundo CATBRAS modificada para: carboquimicos

\begin{tabular}{|c|c|c|c|c|c|}
\hline \multicolumn{6}{|c|}{ Processo avaliado Carboquimicos } \\
\hline \multicolumn{6}{|c|}{$\begin{array}{l}\text { Substáncias presentes: piche, alcatráo, óleo creosoto, oleo antracénico, benzeno, tolueno, xileno, } \\
\text { naftaleno, oleo leve, bleo mineral, licor amoniacal, borras oleosas, cal, ácido sulfínco, efluentes contendo } \\
\text { cianeto efenol }\end{array}$} \\
\hline Evento & $M / M_{C F}>1.0 ?$ & $M M_{C F}>0.1 ?$ & $\begin{array}{l}\text { Tem Contencalo ou } \\
\text { impermeabilizaçà? }\end{array}$ & $\begin{array}{c}\text { Classificacalo } \\
\text { ambiental }=\mathrm{A} \text { ? }\end{array}$ & $\begin{array}{l}\text { Classe de } \\
\text { risco }\end{array}$ \\
\hline Orgânicos & \multirow[t]{2}{*}{ Sim } & & & & \multirow[t]{2}{*}{1} \\
\hline & & & não & \multirow[t]{2}{*}{ sim } & \\
\hline Meio: água & & & & & \\
\hline
\end{tabular}

Figura 28A. Classe de risco final para: carboquímicos

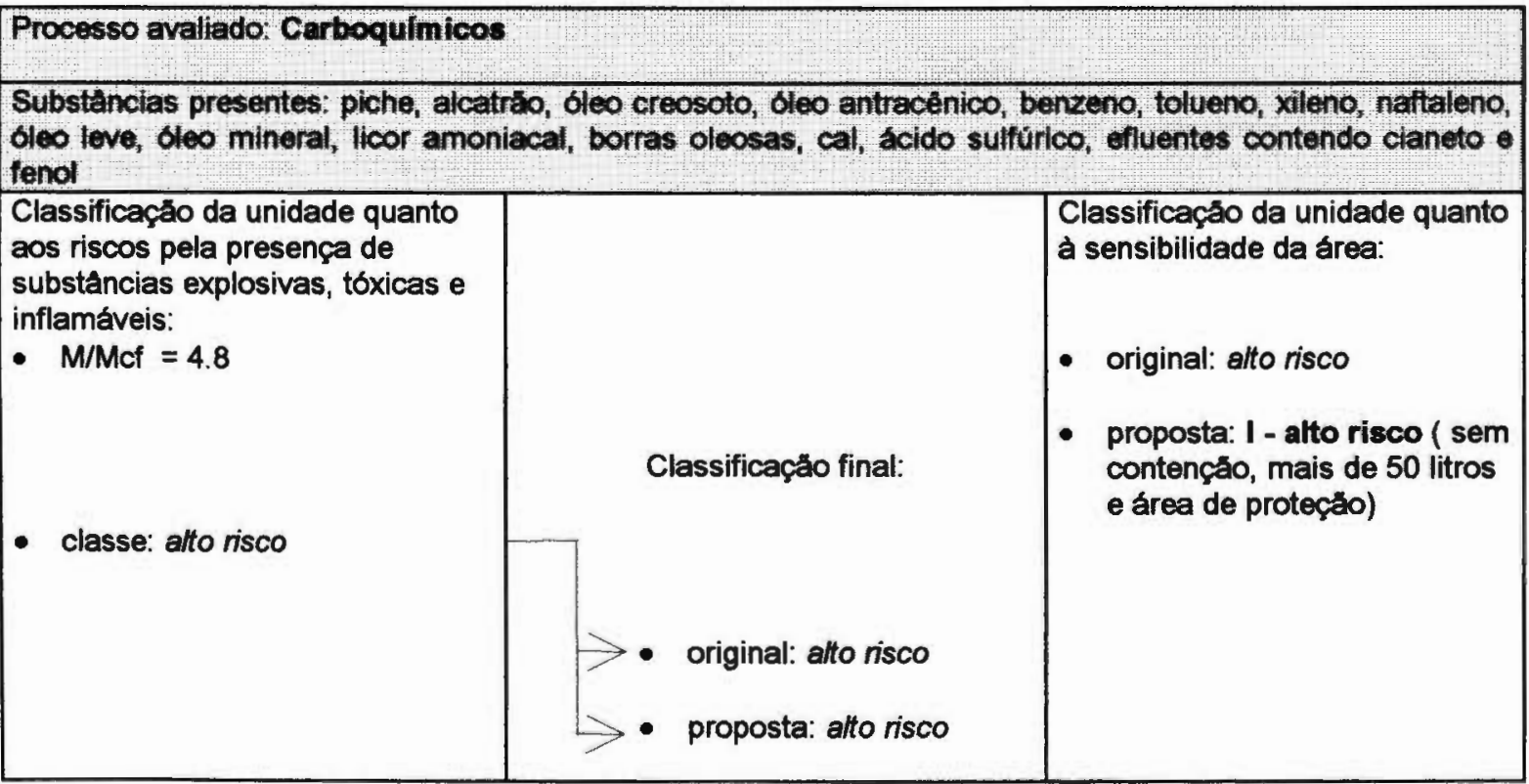


Figura 29. Classe de risco segundo CATBRAS modificada para: alto - forno

\begin{tabular}{|c|c|c|c|c|c|}
\hline \multicolumn{6}{|c|}{ Processo avaliado: Alto-forno } \\
\hline \multicolumn{6}{|c|}{$\begin{array}{l}\text { Substáncias presentes: Gás de alto-fomo }(\mathrm{CO}) \text {, ferro liquido, oxigénio, altas pressóes é temperatura } \\
\text { estocagem de oleo combustivel }\end{array}$} \\
\hline Evento & $\mathrm{M} / \mathrm{Mcr}>10$ ? & $M / M_{C F}>0.1 ?$ & $\begin{array}{l}\text { Tem Contençao ou } \\
\text { impermeabilizaça? }\end{array}$ & $\begin{array}{l}\text { Classiflcaço } \\
\text { ambiental }=\mathrm{A} \text { ? }\end{array}$ & $\begin{array}{l}\text { Classe do } \\
\text { risco }\end{array}$ \\
\hline $\begin{array}{l}\text { Gás de alto- } \\
\text { forno }\end{array}$ & $\operatorname{sim}$ & & não & \multirow[t]{2}{*}{$\operatorname{sim}$} & \\
\hline Meio: ar & & & & & \\
\hline
\end{tabular}

Figura 29A. Classe de risco final para: alto-forno

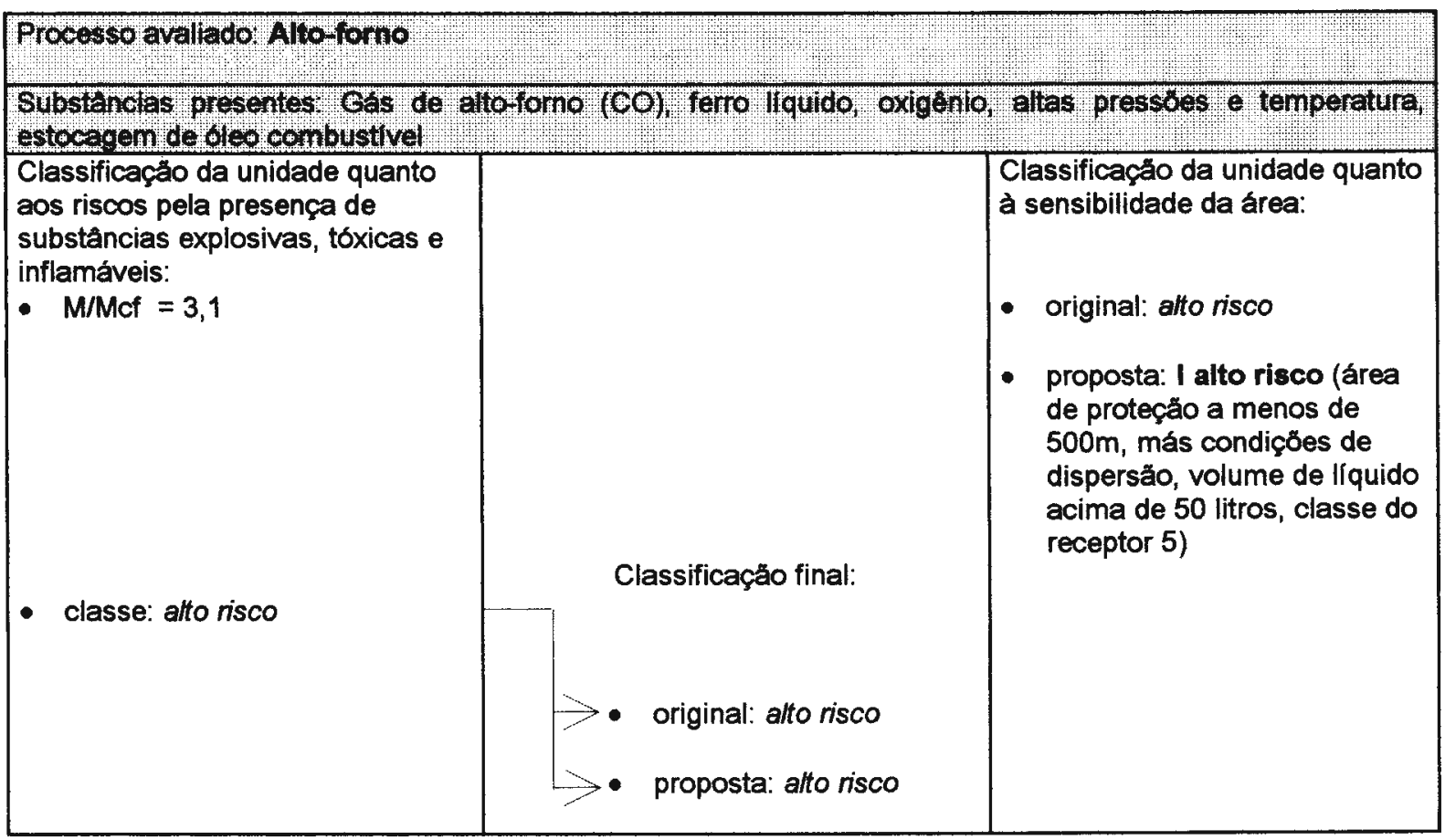


Figura 30. Classe de risco segundo CATBRAS modificada para: aciaria

\begin{tabular}{|c|c|c|c|c|c|}
\hline \multicolumn{6}{|c|}{ Processo avaliado: Aciarla } \\
\hline \multicolumn{6}{|c|}{$\begin{array}{l}\text { Substáncias presentes: Aço liquido, ferro llquido, alta temperatura, barritha, escória llquida, gés de coqueria } \\
\left(\mathrm{CO}, \mathrm{CH}_{4}, \mathrm{H}_{2}\right) \text {, elluentes industriais tóxicos }\end{array}$} \\
\hline Evento & MACF $>1.0 ?$ & $M / M c F>0.1 ?$ & $\begin{array}{l}\text { Contencato ou } \\
\text { impermeabilizacas }\end{array}$ & $\begin{array}{l}\text { Classificacaio } \\
\text { ambiental }=\mathrm{A} \text { ? }\end{array}$ & $\begin{array}{l}\text { Classe } \\
\text { de risco }\end{array}$ \\
\hline $\begin{array}{l}\text { Efluente } \\
\text { industrial }\end{array}$ & $x$ & & & & \\
\hline \multirow[t]{3}{*}{ Meio: água } & Não & & & & \\
\hline & & não & & & II \\
\hline & & & não & Sim & \\
\hline
\end{tabular}

Figura 30A. Classe de risco final para: aciaria

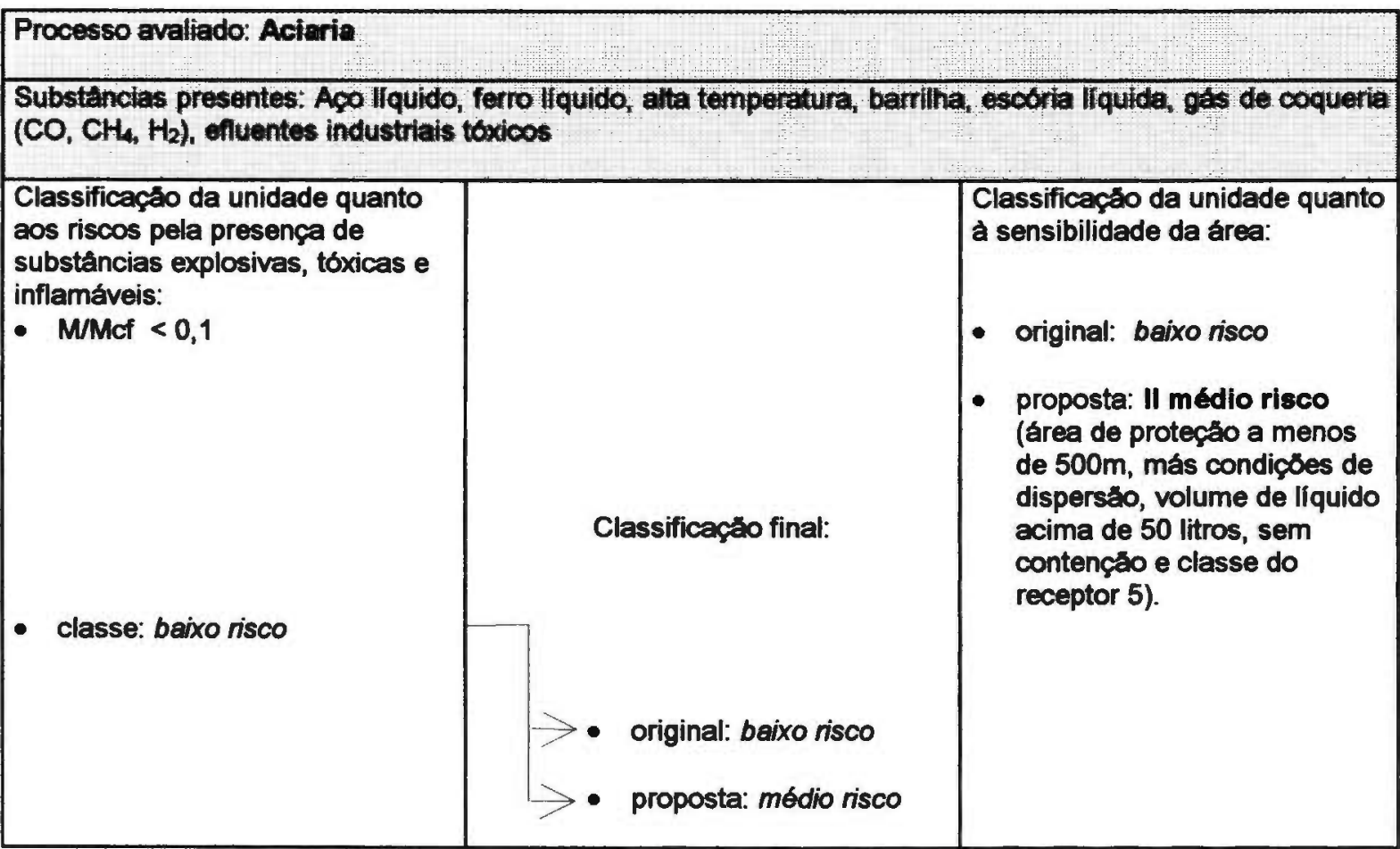


Figura 31. Classe de risco segundo CATBRAS modificada para: lingotamento contínuo

\begin{tabular}{|c|c|c|c|c|c|}
\hline \multicolumn{6}{|c|}{ Processo avaliado Lingotamento coníinuo } \\
\hline \multicolumn{6}{|c|}{$\begin{array}{l}\left.\text { Substancias presentes: Aco liquido, bleo lubrificante, gés de coqueria( } \mathrm{CO}, \mathrm{CH}_{4}, \mathrm{H}_{2}\right) \text {, nitrogénio, argónio, } \\
\text { GLP gás liquefeito de petroleo (CH4) }\end{array}$} \\
\hline Evento & MTMer $>10$ ? & MMAcF $>0.1 ?$ & $\begin{array}{l}\text { Contencao ou } \\
\text { impermeabilizasao }\end{array}$ & $\begin{array}{l}\text { Classificacto } \\
\text { amblental }=\mathrm{A} \text { ? }\end{array}$ & $\begin{array}{l}\text { Classe } \\
\text { de risco }\end{array}$ \\
\hline \multicolumn{6}{|l|}{ Óleo } \\
\hline \multirow[t]{3}{*}{ Meio: água } & não & & & & \multirow{3}{*}{ II } \\
\hline & & não & & & \\
\hline & & & não & $\overline{\operatorname{Sim}}$ & \\
\hline
\end{tabular}

Figura 31A. Classe de risco final para: lingotamento contínuo

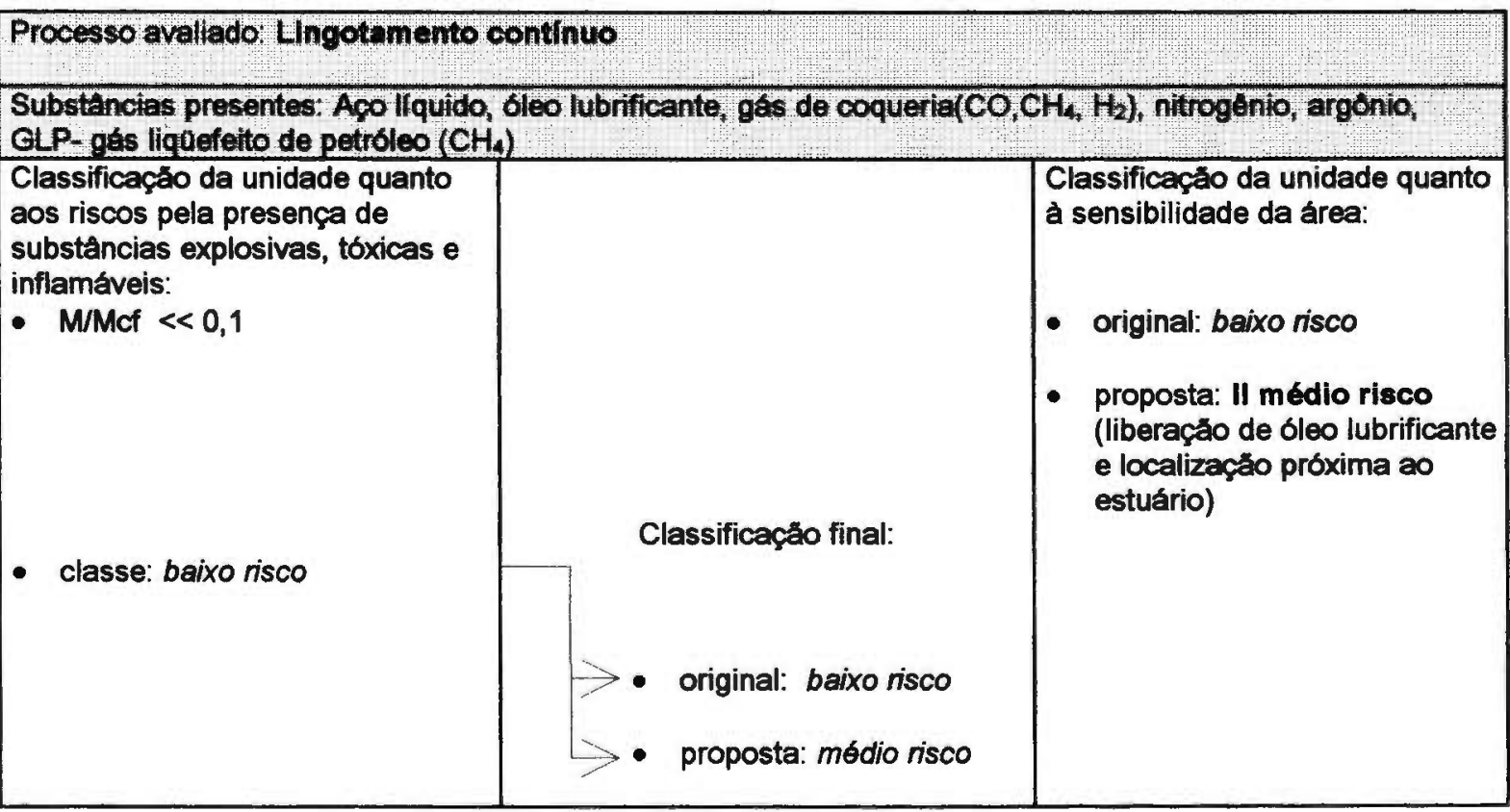


Figura 32. Classe de risco segundo CATBRAS modificada para: Laminação de tiras a quente

\begin{tabular}{|c|c|c|c|c|c|}
\hline \multicolumn{6}{|c|}{ Processo avaliado: Laminackio de tiras a quente (LTC) } \\
\hline \multicolumn{6}{|c|}{$\begin{array}{l}\left.\text { Substanclas presentes: Gás de coqueria (CO, } \mathrm{CH}_{4}, \mathrm{H}_{2}\right) \text {, oleo combustivel (BTE - } 1 \mathrm{~A}-\text { baixo teor de enxofre), } \\
\text { oleo lubrificante }\end{array}$} \\
\hline Evento & $\mathrm{M}^{\prime} \mathrm{M}_{\mathrm{Cr}}>10$ ? & $M M_{C}>0.1 ?$ & $\begin{array}{l}\text { Contençào ou } \\
\text { impermeabilizaça }\end{array}$ & Classificacáo & $\begin{array}{l}\text { Classe de } \\
\text { risce }\end{array}$ \\
\hline Óleo & não & \multirow{2}{*}{$\operatorname{sim}$} & não & \multirow[t]{2}{*}{$\operatorname{sim}$} & \\
\hline Meio: água & & & & & \\
\hline
\end{tabular}

Figura 32A. Classe de risco final para: laminaçăo de tiras a quente (LTQ)

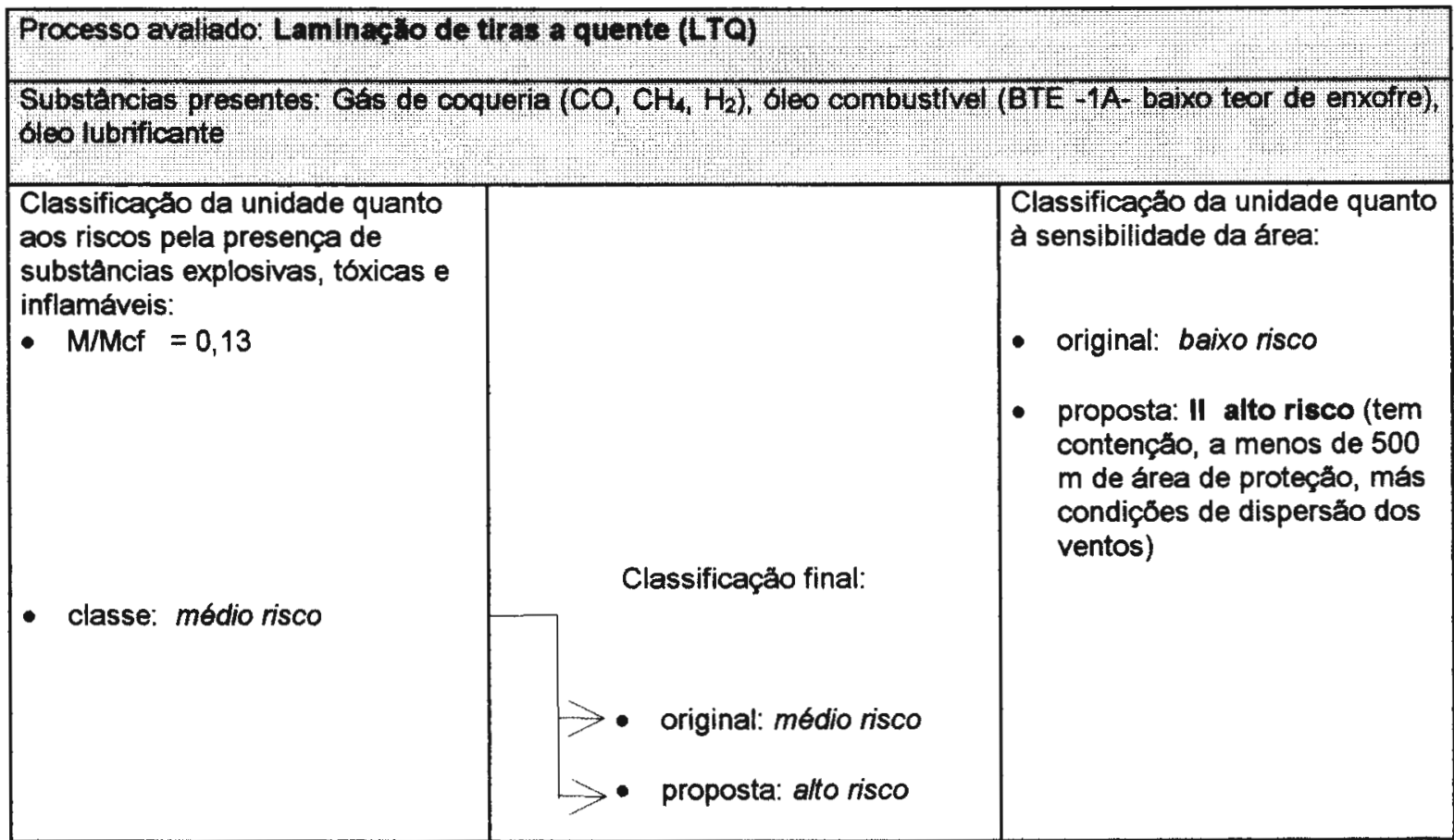


Figura 33. Classe de risco segundo CATBRAS modificada para: laminação de tiras a frio

\begin{tabular}{|c|c|c|c|c|c|}
\hline \multicolumn{6}{|c|}{ Processo avaliado: Laminaçâo de tiras a frio (LTF) } \\
\hline \multicolumn{6}{|c|}{ Substâncias presentes: Amónia, gás de coqueria $\left(\mathrm{CO}_{1} \mathrm{CH}_{4}, \mathrm{H}_{2}\right)$, oleos lubrificantes } \\
\hline Evento & $M^{\prime} / M_{C F}>1.0 ?$ & $M^{\prime} M_{C F}>0.1 ?$ & $\begin{array}{l}\text { Tem Contencto ou } \\
\text { impermeabilizaço ? }\end{array}$ & $\begin{array}{c}\text { Classificaçăo } \\
\text { ambiental = A ? }\end{array}$ & $\begin{array}{l}\text { Classe de } \\
\text { risco }\end{array}$ \\
\hline Amônia & não & $\overline{\operatorname{sim}}$ & não & sim & \\
\hline Meio: ar & & & & $V$ & \\
\hline
\end{tabular}

Figura 33A. Classe de risco final para: laminação de tiras a frio (LTF)

\begin{tabular}{|c|c|c|}
\hline \multicolumn{3}{|c|}{ Processo avaliado: Laminaçăo de tiras a frio (LTf) } \\
\hline Substancias presentes: Amónia, 8 & fia $\left(\mathrm{CO}_{3} \mathrm{CH}_{4}, \mathrm{H}_{2}\right)$, oleos & cantes \\
\hline $\begin{array}{l}\text { Classificaçăo da unidade quanto } \\
\text { aos riscos pela presença de } \\
\text { substáncias explosivas, tóxicas e } \\
\text { inflamáveis: } \\
\text { - M/Mcf }=0,166 \\
\text { - classe: médio risco }\end{array}$ & $\begin{array}{l}\text { Classificaçăo final: } \\
\rightarrow \text { original: médio risco } \\
\rightarrow \text { • proposta: alto risco }\end{array}$ & $\begin{array}{l}\text { Classificaçáo da unidade quanto } \\
\text { a sensibilidade da área: } \\
\text { - original: médio risco } \\
\text { - proposta: I alto risco } \\
\text { (sem contençáo (gases), } \\
\text { área de trânsito a menos de } \\
500 \text { m, más condiçóes de } \\
\text { dispersão dos ventos, } \\
\text { tanque sem contençáo } \\
\text { (líquido), volume acima de } \\
50 \text { litros, classe do receptor - } \\
5 \text { ) }\end{array}$ \\
\hline
\end{tabular}


Figura 34. Classe de risco segundo CATBRAS modificada para: dessulfuração

\begin{tabular}{|c|c|c|c|c|c|}
\hline \multicolumn{6}{|c|}{ Processo avaliado: Dessulfuraçăo } \\
\hline \multicolumn{6}{|c|}{ Substáncias presentes: Carbeto de cálcio, ferro llquido, acetileno, subproduto controlado, nitrogénio } \\
\hline Evento & MAM & $M / M_{C F}>0.1 ?$ & $\begin{array}{l}\text { Tem Contenção ou } \\
\text { impermeabilizaçáo? }\end{array}$ & $\begin{array}{l}\text { Classificaçáo } \\
\text { ambiental }=\mathrm{A} \text { ? }\end{array}$ & $\begin{array}{l}\text { Classe de } \\
\text { risco }\end{array}$ \\
\hline & \multicolumn{2}{|l|}{ não } & & & \multirow[t]{3}{*}{ II } \\
\hline $\begin{array}{l}\text { Produtos } \\
\text { químicos }\end{array}$ & & & não & \multirow[t]{2}{*}{$\operatorname{sim}$} & \\
\hline Meio: água & & & & & \\
\hline
\end{tabular}

Figura 34A. Classe de risco final para: dessulfuração

\begin{tabular}{|c|c|c|}
\hline \multicolumn{3}{|c|}{ Processo avaliado: Dessulfuraçăo } \\
\hline \multicolumn{3}{|c|}{$\begin{array}{l}\text { Processo avaliado: Dessulfuraça } \\
\text { Substancias presentes: Carbeto de cálcio, ferro liquido, acetileno, subproduto controlado, nitrogénio }\end{array}$} \\
\hline $\begin{array}{l}\text { Classificaçăo da unidade quanto } \\
\text { aos riscos pela presença de } \\
\text { substâncias explosivas, tóxicas e } \\
\text { inflamáveis: } \\
\text { - M/Mcf }<<0,1 \\
\text { - classe: baixo risco }\end{array}$ & $\begin{array}{l}\text { Classificaçăo final: } \\
\text { original: médio risco } \\
\text { proposta: médio risco }\end{array}$ & $\begin{array}{l}\text { Classificaçăo da unidade quanto } \\
\text { à sensibilidade da área: } \\
\text { - original: médio risco } \\
\text { - proposta: Il médio risco } \\
\text { (área de tránsito intenso a } \\
\text { menos de } 500 \text { m, más } \\
\text { condiçő́es de dispersão) }\end{array}$ \\
\hline
\end{tabular}


Figura 35. Classe de risco segundo CATBRAS modificada para: fábrica de oxigênio

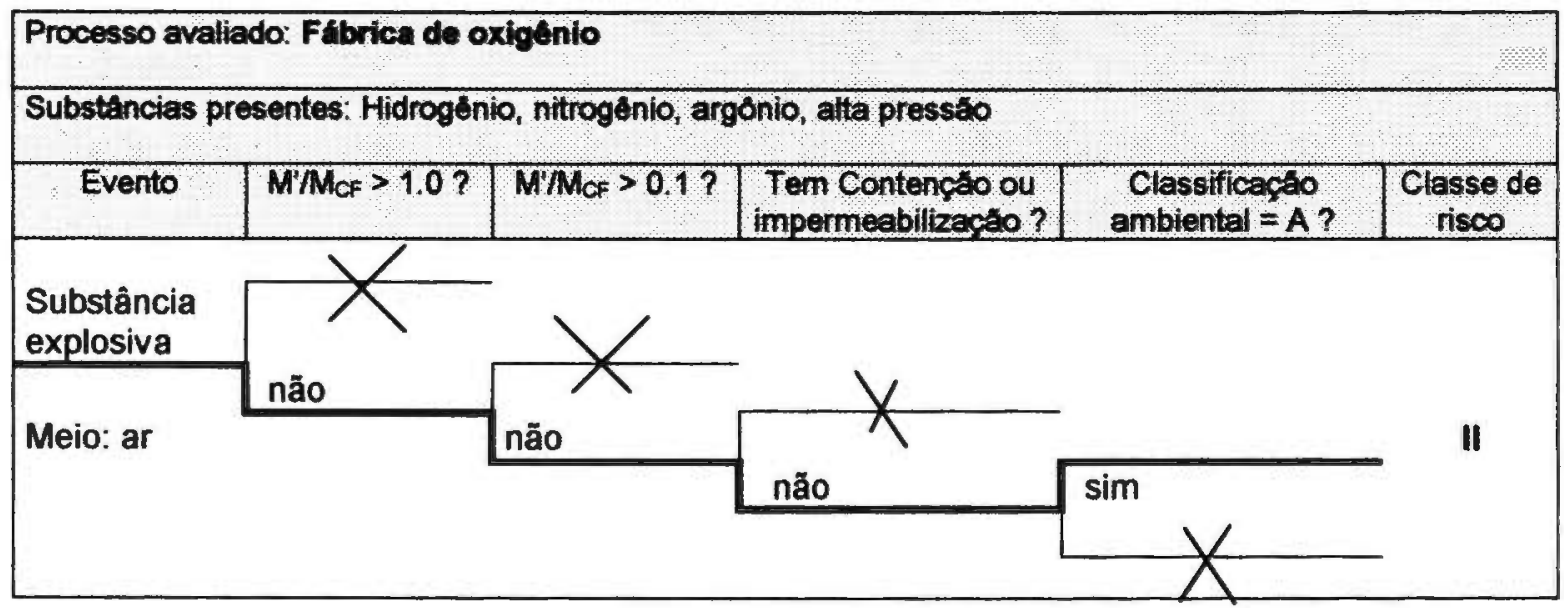

Figura 35A. Classe de risco final para: fábrica de oxigênio

\begin{tabular}{|c|c|c|}
\hline \multicolumn{3}{|c|}{ Processo avaliado: Fibrica de oxigénlo } \\
\hline Substancias presentes: Hidrogenti & nitrogénio, argónio, alta press to & \\
\hline $\begin{array}{l}\text { Classificaçáo da unidade quanto } \\
\text { aos riscos pela presença de } \\
\text { substáncias explosivas, tóxicas e } \\
\text { inflamáveis: } \\
\text { - M/Mcf <0,1 } \\
\text { - classe: baixo risco }\end{array}$ & $>$ original: médio risco & $\begin{array}{l}\text { Classificaçá da unidade quanto } \\
\text { à sensibilidade da área: } \\
\text { - Original: módio risco } \\
\text { - Proposta: II médio risco } \\
\text { (substância nåo tóxicas) }\end{array}$ \\
\hline
\end{tabular}

A determinaçăo da Categoria de Risco dos setores acima, comparando o resultado obtido pela classificaçăo da unidade quanto à sensibilidade da área original e a proposta, apresenta variaçōes profundas, que alteram inclusive a classificaçăo final da unidade, quando são considerados os riscos relativos ao processo e à sensibilidade da área.

Na tabela 24 săo apresentados os resultados da comparaçăo entre os dois métodos.

Observa-se que a proposta, por incluir danos ao meio ambiente, altera a classificação final das unidades, transformando-as em classe de risco médio ou atto, e, em um caso, reduzindo o risco de médio para baixo risco. O fato evidencia que, ao se assumir a avaliaçăo do risco aos recursos naturais e à biota próximos às unidades de produção, há automaticamente uma nova 
Tabela 24. Comparação dos resultados obtidos entre a APR original e a APR-A proposta, para a usina siderúrgica considerada

\begin{tabular}{l|c|c|c|c}
\hline \multirow{2}{*}{ Classe de risco } & \multicolumn{2}{|c|}{ Sensibilidade ambiental } & \multicolumn{2}{c}{ Classificaçá final } \\
\cline { 2 - 5 } & original & proposta & original & proposta \\
\hline Baixo & 4 & - & 2 & - \\
Médio & 4 & 6 & 6 & 5 \\
Alto & 3 & 5 & 3 & 6 \\
\hline
\end{tabular}

classificação dessas unidades. Essa ordenação permitirá ao técnico ter uma visão mais clara dos meios a serem protegidos, não se detendo a avaliar somente a quantidade de substância presente ou a sua toxicidade, explosividade ou inflamabilidade; ele deverá também considerar que um vazamento desses produtos ou de outros poderá causar danos aos meios conforme definidos neste trabalho.

\subsubsection{Definição das hipóteses de acidentes}

Após a identificação e classificação das unidades que apresentam riscos maiores de acidentes que possam provocar danos ao meio ambiente, saúde humana e patrimoniais, o próximo passo na análise de risco é definir as hipóteses de acidentes para cada uma das unidades que apresentarem riscos médios e/ou altos. O critério de escolha das unidades que devem ser analisadas prioritariamente deve levar em conta a classificação obtida. No caso de serem encontradas várias unidades dentro de uma classe de risco (por exemplo, alto), a prioridade pode ser definida pelo índice da relação $M^{\prime} / M_{c f}$, iniciando pelas atividades com maior índice da relação massa corrigida ( $\left.M^{\prime}\right)$ e massa critica final $\left(M_{C f}\right)$. Se os valores comparados forem relativamente próximos, recomenda-se observar a classificação da unidade quanto à sensibilidade da área, decidindo-se pela que revelar maior risco.

O procedimento para execução da APR-A deve começar com uma seleção dos acidentes/incidentes já ocorridos na unidade em análise. Essa etapa pode ser realizada a partir de relatos de experiências já vividas no setor, relatórios da área de Segurança do Trabalho, ou banco de dados, local ou não. Esse estágio consiste da identificação dos riscos, perigos, eventos iniciadores/base em potencial e outros eventos capazes de redundar em efeitos indesejáveis. Evidentemente, exige-se dos participantes da APR-A uma certa experiência, para obter tais dados.

Para a realização desta aplicação prática da APR-A, partiu-se da seguinte ordenação das identificaçōes de riscos promovidas na empresa tomada como exemplo, conforme apresentado na tabela 25.

Tabela 25. Priorização das unidades frente à classe de risco identificada na usina siderúrgica considerada

\begin{tabular}{l|c|c|c|c|c}
\hline \multirow{2}{*}{ Unidade } & \multicolumn{3}{c|}{ Classíficacão } & Prioridade \\
\cline { 2 - 5 } & Processo & Amblental & Final & M'M & \\
\hline coqueria & alto & alto & alto & 2,6 & 2 \\
carboquímicos & alto & alto & alto & 4,8 & 1 \\
alto-forno & médio & alto & alto & 3,1 & 3 \\
aciaria & baixo & médio & médio & $<0,1$ & 7 \\
lingotamento contínuo & baixo & médio & médio & $<<0,1$ & 10 \\
LTF & médio & alto & alto & 0,166 & 4 \\
sinterização & baixo & médio & médio & $<<0,1$ & 11 \\
calcinação & médio & médio & médio & 0,145 & 6 \\
LTQ & médio & alto & alto & 0,13 & 5 \\
dessulfuração & baixo & médio & médio & $<<0,1$ & 9 \\
fábrica de oxigênio & baixo & médio & médio & $<0,1$ & 8 \\
\hline
\end{tabular}


Nessa tabela, a unidade carboquímicos configurou-se como de alto risco, tanto para o processo quanto para a sensibilidade ambiental. Da mesma maneira, a unidade de coqueria configurou-se como de alto risco, pelos mesmos critérios. Como proposto anteriormente, o critério de desempate foi o índice de exposição devido às massas presentes de substâncias perigosas. Nesse caso, a unidade Carboquímicos apresentou índice 4,8 - superior, portanto, ao índice indicado para a coqueria, que é de 2,6 .

Essa definição pode, e deve, ser confirmada através de consultas a bancos de dados de acidentes industriais, selecionando o setor de interesse. Com os dados obtidos do banco, faz-se uma estratificação dos resultados e identificam-se os processos que geraram maior quantidade de acidentes em um intervalo de tempo. A consulta ao banco de dados SONATA confirmou que a unidade com registro de maior número de acidentes (ambientais, segurança e saúde humanas e patrimoniais) é a de carboquímicos. A avaliação dos resultados obtidos no banco de dados e a classificação efetuada dão ao técnico a segurança para desenvolver seu trabalho. Vale ressaltar, entretanto, que usar unicamente o banco de dados pode induzir o técnico a erros, pois nem sempre os bancos de dados trazem as informações de forma precisa e direta.

Definida a ordem de prioridade ou o grau de risco das unidades envolvidas no processo siderúrgico, o próximo passo consiste em definir quais as hipóteses de acidentes que estão presentes nas operações ou sistemas estudados.

A aplicação da APR-A no estudo do risco da unidade Carboquímicos fica evidenciada pela priorizaçăo obtida anteriormente. Para a execução da APR-A nessa unidade, deve-se levar em conta o seu porte e os vários subsistemas presentes, além das substâncias usadas ou produzidas, as interfaces entre equipamentos e materiais, fatores ambientais que podem iniciar os eventos negativos, procedimentos operacionais, armazenamentos temporários (ou não) de produtos e substâncias perigosas, e os equipamentos auxiliares de segurança e de proteção ambiental. Esses fatores somados levam à efetivação de um estudo relativamente complexo. $O$ objetivo deste trabalho é evidenciar a aplicabilidade da técnica na definição dos acidentes ambientais, não se preocupando em realizar um estudo completo de uma unidade. Portanto, a APR-A da unidade Carboquímicos ficará restrita a alguns poucos exemplos de riscos identificados através dos bancos de dados consultados e da experiência prática do autor. As figuras 36 a 40 representam o resultado da análise preliminar de risco ambiental para os sistemas selecionados como exemplo de aplicação prática.

A aplicação seguiu a técnica original da MIL-STD-882A modificada, segundo proposta deste trabalho, abrangendo as variáveis ambientais conforme já comentado.

O primeiro passo para estabelecer um cenário representativo de um evento é conhecer os componentes do sistema que está sendo avaliado. Embora os procedimentos, operações e quantidade de instrumentos, equipamentos, dutos, vasos, etc., sejam muitos e variados no porte e constituição, existe, na realidade, um número relativamente pequeno de diferentes tipos de componentes que são importantes na análise de riscos de um sistema. As funções principais desses componentes são limitadas a dez casos genéricos, porém de grande implicação nos históricos de acidentes industriais.

A tabela 26 contém os dez principais componentes de um processo industrial ou atividade, que, historicamente, representam riscos de acidentes e que devem ser avaliados. Na mesma tabela estão relacionadas as principais falhas típicas desses elementos e a variação estimada da dimensão dessas falhas. 
Tabela 26. Principais componentes do processo industrial e estimativa de falhas (seg. KAYES, 1985, modificada). Vaz.: vazamento

\begin{tabular}{|c|c|c|}
\hline Componentes & $\begin{array}{c}\text { Falhas tipicas } \\
\text { (vazamento, falha ou ruptura) }\end{array}$ & $\begin{array}{c}\text { Vazamento esperado } \\
(\%)^{*}\end{array}$ \\
\hline Tubulações & $\begin{array}{l}\text { 1. vaz. no flange } \\
\text { 2. vaz. na tubulação } \\
\text { 3. falha na solda }\end{array}$ & $\begin{array}{l}\text { 1. } 20 \\
\text { 2. de } 20 \text { a } 100 \\
\text { 3. de } 20 \text { a } 100\end{array}$ \\
\hline Conexōes flexiveis & $\begin{array}{l}\text { 4. ruptura } \\
\text { 5. vaz. na conexão } \\
\text { 6. falha na conexão (mecânica) }\end{array}$ & $\begin{array}{ll}\text { 4. } & 100 \\
\text { 5. } 20 \\
\text { 6. } 100\end{array}$ \\
\hline Filtros & $\begin{array}{l}\text { 7. vaz. no corpo } \\
\text { 8. vaz. na cobertura }\end{array}$ & $\begin{array}{l}\text { 7. de } 20 \text { a } 100 \\
\text { 8. } 20\end{array}$ \\
\hline Válvulas & $\begin{array}{l}\text { 9. vaz. no corpo } \\
\text { 10. vaz. pela cobertura (tampa) } \\
\text { 11. vaz. pela haste }\end{array}$ & $\begin{array}{l}\text { 9. } 20 \text { a } 100 \\
\text { 10. } 20 \\
\text { 11. } 20\end{array}$ \\
\hline $\begin{array}{l}\text { Vasos de pressão ou } \\
\text { processo }\end{array}$ & $\begin{array}{l}\text { 12. ruptura do vaso } \\
\text { 13. vaz. pela janela de visita } \\
\text { 14. falha no bocal } \\
\text { 15. falha dos instrumentos } \\
\text { 16. explosão interna }\end{array}$ & $\begin{array}{l}\text { 12. total } \\
\text { 13. } 20 \\
\text { 14. } 100 \\
\text { 15. } 20 \text { a } 100 \% \text { da linha } \\
\text { 16. total }\end{array}$ \\
\hline Bombas & $\begin{array}{l}\text { 17. falha no corpo } \\
\text { 18. vaz. na gaxeta }\end{array}$ & $\begin{array}{l}\text { 17. } 20 \text { a } 100 \\
\text { 18. } 20\end{array}$ \\
\hline Compressores & $\begin{array}{l}\text { 19. falha no corpo } \\
\text { 20. vaz. na gaxeta }\end{array}$ & $\begin{array}{l}\text { 19. } 20 \text { a } 100 \\
20.20\end{array}$ \\
\hline Tanques de estocagem & $\begin{array}{l}\text { 21. falha do tanque } \\
\text { 22. vaz. nas conexões }\end{array}$ & 21. total 20 a 100 \\
\hline Vasos de estocagem & $\begin{array}{l}\text { 23. BLEVE } \\
\text { 24. ruptura } \\
\text { 25. vaz. nas conexões }\end{array}$ & $\begin{array}{l}\text { 23. total } \\
\text { 24. total } \\
\text { 25. } 20 \text { a } 100\end{array}$ \\
\hline Flare/Vents/Chaminés & $\begin{array}{l}\text { 26. vaz. nos manifolds } \\
\text { 27. descangas fora de especificacão }\end{array}$ & $\begin{array}{l}\text { 26. } 20 \text { a } 100 \\
\text { 27. a ser estimado }\end{array}$ \\
\hline
\end{tabular}

(") refere-se ao vazamento de produto que poderá ocorrer se a falha acontecer. O valor é dado em porcentagem de produto em funçăo da área correspondente da falha. Por exemplo, a área de um flange corresponde a $20 \%$ da área de uma tubulaçăo em um determinado segmento, e a falha na solda pode corresponder até à ruptura total (100\%) de uma tubulação qualquer. 
Figura 36. Analise Preliminar de Risco Ambiental - APR-A (gasómetros- gases de coqueria)

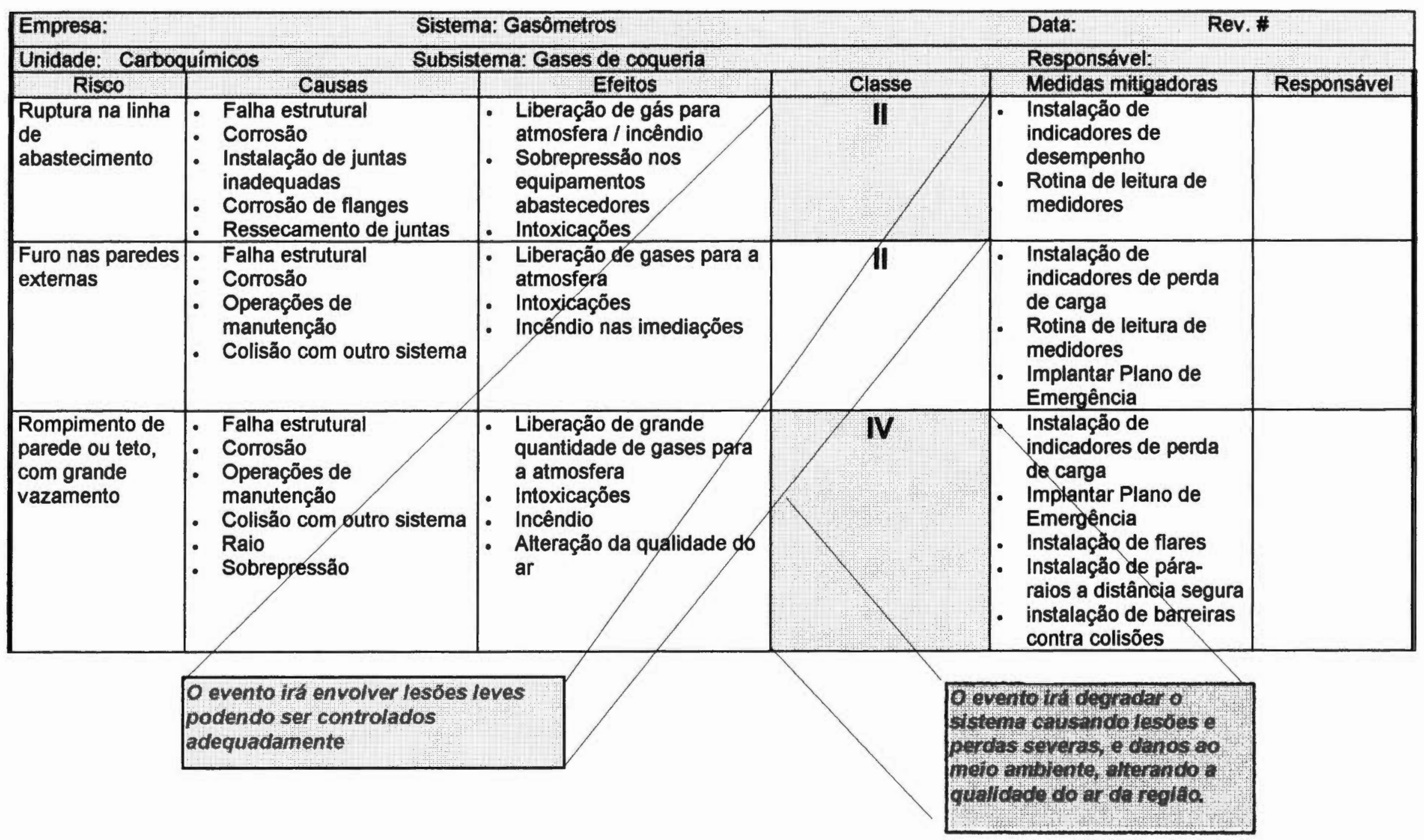


Figura 37. Análise Preliminar de Risco Ambiental - APR-A (tratamento de amónia - coluna de "stripping")

\begin{tabular}{|c|c|c|c|c|c|}
\hline Empresa: & Sistem & a: Tratamento de amônia & & Rev. & \\
\hline Unidade: Carbog & Subsis & tema: Coluna de "stripping" & & Responsável: & \\
\hline Risco & Causas & Eleilos & Classe & Medidas mitigadoras & Responsável \\
\hline $\begin{array}{l}\text { Vazamento de } \\
\text { licor na junta de } \\
\text { entrada }\end{array}$ & $\begin{array}{l}\text { - Desgaste da junta } \\
\text { - Falha de montagem } \\
\text { - Erro de manutenção } \\
\text { - Sobrecarga no sistema }\end{array}$ & $\begin{array}{l}\text { - Vazamento para galeria } \\
\text { e águas superficiais (rios } \\
\text { e estuário) } \\
\text { - Contaminação do solo } \\
\text { - Intoxicação } \\
\text { - } \quad \text { Queimaduras químicas }\end{array}$ & & $\begin{array}{l}\text { Programa de manutenção } \\
\text { preventiva } \\
\text { Instalar sistemas de } \\
\text { detecção de pressão na } \\
\text { rede } \\
\text { Implantar Plano de } \\
\text { Emergência Ambiental } \\
\text { Instalar contenção } \\
\text { secundária }\end{array}$ & \\
\hline $\begin{array}{l}\text { Emissão de } \\
\text { vapores de } \\
\text { amônia }\end{array}$ & $\begin{array}{l}\text { Falha nos pratos de } \\
\text { condensação } \\
\text { - Excesso de licor no } \\
\text { sistema } \\
\text { - Falha na refrigeração }\end{array}$ & $\begin{array}{l}\text { - Emissão de vapores } \\
\text { tóxicos } \\
\text { - Intoxicações } \\
\text { - Corrosão de materiais e } \\
\text { equipamentos } \\
\text { - Comprometimento do } \\
\text { incinerador }\end{array}$ & & 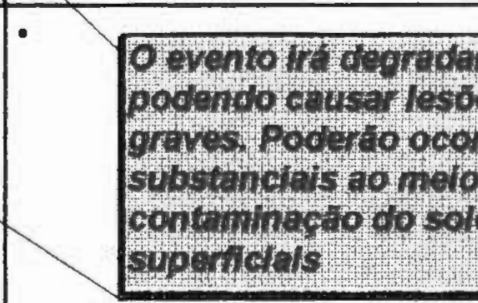 & 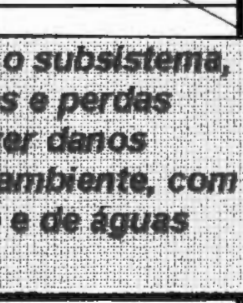 \\
\hline $\begin{array}{l}\text { Explosão do } \\
\text { subsistema }\end{array}$ & $\begin{array}{l}\text { - Falha no sistema de } \\
\text { refrigeração } \\
\text { - Sobrepressão interna } \\
\text { - Falha do sistema de alívio } \\
\text { - Falha no sistema de } \\
\text { alimentação do } \\
\text { incinerador }\end{array}$ & $\begin{array}{l}\text { - Formação de nuvem } \\
\text { tóxica } \\
\text { - Severa degradação do } \\
\text { subsistema } \\
\text { - Intoxicações } \\
\text { - Lesőes graves/mortes } \\
\text { - danos ambientais } \\
\text { severos }\end{array}$ & & $\begin{array}{l}\text { Programa de manutenção } \\
\text { preventiva } \\
\text { Instałar sistema de } \\
\text { controle de pressão } \\
\text { interna } \\
\text { Instalar sistema de } \\
\text { controle de temperatura } \\
\text { de refrigeração } \\
\text { Implantar Plano de } \\
\text { Emergência }\end{array}$ & \\
\hline & & & & $\begin{array}{l}\text { O evento produzirá sever } \\
\text { do sistema, podendo caut } \\
\text { lesóes graves ou mortes. } \\
\text { risco de severos danos } \\
\text { ambientais, causando mo } \\
\text { fauma aquática. }\end{array}$ & $\begin{array}{l}\text { perda } \\
\text { ar } \\
\text { la } 0\end{array}$ \\
\hline
\end{tabular}


Figura 38. Análise Preliminar de Risco Ambiental - APR-A (tanque de alcatrăo - carregamento)

\begin{tabular}{|c|c|c|c|c|c|}
\hline Empresa: & Sistem 8 & : Tanque de alcatráo & & Data: & \\
\hline $\begin{array}{l}\text { Vazamento de } \\
\text { líquidos e gases }\end{array}$ & \begin{tabular}{|l} 
- Aumento de pressão no \\
carregamento \\
- Rompimento de mangotes \\
- Engates ou conexões mal \\
colocadas ou inadequadas \\
- Saída do caminhão sem \\
autorização \\
- Ultrapassar a capacidade \\
do tanque do caminhão \\
- Colisão do caminhão com \\
o tanque de \\
abastecimento
\end{tabular} & $\begin{array}{l}\text { - Vazamento para galerias ga } \\
\text { águas superficiais } \\
\text { - } \text { Contaminação do solo } \\
\text { - Intoxicaçőes } \\
\text { - Queimaduras químicas } \\
\text { - Panos materiais } \\
\end{array}$ & || & $\begin{array}{l}\text { - Treinamento dos } \\
\text { operadores } \\
\text { - Manutenção preventiva } \\
\text { em engates e } \\
\text { mangotes } \\
\text { - Treinamento de } \\
\text { motoristas } \\
\text { - Instalar contenção } \\
\text { secundária } \\
\text { - Instalar proteção dos } \\
\text { tanques } \\
\text { - Uso de EPI } \\
\text { - Instalar bombas de } \\
\text { recalque na contenção } \\
\text { secundária } \\
\text { - Implantar Plano de } \\
\text { Emergência }\end{array}$ & \\
\hline
\end{tabular}


Figura 39. Análise Preliminar de Risco Ambiental - APR-A (tancagem - tanque de óleos leves)

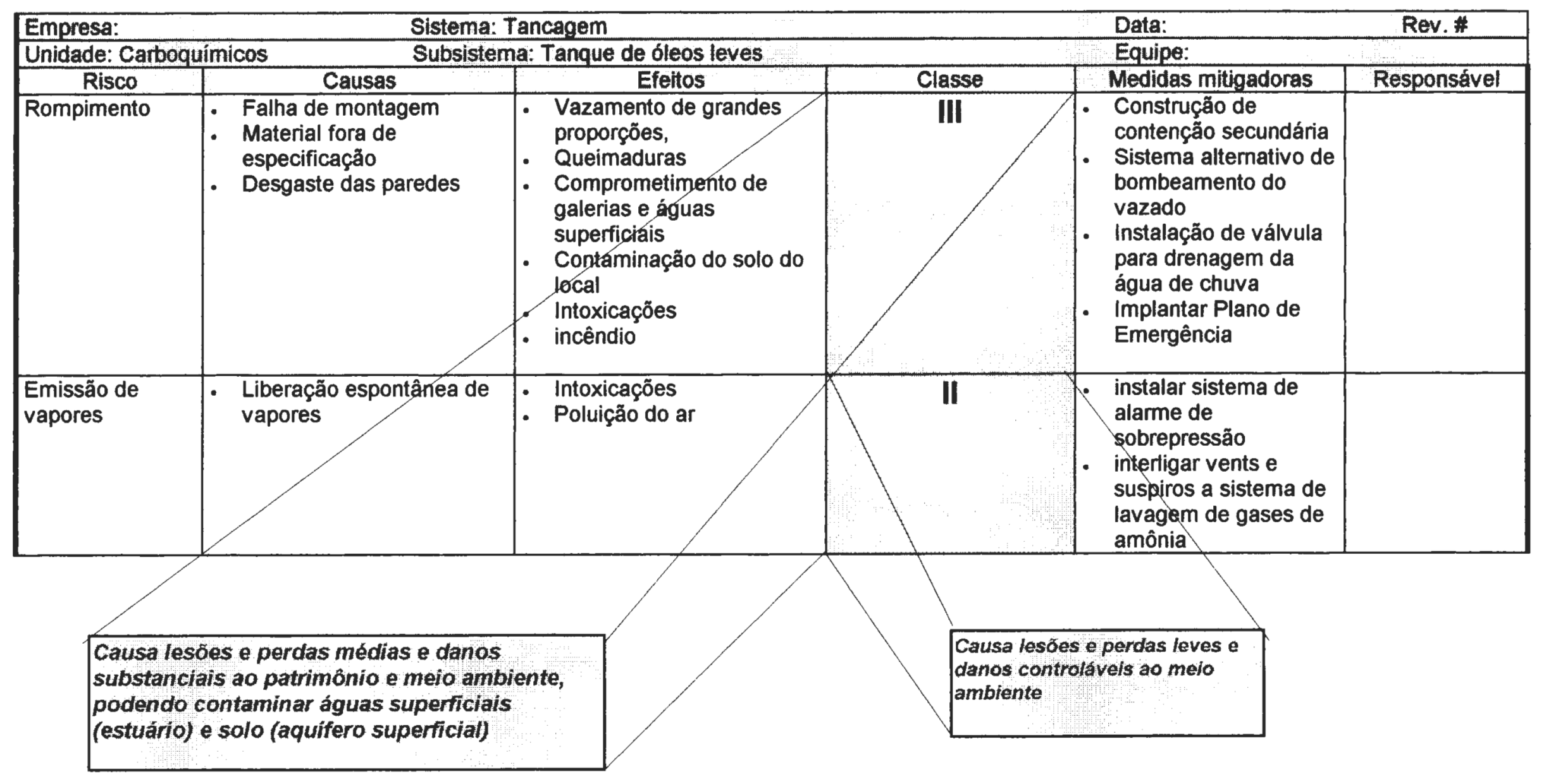




\section{Figura 40. Análise Preliminar de Risco Ambiental - APR-A (tancagem - tanque de licor de amónla)}

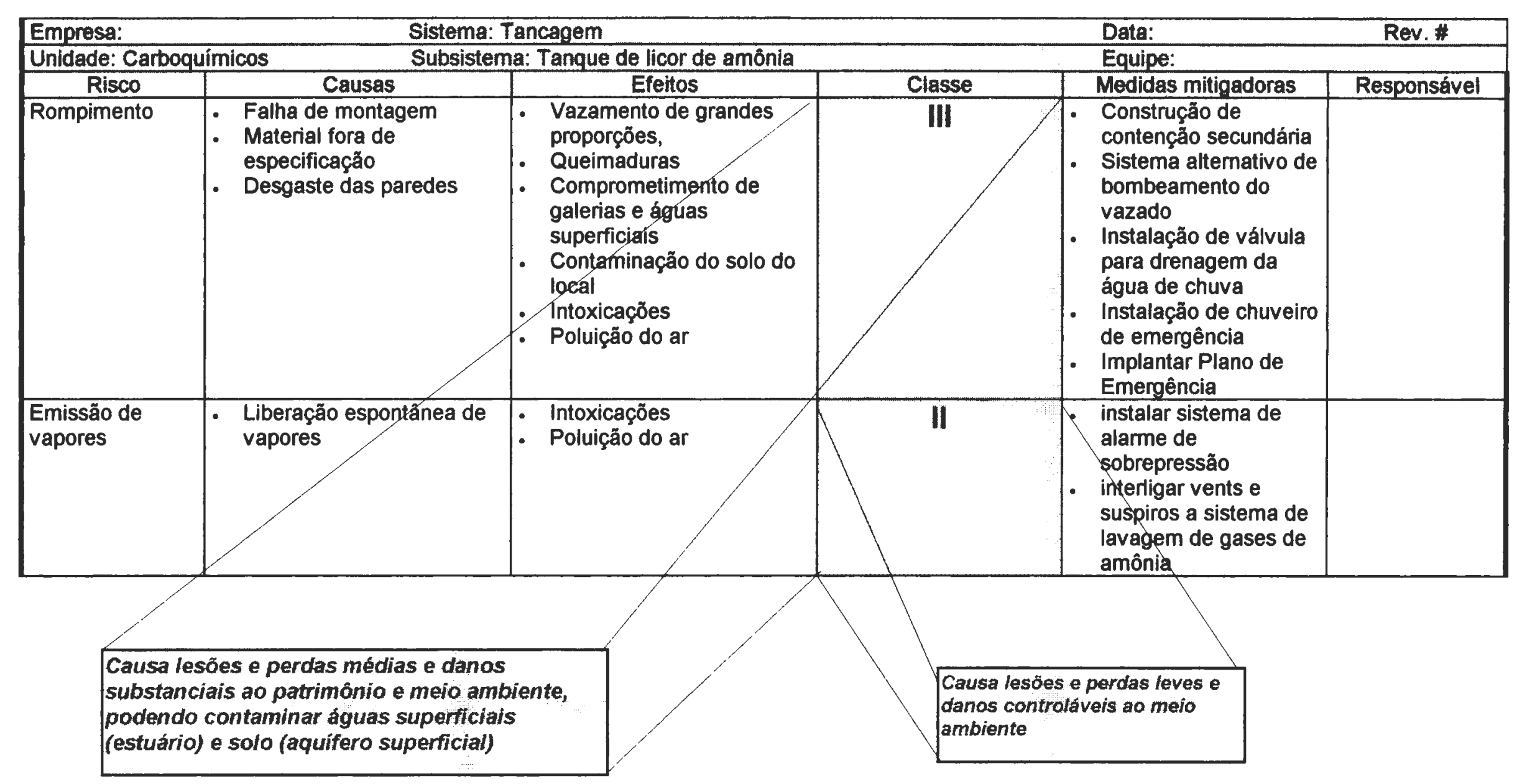




\subsubsection{Avaliação das hipóteses de acidentes definidas}

Através dos processos de análise de risco ambiental, foi possível identificar o grau de risco de uma usina siderúrgica integrada a coque e determinar as unidades que apresentam maior risco de acidentes envolvendo casos de incêndio, explosão e liberação de substâncias perigosas. A partir desses dados, definiram-se quais as prioridades de estudo deveriam ser atribuídas às unidades, em função do seu grau de risco. Segundo o estudo realizado, a unidade de Carboquímicos apresentou maior grau de risco de acidentes com consequências ambientais e também para a saúde humana e à propriedade. Essa informação, fundamentada em conceitos definidos tecnicamente, permitiu a definição das hipóteses de acidentes encontradas nas unidades avaliadas.

A definição dessas hipóteses de acidentes foi feita através da Análise Preliminar de Risco Ambiental (APR-A), conforme técnica proposta neste trabalho. A aplicação da APR-A a alguns subsistemas da unidade de Carboquímicos, conforme previsto anteriormente, visto que este trabalho não objetiva a avaliação da unidade, permitiu identificar vários riscos que apresentam Categoria de Risco III ou IV, isto é: Crítico ou Catastrofico.

Ainda para efeito de aplicação prática da proposta de aprimoramento das técnicas de análise de risco, e ampliando seu escopo para atender à variável meio ambiente, foram selecionados os acidentes definidos como de maior dano (Categorias III e IV) pela APR-A elaborada.

O resultado da aplicação da APR-A na unidade de carboquímicos mostra que a unidade é composta por vários sistemas que apresentam riscos, variando de limitrofes a catastróficos. Em alguns casos, essa variação é obtida em um subsistema, como é o caso dos tanques de gases de coqueria (25.000 e $100.000 \mathrm{~m}^{3}$ de capacidade). A análise resulta ainda na identificação das causas e dos efeitos da realização do evento descrito. Porém, com a modificação proposta, fica evidenciado o efeito de um acidente sobre o meio ambiente. Com o desdobramento dos termos impacto ambiental e dano, foi possivel determinar com clareza e maior precisão os efeitos sobre 0 meio e definir com coerência a classe de risco que se atribui ao evento estudado.

Seguindo portanto as indicações da Figura 21, a AE-A para a unidade Carboquímicos e subsistemas analisados serão encontrados eventos com liberação de gases tóxicos e líquidos classificados também como tóxicos. Há ainda a identificação de eventos com explosão, que também serão considerados.

Para cada evento a ser avaliado foi desenvolvida uma $A E-A$ especifica. Essas AE-A estão representadas a seguir, baseadas nas $A E-A$ já estruturadas neste trabalho, para conter a variável ambiental. A avaliação, como nos casos anteriores, será feita considerando dados existentes e a experiência do autor na área siderúrgica, e principalmente deverá ser entendida como um exemplo prático de aplicação da técnica e não uma avaliação do sistema existente na empresa atualmente.

A cada subsistema em estudo foram formuladas as questões constantes da planilha determinada pelo tipo de substância que está sendo avaliada. As planilhas seguem o modelo das figuras 22 a 24. Para efeito de visualização gráfica do produto da aplicação da AE-A, cada planilha resultante foi desenvolvida com o uso de linhas mais espessas, para ressaltar qual o caminho definido pelas questões e situação encontradas no sistema. A linha definida no estudo leva a um algarismo, que é a referência para a descrição da conseqüência do evento selecionado para o meio ambiente, conforme pode ser verificado na tabela 23.

Para efeito de aplicação prática da AE-A no sistema Carboquímicos, foram selecionados os eventos relacionados na tabela 27.

O resultado dessa análise está representado nas figuras 41 a 44, com a indicação dos efeitos sobre o meio ambiente. A cada número contido no item efeito corresponde uma consequéncia, conforme descrito na tabela 23. 
Tabela 27. Relaçáo dos sistemas a serem submetidos à avaliaçăo das hipóteses de acidentes

\begin{tabular}{l|l|l|c}
\hline \multicolumn{1}{c|}{ Sistema } & \multicolumn{1}{|c|}{ Subsistema } & \multicolumn{1}{c|}{ Risco/Evento } & $\begin{array}{c}\text { Categoria de } \\
\text { risco }\end{array}$ \\
\hline $\begin{array}{l}\text { tratamento de licor } \\
\text { amoniacal }\end{array}$ & $\begin{array}{l}\text { coluna de } \\
\text { "stripping" }\end{array}$ & $\begin{array}{l}\text { explosão com liberação de gás } \\
\text { tóxico }\end{array}$ & IV \\
\hline $\begin{array}{l}\text { tratamento de licor } \\
\text { amoniacal }\end{array}$ & $\begin{array}{l}\text { coluna de } \\
\text { " stripping" }\end{array}$ & $\begin{array}{l}\text { explosão com liberação de líquido } \\
\text { perigoso }\end{array}$ & III \\
\hline gasômetros & $\begin{array}{l}\text { gases de } \\
\text { coqueria }\end{array}$ & $\begin{array}{l}\text { Rompimento com liberação de gás } \\
\text { inflamável }\end{array}$ & IV \\
\hline tancagem & $\begin{array}{l}\text { tanque de óleos } \\
\text { leves }\end{array}$ & $\begin{array}{l}\text { rompimento da conexão com } \\
\text { liberação de líquido perigoso }\end{array}$ & III \\
\hline
\end{tabular}

O primeiro exemplo de aplicação da AE-A refere-se à análise do sub-sistema "coluna de stripping" do tratamento de licor amoniacal do setor de Carboquímicos (Fig. 41). O evento considerado no exemplo foi a liberaçáo de gases tóxicos. Como explicado no item 3.5.3.1, o que se procura é responder, positiva ou negativamente, a cada pergunta constante no processo de análise. A utilização da figura é recomendada para análise do subsistema pois, conforme identificado na APR-A (Fig. 37), poderá haver a emissão de vapores de amônia, gerando um risco de classe IV.

Para a sua aplicação, a primeira questão é se a liberação é instantanea ou contínua. Sendo a resposta positiva, a linha decisória (mais espessa) segue para a próxima questão. A questão é se há formaçăo de nuvem densa; no exemplo dado, a resposta é negativa, levando a linha decisória para baixo, até a próxima questão. O subsistema analisado năo possui plano de emergéncia, desviando a linha espessa no sentido da próxima questão. Como a liberação de gases tóxicos pode atingir o ambiente interno/externo, os efeitos que poderão ser sentidos são descritos conforme 0 item 8 (oito) da tabela 23 ("Ocorrem danos severos e morte na população; restrição de uso temporário da região afetada; odores prejudiciais; perda de áreas cultivadas; restrição ao uso de meios de transporte; danos substanciais e severos à fauna/flora, morte de animais; perda de qualidade do ar"). Na elaboração da $A E-A$, para o exemplo dado, todas as demais linhas não precisam ser consideradas.

As mesmas explicações dadas para a obtenção da descrição dos riscos da liberaçăo de gases tóxicos, feita anteriormente, valem para o exemplo de liberaçăo de liquidos perigosos (Fig. 42), que pode ocorrer no subsistema "coluna de stripping de amônia". Nesse caso, é utilizada a Fig. 23. respondendo às questões formuladas no processo de análise. A primeira questão é respondida sabendo que o líquido vazado não sofre ignição. A linha decisória segue para a questão sobre se há ou não contenção secundária (a liberação do licor de amônia não provoca ondas de calor). Como não há contenção secundária, a linha espessa segue para baixo, em direção à questão sobre a geraçăo ou não de resíduos. Como a liberação de licor pode gerar resíduos e estes podem atingir diretamente o solo, o efeito descrito corresponde ao contido no item 6 da tabela 23. O efeito 6 prevê que "haverá contaminação do solo, com exigência de avaliação posterior da extensão da contaminaçăo, incluindo aqüiferos subterrâneos, e remediação do local. Poderá haver necessidade de incineração, ou outro processo, do solo contaminado; geraçăo de nuvens tóxicas e de odores prejudiciais, restrição de uso da área, restrição do uso da água subterrânea".

Já no exemplo dado na figura 43, para a ocorrência de liberação de uma substância inflamável contida no subsistema de coqueria, o caminho crítico a ser seguido é o mesmo dos exemplos anteriores. Como nesse exemplo ocorre a liberação instantânea de gás, por ruptura da tubulação, por exemplo, a linha crítica (mais espessa) segue para cima. Como no caso de uma ruptura a correção não é automática e não deve ocorrer a ignição, esses itens podem ser ignorados. A linha crítica vai então até a próxima questão, que é se há ou não formação de nuvem densa. Para o exemplo dado, a resposta é positiva, seguindo a linha para cima e em direção à nova questão. Como pode haver ignição retardada, ou não, há a possibilidade de a linha crítica tomar os dois caminhos. Se não houver a ignição retardada, a nuvem irá atingir os flares (pontos com fontes 
permanentes de ignição) e provocar a combustão do gás liberado. Caso positivo, ou seja, pode ocorrer ignição retardada, a próxima questão é sobre se podem ser formadas, ou não, ondas de calor. A resposta para o exemplo é positiva (linha crítica), levando à última questão, relativa à exposição do homem ou do meio ambiente. Como, no caso, o setor de armazenamento do gás está fora de uma área crítica, os efeitos referem-se ao item 2 da tabela 23 , descrito como "o incêndio ocorre com perda patrimonial e de produtos, possiveis danos à saúde humana; possibilidade de poluição das águas por produtos usados na extinção do incêndio".

Na figura 44, é apresentado o último exemplo de aplicação da AE-A para um processo siderúrgico. Nessa figura, é analisado o risco de liberaçăo de líquidos perigosos armazenados nos tanques de óleos leves, que poderia ocorrer durante o carregamento desses produtos. Como esse produto nåo sofre igniçăo, a linha crítica segue a linha negativa (para baixo). Por não haver ignição, não há necessidade de verificar se há, ou não, formação de ondas de calor. O processo de carregamento ocorre em setor que tem contenção secundária, direcionando a linha crítica para cima (sim) e em direção à nova questão. A liberação de óleos leves normaimente gera resíduos sólidos e semilíquidos. Portanto, a resposta deve ser positiva, levando a linha crítica para cima (sim). Como o setor tem contenção secundária, o líquido derramado deverá ficar retido nesse local, não atingindo solos, águas superficiais ou formando gás tóxico. Nesse caso, a análise é encerrada no item geraçăo de resíduos, indo diretamente para a definição do efeito ambiental. 0 efeito número 5 (tabela 23) define que a liberação de óleos leves durante o carregamento vai resultar em que "os resíduos gerados deverão ser dispostos adequadamente como Classe I e com autorização do órgão ambiental competente".

\subsubsection{CONSIDERAÇÕES}

A aplicação da análise de risco ambiental para avaliar os riscos existentes nos processos industriais e atividades mostra-se útil para a identificação e avaliação dos possiveis acidentes presentes nas atividades. Com a implantação das sugestões apresentadas neste trabalho, abordando a variável ambiental e os possíveis danos advindos dos acidentes, é possivel prever e propor formas de controle e mitigação para os eventos identificados.

A aplicação prática das técnicas propostas - CATBRAS, Análise Preliminar de Risco - Ambiental, e Análise por Árvore de Eventos - Ambiental, mostrou-se efetiva quando aplicada a uma usina de porte e que opera uma siderúrgica integrada a coque. Nesse sentido, foi possivel obter a classificação das principais unidades da empresa, fornecendo uma prioridade de ação quanto ao estudo de risco. Algumas unidades foram classificadas como sendo de atto risco, em função da sensibilidade ambiental, conforme considerada neste estudo. É o caso das unidades carboquímico e altos-fornos.

Essa prioridade induziu à seleção da unidade de carboquímicos para que se fizesse a identificação das hipóteses de acidentes presentes nos sistemas e subsistemas desse processo industrial. Para a análise e avaliação dessas hipóteses, aplicou-se a APR-A, de acordo com as alterações propostas, resultando na identificação de vários eventos que provavelmente podem acontecer com consequências criticas e/ou catastróficas para a saúde humana e o meio ambiente. A aplicação da técnica foi realizada dividindo-se a unidade em sistemas e estes em subsistemas. Os eventos críticos e/ou catastróficos identificados foram priorizados para que pudessem ser avaliadas as consequências dessas hipóteses de acidentes.

$\mathrm{Na}$ avaliação das consequências das hipóteses dos acidentes priorizados, aplicou-se a $\mathrm{AE}-\mathrm{A}$, atendendo às modificações propostas no presente trabalho, permitindo avaliar qualitativamente as consequências da efetivação dos eventos citados. Como exemplo do produto da análise de risco ambiental, desde a classificação do risco até a avaliação de sua conseqüência, podem ser citados:

1. o risco de rompimento de parede ou teto do sistema de gasômetros no subsistema gás de coqueria, com liberação de gases tóxicos e efeitos classificados como catastróficos para o meio ambiente: danos severos e morte na populaçăo; restriçăo de uso temporário da regiăo afetada; odores prejudiciais; perda de áreas cultivadas; restriçăo ao uso de meios de transporte; danos substanciais e severos a fauna/fiora, morte de animais; perda de qualidade do ar. 
2. O risco de explosão (ou colapso) do subsistema coluna de "stripping" de amônia no sistema de tratamento do licor amoniacal, com liberação de líquido tóxico para o solo, desprovido de contenção secundária e próximo a galerias de drenagem, que afluem para o estuário de Santos, com efeitos classificados também como catastróficos para o meio ambiente: danos severos ou morte da fauna/flora aquáticas, perda de qualidade do corpo hídrico, perda do potencial de cultivo e pesca, danos econômicos, contaminação dos sedimentos, comprometimento de rede de drenagem e galerias.

Os exemplos da aplicação dessa técnica demonstram a eficácia de sua utilização na análise dos riscos, não só de processo, como também para avaliar os efeitos de um acidente sobre o meio ambiente e a saúde humana. 


\section{Figura 41. Liberaçăo de gases tóxicos - subsistema: Coluna de "stripping" de amónia}

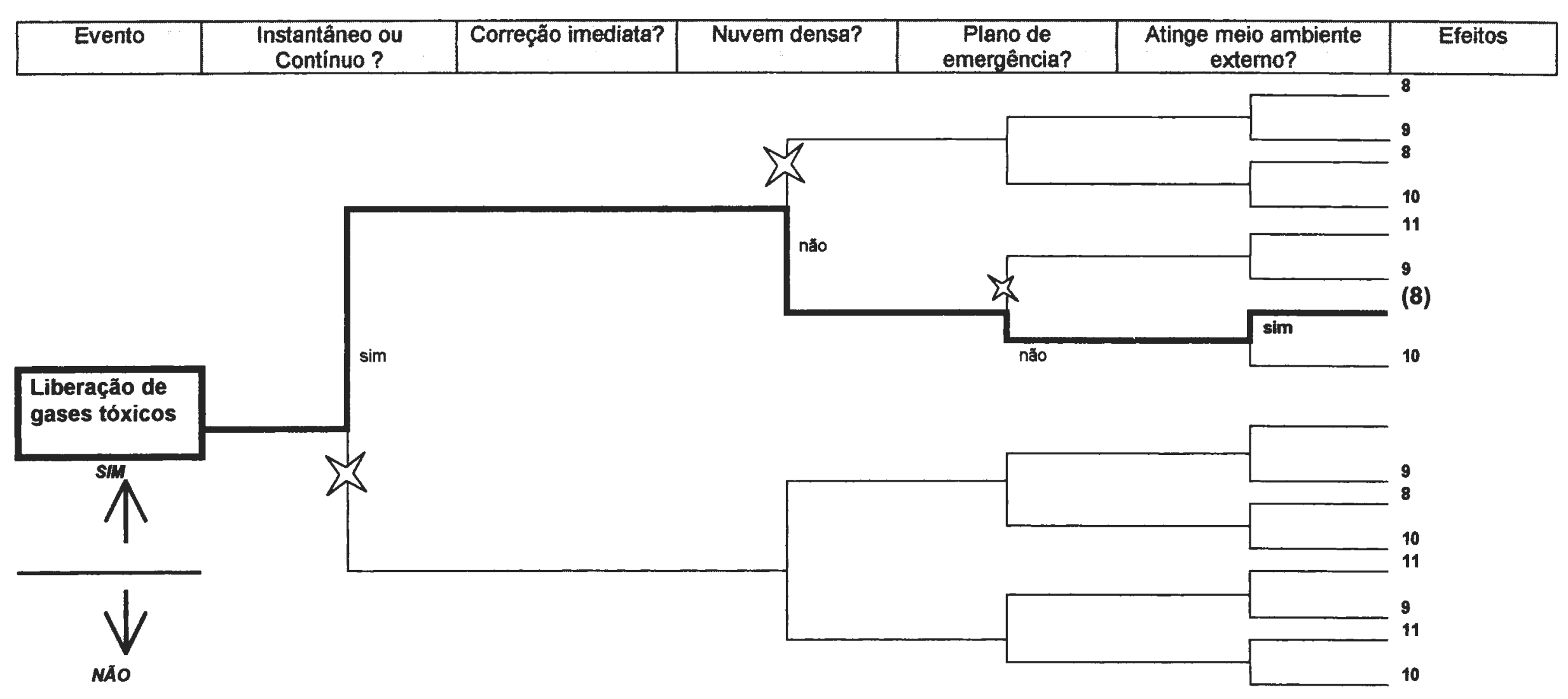


Figura 42. Liberação de líquidos perigosos - subsistema: coluna de "stripping" de amónia

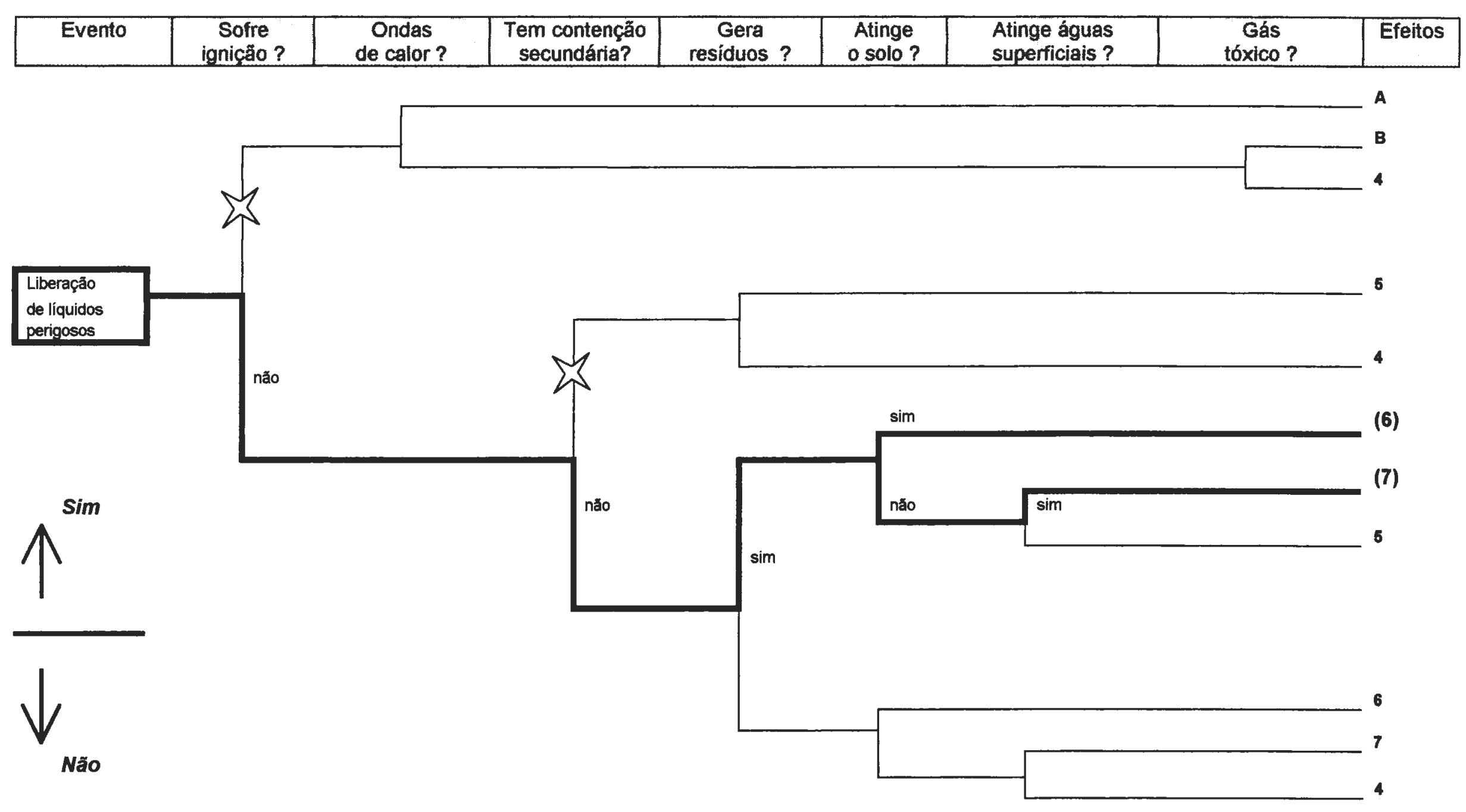


Figura 43. Liberaçăo de substâncias inflamáveis - subsistema: gás de coqueria

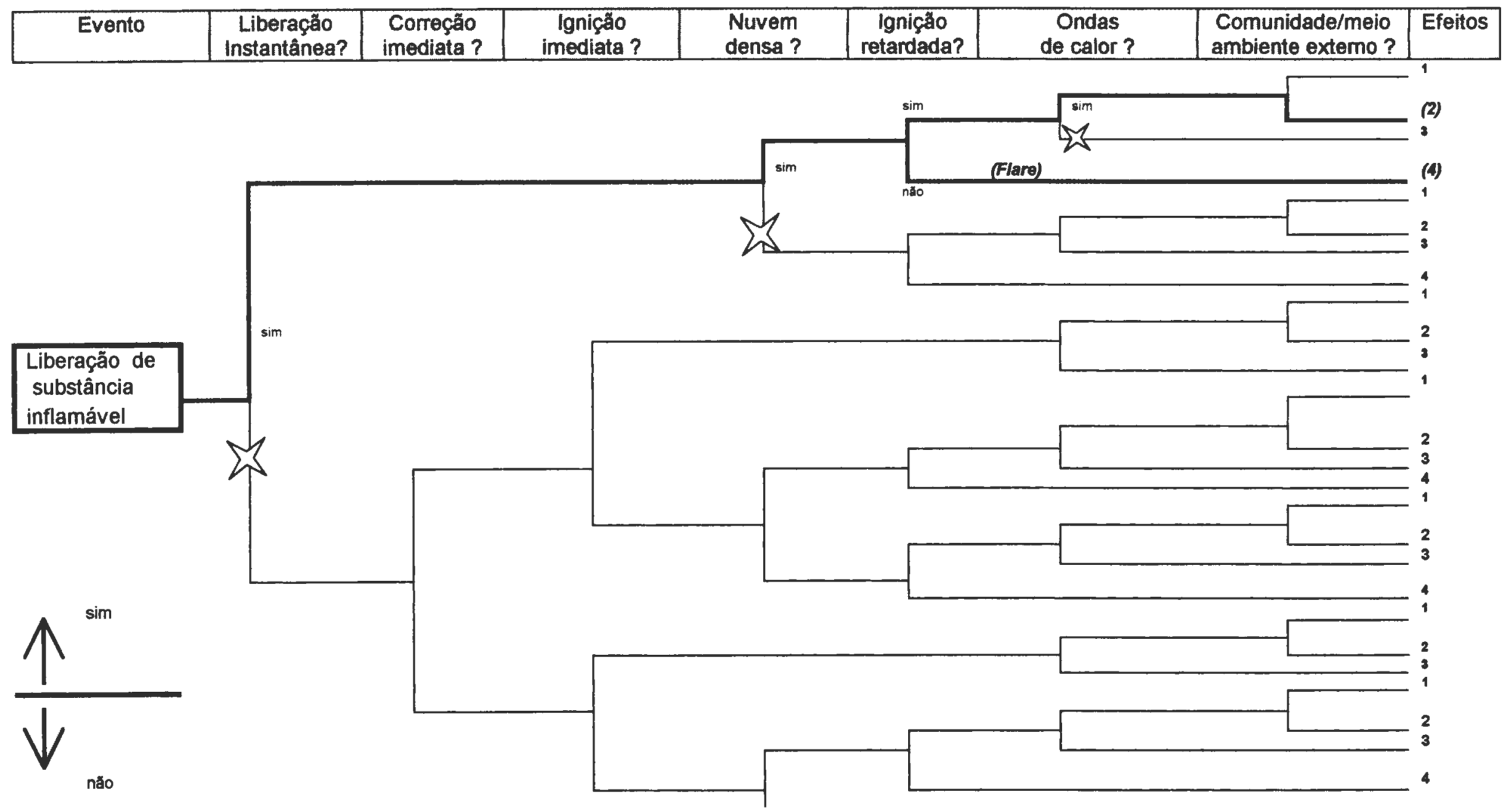


Figura 44. Liberação de líquidos perigosos - subsistema: tanque de óleos leves (carregamento)

\begin{tabular}{|c|c|c|c|c|c|c|c|c|}
\hline Evento & $\begin{array}{c}\text { Sofre } \\
\text { lgniçäo? }\end{array}$ & $\begin{array}{l}\text { Ondas } \\
\text { de calor? }\end{array}$ & $\begin{array}{l}\text { Tem contenção } \\
\text { secundária? }\end{array}$ & $\begin{array}{c}\text { Gera } \\
\text { resíduos? }\end{array}$ & $\begin{array}{l}\text { Atinge } \\
0 \text { solo? }\end{array}$ & $\begin{array}{l}\text { Atinge águas } \\
\text { superficiais? }\end{array}$ & $\begin{array}{l}\text { Qás } \\
\text { tóxico? }\end{array}$ & Efeitos \\
\hline
\end{tabular}

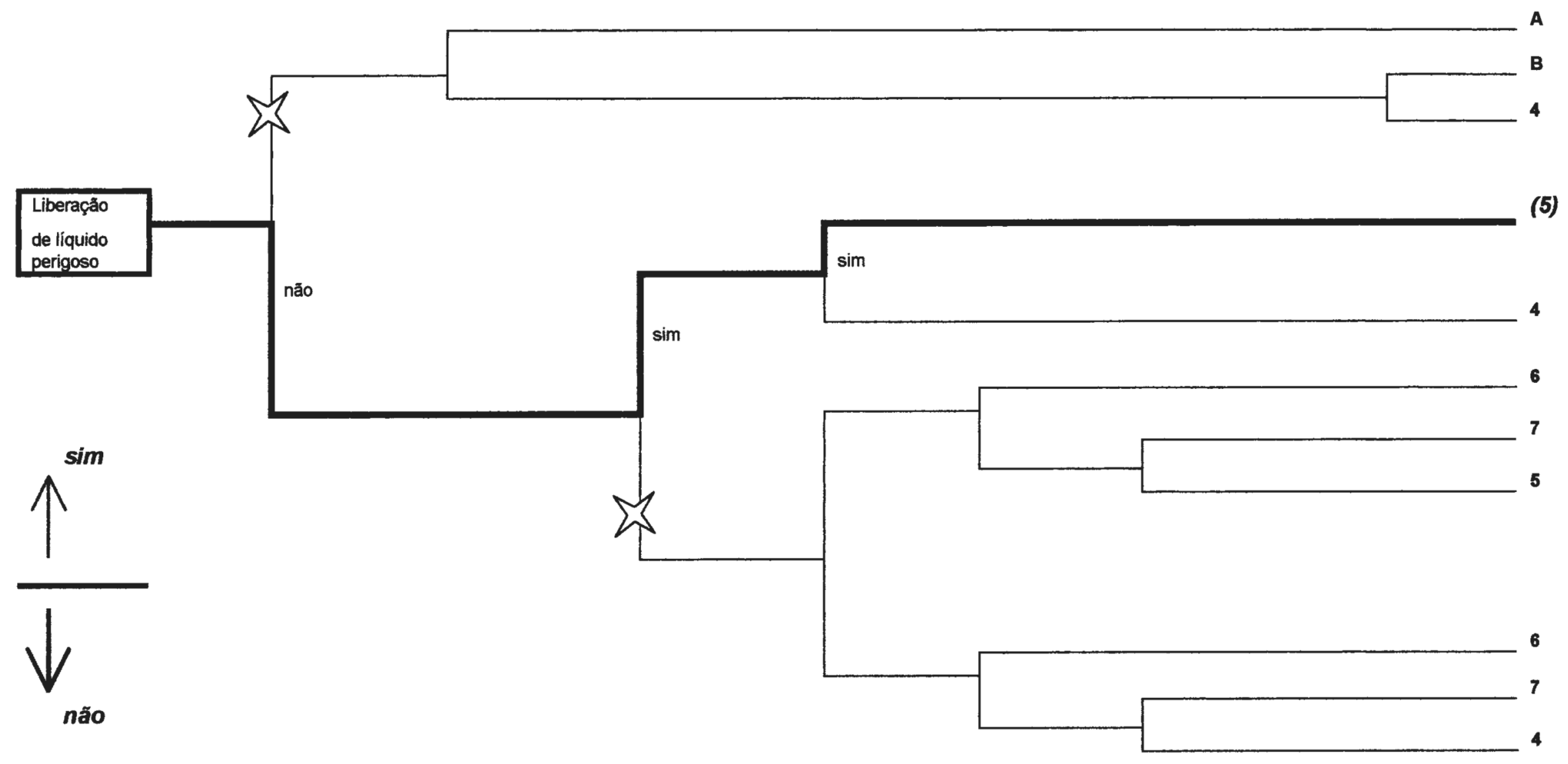




\section{PROPOSTA DE INCLUSÃO DA ANÁLISE DE RISCO AMBIENTAL NA LEGISLACÃO}

\subsection{A legislaçăo ambiental internacional}

Conforme citado por STRICOFF (1996), alguns países vêm, recentemente, atualizando as suas legislações específicas, normalmente as referentes a meio ambiente, saúde e transporte, para conter exigência ou recomendação para que as indústrias dirijam seus esforços visando implantar programas de gerenciamento de segurança, incluindo: gerenciamento de sistemas, avaliação de perigos, análise de risco, programas de controle efetivos e rotinas de inspeção.

Nos Estados Unidos, quatro Estados (New Jersey, California, Delaware e Nevada) desenvolveram regulamentos legais visando reduzir a probabilidade de eventos catastróficos em suas comunidades. Os regulamentos consideram atividades para obtenção do objetivo proposto, iniciando todas elas pela análise e documentação dos riscos ambientais, bem como à segurança e saúde humanas. A legislação federal americana relacionada ao risco à saúde e meio ambiente é, ainda segundo STRICOFF (1996), regulamentada pela Occupational Safety and Health Administration - OSHA (relativa à segurança do trabalhador através do gerenciamento de substâncias altamente perigosas) e pela Environmental Protection Agency - EPA (relativa ao meio ambiente). $O$ "Clean Air Act Ammendments", emitido pela EPA em 1990, propōe, inclusive, a elaboração do Programa de Gerenciamento de Risco para Prevenção de Acidentes Químicos por Vazamentos. Segundo BARTELL (1996), existem oito leis federais produzidas para proteção ambiental contra substâncias tóxicas. A avaliação do risco ecológico vem sendo aplicada para o gerenciamento e remediação de áreas contaminadas através do Resource Conservation and Recovery Act - RCRA de 1976 e do Comprehensive Environmental Response, Compensation and Liability ACt - CERCLA, ou "Superfund", de 1980.

Em 1989, o Comitê para Metodologia de Avaliação de Riscos da National Resource Council's Commision on Life Sciences se propôs a desenvolver técnicas especificas que avaliassem o risco à saúde humana e ao meio ambiente. O Comitê considerou, segundo BARNTHOUSE (1993) que a existência de técnica específica que possa identificar ambos os riscos irá atender ao objetivo principal da avaliação de risco, que é interrelacionar os conhecimentos técnicos e científicos dos aspectos de segurança e meio ambiente, aos processos decisórios de fazer ou não fazer e às exigências legais.

No Canadá, a avaliação de risco ao meio ambiente está definida no Canadian Environmental Protection Act (CEPA). A avaliação é feita baseada no monitoramento das emissões ou despejos de substâncias perigosas, na exposiçăo dos ecossistemas às substâncias perigosas identificadas através de medições no ambiente ou de modelos matemáticos de dispersão (água, ar, solo), e na avaliaçăo do efeito que determina a concentração aceitável de exposição de uma comunidade, população ou ecossistema. Não há, portanto, uma menção clara quanto à aplicação de técnicas de análise de risco ambiental ou de segurança, para avaliação do risco a sistemas ecológicos (BARTELL, 1996).

A Organization for Economic Cooperation and Development (OECD), que abriga os paises membros da Comunidade Européia, propöe que a análise de risco de segurança para os riscos industriais adotem a Diretriz de Seveso, de 1982 (MARTIN, 1991). Para as implicações ecológicas, a OECD propõe conceitos similares ao canadense e americano, baseados na toxicidade da substância química, e os implementam através da aplicação de fatores de segurança, desenvolvidos para fornecer maior confiança nos padrões regulamentados e proteção ambiental (USNRC, 1992).

Para a América Latina e Caribe, salvo algumas exceções, os países da região não têm uma legislação formal e clara que forneça subsídios suficientes para o gerenciamento ambiental (FINOL, 1992; ESCARITO, 1995; ZÓBOLI, 1995; MAINI, 1995). Normalmente, a legislação ambiental limita-se a prever algum tipo de comportamento através de regras legais propostas para proteger certos recursos naturais ou prever danos ambientais provocados por algumas 
atividades, industriais ou não. Segundo BRAÑES (1991), os instrumentos legais são criados especificamente para incluir planejamento ambiental e gerenciamento da terra, regulamentar assentamentos humanos, padrões técnicos, avaliação de impacto ambiental, treinamento, pesquisa, monitoramento e avaliações e prevençáo e controle de catástrofes ambientais. 0 mesmo autor faz uma avaliação das legislações ambientais da Colômbia, Venezuela, Peru e México. Desses países, somente o México inclui em sua política ambiental princípios que "assegurem a manutenção dos recursos naturais não renováveis de forma a serem expostos a riscos de danos e de geração de efeitos ecológicos adversos".

Com o objetivo de fornecer uma metodologia prática para avaliar o impacto ambiental de novos empreendimentos, o Banco Interamericano de Desenvolvimento preparou um guia para dar aos paises latino-americanos e do Caribe uma ferramenta básica para o planejamento ambiental de seus projetos, levando em conta as condições biogeofísicas, ecológicas, sócio-econômicas e político-administrativas de diferentes países, através da elaboração do Estudo de Impacto Ambiental (EIA), Segundo esse guia (IDB, 1994a, b, c), a análise de risco é um dos itens que devem ser desenvolvidos para identificar os acidentes ambientais possiveis em um empreendimento. Em alguns casos, o guia já apresenta os tipos de acidentes ambientais possiveis. No IDB (1994a), para termoelétricas, recomenda-se identificar o risco de vazamento de combustivel e episódios de liberação de substâncias gasosas. No IDB (1994b), identifica, como risco ambiental potencial para uma usina hidroelétrica, um grande desabamento diretamente para o reservatório, alterando as condições de represamento e eventualmente provocando grandes vazamentos através dos vertedouros e ondas hidrodinâmicas que poderiam causar danos a embarcações e atividades desenvolvidas nas margens da represa. Já o IDB (1994c), voltado para empreendimentos de energia a partir de biomassa, identifica a probabilidade de dois acidentes ambientais significativos: severa poluição do ar e o risco de contaminação do solo ou água em conseqüência de residuos gerados em destilarias.

\subsection{A legislação ambiental nacional}

\subsubsection{Responsabilidade civil por danos ao meio ambiente}

Segundo CUSTÓDIO (1983), a legislação ambiental brasileira se divide em dois momentos bem distintos: antes e depois de 1981. Até 1981, eram consideradas como "poluição", para todos os efeitos, as emissões das indústrias que não estivessem de acordo com os padrões estabelecidos por leis e normas técnicas. A esse tempo, sob o pressuposto de que toda a atividade produtiva causa um certo impacto ao meio ambiente, eram plenamente toleradas as emissões poluentes que atendessem a determinados parâmetros.

A Lei Federal $n^{\circ} 6938$, de 31 de agosto de 1981, conhecida como Política Nacional do Meio Ambiente, introduziu uma diferença conceitual que serviu como um divisor de águas. Não há mais dano ambiental a salvo da respectiva reparação; a rigor, não há mais emissão poluente tolerada. A nova legislação baseia-se na idéia de que mesmo o resíduo poluente, tolerado pelos padrões estabelecidos, poderá causar um dano ambiental e, portanto, sujeitar o causador do dano ao pagamento de uma indenização. É o conceito da responsabilidade objetiva, ou do risco da atividade, segundo o qual os danos não podem ser partilhados com a comunidade. A sutil diferença está em que uma empresa pode estar atendendo aos limites máximos de poluição legaimente impostos, e assim mesmo vir a ser responsabilizada pelos danos residuais causados. Para tanto, basta que se prove um nexo de causa e efeito entre a atividade da empresa e um determinado dano ambiental. Isso é, em essência, o que se chama de responsabilidade objetiva: para que se constitua a obrigação de reparar um dano ambiental, não é absolutamente necessário que ele tenha sido produzido em decorrência de um ato ilegal (não atendimento aos limites normativos de tolerância, concentração ou intensidade de poluentes), até porque a responsabilidade objetiva dispensa a prova da culpa. É suficiente, em síntese, que a fonte produtiva tenha produzido o dano, atendendo ou não aos padrões previstos para as emissões poluentes.

Estabelecidos os contornos do novo tratamento legal a ser dado ao meio ambiente, veio a Constituição Federal promulgada em outubro de 1988 dar foros de Lei Maior às teses preservacionistas. A Constituição de 1988 dedicou um capitulo inteiro à proteção ao meio 
ambiente (Capítulo VI - Do Meio Ambiente; Título VIII - Da Ordem Social), e no seu todo possui 37 artigos relacionados ao Direito Ambiental e outros cinco atinentes ao Direito Urbanístico.

Segundo MONTEIRO (1996), o texto constitucional estabeleceu uma série de obrigações às autoridades públicas, incluindo (i) a presenvação e recuperação das espécies e dos ecossistemas; (ii) a preservação da variedade $e$ integridade do patrimônio genético, e a supervisão das entidades engajadas em pesquisa e manipulação genética; (iii) a educação ambiental em todos os niveis escolares e a orientação pública quanto à necessidade de preservar o meio ambiente; (iv) a definição das áreas territoriais a serem especialmente protegidas; e (v) a exigência de estudos de impacto ambiental para a instalação de qualquer atividade que possa causar significativa degradação ao equilíbrio ecológico.

Faltava ainda deixar claro que as agressões ao meio ambiente são consideradas como crime. Já havia tipos penais antigos previstos pelo Código Penal, mas já inadequados ao conceito moderno de dano ambiental (arts. 270 e 271, envenenamento de água potável; art. 278, fabrico, exposição ou venda irregular de substâncias perigosas à saúde). Havia também preceitos penais em leis esparsas sobre temas específicos (infrações ao Código de Pesca, Código de Caça, Código Florestal). Não havia dispositivos penais aplicáveis à vasta gama de crimes cometidos contra 0 meio ambiente, em uma sociedade moderna e complexa.

Sob esse aspecto, as normas de Direito Ambiental têm sempre pelo menos um dos seguintes escopos: prevençåo, reparaçăo, repressåo, gerando três tipos de responsabilidade, independentes entre si: responsabilidade civil, responsabilidade administrativa, responsabilidade penal.

De acordo com MONTEIRO (1996), a responsabilidade civil é baseada em conceitos básicos, que podem ser assim interpretada, quando considera os aspectos relativos ao meio ambiente:

Primeiro conceito básico: "Dano ambiental" - Qualquer alteração "in pejus" (para pior) ao equilíbrio ecológico é considerada dano ambiental.

Segundo conceito básico - "Titular dos direitos ambientais subjetivos" - A "vítima" dos danos ambientais é a coletividade, a sociedade (interesse difuso), enquanto que o causador do dano é, quase sempre, um particular. Prevalência do interesse coletivo.

Terceiro conceito básico - "Responsabilidade objetiva" - Para alguém ser responsabilizado por danos ambientais, basta:

1. haver o dano;

2. ter sido o dano causado por conduta omissiva ou comissiva, qualquer que seja, desse alguém. Tal conduta causadora do dano pode ser, inclusive, lícita (por exemplo, estabelecimento plenamente licenciado) ou decorrente de caso fortuito, força maior ou fato de terceiro (por exemplo, ex-proprietário do estabelecimento).

Quarto conceito básico - "Solidariedade obrigacional" - Todos os causadores de danos ambientais respondem integralmente pelo dano, ainda que causadores parciais (garantido o direito de regresso).

Quinto conceito básico - "Consequências da responsabilidade" - Consequências práticas da responsabilidade civil por danos ambientais:

- reparação do dano: repor ao estado anterior (reconstituição ou recuperação do que foi degradado); indenização.

- sanção: multas diárias; suspensão das atividades; encerramento das atividades; obra específica.

- responsabilidade civil regressiva dos profissionais envolvidos com o dano (por negligência, imperícia ou imprudência).

Sexto conceito básico - "Tutela jurisdicional" - Processos e procedimentos civis condenatórios relativos à responsabilidade ambiental: inquérito civil (Ministério Público), ação civil pública (Ministério Público, Associações e Poder Público), ação popular (qualquer cidadão). 
Pelos conceitos de responsabilidade administrativa, independentemente da responsabilidade civil, os órgãos ambientais de controle e fiscalização podem impor sanções àqueles que causarem dano ambiental ou meramente estejam em desacordo com os padrões normativos. Os tipos de sanções administrativas variam desde advertência e/ou multa até a suspensão ou cancelamento do registro.

Embora a Constituição Federal (Artigo 225, parágrafo terceiro) considere a responsabilidade penal de pessoas jurídicas, o Código Penal brasileiro (de 1969) ainda não foi modificado para permitir a condenação criminal de empresas. Assim, os únicos sujeitos passiveis de criminalização por delitos ambientais são as pessoas naturais, especialmente prepostos (gerentes) e dirigentes das empresas e estabelecimentos poluidores (COSTA JR. \& GREGORI, 1981).

De acordo com a Lei $n^{\circ} 7804$, de julho de 1989, um poluidor que põe em risco a integridade humana, animal ou vegetal, ou que agrava uma situação de risco pré-existente, estará sujeito a pena de prisão de um a três anos e à imposição de uma multa. A pena é dobrada se do ato delituoso resulta: (i) dano irreversivel à fauna, flora e ao meio ambiente; (ii) lesão corporal grave. A sanção é igualmente dobrada se: (iii) a emissão poluente deriva de uma atividade industrial ou de transporte; ou (iv) o delito é cometido à noite, em um domingo ou feriado. Qualquer autoridade que se omita no prevenir essa conduta, também estará sujeita às mesmas penalidades.

O artigo $7^{\circ}$ da Constituição Federal, por sua vez, aborda os aspectos de segurança do trabalho incluindo, no inciso 32, a necessidade de "redução dos riscos inerentes ao trabalho por meio de normas de saúde, de higiene e segurança do trabalho". A esse respeito, a Lei Federal $n^{\circ} 6514$, de 22 de dezembro de 1977, através da Portaria do Ministério do Trabalho $n^{\circ} 3214$, de 08 de julho de 1978, estabelece as Normas Regulamentadoras (NR) de Segurança e Medicina do Trabalho. A NR-15 - Atividades e Operações insalubres, relaciona, no Anexo $n^{\circ} 11$, os agentes químicos cuja concentração obtida em amostragens não deve ultrapassar valores estipulados, sob pena de ser considerada situação de risco grave e iminente. A NR-16 define as atividades e operações perigosas, entre elas as operações com explosivos e inflamáveis, que ofereçam riscos à saúde humana (ATLAS, 1997).

A Lei Federal 8080 de 19 de setembro de 1990, que dispõe sobre as condições para a promoção, proteção e recuperação da saúde, da organização e funcionamento dos serviços de saúde, no seu artigo $6^{\circ}$, parágrafo $3^{\circ} \mathrm{e}$ inciso II, inclui, no campo de atuação do Sistema Único de Saúde (SUS) em estudos, pesquisas, avaliaçåo e controle dos riscos e agravos potenciais à saúde, existentes no processo de trabalho, bem como a necessidade de informar ao trabalhador e à sua respectiva entidade sindical e às empresas sobre o resultado dessa avaliaçăo dos riscos (inciso $\mathrm{V}$ ).

\subsubsection{Análise da legislação ambiental brasileira}

A legislação federal relativa ao gerenciamento e controle ambiental, através da instituição do Sistema Nacional de Meio Ambiente (SISNAMA) - Lei $n^{\circ} 6938$, de 31 de agosto de 1981, praticamente não considera a prevenção do risco de um acidente ambiental, havendo referência à palavra perigo (expressa uma exposição relativa a um risco, que favorece a sua materialização em danos (DE CICCO \& FANTAZZINI, 1985)) no Artigo 15० - "o poluidor que expuser a perigo a incolumidade humana, animal ou vegetal, ou estiver tornando mais grave a situaçåo de perigo existente, fica sujeito a reclusão de um a três anos e multa de 100 (cem) a 1000 (mil) MVR" (este artigo tem redação baseada na Lei $n^{\circ} 7804 / 89$ ).

As Leis, Decretos, Resoluções, Portarias e Instruções Normativas existentes até dezembro de 1997, não mencionavam a necessidade de realização, por qualquer meio, de estudos ou avaliações que identifiquem, analisem e determinem as consequências de acidentes ambientais. A única exceçăo é o Artigo $9^{\circ}$ da Lei Federal $n^{\circ} 6803$, de 02 de julho de 1980 , que trata do licenciamento para implantação, operação e ampliação de estabelecimentos industriais, nas áreas críticas de poluição, e exige a observância do disposto na Lei, bem como do atendimento das normas e padrões ambientais definidos pela SEMA (atual IBAMA), pelos organismos estaduais e municipais competentes, notadamente quanto às seguintes características dos processos de produção: 
1 - emissão de gases e vapores, ruído, vibrações e radiações;

II - riscos de explosăo, incêndio, vazamentos danosos e outras situações de emergência;

III - quantidade e tipo de insumos básicos, de pessoal e de tráfego gerado;

IV -

No Artigo $10^{\circ}$, inciso III da mesma lei, é imputado ao Governo do Estado "manter nas zonas críticas de poluição serviços permanentes de segurança e prevençåo de acidentes danosos ao meio ambiente. Nessa lei, são identificados os riscos maiores existentes numa atividade industrial, passiveis de causar danos ambientais. A forma de expressão do item II deveria ser entendida como exigência para identificar, analisar e controlar esses riscos maiores.

No entanto, o Decreto Federal $n^{\circ} 99274$, de 06 de junho de 1990 (que regulamenta a Lei Federal $n^{\circ} 6938 / 81$, e que trata no seu Capítulo IV do Licenciamento das Atividades) impöe a necessidade da licença de construção, instalação, ampliação e funcionamento de atividades tidas como poluidoras; não menciona, porém, a necessidade de se avaliar os riscos presentes nessas atividades (refere-se, entretanto, ao Estudo de Impacto Ambiental - ElA). Porém, no seu Artigo $34^{\circ}$, item XI, relativo às penalidades, sujeita à multa pecuniária quem "causar danos ambientais de qualquer natureza, que provoquem destruição ou outros efeitos desfavoráveis à biota nativa ou às plantas cultivadas e criações de animais", linguagem utilizada para as avaliações de risco e consequências, diferenciando do EIA. A Resolução CONAMA $n^{\circ} 237$, de 19 de dezembro de 1997, vem, de alguma forma, sanar essa deficiência, ao incluir no Artigo $1^{\circ}$, item III, a definição de Estudos Ambientais, como "aqueles relativos aos aspectos ambientais relacionados à localização, instalação, etc., apresentados como subsídio para a licença ambiental requerida, tais como plano e projeto de controle ambiental, .... e análise preliminar de riscon. Considera ainda, no Artigo $2^{\circ}$, parágrafo $2^{\circ}$, que cabe ao órgão ambiental competente definir critérios de exigibilidade levando em conta os riscos ambientais, o porte e outras características do empreendimento ou atividade. $O$ Artigo $10^{\circ}$, que regula o procedimento de licenciamento ambiental, impõe, no item I, que deverá ser definida pelo óngão ambiental competente, com a participação do empreendedor, os documentos, projetos e estudos ambientais (inclui-se ai a análise preliminar de risco) necessários ao início do processo de licenciamento ambiental. O Artigo $19^{\circ}$ estipula que o órgão ambiental competente poderá "suspender ou cancelar uma licença expedida, quando houver, entre outros, superveniência de graves riscos ambientais e de saúde".

\subsubsection{Legislaçס̃es estaduais}

Das correspondências encaminhadas solicitando informações quanto à existência de legislação sobre análise de risco ambiental, a todos os Estados, verificou-se que, na maioria, não se faz menção à análise de risco. Os Estados, cuja legislação foi consultada, ou que responderam informando da ausência dessa exigência, e em cujas leis não se faz menção a análise de risco, foram: Pernambuco, S. Catarina, S. Paulo, Rio de Janeiro (segundo a FEEMA), Minas Gerais, Espirito Santo, Rio Grande do Sul (segundo a FEPAM), Sergipe, Paraiba, Goiás, Acre, Rondônia, Amazonas, Bahia e Piaui (segundo a Curadoria do Meio Ambiente).

Os seguintes Estados não enviaram dados sobre as respectivas legislações (apesar de reiteradas solicitações): Mato Grosso do Sul, Amapá, Roraima, Maranhão, Rio Grande do Norte e Tocantins.

Para os demais Estados, seguem algumas observações sobre o tema "análise de risco", quando mencionado, mesmo que não especificamente risco ambiental.

PARÁ - Segundo a Secretaria de Estado de Ciência, Tecnologia e Meio Ambiente - SECTAM (Ofício $n^{\circ} 613 / 96$ - GAB/SECTAM, de 06.09.96), "a análise é solicitada pela SECTAM (Secretaria de Estado de Ciência, Tecnologia e Meio Ambiente) sob o título de PLANO DE RISCO, quando do processo de licenciamento ambiental, ao ser verificado se as caracteristicas do empreendimento, sua planta industrial e ou atividade representam risco iminente e/ou potencial ao meio ambiente (sócio-econômico, físico e/ou biológico). É regra geral a obrigatoriedade de apresentação desses Planos por empreendimentos que armazenam grande volume de combustiveis derivados de petróleo; de empresas mineradoras, sob a ótica do controle das barragens de rejeitos; de fábricas que manipulam ou produzem produtos perigosos; e de empreendimentos de grande porte e por suas características intrínsecas [como é o caso do complexo da Albrás]". 
MATO GROSSO - Segundo a Fundação Estadual do Meio Ambiente - FEMA (1995), no Código Ambiental do Estado de Mato Grosso há a Lei Complementar $n^{\circ} 36$, de 21.11 .95 , que dispõe sobre o Código Estadual do Meio Ambiente e dá outras providências.

No Capitulo I (Dos Princípios da Política Estadual do Meio Ambiente), Seção VIII (que trata das Auditorias Ambientais), o Artigo 41 menciona que as Auditorias Ambientais deverão considerar:

...(inciso III) - "verificação das matérias-primas, aditivos e sua composição, geradores de energia, processo industrial, sistema e equipamentos de controle da poluiçăo, planos e sistemas de controle de situação de emergência e de risco, e dos subprodutos, resíduos e despejos da atividade auditada".

No Capítulo V (Dos Setores Ambientais), Seção VI (Dos Recursos Hídricos), o Artigo 80 menciona: "As atividades industriais e os depósitos de substâncias capazes de causar riscos aos recursos hídricos deverão ser dotados de dispositivos de segurança e prevenção de acidentes, e deverão estar localizados a uma distância mínima de 300 (trezentos) metros dos corpos d'água, em áreas urbanas, e 1000 (mil) metros, em áreas rurais".

CEARA - A Lei Estadual no 12148, de 29.07.93 (Diário Oficial do Estado do Ceará, p. 40-41), dispõe sobre a realização de Auditorias Ambientais e dá outras providências. No Artigo $2^{\circ}$, parágrafo $2^{\circ}$, menciona que "as diretrizes para a realização de auditorias ambientais poderão incluir, entre outras, avaliações relacionadas aos seguintes aspectos:

...(inciso II) - "avaliação dos riscos de acidentes e dos planos de contingência para evacuação e proteção dos trabalhadores da empresa poluidora, quando necessária, e da população situada na área de influência".

ESPIRITO SANTO - O Decreto Estadual $n^{\circ} 3795-\mathrm{N}$, de 27.12.94, regulamenta a lei 4802 de 02.08.93, que dispõe sobre as Auditorias Ambientais; no Capítulo II, Seção V (das Diretrizes Básicas para a realização de Auditorias Ambientais), consta o Artigo 12 - "As diretrizes básicas para a realização de auditorias ambientais de agentes poluidores considerarão, entre outros, os seguintes aspectos:

...(b) - observações dos riscos de acidentes ambientais e respectivos planos de contingência."

ALAGOAS - O Decreto $\mathrm{n}^{\circ} 33212$, de 08.11.88, dispõe sobre o Sistema Estadual de Licenciamento de Atividades Poluidoras e/ou Degradantes - SELAP, regulamentando o inciso VII do Artigo 16 da Lei 4986 , de 16.05.88, e dando outras providências.

No Artigo $3^{\circ}$, menciona-se: "A remuneração paga pelos interessados, decorrente das Análises de Projetos, emissão de licenças, análise de Estudo de Risco e análises de Estudos de Impacto Ambiental, obedecerá à discriminação referida no Anexo II". Para uma análise de estudo de risco, o valor varia conforme o porte da empresa: micro - 5; pequeno - 12; médio - 30; grande - 100 UPFAL, sendo o porte da empresa determinado segundo o número de empregados/ área/ investimento total.

Já o Decreto $n^{\circ} 33410$, de 28.03 .89 , que regulamenta a lei 4986 , de 16.05 .88 (que cria o Instituto do Meio Ambiente de Alagoas - IMA, e dá providências correlatas), trata, no Capítulo VI (Da Diretoria Técnica e dos seus Órgãos), Seção II (Do Núcleo de Controle Ambiental), Artigo 15, das competências desse Núcleo:

inciso III - "analisar Estudos de Risco e Avaliação de Impacto Ambiental".

O Decreto $\mathrm{n}^{0} 35135$, de 29.10 .91 , altera o Decreto 33212 , de 08.11 .88 , que dispõe sobre o Sistema Estadual de Licenciamento de Atividades Poluidoras e/ou Degradantes - SELAP: em seu Anexo Único, altera os valores da remuneração a ser paga pela análise de estudo de risco, conforme o porte: micro - 5; pequeno - 12; médio - 100; grande - 600 UPFAL.

A Resolução Normativa $n^{\circ} 32 / 88$, que se refere ao Terminal Químico de Alagoas, no inciso IV (que determina restrições para a concessão de nova Licença de Implantação ao TEQUIAL), menciona: 
"b - deverão ser adotadas para a tancagem da epicloridrina as medidas mitigadoras de risco, constantes no Relatório da COPPE/UFRJ...";

d - comprovação, através de estudos de riscos, da não-elevação do risco social do sistema SALGEMATTEQUIAL. Isto significa que deverão ser adotadas medidas mitigadoras de riscos adicionais no sistema, que reduzam o risco social no mesmo percentual do acréscimo causado pela implantação de cada novo inventário;" e, no inciso VII, diz: "Recomendar que a CINAL (Companhia Industrial de Alagoas), na conformidade da legislação ambiental, apresente projeto para implantação do cloroduto na rodovia PCAVSALGEMAITEQUIAL, com vistas à redução do risco representado pelo transporte de cloro através de caminhões-tanque."

A Resolução Normativa $n^{\circ}$ 011/90 também se refere ao risco social: no inciso III, diz: "Fica determinada a necessidade de atendimento às recomendações de estudos mais aprofundados, a serem executados pelo IMA e aprovados pelo CEPRAM, respeitada a não elevação do risco social".

DISTRITO FEDERAL - Segundo o Ofício OE $n^{\circ} 001 / 96$ - GAB - IEMA, de 06.01.97, enviado pelo Instituto de Meio Ambiente do Distrito Federal, "a análise de risco não é objeto de detalhamento pela legislação" local. Existe uma lei ( $n^{\circ} 118$, de 02.08 .90 ), que dispõe sobre a realização de auditoria ambiental, mas não menciona análise de risco.

PARANÁ - A Constituição Estadual do Estado do Paraná, no seu Capítulo V (Do Meio Ambiente), artigo 207, parágrafo $1^{\circ}$, inciso $\mathrm{VI}$, menciona que "cabe ao poder público assegurar a efetividade do direito ao meio ambiente ecologicamente equilibrado.....", através da exigência da "análise de risco para o desenvolvimento de pesquisas, difusão e implantação de tecnologia potencialmente perigosa".

Segundo o IAP - Instituto Ambiental do Paraná (PINHEIRO JR., 1997, comunicação pessoal), o anteprojeto da "Lei Estadual do Meio Ambiente" regulamentará este dispositivo constitucional muito sinteticamente, nos artigos 94 e 95; entretanto, em nenhum instante se exige a AR para atividades específicas, como é o caso do processo siderúrgico. Entretanto, PINHEIRO JR. (1993) trata do assunto, considerando a instalação de empreendimentos diversos.

\subsubsection{Leis Municipais}

As legislações municipais, a exemplo das demais, pouco ou nada acrescentam na exigência da identificação dos riscos ambientais provocados pelos acidentes que envolvem explosão, incêndio e vazamento de substâncias tóxicas. O municipio de Cubatão, que possui um polo petroquímico de grande porte, incluindo 23 indústrias desenvolvendo atividades dos ramos químico, siderúrgico, de fertilizantes e cimenteiro, é uma exceção, por criar, na Lei Orgânica do Município, promulgada em 09 de abril de 1990, no Capítulo IV, do Meio Ambiente, Artigo $n^{\circ}$ 189, item IX, um "sistema de proteção, controle e desenvolvimento do meio ambiente a fim de controlar e fiscalizar a produção, armazenamento, transporte, comercialização, utilização e destino final de substâncias, bem como o uso de técnicas, métodos e instalaçöes que comportem risco efetivo ou potencial para a qualidade de vida e meio ambiente, incluindo o de trabalho, na forma da Lei".

\subsection{Consideraçð̋es gerais}

De modo geral, a análise de risco ambiental não é contemplada, como se pôde verificar, na maioria dos Estados da federação. MILARÉ \& BENJAMIN (1993), que também não discutem o tema em especial, apresentam, nas "Questões práticas", um estudo de caso, referente ao pedido de licenciamento ambiental para ampliação da unidade fabril de celulose e papel e implantação de uma fábrica de cloro-soda, da Riocell S.A., na região metropolitana de Porto Alegre (RS) [p. 166-200, 204-219]. O DMA (Departamento de Meio Ambiente) achou por bem solicitar um estudo de avaliaçăo de riscos da unidade de cloro-soda, tendo em vista suas caracteristicas, localização e porte, que a enquadravam como sendo de "alto risco"; apesar de todas as recomendações feitas pela CETESB (que foi solicitada a colaborar nos procedimentos), foram deferidas, em 91/92, as licenças de instalação e de operação, antes de julgado o EIA/RIMA e AR (HAZOP), apesar da análise da AR ter sido efetuada por técnico "confessamente" inabilitado, "pondo em perigo a vida e a saúde da população". 
Com a edição da Resolução CONAMA $n^{\circ}$ 237, de 19 de dezembro de 1997, incluindo no procedimento administrativo de licenciamento ambiental a apresentação de Estudos Ambientais, tipificou-se a análise preliminar de risco como um dos documentos que poderá ser exigido no processo de licenciamento.

Há, entretanto, uma falha, ao não se definir em que condições ou atividades deve ser exigida a análise de risco. Como verificado ao longo do trabalho, a simples exigência da análise preliminar de risco não implica na identificaçăo dos riscos ao meio ambiente, assim como não evidencia as consequencias desses riscos. Seria, portanto, necessário que a referida Resolução definisse claramente qual a real utilidade e campo de aplicação da análise de risco, determinando o uso da técnica de Análise Preliminar de Risco Ambiental (APR-A) tal como proposta neste trabalho, além de determinar também a avaliaçăo das consequências da efetivação dos acidentes previstos, podendo, para tanto, utilizar a Análise da Árvore de Eventos - Ambiental (AAE-A).

\subsection{Subsídios para proposição de mudanças na legislação}

Embora a Resolução CONAMA no $237 / 97$ inclua, entre os "Estudos Ambientais" a Análise de Risco Preliminar, não fica clara a sua exigência e nem em que atividade ou etapa do licenciamento ambiental essa exigência será feita. Por ser um instrumento de proteção contra acidentes com efeitos sobre 0 meio ambiente e a saúde humana, além de patrimônios particulares e sociais, a análise de risco de acidentes devidos à produção, armazenamento, transporte, distribuição e uso de produtos perigosos deve também ser incorporada ao Estudo de Impacto Ambiental quando da exigência de realização desse estudo.

A incorporação ao EIA se faz necessária pois, durante a elaboração dos estudos, o empreendedor limita-se, na grande maioria das vezes, a identificar e controlar as fontes de poluição, contínuas ou não, existentes no processo de produção ou atividade. Dessa forma, não há a preocupação de identificar, analisar e estimar as consequências de prováveis acidentes devido à presença de substâncias classificadas como perigosas e em quantidade suficiente para provocar danos ao meio ambiente e à saúde humana.

Também o ato de fiscalizar o controle desses riscos inerentes aos processos ou atividades é falho. Como não foram identificados ou analisados os riscos presentes, não há também propostas de ações ou mecanismos para preveni-los ou controlá-los devidamente. Nesta situação, fica o agente credenciado do órgão ambiental competente sem um instrumento técnico para verificar se o risco existente tem, ou não, um controle efetivo e em conformidade com as exigências técnicas e legais.

Em seguimento ao exposto, e com os objetivos de:

1. tornar mais seguras as operações e atividades que implicam na produção, armazenamento, transporte, distribuição e uso de produtos perigosos, principalmente as do setor siderúrgico, e

2. imprimir maior efetividade aos documentos legais já existentes, são propostas as inserçöes e mudanças a serem efetuadas nas Resoluçōes do CONAMA (Conselho Nacional do Meio Ambiente), mormente nas Resoluções CONAMA 01/86 e 237/97, que o presente trabalho julga oportuno:

- acrescentar ao Artigo $5^{\circ}$ da Resolução CONAMA 01/86:

$V$ - identificar, analisar e estimar as consequências dos riscos ambientais presentes nas fases de implantação e operação da atividade.

- acrescentar ao Artigo $6^{\circ}$ da Resolução CONAMA 01/86:

$V$ - análise dos riscos ambientais do projeto e de suas alternativas, através de técnicas de análise de risco ambiental, determinando o grau de risco das atividades previstas e definindo as medidas de prevenção e controle, além dos planos de ação emergenciais.

- modificar o inciso IV do Artigo $6^{\circ}$ da Resolução CONAMA 01/86: 
IV - elaboração do programa de acompanhamento e monitoramento dos impactos positivos e negativos e dos riscos ao meio ambiente identificados, indicando os fatores e parâmetros a serem considerados.

- acrescentar ao Artigo $9^{\circ}$ da Resolução CONAMA 01/86:

IV - incluir, após "a descrição dos prováveis impactos ambientais": e riscos de acidentes.

- modificar o inciso III do Artigo $1^{\circ}$ da Resolução CONAMA 237/97:

sugere-se a troca da técnica proposta, análise preliminar de risco, pela expressão análise de risco ambiental, que dará ao empreendedor a oportunidade de, além de identificar e hierarquizar os riscos das atividades em licenciamento, estimar as consequências para o meio ambiente dos prováveis acidentes.

Estas sugestões constituem a proposta de alteração na legislação nacional, a serem, posteriormente, encaminhadas à esfera federal, para que sejam analisadas, discutidas e, esperase, incluídas nessa legislação, objetivando o aprimoramento das medidas de proteção ambiental, auxiliando no adequado gerenciamento dos recursos naturais. A sua adoção pela legislação federal implicará, automaticamente, na exigência de implementação nas legislações estaduais, visto que estas não poderão ser menos exigentes que a primeira. No entanto, recomendações no sentido de incorporar as sugestões propostas nos processos de licenciamento ambiental dos Estados poderão também ser encaminhadas. 


\section{ESTIMATIVA DE CUSTO DA ANÁLISE DE RISCO AMBIENTAL DE PROCESSO SIDERÚRGICO}

Para uma empresa, é importante distinguir os custos ambientais da empresa dos custos impostos pela sociedade, os chamados "custos sociais". São exemplos clássicos de custos sociais os efeitos à saúde decorrentes do ar contaminado, o impacto da poluição das águas no ecossistema aquático, ou o impacto da contaminação do solo para os organismos vivos. Por outro lado, a legislação/regulamentaçōes, políticas corporativas, preferências do consumidor e as pressōes da comunidade sobre alguns custos sociais retornam às firmas.

Limites de descarga de efluentes, taxas de emissão, exigências do ciclo de vida do produto, prevenção de riscos ambientais e outros instrumentos políticos também criam pendências para as firmas reduzirem potencialmente os seus impactos ambientais, obrigando o poluidor a pagar mais caro. Alguns destes custos já estão sendo passados para as firmas como despesas para a tecnologia do controle da poluição, contratação de pessoal especializado em meio ambiente e taxas de licenças. Entretanto, estes custos são indiretos e, a longo prazo, tendem a não serem reconhecidos (DITZ et al., 1995).

Recentemente, alguns líderes ambientais e de negócios têm usado a contabilidade dos custos totais para descrever e praticar a introdução dos custos ambientais, antes considerados externos às decisões corporativas. Esta ampla interpretação condensa uma gama de custos sociais e privados impostos através do ciclo de vida do produto, ou seja, desde a extração da matériaprima até a disposição final do produto. A contabilidade dos custos totais descreve como os insumos e os serviços podem ser contabilizados, a fim de refletir o verdadeiro custo ambiental, inclusive produção, uso, reciclagem e disposição final. Assim, os consumidores podem avaliar as consequências económicas totais de suas escolhas, ambas internas e externas. Se todas as firmas seguissem este critério, os preços levariam os clientes a comprar produtos de custos totais menores. Entretanto, qualquer firma que aumentasse o preço de seus produtos poluentes estaria em desvantagem, face aos competidores de preços mais baixos (DITZ et al., 1995).

É comum, entre os especialistas em meio ambiente e ciências contábeis, considerar a real dificuldade em estimar os benefícios relativos ao controle ambiental (VAUGHAN \& ARDILA, 1993). O problema real existente é a precisão das estimativas feitas dos custos ou benefícios do controle ambiental. Sob esse aspecto, é muito importante uma análise econômica, ao fornecer ao empreendedor dados sobre a necessidade de prosseguir com um investimento projetado para prevenir danos ambientais, ou mesmo decidir até onde deve ir o projeto, mesmo que não sejam exclusivamente ambientais.

Contudo, os custos do controle da poluição e das políticas de gerenciamento dos recursos naturais e redução de riscos não podem ser avaliados isoladamente daqueles que não são percebidos em termos de danos evitados ou prevenidos. Para entender melhor os custos ambientais, deveria ser calculado o que poderia acontecer se os investimentos não fossem realizados.

Em junho de 1997, a revista "Veja" publicou um artigo intitulado "O valor do verde", no qual o autor (TRAUMANN, 1997) afirma que a idéia de medir em cifras econômicas a importância da natureza não é nova. De fato, o artigo cita cientistas americanos que avaliaram os benefícios proporcionados aos seres humanos por dezesseis grandes ecossistemas, incluindo entre eles as florestas tropicais, os oceanos, os estuários e as áreas de mangue. $O$ resultado da equação é surpreendente: 33 trilhões de dólares anuais. $O$ valor encontrado é quase duas vezes a riqueza produzida no mundo durante um ano. $O$ importante do estudo, realizado pela Universidade de Maryland (EUA), é mostrar o quanto são importantes alguns ecossistemas, especialmente aqueles que são responsáveis pela reprodução de espécies, reabastecimento dos meios que envolvem ciclos geoquímicos, etc.

Segundo VAUGHAN \& ARDILA (1993), o custo agregado do controle ambiental não é pequeno, importando, nos Estados Unidos, em cerca de $2 \%$ do Produto Nacional Bruto, e deverá estar em 
$3 \%$ no início do ano 2000. No Brasil, as obras de despoluição do rio Tietê, em São Paulo, e da baia de Guanabara, no Rio de Janeiro, estão orçadas em aproximadamente 1,700 bilhões de dólares.

A contabilidade ambiental é uma ferramenta que pode ser usada para unir as informações ambientais aos dados sobre o ativo, recursos, custos e aos dados financeiros de uma empresa. As informações contábeis podem facilitar a tomada de decisões nesta área complexa. O sistema atual pode fornecer informações sobre os projetos de meio ambiente e os recursos ambientais tendem a ser concentrados em custos de capital e despesas diretas. Entretanto, em muitos casos, outros custos podem exceder os custos diretos. Por exemplo, o custo gerado por uma atividade de remediação pode exceder os lucros obtidos por uma empresa durante toda a sua existência (MAEVE, 1994). Em alguns casos, o custo da recuperação de áreas contaminadas por um produto, tal como o óleo PCB utilizado em sistemas elétricos, pode ser maior do que os custos para, inicialmente, produzir o produto.

Atualmente, as empresas consideram interessante a aplicação de técnicas tais como a prevenção da poluição e risco de acidentes ambientais, a fim de minimizar custos. Porém, as empresas devem considerar qual é realmente o maior interesse (coincidentemente benéfico ao meio ambiente), decorrente das inadequações em seu processo, para que os custos sejam completamente contabilizados. Em algumas situações, as decisões ambientais poderiam ser aprimoradas se os custos totais e os benefícios fossem melhor entendidos no início do processo de tomada das decisões.

Decisões relacionadas à proteção ambiental são consideradas complexas e arriscadas e têm potencial para enormes impactos financeiros. Os custos para remediação de derrames, vazamentos ou outros acidentes ambientais, mais as multas, penalidades, custos legais, danos, perda de imagem comercial e más decisões têm aumentado dramaticamente nas últimas décadas. A tradicional análise financeira de eventos futuros com cenários bons ou ruins é inadequada, pois ignora os componentes de risco nas análises feitas (EPSTEIN, 1996).

Novas técnicas para a análise de risco foram desenvolvidas recentemente, e as técnicas existentes foram e estão sendo aprimoradas e aplicadas para reconhecer e prevenir os riscos ambientais.

A análise de risco ambiental (ARA) é uma ferramenta utilizada para a orientação clara e prática do administrador de um empreendimento em operação ou do projetista, na fase de elaboração do projeto de um novo empreendimento. É uma ferramenta de planejamento verdadeiramente eficiente para a prevenção de riscos ao meio ambiente, saúde humana e patrimônio.

O objetivo deste trabalho é, portanto, auxiliar o empreendedor a levar a termo, com sucesso, todos os passos necessários para uma análise de risco ambiental (ARA) e melhorar seu planejamento, através da definição dos custos envolvidos no trabalho.

\subsection{O processo de análise de risco ambiental}

Como descrito no capítulo 3.1, a ARA envolve vários processos, que levam o empreendedor a decidir se um risco é aceitável ou não, e quais as ações que devem ser seguidas para mitigar ou eliminar tal risco. Pode ainda o empreendedor optar por um controle efetivo do risco, e resguardar-se de ações futuras, no caso de ocorrência de um acidente, através de ações de seguradoras. Embora a ARA envolva vários processos técnicos, a sua execução ocorre seguindo seis etapas principais, que vão desde a definição de sua necessidade até a sua aplicação prática. Essas etapas podem ser resumidas em:

- Identificação dos riscos

- Planejamento

- Contratação

- Execução

- Divulgação/Treinamento

- Avaliação final 


\subsubsection{Identificaçåo dos riscos presentes na empresa}

Este processo deverá ser desenvolvido prioritariamente pela empresa, visando conhecer as unidades que apresentam riscos maiores e que podem causar danos ao meio ambiente (Tab. 28). A partir do conhecimento do grau de risco ambiental das unidades, deverá ser obtida a categoria de risco dessas unidades e a partir daí, elaborar uma ordem de prioridade de realizaçäo da análise de risco ambiental (ARA). Nesta atividade, estão previstas as seguintes atividades e consumo de horas:

Tabela 28. Estimativa de horas para identficação dos riscos da empresa

\begin{tabular}{|c|c|c|}
\hline Atividades & $\begin{array}{l}\text { Nede } \\
\text { récnicos }\end{array}$ & No de horas \\
\hline $\begin{array}{l}\text { Obtenção dos dados referentes às substâncias perigosas } \\
\text { presentes }\end{array}$ & 2 & 40 \\
\hline $\begin{array}{l}\text { Obtenção das condições de processo/armazenamento das } \\
\text { substâncias perigosas }\end{array}$ & 2 & 40 \\
\hline $\begin{array}{l}\text { Avaliação das condiçōes ambientais (recursos naturais, } \\
\text { biogeofísicos e sócio-econômicos) }\end{array}$ & 2 & 80 \\
\hline $\begin{array}{l}\text { Elaboração dos cálculos e obtenção da classificação } \\
\text { Emissão do relatório }\end{array}$ & $\begin{array}{l}3 \\
1\end{array}$ & $\begin{array}{c}150 \\
20\end{array}$ \\
\hline Tolal & 3 & 330 \\
\hline
\end{tabular}

Evidentemente, cada uma dessas etapas envolve uma série de sub-etapas, e cada uma delas inclui o uso de técnicos treinados, operadores ou projetistas, desenhos, projetos, visitas às áreas, reuniões, consultas a bancos de dados, bibliografia especializada, órgãos públicos, etc.. Essas atividades têm um custo, que será abordado neste trabalho.

\subsubsection{Planejamento}

Uma vez tomada a decisão de elaborar uma análise de risco de um processo, unidade, setor, empresa, atividade, etc., deverá ser definido um plano de trabalho que possibilite determinar as operações necessárias para o inicio dos trabalhos e que envolvem as outras três etapas. Esse plano de trabalho deve conter as seguintes operaçōes e/ou atividades (Tab. 29) que levarão à segunda etapa do processo de realização da ARA:

a: definição de um responsável pela ARA;

b: definição do grupo de trabalho;

c: reuniăo para definir 0 alcance da ARA:

d: definição da necessidade de contratação de técnicos especializados.

Tabela 29. Estimativa de horas para planejamento da ARA

\begin{tabular}{c|c|c}
\hline Atividades & $\mathbb{N}^{\circ}$ de tocnicos & $N^{\circ} \cdot$ de horas \\
\hline$a+b$ & 1 & 8 \\
$c$ & 3 a 4 & 32 \\
$d$ & 3 a 4 & 10 \\
\hline Total & 3 a 4 & 50 \\
\hline
\end{tabular}

\subsubsection{Contratação}

O alcance do trabalho, a complexidade das técnicas a serem aplicadas, a análise dos eventos com efeitos sobre o meio ambiente, saúde humana e o patrimônio/sistema, a interpretação das exigências legais, as medidas mitigadoras e de controle exigidas e os aspectos econômicos e de responsabilidade civil existentes indicam que a melhor alternativa para a sua realização é a contratação de técnicos ou empresas especializadas. 
Esta etapa também envolve custos diretos e indiretos pois, para a sua execução, deverão ser consultados outros departamentos ou gerências da empresa, onde serão preparados os termos técnicos de referência para o recebimento e análise de propostas técnicas e financeiras. Além disso, deverá ser disponibilizado um técnico que possa acompanhar as empresas interessadas em apresentar uma proposta para atender à solicitação do trabalho.

Estima-se que nesta etapa sejam consumidas aproximadamente 30 horas/homem.

\subsubsection{Execução}

A execução da ARA é a etapa mais complexa do processo, pois abrange várias operações intermediárias e que devem ser levadas em conta. Algumas dessas operações estão previstas no processo de execução da análise de risco ambiental, outras não estão implicitamente relacionadas no fluxograma que resume a execução da ARA. Essas atividades intermediárias implicam em gastos adicionais de horas/homem que podem igualar ou mesmo suplantar um dado processo principal. Para efeito de se conhecer os custos existentes na elaboração da ARA, essas atividades devem ser consideradas, a fim de não causar surpresas desagradáveis ao empreendedor ou mesmo criar um parâmetro de comparação que poderá ser utilizado para avaliar as propostas financeiras, no caso de contratação de serviços externos.

Uma ARA para um processo siderúrgico, devido à complexidade das unidades e sistemas existentes e infinidade de operações e atividades a serem consideradas, além do porte de cada unidade, é ampla e exige um grande esforço e conhecimento técnico por parte dos responsáveis pela sua realização. Neste caso, é prática subdividir o processo siderúrgico em unidades ou sistemas, para concentrar os esforços técnicos e obter um melhor resultado. Para alguns sistemas, é recomendável realizar outras divisões, tendo-se assim sub-sistemas que poderão ser analisados com maior eficiência.

O presente trabalho, visando facilitar o entendimento do consumo de horas necessárias e possibilitar o desdobramento desse conceito para qualquer sistema dentro do processo siderúrgico, considera que a execução proposta se refere a um sistema, dentro de uma unidade qualquer, tomando como exemplo:

\section{Sistema considerado}

Desgaseificação

Dessulfuração

Regenerador

Tancagem

Calcinação

laminação tiras a frio

laminação chapas grossas

laminação tiras a quente

forno-poço/desbastador

britagem de carvão

pátio de carvão

pátio de cal

Decapagem

recuperação de ácido

tratamento de efluentes

Escarfagem

tratamento térmico

Unidade
Aciaria
alto-forno
alto-forno
Carboquímico
Sinterização
Laminação
Laminação
Laminação
laminação
coqueria
matéria-prima
matéria-prima
laminação
decapagem
carboquímicos
laminação
laminação

Entre as atividades que serão necessárias desenvolver, estão aquelas relativas à identificação dos recursos naturais, biogeofísicos e sócio-econômicos, além da definição clara da área de influência das operações da empresa. Os dados obtidos poderão ser utilizados para todos os sistemas a serem avaliados, desde que não ocorram lapsos de tempo muito grandes entre os levantamentos feitos ou mudanças nas condições de preservação desse meio. 
A seguir, são apresentadas as atividades previstas para a preparação e obtenção de dados para a confecção da APR-A e da AE-A:

1. reunião inicial para entendimento da solicitação (entre os membros do grupo ou com a empresa contratada);

2. visita ao sistema a ser avaliado - ou discussão do projeto;

3. definição da área de influência do empreendimento (considerar uso de mapa contendo detalhes tais como vegetação, corpos d'água superficiais, relevo, circulação do ar, clima, urbanização, vizinhança, uso e ocupação do solo, outras atividades industriais, vias de transporte, meios de comunicação, dutos, etc.);

4. definição das técnicas de ARA a serem aplicadas;

5. treinamento do pessoal técnico e operacional que deverá participar da ARA;

6. definição dos padrões de qualidade e situação de conservação e uso dos recursos naturais existentes, distâncias, projetos de uso, etc.;

7. obtenção de recursos para realização da ARA e para as reuniões do grupo;

8. definição e obtenção dos recursos técnicos necessários e disponiveis ("lay-out", projetos, modificações, redes de drenagem, esgotos auxiliares, dutos, equipamentos de segurança e de controle de acidentes, programas de manutenção, normas e procedimentos operacionais, etc.);

9. obtenção de histórico de acidentes através de consulta a bancos de dados, registros da área de segurança ou consulta a outras empresas;

Para a execução das atividades listadas (1 a 9), estima-se que será necessário o emprego de 2 (dois) técnicos e consumo de 100 horas.

10.definição das hipóteses de acidentes (para a sua realização, está sendo indicado o uso da APR-A, que necessita para sua elaboração de um técnico treinado na técnica e análise de risco e os efeitos sobre o meio ambiente, a saúde humana e o patrimônio/sistema).

A seguir, estão descritas as atividades envolvidas na APR-A (Tab. 30) e a estimativa de horas a serem consumidas na análise do sistema escolhido:

Tabela 30. Estimativa de horas para elaboração da APR-A

\begin{tabular}{|c|c|c|}
\hline Atividades & $\begin{array}{c}N^{0} \text { de } \\
\text { tonicos }\end{array}$ & $\begin{array}{l}N^{0} \text { de } \\
\text { horas }\end{array}$ \\
\hline Análise do banco de dados de acidentes & 1 & 10 \\
\hline $\begin{array}{l}\text { Reuniōes para identificação dos riscos, causas, efeitos, propostas } \\
\text { de controle e obtenção da categoria do risco identificado }\end{array}$ & 3 & 210 \\
\hline Emissão do relatório & 1 & 20 \\
\hline Total & 3 & 240 \\
\hline
\end{tabular}

11.seleção dos riscos mais importantes identificados na APR-A (refere-se à elaboração de uma lista dos riscos que apresentam maior grau de severidade no caso da efetivação do evento negativo. Estima-se o consumo total de 5 (cinco) horas para a realização da atividade.

12.avaliação das consequências dos riscos mais severos, já ordenados. Nesta atividade, deverá ser desenvolvida a análise da ánore de eventos ambiental (AE-A), conforme proposto neste trabalho. Para sua realização, será necessária a participação de um técnico treinado na elaboração da técnica de análise de risco e na avaliação dos danos ambientais à saúde humana e patrimonial/sistema. Porém, recomenda-se a formação de um grupo com três a quatro técnicos com experiência na operação do sistema e conhecimento de processos quimicos. 
A elaboração da AE-A deverá depender do número e complexidade dos eventos iniciantes, conforme definidos na APR-A.

A seguir, estão descritas as principais atividades envolvidas na AE-A (Tab. 31) e a estimativa de horas a serem consumidas na análise do sistema escolhido:

Tabela 31. Estimativa de horas para elaboraçăo da AE-A

\begin{tabular}{l|c|c}
\multicolumn{1}{c|}{ Atividades } & $\begin{array}{c}N_{0}{ }^{\circ} \text { de } \\
\text { trcnicos }\end{array}$ & $\begin{array}{c}N_{*}{ }^{\circ} \text { de } \\
\text { horas }\end{array}$ \\
\hline Ondenação dos eventos iniciantes & 1 & 05 \\
Reuniōes para elaboração da AE-A & 4 & 320 \\
Emissão do relatório, contendo as árvores e efeitos identificados & 1 & 40 \\
\hline \multicolumn{1}{c|}{ Total } & 4 & 365 \\
\hline
\end{tabular}

\subsubsection{Divulgaçăo/Treinamento}

Obtida a ARA para um dado sistema, é imperativo que os resultados encontrados sejam divulgados para os operadores desse sistema, líderes, chefias e gerência. O conhecimento e análise do relatório final deve ser levado à chefia e gerência, a fím de obter sua participação na implantação das medidas de proteção recomendadas e nos possíveis danos causados pela realização de um acidente. Deve também ser previsto o treinamento das chefias, lideranças e operadores do sistema, objetivando a sua conscientização e açäo emergencial correta em caso de acidente, conforme descrito da ARA.

A divulgação/treinamento não são atividades que fazem parte da realização da ARA; entretanto, é conveniente prever recursos financeiros para essas atividades, pois são de grande interesse para a área objeto da análise.

Estima-se que sejam consumidas 4 (quatro) horas para treinamento de uma equipe de 5 (cinco) técnicos que operam um sistema de porte médio, dentro de uma unidade da indústria siderúngica. Considerando uma equipe de 100 pessoas, seräo necessárias 80 horas de cursos e palestras.

\subsubsection{Avaliaçăo final}

Ao final dos trabalhos, é conveniente a realização de uma auditoria em todo o processo relativo à análise de risco ambiental do sistema escolhido, a fim de verificar a conformidade das questőes identificadas na ARA. O relatório final da auditoria é o ponto de início de um Plano de Açăo que inclua todos os aspectos não conformes declarados no relatório de auditoria. Essa atividade deve ser realizada pelo técnico responsável pela ARA e mais dois operadores que tenham participado ou não da análise.

Estima-se que sejam consumidas 100 horas nessa atividade, incluindo a apresentaçăo do Plano de Açăo.

\subsection{Estimativa da quantidade total de horas necessárias para a ARA de um dado sistema,} das unidades de uma indústria siderúrgica

Na tabela 32 apresenta-se a quantidade de horas estimadas para elaboraçäo das técnicas propostas para a ARA de um sistema. A figura 45 representa os dados comparativamente. 
Tabela 32. Estimativa de horas consumidas para elaboraçáo das técnicas de análise de risco ambiental, por subsistema, em uma usina siderúrgica

\begin{tabular}{c|c|c}
\hline Técnica & $\begin{array}{c}\text { Quantidade de } \\
\text { horas }\end{array}$ & $\%$ \\
\hline Identificação dos riscos presentes (CATBRAS) & 330 & 35 \\
Definição das hipóteses de acidentes (APR-A) & 240 & 26 \\
Avaliação das consequências (AE-A) & 365 & 39 \\
\hline Total & 935 & 100 \\
\hline
\end{tabular}

Figura 45. Quantidade de horas consumidas na realização das técnicas de ARA

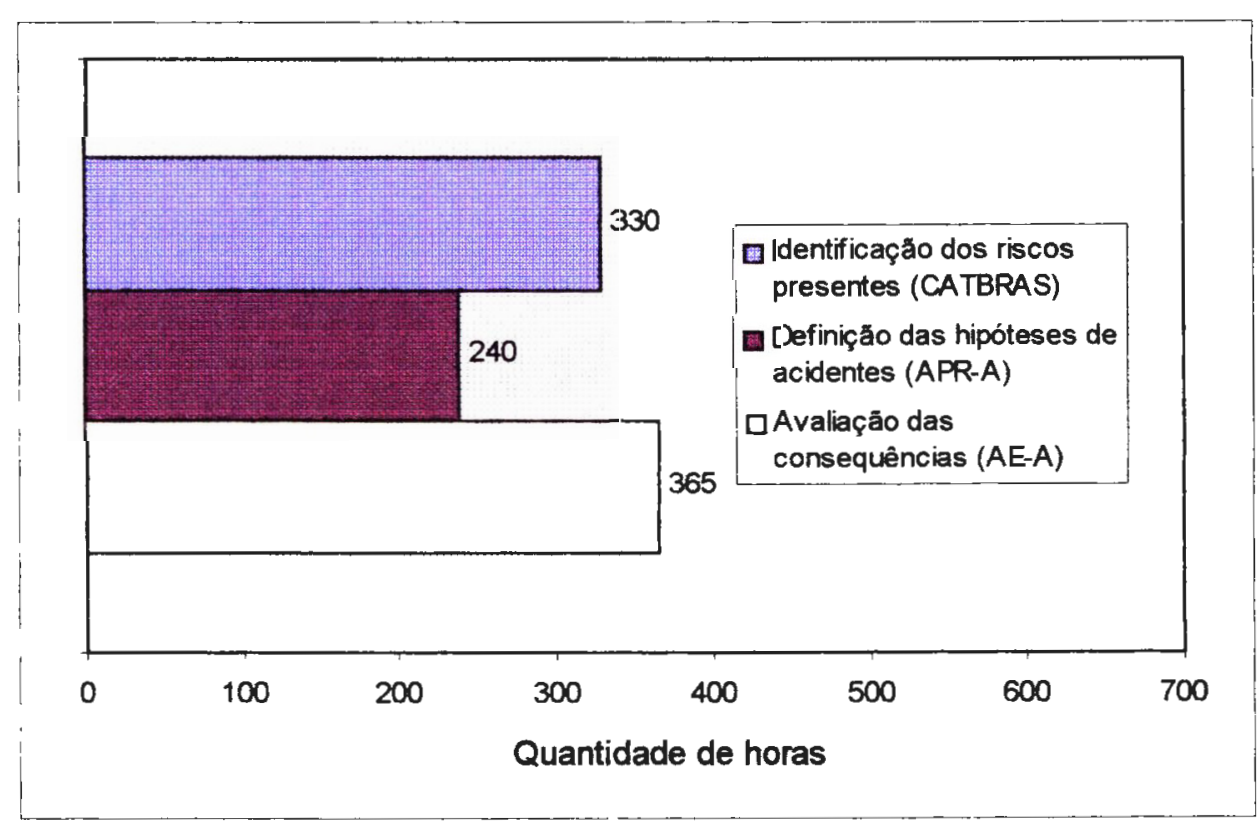

Uma avaliação dos números obtidos para a elaboração da ARA mostra que a etapa que consome maior quantidade de horas é a avaliação de consequências dos eventos, através do emprego da AE-A. Entretanto, a quantidade estimada pode variar, em função do porte e complexidade do sistema avaliado. Na tabela 33, a seguir, apresenta-se um resumo das atividades necessárias para a elaboração da ARA e a quantidade estimada de horas gastas em cada uma delas. A figura 46 representa os valores estimados.

Tabela 33. Estimativa do total de horas consumidas no processo de execuçáo da ARA

\begin{tabular}{l|c|c}
\hline \multicolumn{1}{c|}{ Atividades } & $\begin{array}{c}\text { Quantidade de } \\
\text { horas }\end{array}$ & $\%$ \\
\hline Identificação dos riscos presentes & 330 & 25 \\
Planejamento & 50 & 4 \\
Contratação & 30 & 2 \\
Execução: & 710 & 55 \\
- preparação e obtenção de dados (100h) & & \\
- definição das hipóteses de acidentes (APR-A) (240h) & & \\
- seleção dos riscos maiores (5h) & & \\
- avaliação das consequências (AE-A) (365h) & 80 & 6 \\
Divulgação/treinamento & 100 & 8 \\
Avaliação final e Plano de Ação & 1300 & 100 \\
\hline \multicolumn{1}{c|}{ Total } & & \\
\hline \multicolumn{1}{c|}{}
\end{tabular}


Figura 46. Quantidade de horas consumidas no processo de realizaçăo da ARA

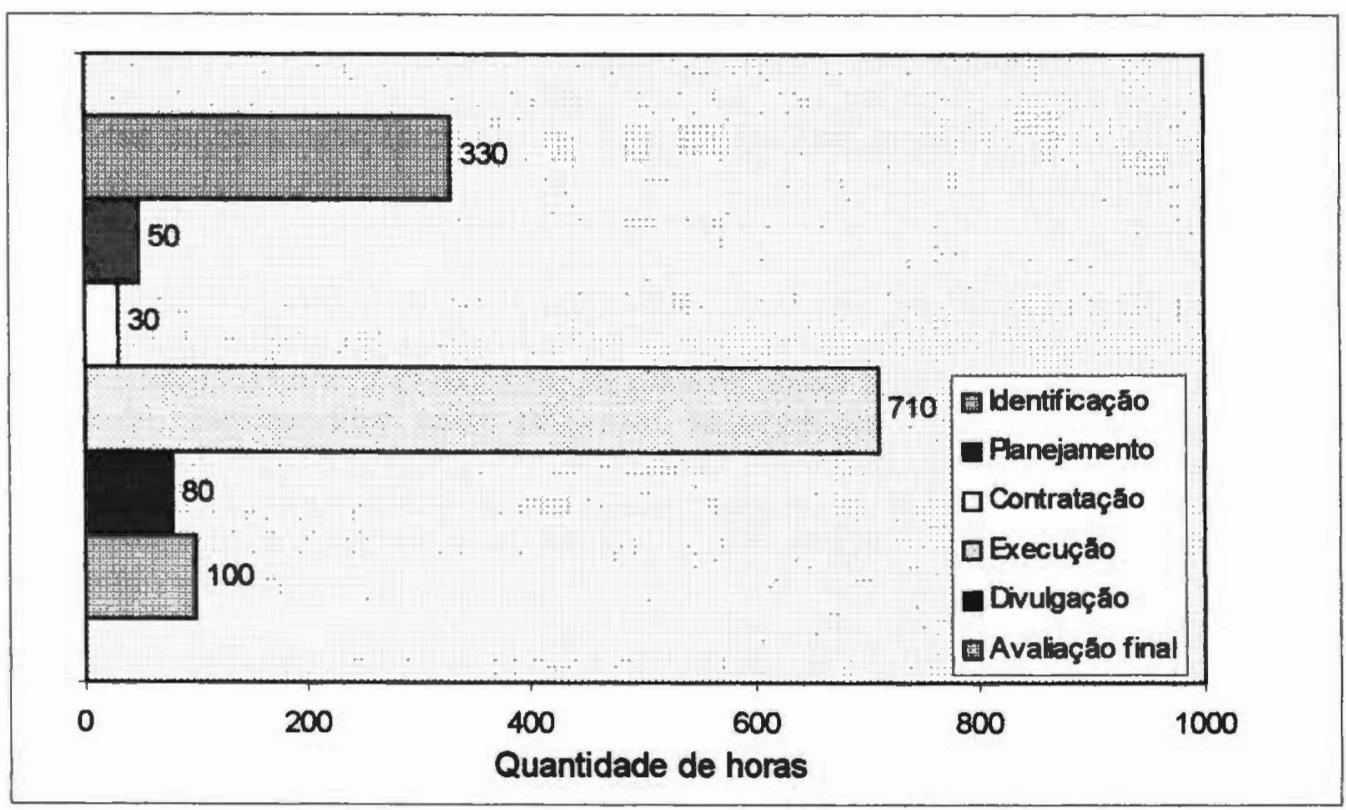

\subsection{Considerações}

A elaboração de uma análise de risco envolvendo a classificação, identificação das hipóteses de acidentes e a avaliação das consequências dos eventos previstos requer a participação de técnicos treinados e diversas etapas de trabalho. Cada etapa consome um grande número de horas/homem, resultando em cerca de 1300 horas para a efetivação da ARA para um dado sistema. As técnicas requerem cerca de 365 horas para a $A E-A, 330$ para a elaboração da classificação de risco da empresa e 240 para realizar a APR-A de um sistema, dentro de uma unidade siderúrgica. $O$ restante das horas previstas é consumido em tarefas auxiliares.

O custo da mão de obra especializada varia enormemente. Nas empresas especializadas, o valor da hora/homem varia de $R \$ 60,00$ a $R \$ 180,00$, resultando em um custo estimado da ordem de R\$78.000,00 a R\$ $108.000,00$. Evidentemente, a empresa poderá realizar a ARA com recursos próprios. Nesse caso, pode parecer que haverá uma grande redução no custo total do trabalho; entretanto, nem sempre se confirma essa expectativa. Vários fatores, tais como disponibilidade, especialização, envolvimento de vários profissionais, relacionamentos internos, prioridades das áreas envolvidas, recursos externos necessários, etc., acabam por dificultar ou mesmo impedir a realizaçăo de um estudo abrangente, identificando e classificando os riscos mais sérios e principalmente propondo medidas de prevenção e controle dos acidentes descritos.

Embora a primeira impressão seja de um custo elevado, a execução da ARA pode e deve ser feita, pois, comparando-se os custos de recuperaçăo de unidades, perda de produtos, danos à saúde humana e ao meio ambiente, verificar-se-á que o conhecimento dos riscos e seu controle sairão bem mais em conta, compensando de longe seu investimento. 


\section{O GERENCIAMENTO E A COMUNICACÃO DE RISCOS AMBIENTAIS}

Apesar de não estarem definidos dentro do escopo do presente trabalho, dois aspectos devem aqui ser abordados, para complementar as considerações sobre os métodos propostos: o processo de comunicaçăo de risco, e o gerenciamento de risco.

\subsection{O gerenciamento dos riscos ambientais}

O resultado da análise de risco ambiental (ARA) é uma estimativa do risco para um sistema, determinado através da aplicação das técnicas apropriadas. Os resultados obtidos na ARA devem ser comparados com os critérios legais para os riscos à segurança e saúde humanas, para o meio ambiente, determinados pelas empresas seguradoras e pelos critérios internos das empresas (SANTOS, 1991). Quando esses critérios não são atendidos ou são ultrapassados, devem então ser levadas adiante medidas de controle de freqüência ou conseqüência, a fim de obter resultados que coloquem a empresa novamente em conformidade com os critérios estipulados legal ou corporativamente.

A falta de uma legislação ou padrão específico para o controle dos riscos identificados em um sistema não deve inibir as açōes do empreendedor no sentido de minimizar esses riscos, devendo o mesmo agir pró-ativamente na eliminação, mitigação e controle dos eventos previstos. As medidas de redução dos riscos devem diminuir a probabilidade de ocorrência e as consequências de um evento, ou mesmo eliminar a chance de sua ocorrência. Essas medidas normalmente são feitas através de um plano de açăo, baseado nos riscos identificados, nas técnicas, equipamentos e procedimentos disponiveis, nos custos e na definição de responsabilidade pela sua execução. A decisão de controlar, o que controlar, quando controlar, treinar, comunicar, etc., faz parte do gerenciamento de risco de uma empresa.

O gerenciamento de risco é, portanto, um processo que deve incluir a avaliação e, se necessário, controle das fontes de exposição e do risco. De acordo com GOOSSENS (1991), esse processo vem sendo adotado pelas empresas não só para atender a uma crescente exigência por parte das autoridades ligadas à segurança e saúde humana, às companhias seguradoras mas também, mais recentemente, ao meio ambiente. Neste último aspecto, a exigência de realização da análise de risco ambiental já consta da legislação federal (Resolução CONAMA $n^{\circ}$ 237/97) e vários estados brasileiros vêm impondo a elaboração de um programa de gerenciamento do risco ambiental.

Segundo ALLENBY (1996), a avaliação e o gerenciamento de risco ambiental podem e devem aplicar principios ecológicos. Com eles, pode-se elaborar uma abordagem holistica e abrangente baseada em sistema que reflita a necessidade de equilibrar os impactos com base nas múltiplas necessidades, algumas vezes conflitantes entre si.

Uma das vantagens do programa de gerenciamento dos riscos, conforme percebido por várias empresas, é a possibilidade de avaliar e prevenir a poluição ambiental através da realização da avaliação do risco e da análise de risco presente, o que certamente dá ao empreendedor a necessária segurança para proteger os membros da sociedade, o meio ambiente e a própria sobrevivência da empresa (HUBERT et al., 1991).

O gerenciamento dos riscos ambientais certamente inclui estratégias, algumas já citadas, para a sua efetiva implementação, devendo-se reconhecer que alguns dos riscos apresentarão riscos residuais - isto é, não serão totalmente controlados, e que os fatores que influem na determinação de um risco ambiental podem sofrer alterações. Assim sendo, é essencial aceitar algumas possiveis variaçōes periódicas e sistemáticas no gerenciamento dos riscos, utilizando procedimentos de auditorias no programa.

Na realidade, o gerenciamento de risco em uma empresa é iniciado quando são tomadas decisões para a realização da análise de risco ambiental dos processos e atividades industriais. 
Os primeiros passos nesse sentido são aqueles referentes à definição da necessidade de realizála; quem vai estar coordenando os trabalhos, quais unidades serão analisadas, custos, prazos iniciais, etc.. Entretanto, somente após o conhecimento dos riscos e formas de controle é que os riscos poderão ser realmente gerenciados.

No presente trabalho, várias unidades foram analisadas em uma indústria siderúrgica, para se obter a classe de risco ambiental de cada uma delas. Essa classificação foi obtida com o uso da CATBRAS, modificada conforme proposta. A classificação deve ser incluída no Programa de Gerenciamento de Risco Ambiental - PGRA, com a definição da prioridade de elaboração da identificação das hipóteses de acidentes.

Após a identificação das hipóteses de acidentes e estimadas as consequências ambientais dos eventos estudados, é elaborado o Plano de Ação para Controle dos Riscos e definidas outras estratégias que irăo compor o PGRA. Essas estratégias devem, no mínimo:

- definir a prioridade de controle;

- decidir assumir ou não o risco identificado;

- treinar operadores;

- identificar o uso de substâncias não perigosas;

- reduzir a capacidade de armazenamento;

- rever sistemas de proteção e controle de acidentes;

- implantar monitoramento e testes;

- alterar processos ou atividades;

- implantar controles redundantes;

- definir e implantar Plano de Emergência Ambiental;

- compor-se com áreas de segurança e meio ambiente de outras fábricas e órgãos públicos afins;

- encerrar operação de alto risco onde não é possível controle eficiente;

- definir e implantar Plano de Comunicação de Risco, incluindo situaçăo normal e situaçăo de crise;

- identificar fontes externas de recursos humanos;

- identificar fontes externas de recursos financeiros;

- acompanhar a legislação ambiental;

- realizar auditorias internas;

- realizar auditorias externas;

- relacionar-se oficialmente com órgãos estaduais e entidades competentes.

Evidentemente, a relação acima não é excludente nem abrange todas as estratégias que devem estar contidas no PGRA, porém dá uma boa noção da complexidade presente no processo de gerenciamento dos riscos ambientais levantados.

A elaboração do PGRA trará à empresa a confiabilidade no seu processo e a certeza de não ser surpreendida por acidentes que venham a reduzir ou impedir o seu desenvolvimento, problemas de imagem, permanência na região ou mesmo a paralização definitiva dos seus negócios e atividades.

\subsection{A comunicação de riscos ambientais}

Após a identificação e avaliação dos riscos ambientais existentes na empresa, restam ao empreendedor mais três etapas:

1. providenciar açōes de controle e de emergência;

2. treinar os operadores dos subsistemas avaliados; $\mathbf{e}$

3. comunicar ao público e às autoridades os riscos identificados.

As duas primeiras etapas foram apresentadas e discutidas ao longo do trabalho, ficando a terceira, embora não a mais complexa, para ser considerada com a ênfase necessária no final.

Segundo COVELLO (1996), a comunicação de risco pode ser definida como "a troca de informações entre partes interessadas na natureza, magnitude, significância ou controle de um risco". As informações sobre os riscos presentes em uma atividade podem ser comunicadas 
através de uma diversidade de meios. Assim sendo, inúmeros acidentes com consequências ambientais vêm, seguidamente, sendo transmitidos pela imprensa, conscientizando as pessoas dos riscos existentes nas várias atividades, industriais ou não, presentes no dia-a-dia de cada um. Muitas vezes, essas informações chegam ao público de forma errada ou distorcida, exatamente por não haver uma comunicação clara e precisa aos interessados sobre o que realmente ocorreu, suas implicações, medidas de controle, ações futuras, etc..

De qualquer maneira, a existência ou não, de maiores informações corretas sobre as operações de uma indústria e os riscos que elas trazem, é uma necessidade cada vez maior das comunidades envolvidas. Novas leis e regulamentos estão sendo desenvolvidos e aplicados; a maior facilidade e rapidez das informações, inclusive com imagens gravadas ou não, a organização de setores da sociedade e o forte apelo político e acadêmico têm pressionado o empreendedor a reconhecer e informar ao público interno e externo da empresa, o que acontece, ou pode acontecer, na sua indústria.

O fato de uma indústria não se comunicar com o público e as autoridades certamente gera uma desconfiança e descrédito quanto à sua forma de administrar suas atividades. Nesses casos, somente os empregados são os porta-vozes da empresa, o que nem sempre é recomendável, ficando a imagem da empresa entregue a pessoas despreparadas para essa atividade.

A atuação, quando a empresa não está sob nenhuma pressão, é definida como "situaçăo normaf", isto é, não ocorreram acidentes que envolvessem lesões médias/graves ou mortes, danos à propriedade e danos substanciais/severos ao meio ambiente. Nessa fase, espera-se da empresa contatos formais, diretos ou indiretos com seus vizinhos (população, indústria, comércio), consumidores, clientes, fornecedores, contratados, imprensa, políticos, centros de pesquisa, organizaçöes s entidades não-governamentais e autoridades (principalmente as vinculadas ao atendimento a casos de emergências), quando poderá identificar claramente, e sem gerar preocupações, os riscos e as medidas de segurança e controle existentes no seu processo industrial ou atividade. Nessa atuação, o empreendedor pode, e deve, interagir com seus novos pares, procurando mantê-los informados e até mesmo preparados, para casos de acidentes maiores (SANTOS, 1987).

A segunda forma de atuação é conhecida como situaçăo de crise, ou a realização de um evento não planejado, com efeito sobre o meio ambiente, segurança ou saúde humana ou mesmo sobre a imagem da empresa. Uma situaçăo de crise pode levar a um profundo impacto sobre as operações da indústria, sua economia, mercado, reputação e até mesmo ser envolvida em responsabilidades legais. Por ser evento que requer rápidas decisões e ações, necessitam de um plano de gerenciamento de crise, que deve ser administrado por técnicos especializados e com planos de ação que constem de um programa de comunicaçăo de riscos.

Não é escopo deste trabalho relacionar ou descrever técnicas ou procedimentos para as situaçðes de crise ou situaçסes normais, visto ser uma área abrangente e que requer uma especialização por parte do técnico responsável pelo seu planejamento e execução. Entretanto, devem ser feitas mençōes quanto à real necessidade da elaboração e implantação de um programa formal de comunicação de riscos ambientais e de segurança e saúde humanas (SANTOS, 1990). Como verificado nos exemplos dados neste trabalho, uma atividade siderúrgica apresenta riscos classificados como catastroficos, isto é, podem causar danos irreparáveis ao meio e lesões graves ou morte à população humana. Por esse e por outros fatos, tais como as enormes quantidades de substâncias perigosas existentes no processo e/ou armazenadas, as altas temperaturas e pressões empregadas e a energia acumulada nos processos, é que se propõe, como exigência complementar à ARA, a elaboração e implantação de um programa de comunicação de riscos de acidentes, contendo um plano de gerenciamento de situação de crise, para uma atividade industrial de risco, e, em especial, para os processos siderúrgicos.

É evidente que a comunicação de risco em ambas as situaçōes deve ser planejada e realizada de forma a não provocar no público ansiedades e preocupações que venham a se converter em fatores negativos para a empresa e levar à exigência, legal ou não, de novas e dispendiosas formas e estruturas de controle dos riscos identificados ou mesmo dos recursos técnicos ou dos procedimentos do Plano de Emergência (SANTOS et al., 1996). 


\section{CONCLUSÕES E RECOMENDACÕES}

Ao longo do desenvolvimento deste trabalho, foram feitas várias avaliações preliminares a respeito do processo de obtenção do aço, dos riscos presentes em suas inúmeras operações e atividades, da necessidade de mão-de-obra numerosa e especializada, do erro lógico de instalação das indústrias (poucas ou nenhuma indústria siderúrgica realizou um estudo de impacto ambiental antes de sua implantação), do uso de várias substâncias perigosas, altas pressões e temperaturas e armazenamento de grande volume de combustiveis e outras substâncias, que possibilitaram afirmar que o processo siderúrgico possui várias condições para provocar acidentes com consequências inaceitáveis.

Da mesma forma, foram relacionadas e discutidas várias técnicas que permitem equacionar o problema encontrado quando estão juntas todas as condições de risco presentes na indústria siderúrgica e a necessidade de proteção da propriedade, da vida humana e do meio ambiente. Essas técnicas, reconhecidas como análise de risco, foram avaliadas em relação à sua aplicação original e a possibilidade, e utilidade, de aprimorá-las para contemplar a variável meio ambiente.

Por outro lado, a identificação e avaliação dos riscos, ambientais ou não, embora tenha motivado os governos de vários países, não motivaram o governo federal brasileiro e os estaduais a perseguirem uma forma de regulamentá-los e controlá-los, através de legislação clara e específica.

Entretanto, essas avaliações sobre o processo industrial, a análise de risco do processo siderúrgico e a necessidade de haver uma legislação específica para sua realização possibilitaram a obtenção de algumas conclusões e a elaboração de recomendações que demonstram ser a análise de risco ambiental um instrumento indispensável na previsão e controle de acidentes que tenham como conseqüência a probabilidade de causar dano ao meio ambiente.

\section{Sobre o processo siderúrgico:}

- Embora seja considerado como um grande gerador de poluentes, o processo siderúrgico não é percebido pela comunidade como possuidor de um alto potencial de risco ambiental. No entanto, o processo siderúrgico, devido ao armazenamento de grande quantidade de substâncias perigosas (tóxicas, inflamáveis, explosivas), é classificado como possuidor de alto potencial de risco.

- As usinas siderúrgicas instaladas no país não realizaram análises de risco ambiental no seu processo de licenciamento ambiental.

- Por necessitar do emprego de mão-de-obra qualificada e numerosa, grande volume de água com boa qualidade, combustível, e vias de transporte, as indústrias siderúrgicas estão instaladas em áreas ambientalmente sensiveis.

- O histórico de acidentes maiores (explosão, incêndio e liberação de substâncias tóxicas) registra que a unidade de Carboquímicos responde pela maioria dos acidentes ocorridos, seguida pela unidade de Coqueria.

\section{Sobre a análise de risco ambiental:}

- Não há um banco de dados nacional atualizado. A CETESB possui um banco de dados (CADAC), atualizado e de fácil acesso, que registra os acidentes ocorridos no Estado de $S$. Paulo.

- Embora existam bancos de dados internacionais especificos para acidentes industriais, a sua aquisição e atualização é dispendiosa.

- O histórico de acidentes obtido nos bancos de dados registra que a grande maioria dos acidentes é devida a vazamentos de substâncias perigosas.

- O mesmo histórico indica serem os corpos hídricos os meios mais atingidos pela realização de acidentes maiores. 
- As técnicas existentes para análise de risco de processos (segurança e saúde humanas e propriedade), embora mencionem a devida preocupação com os danos ao meio ambiente, não incluem essa variável em seus métodos.

- Algumas propostas de inclusão da variável ambiental nas análises de risco não o fazem de maneira clara, abrangente e de forma a facilitar o seu uso.

- As análises de risco quantitativas, embora úteis, são dispendiosas e necessitam de alguma especialização do técnico responsável pela sua aplicação.

- Algumas técnicas de análise de risco qualitativas, ou semi-quantitativas, atendem perfeitamente às necessidades de avaliação dos riscos ambientais.

- É sempre recomendável a realização da avaliação preliminar de risco, identificando as áreas de classe de risco potencialmente mais alta.

- As técnicas de análise de risco de processo aprimoradas, para contemplar a variável meio ambiente, são perfeitamente aplicáveis e permitem uma clara e rápida identificação do risco, definição das hipóteses de risco e avaliação das consequências ambientais dos acidentes previstos.

- A CATBRAS, modificada para abranger todos os aspectos ambientais necessários à classificação dos riscos ao meio ambiente e à normatização dos termos relativos a cada categoria de risco, permitiu a reclassificação de risco de várias unidades de uma empresa siderúrgica, de maneira rápida e precisa.

- A Análise Preliminar de Risco (APR), modificada em Análise Preliminar de Risco - Ambiental (APR-A) para incluir os efeitos dos eventos sobre o meio ambiente através da apresentação de tipos de danos possíveis, sua extensão e importância do meio afetado e sua importância na determinação da categoria de risco e na necessidade de controle, permitiu uma melhor clareza, abrangência e praticidade de uso.

- As mesmas condições foram obtidas na modificação efetuada para obter a Análise de Árvore de Eventos - Ambiental (AE-A). Nela, foram introduzidos os controles necessários para minimizar ou eliminar os danos de acidentes com efeitos sobre o meio ambiente, e uma definição clara e abrangente das consequências ambientais da realização de um evento indesejável e seus controles.

- A aplicação prática da análise de risco ambiental a uma unidade da empresa utilizada como exemplo evidenciou ter essa unidade (carboquímicos) vários sistemas com alto potencial de risco ambiental, com as seguintes caracteristicas: 1) instaladas nas vizinhanças de uma área de proteção ambiental (manguezal) ou de uso industrial; 2) situada a menos de $500 \mathrm{~m}$ dessas fontes; 3) sem contenção secundária; 4) contendo volumes superiores a 50 litros; 5) região com má dispersão de ventos.

- As modificaçōes efetuadas nas técnicas (CATBRAS, APR e AAE) para conter a variável ambiental, e sua aplicaçăo prática a um processo siderúrgico, abrangendo processos químicos e mecânicos, permitem concluir que as respectivas técnicas propostas (CATBRAS, APR-A e AAE-A) são úteis para avaliar os riscos nesse processo como também podem ser aplicadas a outros segmentos ou setores industriais.

- Considerando os bons resultados obtidos com o uso das técnicas modificadas de avaliação de risco, para incluir a variável ambiental, recomenda-se a sua adoção em futuras análises de risco ambiental de processo siderúrgico ou outros setores industriais.

\section{Sobre a legislaçăo:}

- Embora alguns Estados citem a sua preocupação com a realização do evento de risco, e sugiram a análise de risco, não há uma exigência clara e especifica para sua realização.

- A Resolução CONAMA 01/86, que trata do Estudo de Impacto Ambiental, não menciona a exigência da análise de risco ambiental, para definição de medidas de controle ou de área de implantação de um empreendimento, entre seus quesitos técnicos.

- A Resolução CONAMA 237/97, que regulamenta o processo de licenciamento ambiental, inclui, entre os "estudos ambientais" que podem ser requeridos em qualquer etapa do processo, a análise preliminar de risco. A mesma Resolução não especifica ou esclarece a necessidade de sua exigência.

- O fato de a Resolução $237 / 97$ haver indicado uma técnica de análise de risco delega erroneamente ao agente ambiental competente e ao empreendedor a identificaçăo das 
hipbteses de acidentes, sem haver a preocupação com a avaliação das consequências ambientais do risco identificado.

- Das conclusões obtidas nos itens anteriores, relativas à legislação ambiental federal e estadual para exigência da análise de risco ambiental, recomenda-se:

1. aprimorar a atual legislação federal, $e$ incluir nas legislações estaduais a exigência de ARA, no que se refere ao licenciamento ambiental e EIA/RIMA;

2. definir, nas legislações citadas, a abrangência da ARA, as técnicas disponíveis e os procedimentos para inspecionar sua realização e recomendaçōes;

3. normatizar, através de órgãos e associações ambientais reconhecidas, os métodos e procedimentos para a ARA.

\section{Sobre custos:}

- Embora os custos para realização da ARA possam ser considerados altos, é recomendada a sua execução por empresa especializada.

- Alternativamente, a execução da ARA pode ser feita através de colaboradores treinados, contando com a assessoria de especialistas contratados.

- A execução da ARA por um grupo corporativo, devidamente treinado e experiente, deve ser incentivada.

- Deve-se evitar a execução da ARA por pessoal treinado mas que tenha várias funções dentro da empresa.

\section{Sobre gerenciamento e comunicaçăo de riscos:}

- O conhecimento dos riscos de acidentes de um empreendimento permite elaborar planos de ação, definir recursos e responsabilidades, de forma a obter-se um Programa de Gerenciamento de Risco Ambiental.

- O Programa de Gerenciamento de Risco Ambiental é um instrumento que permite ao empreendedor negociar com autoridades ambientais competentes, companhias seguradoras $\mathrm{e}$ órgãos de financiamento, em condições favoráveis, na busca de soluções que privilegiem a sua empresa.

- As açōes para mitigação, controle ou eliminação dos riscos identificados na ARA dão ao empreendedor e técnicos especializados as ferramentas necessárias para uma eficiente comunicaçāo com os vários segmentos da sociedade, influenciados direta ou indiretamente pelas atividades da empresa.

- O planejamento da comunicaçăo de risco ambiental possibilita à empresa uma adequada troca de informaçōes entre o público interessado e a mesma em situaçסes normais e controladas, e permite uma atuação coerente nas situaçoes de crise que ocorrem quando da efetivação de um evento indesejável. 


\section{REFERÊNCIAS BIBLIOGRÁFICAS}

ABSY, M.L.; ASSUNÇÃO, F.N.A.; FARIA, S.C. et al. Avaliação de impacto ambiental: agentes sociais, procedimentos e ferramentas. IBAMA, Instituto Brasileiro do Meio Ambiente e dos Recursos Naturais Renováveis. Brasilia, DF, 1995, $134 \mathrm{p}$.

ALLENBY, B.R. Industrial ecology and comprehensive risk assessment (Chap. 17). In: KOLLURU, R.V.; BARTELL, S.M.; PITBLADO, R.M. \& STRICOFF, R.S. (Eds.). Risk Assessment and Management Handbook for Environmental, Health, and Safety Professionals. McGraw-Hill, Inc., New York, 1996.

ANTOINE, J. Les études de danger dans la siderurgie française. Laboratoire d'étude et de controle de l'environnement siderurgique - LECES, RE/L.69, June 1988, 7 p. +1 fig.

ATLAS (Editora). Manuais de Legislaçăo Atlas - Segurança e Medicina do Trabalho. S. Paulo, Equipe Atlas/ Editora Atlas S.A., $38^{\mathrm{a}}$ edição, 1997, 517 p.

BARNTHOUSE, L.W. The role of models in ecological risk assessment: a 1990's perspective. Environmental Toxicology and Chemistry, 11:1751-1760, 1992.

BARNTHOUSE, L.W. Issues in ecological risk assessment: the CRAM perspective. Risk Analysis, 14 (3) : 251-256, 1994.

BARTELL, S.M. Ecological/environmental risk assessment - principles and practices (Chap. 10). In: KOLLURU, R.V.; BARTELL, S.M.; PITBLADO, R.M. \& STRICOFF, R.S. (Eds.). Risk Assessment and Management Handbook for Environmental, Health, and Safety Professionals. McGraw-Hill, Inc., New York, 1996.

BERTOLETTI, E.; GHERARD-GOLDSTEIN, E.; NIPPER, M.G. Toxicidade de águas superficiais na região da Grande São Paulo. Rev. Soc. Bras. Toxicol, 2 (2) : 1-20, 1989.

BRAÑES, R. Institutional and legal aspects of the environment in Latin America, including the participation of non-governmental organizations in environmental management. Interamerican Development Bank, Washington, DC, 1991, 128 p.

BRITISH STANDARD SPECIFICATION FOR ENVIRONMENTAL MANAGEMENT SYSTEMS. BS 7750:199, 1992.

CALABRESE, E.J. \& KENYON, E.M. Air Toxics and Risk Assessment. Lewis Publishers, Inc., Michigan, USA, 1991, 662p.

CANTER, L.W. Case study showing the use of EIA methods. 12th International Seminar on Environmental Assessment and Management, 7-20 July 1991. University of Aberdeen, Scotland, UK (organized by the Centre for Environmental Management and Planning CEMP).

CARVALHO FILHO, C.M.; VEIGA, W.; PEREIRA, N.; CAVALCANTI, A.R. O controle do meio ambiente na COSIPA. Simpósio de Controle Ambiental na Siderurgia, 2. Vitória, ES, novembro/87. IBS, Instituto Brasileiro de Siderurgia, Comissão de Assuntos Ambientais, 1987, p. Q1-Q40.

CCPS, Center for Chemical Process Safety. Guidelines for Hazard Evaluation Procedures. American Institute of Chemical Engineers, New York, 1985.

CETESB, Companhia de Tecnologia de Saneamento Ambiental. Poluiçăo das Águas no Estuário e Baía de Santos. S. Paulo, CETESB, 1978. Vols. I-II. 
CETESB, Companhia de Tecnologia de Saneamento Ambiental. Técnicas de Análise de Risco. S. Paulo, CETESB/PROCOP, 1988, s/p. (apostila de curso de treinamento).

CETESB, Companhia de Tecnologia de Saneamento Ambiental. Relatório de Qualidade das Águas Interiores do Estado de Săo Paulo - 1995. São Paulo, CETESB, 1996. Série Relatórios, $285 \mathrm{p}$.

CONAMA, Conselho Nacional do Meio Ambiente. Resolução CONAMA $n^{\circ}$ 01, de 23.02.86. D.O.U. de 17.02.86. In: Resoluçסes CONAMA 1984-86. Brasília, SEMA, p. 33-38, 1986a.

CONAMA, Conselho Nacional do Meio Ambiente. Resolução CONAMA $n^{\circ}$ 20, de 18.06.86. D.O.U. de 30.07.86. In: Resoluçסes CONAMA 1984-86. Brasília, SEMA, p. 72-89, 1986b.

CONAMA, Conselho Nacional do Meio Ambiente. Resolução CONAMA n 237, de 19.12.97.

CONWAY, R.A. Introduction to environmental risk analysis, p,. 1-30. In: CONWAY, R.A. (Ed.) Environmental Risk Analysys for Chemicals. Van Nostrand Reinhold Co., N.Y., 1982, $558 \mathrm{p}$.

CORSEUIL, H.X. \& MARINS, M.D.M. Contaminação de águas subterrâneas por derramamentos de gasolina: o problema é grave? Eng. Sanit. Amb. 2 (2) : 50-54, 1997.

COSIPA, Companhia Siderúrgica Paulista. (Documento institucional sobre a empresa, s/data).

COSTA JR., P.J. \& GREGORI, G. Direito Penal Ecologico. S. Paulo, CETESB, 1981, 96 p.

COVELLO, V.T. Communicating risk in crisis and noncrisis situations (Chap. 15). In: KOLLURU, R.V.; BARTELL, S.M.; PITBLADO, R.M. \& STRICOFF, R.S. (Eds.). Risk Assessment and Management Handbook for Environmental, Health, and Safety Professionals. McGraw-Hill, Inc., New York, 1996.

COVELLO, V.T.; KAWAMURA, K.; BOROUSH, M.; IKEDA, S.; LYNES, P.F.; MINOR, M.S. Cooperation versus confrontation: a comparison of approaches to environmental risk management in Japan and the United States. Risk Analysis 8 (2) : 247-260, 1988.

CUSTÓDIO, H.B. Responsabilidade civil por danos ao meio ambiente. Universidade de S. Paulo, Faculdade de Direito, Departamento de Direito Civil. Tese de Livre-Docência, $1983,307 \mathrm{p}$.

DE CICCO, M.G.A.F. \& FANTAZZINI M.L. Técnicas modernas de geréncia de riscos. São Paulo, IBGR (Instituto Brasileiro de Gerenciamento de Risco), 1985, 181 p.

DE MARCHI, B. The Seveso directive: an Italian pilot study in enabling communication. Risk Analysis, 11 (2) : 207-215, 1991.

DEPARTMENT OF DEFENSE, MILITARY STANDARD SYSTEM SAFETY PROGRAM REQUIREMENTS, MIL-STD-8828. Washington, DC, 1984

DITZ, D. RANGANATHAN, J. BANKS, R.D. Environmental accounting: an overview, p. 1-46. In Green ledges: Case studies in corporate environmental accounting. World Resources Institute Book. 1995, 181p.

EPSTEIN, M.J. Measuring corporate environmental performance - Best practices for costing and managing an effective environmental strategy. Irwin Professional Publ., Chicago, 1996, 319p.

ESCARITO, A.F. Política Nacional de Meio Ambiente no Paraguai. In: Politicas Ambientais no Mercosul e as Experiencias de Integração Européia. Centro de Estudos Konrad Adenauer Stiftung, Série Debates, $n^{\circ} 8,1995$. 
ESCHENROEDER, A.Q. \& FAEDER, E.J. A Monte Carlo analysis of health risks from PCB: contaminated mineral oil transformer fires. Risk Analysis, 8 (2) : 291-297, 1988.

FANTAZZINI, M L. \& DE CICCO, F. Introdução à Engenharia de Segurança de Sistemas. S. Paulo, FUNDACENTRO, 1985.

FANTAZZINI, M.\& FARBER, J.H. Análise de riscos voltada ao meio ambiente. Geréncia de Risco, IBGR, nov/dez $1989: 42-43$.

FARBER, J.H. Técnicas de análise de riscos e os acidentes maiores. Gerencia de Risco, $1^{\circ}$ trim, $1991: 30-35$.

FERNíCOLA, N. D. Perigo e risco. Conceitos básicos. Congresso Latino-Americano de Toxicologia, 8; Congresso de Toxicologia do Cone Sul, 1. Porto Alegre, RS, 29 a 31.10.92. Anais. s/p.

FINOL, E.C. Ley penal del ambiente y sus normas tecnicas. MARNR, Venezuela, 1992, 478 p.

FOSTER, S. \& HIRATA, R. Determinação do risco de contaminaçăo das águas subterrâneas um método baseado em dados existentes. S. Paulo/Instituto Geológico, Bol. 10,1993,92p.

GOOSSENS, L.H.J. Risk prevention and policy-making in automatic systems. Risk Analysis, $11(2): 217-228,1991$.

GOYAL, R.K. \& AL-JURASHI, N.M. Gas dispersion models. Professional Safety, May 1990 : 23$32,1990$.

GREIG-SMITH, P.W. A European perspective on ecological risk assessment, illustrated by pesticide registration procedures in the United Kingdom. Environmental Toxicology and Chemistry, 11:1673-1689, 1992.

HERY, M.; DIEBOLD. F.; HECHT, G. Exposure of contractors to chemical pollutants during the maintenance shut-down of a chemical plant. Risk Analysis, 16 (5) : 645-656, 1996.

HUBERT, P.; BARNY, M.H.; MOATTI, J.P. Elicitation of decision-makers' preferences for management of major hazards. Risk Analysis, 11 (2) : 199-206, 1991.

IDB, Interamerican Development Bank. Guide for Assessing the Environmental Impact of Thermoeletric Stations. Latin American Energy Organization/IDB, Quito, Ecuador, April 1994. 1994 a, $237 \mathrm{p}$.

IDB, Interamerican Development Bank. Guide for Assessing the Environmental Impact of Hydropower Stations. Latin American Energy Organization/IDB, Quito, Ecuador, November 1994. 1994b, $161 \mathrm{p}$.

IDB, Interamerican Development Bank. Guide for Assessing the Environmental Impact of Biomass Developments for Energy Purposes. Latin American Energy Organization/IDB, Quito, Ecuador, November 1994. 1994c, 251 p.

IISI, International Iron and Steel Institute. Environmental Aspects in the Iron and Steel Industry, IISI, 1987.

IRPTC/UNEP. English /Russian glossary of selected terms in preventive toxicology. Moscow,1982 In: EURO/WHO. EURO Reports and Studies $n^{\circ} 100$. Health and the Environment. Report on a WHO meeting. Viena, 12-16 December,1983. World Health Organizations/Regional Office for Europe, Copenhagen, 1986. [em: Fernícola, 1992] 
ITII, The International Technical Information Institute (ed.). Toxic and Hazardous. The International Technical Information Institute, Tokyo, Japan, 1981, 650 p.

ITSEMAP, Instituto Tecnológico MAPFRE de Segurança e Engenharia Ambiental. Análise de Riscos de Processos. ITSEMAP, 1992, 150 p. (apostila de curso de treinamento).

IUPAC, International Union on...and Applied Chemistry. Glossary of terms used in toxicology. Draft. International Union of Pure and Applied Chemistry. Scotland,1991.

JISF, Japan Iron and Steel Federation. The Steel Industry. JISF, October 1989.

JOURDAN, L. Des accidents de Flixborough et Seveso à l'elaboration d'une directive communautaire. Annales des Mines, 10-11: 88-93, 1986.

KASTENBERG, W.E \& SOLOMON, K.A. On the use of confidence levels in risk management. J. Hazardous Materials, 10:263-78, 1985.

KAYES, P.J. (ED.). Manual of Industrial Hazard Assessment Techniques. October 1985 (preparado em cooperação com o Banco Mundial, por: Technical Ltd., London, England). 1985, 99 p. + apêndices.

KENDALL, R.J. \& AKERMAN, J. Terrestrial wildlife exposed to agrochemicals: na ecological risk assessment perspective. Environ. Toxicol. Chem. 11: 1727-1749, 1992.

KOLLURU, R.V. Risk Assessment and Management - A Unified Approach. In: KOLLURU, R.V.; BARTELL, S.M.; PITBLADO, R.M. \& STRICOFF, R.S. (Eds.). Risk Assessment and Management Handbook for Environmental, Health, and Safety Professionals. McGrawHill, Inc., New York, 1996.

LANDRUM, P.F.; LEE II, H., LYDY, M.J. Toxicokinetics in aquatic systems: model comparisons and use in hazard assessment. Environ. Toxicol. Chem. $11: 1709-1725$, 1992.

LE SAUX, A. L'étude globale des sites industriels. Annales des Mines, oct-Nov. $1986: 29-37$, 1986.

LEES, F.P. Loss prevention in the process industries. Vol. I. England, Butterworth \& Co. Publi., $1980,670 \mathrm{p}$.

MAEVE, R. Environmental cost accounting. (Draft 3, ALCOA, 1994. Não publicado).

MAINI, M.N. Política Nacional de Meio Ambiente na Argentina. In: Politicas Ambientais no Mercosul e as Experiências de Integração Européia. Centro de Estudos Konrad Adenauer Stiftung, Série Debates, $n^{\circ}$ 8, 1995.

MAKARON, O.M.S de M. Metodologia para classificação, análise, avaliação e gerenciamento dos riscos de fontes e atividades potencialmente geradoras de acidentes ambientais CATBRAS. S. Paulo, CETESB, 1992 (apostila de curso de treinamento; não publicado).

MANSOT, J. La législation et la prévention du risque dans l'industrie chimique: une expérience régionale. Annales des Mines, 10-11:94-102, 1986.

MARTIN, G.J. Le dommage écologique dans la communauté européenne. Conferência Internacional de Direito Ambiental. Rio de Janeiro, RJ (Brasil), outubro de 1991. Anais, p. 301-306.

MASSAD, E. Modelling the effects of air pollution on the susceptibility to respiratory infections. Ecological Modelling, $52: 21-28,1990$. 
MILARÉ, E. \& BENJAMIN, A. H.V. Estudo Prévio de Impacto Ambiental: teoria, prática e legislaçåo. São Paulo: Editora Revista dos Tribunais, 245 pp. 1993.

MÖLLER, L.; LAX, I.; TORNDAL, U.B.; ERIKSSON, L.C. Risk assessment of nitrated polycyclic aromatic hydrocarbons. Risk Analysis, 13 (3) : 291-299, 1993.

MONTEIRO, A.J.L.C. Direito Ambiental (texto de palestra ministrada no Curso de Gestão Ambiental, MBV Consultores Associados, 1996 - não publicado).

NAVAS-PEREIRA, D.; PÁDUA, H.B.; EYSINK, G.G.J.; PIVA-BERTOLETTI, S.A.E. Níveis de contaminação por metais pesados e pesticidas na água, sedimento e peixes da represa de Barra Bonita. Congresso Brasileiro de Engenharia Sanitária e Ambiental, 13. Maceió, $\mathrm{AL}$, agosto de $1985 ; \mathrm{n}^{\circ} 87,21 \mathrm{p}$.

NORTON, S.B.; RODIER, D.J.; GENTILE, J.H.; VAN DER SCHALIE, W.H.; WOOD, W.P.; SLIMAK, M.W. A framework for ecological risk assessment at the EPA. Environmental Toxicology and Chemistry, $11:$ 1663-1672, 1992.

OIT, OFICINA INTERNACIONAL DEL TRABAJO, GINEBRA. Los desastres industriales y su prevención, hoy. Cap. 1. In: OIT, Prevención de desastres industriales. Informe V (1) para la Conferencia Internacional del Trabajo de 1992. Genebra, Suiça, 10 p.

OLIVEIRA, L. P. M. Gerência de risco como administração. Seguros e Riscos, Ano $1 n^{\circ} 2$, julho de 1986, s/p.

OMS, Organização Mundial da Saúde. Comissión Preparatoria de la Conferencia de las Naciones Unidas sobre el Medio Ambiente. Organización Mundial de la Salud, 1978.

PARMEGGIANI, L. (ed.). Encyclopaedia of Occupational Health and Safety. ILO, Genebra, Suiça, 1983, $2444 \mathrm{p}$.

PEREIRA. N. Eutrofização no sistema estuarino e das baías de Santos e Săo Vicente (Estado de Săo Paulo, Brasil). Universidade de S. Paulo, Faculdade de Saúde Pública. Dissertação de Mestrado, 1985, 2 vols.

PEREIRA, N.; SOUZA, H.G.; VILAVERDE, R.A.B. EIA/RIMA - a experiência da COSIPA. Simpósio sobre Controle Ambiental na Siderurgia, V. IBS, Belo Horizonte, MG, outubro de 1991, $23 p$.

PEREIRA, N. \& PEDRO, L.C.F. Análise de riscos de processo. (Apostila para treinamento interno - Grupo de trabalho para elaboração do Programa de Gerenciamento de Riscos da COSIPA - setembro de 1992, s/p. - não publicado).

PEREIRA, N. \& PEDRO, L.C.F. Classificação quanto ao potencial de risco de algumas unidades da COSIPA, segundo método "CATBRAS". Simpósio sobre Controle Ambiental na Siderurgia, 6. IBS, S. Paulo, SP, junho de 1993. IV-2, 20p.

PHILIPSON, L.L \& NAPADENSKY, H.S. The methodology of hazardous materials transportation risk assessment. J. Hazardous Materials, 6: 361-82, 1982.

PORTO, M.F.S. \& FREITAS, C.M. Major chemical accidents in industrializing countries: the socio-political amplification of risk. Risk Analysis 16 (1) : 19-30, 1996.

PROCTOR, N.H.; HUGHES, J.P.; FISCHMAN, M.L. (eds.). Chemical Hazards of the Workplace. Van Nostrand Reinhold, San Francisco, CA (USA), 1988, 573 p.

PRÓSPERI, V.A. Aplicaçăo de testes de toxicidade com organismos marinhos para a análise de efluentes industriais lançados em áreas estuarinas. Universidade de S. Paulo, Escola de Engenharia de S. Carlos, 1993. Dissertação de Mestrado, 120 p. 
RASMUSSEN, J. \& BATSTONE, R. Why do complex organizational systems fail? The World Bank, Policy Planning and Research Staff, Environment Department. Environment Working Paper No. 20, 1989, 39p.

RICCI, P.F \& CIRILLO, M.C. Uncertainty in health risk analisys. J. Hazardous Materials, 10 : 433-47, 1985.

RITTER, D. The need for risk assessment legislation. Risk Analysis 8 (2) : 169-170, 1988.

RODRIGUES, J.R. Criterios Ambientais para o ordenamento territorial de fontes de poluiçăo. Universidade de S. Paulo, Faculdade de Saúde Pública, Departamento de Saúde Ambiental, 1990. Dissertação de Mestrado, 120 p. + anexos.

ROSE, J.B. Risk assessment techniques to determine standards and treatment. In: Workshop sobre Biologia Molecular e Análise de Riscos: Novos Avanços em Microbiologia Ambiental. CNPq/FAPESP (patroc.); Depto. de Microbiologia - ICB/USP, SBM (org.). S. Paulo, SP, agosto de 1994, s/p.

RUBIO, R. R. M. Curva de perigo: uma forma de gerenciar riscos. Manutençåo, nov/dez 92: 16-19, 1992.

SANTOS, S.L. Risk assessment - a tool for risk management. Environ. Sci. Technol. 21 : 239240, 1987.

SANTOS, S.L. Developing a risk communication strategy. Jour. AWWA, nov/90: 45-49, 1990.

SANTOS, S.L. Risk management: the ultimate objective. Petroleum Today, 2 (1), 1991, s/p.

SANTOS, S.L.; COVELLO, V.T.; MCCALLUM, D.B. Industry response to SARA Title III: pollution prevention, risk reduction, and risk communication. Risk Analysis, 16 (1) : 57-66, 1996.

SAX, N.I. Dangerous Properties of Industrial Materials. Van Nostrand Reinhold, NY (USA), $1984,3124 \mathrm{p}$.

SHOWALTER, P.S. \& MYERS, M.F. Natural disasters in the United States as release agents of oil, chemicals, or radiological materials between 1980-1989: analysis and recommendations. Risk Analysis, 14 (2) : 169-182, 1994.

SILANO, V. Evaluacion de riesgos para la salud publica asociados con accidentes causados por agentes quimicos. Centro Panamericano de Ecologia Humana y Salud (ECO), OPAS, OMS, 1984. 89p.

SILVEIRA, M.A.V.; PEREIRA, N.; TOMMASI, L.R. Resultados preliminares sobre os teores de detergentes aniônicos na baia e estuário de Santos. Bolm Inst. oceanogr., S Paulo, 31 (2) : 95-99, 1982.

SIMON, Z. Introdução à análise de risco ambiental para contaminantes. Acta Toxicologica, Pelotas, Centro de Estudos de Toxicologia, 6/7: 51-85, 1983/1984.

STALLEN, P.J.M. \& TOMAS, A. Public concern about industrial hazards. Risk Analysis, 8 (2) : 237-245, 1988.

STRICOFF, R.S. Safety risk analysis and process safety management - principles and practices. Chap. 8. In KOLLURU, R.V.; BARTELL, S.M.; PITBLADO, R.M. \& STRICOFF, R.S. (Eds.). Risk Assessment and Management Handbook for Environmental, Health, and Safety Professionals. McGraw-Hill, Inc., New York, 1996. 
SUTER II, G.W.; CORNABY, B.W.; HADDEN, C.T.; HULL, R.N.; ATACK, M.; ZAFRAN, F.A. An approach for balancing health and ecological risks at hazardous waste sites. Risl Analysis, 15 (2) : 221-232, 1995.

TOMMASI, L.R. Consideraçס̃es ecológicas sobre o sistema estuarino de Santos (SP). Universidade de São Paulo, Instituto Oceanográfico. Tese de Livre-Docência, 1979, 2 vols, $489 \mathrm{p}$.

TRAUMANN, T. O valor do verde. Revista Veja, 04 de junho de $1997:$ 80-81, 1997.

TRAVIS, C.C. \& MORRIS, J.M. The emergence of ecological risk assessment. Risk Analysis, $12(2): 167-168,1992$.

UNEP, United Nations Environment Programme. Guidelines for Environmental Management of Iron and Steel Works. UNEP - Industry \& Environment Guidelines Series, ISBN 92807 $1113 \mathrm{X}, 1986 \mathrm{a} .77 \mathrm{p}$.

UNEP, United Nations Environment Programme. Guidelines on Risk Management and Accident Prevention in the Chemical Industry. UNEP - Industry \& Environment Guidelines Series, ISBN 928071058 3, 1986b, $52 \mathrm{p}$.

USEPA, U.S. ENVIRONMENT PROTECTION AGENCY. A framework for ecological risk assessment. EPA 630/R-92-001. Risk Assessment Forum, Washington,DC., 1992.

USNRC, United States National Research Council. Issues in Ecological Risk Analysis - Ecological Risk Assessment. Vol. 3. National Academic Press, Washington, DC, 1992, 325 p.

VARGAS-BOLDRINI, C. \& NAVAS-PEREIRA, D. Metais pesados na baía de Santos e estuários de Santos e São Vicente - Bioacumulação. Ambiente, Rev. CETESB de Tecnol., 1 (3) : 118$127,1987$.

VARGAS-BOLDRINI, C.; EYSINK, G.G.J.; MARTINS, M.C.; LAMPARELLI, M.C. Contaminantes na bacia do rio Cubatăo e seus reflexos na biota aquática. S. Paulo, CETESB, 1990. Relatório Técnico, 81 p. + anexos.

VAUGHAN, W.J. \& ARDILA, S. Economic analysis of the environmental aspects of investment projects. Inter-American Development Bank, Working Paper ENP100, 1993, 35p.

WHYTE, A.V. \& BURTON, I. Environmental Risk Assessment. III International Council of Scientific Unions. Scientific Committee on Problems of the Environment (SCOPE). SCOPE 15. John Wiley \& Sons Publ., 1980, $159 \mathrm{p}$.

YOSHIDA, M. Management of environmental control in the Japanese steel industry, p. 27- 57. In: IISI, International Iron and Steel Institute (ed.), Environmental Control in the Steel Industry. Papers prepared for the 1991 ENCOSTEEL World Conference (Germany), 1992, $625 \mathrm{p}$.

ZAGATTO, P.A. \& GHERARDI-GOLDSTEIN, E. Toxicidade em águas do Estado de São Paulo. Ambiente, Rev. CETESB de Tecnol., 5 (1) : 13-20, 1991.

ZÓBOLI, J.G. Política Nacional de Meio Ambiente no Uruguai. In: Políticas Ambientais no Mercosul e as Experiencias de Integraçăo Européia. Centro de Estudos Konrad Adenauer Stiftung, Série Debates, $n^{\circ} 8,1995$. 